Lana Beth Ayres Franco de Araujo

\title{
O processo de publicação de obras literárias
}

traduzidas

\section{Tese de Doutorado}

Tese apresentada como requisito parcial para obtenção do grau de Doutor em Estudos da Linguagem/Letras pelo Programa de Pós-graduação em Estudos da Linguagem, do Departamento de Letras da PUC-Rio.

Orientadora: Profa Marcia do Amaral Peixoto Martins

Rio de Janeiro

Junho de 2020 


\section{Lana Beth Ayres Franco de Araujo}

\section{O processo de publicação de obras literárias traduzidas}

Tese apresentada como requisito parcial para a obtenção do grau de Doutor pelo Programa de Pósgraduação em Estudos da Linguagem da PUC-Rio. Aprovada pela Comissão Examinadora abaixo:

Prof $^{\mathrm{a}}$ Marcia do Amaral Peixoto Martins

Orientadora e Presidente Departamento de Letras - PUC-Rio

Prof. Paulo Fernando Henriques Britto Departamento de Letras - PUC-Rio

Profa. Teresa Dias Carneiro Departamento de Letras - PUC-Rio

Profa. Giovana Cordeiro Campos de Mello UFF

Prof. Lauro Maia Amorim

Universidade Estadual Paulista Júlio de Mesquita Filho 
Todos os direitos reservados. É proibida a reprodução total ou parcial do trabalho sem autorização da universidade, da autora e da orientadora.

\section{Lana Beth Ayres Franco de Araujo}

Licenciada em Português/Literaturas pela Universidade Federal do Rio de Janeiro (UFRJ) desde 1985. Graduou-se em Letras Inglês/Literaturas pela Universidade do Estado do Rio de Janeiro (UERJ), em 2006. Mestre em Literaturas de Língua Inglesa (UERJ), em 2014. É assistente técnico legislativo na Câmara Municipal do Rio de Janeiro desde 1982.

Ficha Catalográfica

Araujo, Lana Beth Ayres Franco de

O processo de publicação de obras literárias traduzidas / Lana Beth Ayres Franco de Araujo; orientadora: Marcia do Amaral Peixoto Martins. - Rio de Janeiro: Departamento de Letras, 2020.

255 f,: il.; $29,7 \mathrm{~cm}$

1.Tese (doutorado) - Pontifícia Universidade Católica do Rio de Janeiro, Departamento de Letras.

Inclui referências bibliográficas.

1. Letras - Teses. 2. [Literatura traduzida]. 3. [Cultura tradutora]. 4. [Sociologia da tradução]. 5. [Mercado editorial]. I. Martins, Marcia A. P. II. Pontifícia Universidade Católica do Rio de Janeiro. Departamento de Letras. III. Título. 
Para a minha filha Maria Eduarda, minha zelosa companheira de todas as horas. 
À memória

de minha tia Maria Fernanda, que me conduziu ao mundo dos livros,

de meus pais, Paulo e Zélia, e de minha avó Delfina, leitores contumazes,

de meu amado Kleber, grande incentivador dos meus estudos. 


\section{Agradecimentos}

Desejo agradecer a muitas pessoas que tornaram este trabalho possível:

A meus Professores e colegas da PUC, em especial,

A Irma Caputo, pela parceria e pelo apoio incondicional, ajudando-me a superar dificuldades de toda sorte.

A Renata Pettengill, por ter viabilizado praticamente todas as entrevistas realizadas.

Aos Professores Paulo Henriques Britto, Lauro Maia Amorim e Giovana Cordeiro Campos de Mello, pelas sugestões cruciais para o desenvolvimento de minha pesquisa feitas no Exame de Qualificação.

Aos Professores Paulo Henriques Britto, Lauro Maia Amorim, Giovana Cordeiro Campos de Mello e Teresa Dias Carneiro, por terem aceito o convite para integrar a banca.

Às professoras Janine Pimentel e Marcela Iochem Valente, por terem aceito integrar a banca como suplentes.

À Vice-Reitoria Acadêmica da PUC-Rio, pela isenção de taxas acadêmicas e por todo o suporte acadêmico e administrativo.

À Secretaria do Departamento de Letras, em especial a Francisca Ferreira de Oliveira, querida Chiquinha.

E agradeço, sobretudo, à minha orientadora Professora Marcia do Amaral Peixoto Martins, por todo o suporte ao longo do processo em que se desenvolveu a minha pesquisa, apoio que transcendeu a seara acadêmica, estando ao meu lado em um dos momentos mais sensíveis de minha vida.

O presente trabalho foi realizado com apoio da Coordenação de Aperfeiçoamento de Pessoal de Nível Superior - Brasil (CAPES) - Código de Financiamento 001. 


\section{Resumo}

Araujo, Lana Beth Ayres Franco de; Martins, Marcia do Amaral Peixoto (Orientadora). O processo de publicação de obras literárias traduzidas. Rio de Janeiro, 2020. 255p. Tese de Doutorado - Departamento de Letras, Pontifícia Universidade Católica do Rio de Janeiro.

A presente tese investiga o processo de seleção, tradução e publicação de obras literárias estrangeiras, tendo por campo de observação o Grupo Editorial Record, que figura, assim, como representante da indústria editorial brasileira. A motivação para este estudo foi o fato de que, ao comprar um livro traduzido, os leitores/consumidores, de um modo geral, não se dão conta das muitas etapas que culminaram no produto que estão levando para casa. O foco desta pesquisa, portanto, volta-se para a sequência de operações que se perfaz obedecendo, via de regra, à seguinte ordem cronológica: a seleção da obra a ser traduzida e a subsequente aquisição de seus direitos autorais; a escolha do tradutor e do copidesque, agentes que, respectivamente, traduzem para a língua alvo o texto estrangeiro e aprimoram o texto já traduzido; a escolha da capa e do título da obra já vertida para o vernáculo; as estratégias de divulgação e de distribuição da obra traduzida; por fim, a recepção dessa obra por parte da crítica e do leitor comum. O objetivo do presente estudo é, portanto, discutir e analisar a rede de agentes e atividades que é promovida e articulada pela indústria editorial brasileira com vistas a confeccionar um bem de consumo possuidor de características e finalidade próprias, que são as obras literárias traduzidas, destinadas à leitura feita nas horas de lazer. Levando-se em conta o expressivo número de obras traduzidas publicadas aqui, pode-se considerar o Brasil como uma cultura tradutora. Em contrapartida, culturas hegemônicas como a norte-americana e a britânica, de um modo geral, traduzem menos, ou seja, importam menos literatura para a tradução, sendo, ao contrário, mais traduzidas, visto que exportam mais suas produções literárias. No que tange ao aporte teórico, o meu estudo se sustenta basicamente nos seguintes pilares: 1) a concepção da literatura como polissistema, desenvolvida por Itamar Even-Zohar; 2) o entendimento da tradução como fenômeno da cultura tradutora, de Gideon Toury; 3) os conceitos de reescrita e de patronagem, propostos por André Lefevere; 4) a visão de tradução como agente formador das literaturas nacionais, promovida por Lawrence Venuti; 5) as abordagens de orientação sociológica propriamente dita, que trazem nomes como Michaela Wolf, Pascale Casanova, Daniel Simeoni, Maria Timoczko, Johan Heilbron, dentre outros. Com base na leitura da bibliografa selecionada e na análise dos dados gerados pelas entrevistas realizadas, é possível concluir que a tradução, tradicional e frequentemente examinada do ponto de vista linguístico, pode ser analisada também sob uma perspectiva mercadológica, sendo considerada, dessa forma, como um produto comercial elaborado para atender à demanda de um nicho da indústria do entretenimento. Assim sendo, por provocar toda uma malha de tarefas executadas por profissionais que concorrem para a manufatura de um produto destinado a um público consumidor específico, parece legítimo concluir que a tradução consiste numa prática social, uma vez que promove a atuação de profissionais não só do campo editorial, mas, particularmente, de profissionais do texto, como o tradutor.

\section{Palavras-chave}

Literatura traduzida; cultura tradutora; sociologia da tradução; mercado editorial. 


\section{Abstract}

Araujo, Lana Beth Ayres Franco de; Martins, Marcia do Amaral Peixoto (Advisor). The Process of Publishing Literary Works. Rio de Janeiro, 2020. 255p. Tese de Doutorado - Departamento de Letras, Pontifícia Universidade Católica do Rio de Janeiro.

The present dissertation investigates the process of selecting, translating and publishing foreign literary works, with special focus on the publishing house Grupo Editorial Record, which thus represents the Brazilian publishing industry. The motivation for this study was the fact that, when buying a translated book, readers/consumers, in general, are not aware of the many stages which resulted in the product they are taking home. So this research focuses on the sequence of actions which usually unfold in the following order: the selection of the literary work to be translated and the subsequent acquisition of its copyright; the selection of the translator and the copy editor, agents who, respectively, translate the foreign text into the target language and improve the translated version; the choice of the cover and the title of the book already translated into the target language; the strategies for advertising and distributing the translated book; and lastly, the reception of this book by the literary critics and the average readership. The object of this study is thus the net of agents and activities which is promoted and articulated by the Brazilian publishing industry aiming at manufacturing a consumer good with features and purposes of its own, which are the translated literary works destined for leisure reading. Taking into account the expressive number of translated literary works published here, Brazil can be regarded as a translating culture. In contrast, hegemonic cultures such as the North American and the British ones, in general, translate less, that is, import fewer literary works for translation, being more translated instead, as they export their literary production more often. Concerning the theoretical framework here used as reference, my study is based on the following pillars: 1) the notion of literature as a polysystem, developed by Itamar Even-Zohar; 2) the understanding of translation as a phenomenon of the translating culture, by Gideon Toury; 3) the concepts of rewriting and patronage, proposed by André Lefevere; 4) the view of translation as the agent of national literature formation, promoted by Lawrence Venuti; 5) the sociologicallyoriented approaches in their own right, whose prominent names are Michaela Wolf, Pascale Casanova, Daniel Simeoni, Maria Timoczko, Johan Heilbron, among others. Based on the selected bibliography and on the analysis of the data generated by the interviews carried out, it is possible to conclude that translation, traditionally and frequently examined under a linguistic viewpoint, can be also analysed under a marketdriven perspective, being thus regarded as a commercial good produced to fulfill the demands of a niche of the entertainment industry. Hence, for triggering a wide range of tasks undertaken by professionals who work so as to make the product aimed at a specific group of consumers, it seems legitimate to infer that translation is a social practice, since it promotes the action of professionals not only those belonging to the publishing field, but, particularly, of text professionals such as translators.

\section{Keywords}

Translated literature; translating culture; sociology of translation; publishing market. 


\section{Sumário}

$\begin{array}{ll}\text { Introdução } & 11\end{array}$

1. Fundamentação Teórica e Metodologia $\quad 18$

1.1. A literatura traduzida como sistema integrado ao polissistema literário nacional: o modelo sistêmico de Itamar Even-Zohar

1.2. A tradução como fenômeno da cultura tradutora: os estudos descritivos de Gideon Toury

1.3. O conceito de patronagem e o poder manipulador das reescritas: a proposta teórica de André Lefevere

1.4. A tradução como agente formador de identidades culturais: o poder político da tradução, como propõe Lawrence Venuti

1.5.1. A contribuição do pensamento de Pierre Bourdieu, Bruno Latour/Michel Callon e Niklas Luhman para uma sociologia da tradução

1.5.2. Os "conceitos-ponte" de Andrew Chesterman

1.6. O campo editorial: uma perspectiva pragmática da tradução como prática social

2. A pré-produção: do autor estrangeiro à editora inserida na cultura tradutora

3. A produção (fase 1): o papel do tradutor na cadeia editorial

4. A produção (fase 2): copidesques (preparadores de originais), revisores, designers de capa e outros agentes

5. A pós-produção: distribuição, o papel das livrarias e dos livreiros, recepção em geral (resenhas, fortuna crítica) na chegada do livro traduzido aos leitores

Considerações finais

Referências

176

ANEXO A

ANEXO B 
ANEXO G 189

ANEXO H

ANEXO I

ANEXO J

224

ANEXO K

229

ANEXO L 233

ANEXO M 235

ANEXO N 245

ANEXO O 251

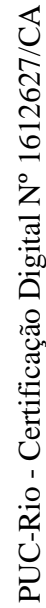




\section{Introdução}

Ao comprar um livro traduzido, o consumidor/leitor, de um modo geral, não se dá conta do processo que culminou no produto que ele está levando para casa. Decerto, esse consumidor/leitor desconhece - ou sequer imagina que existam - os critérios que levaram a editora a escolher aquele título e não outro qualquer. Esse mesmo indivíduo não questiona o que levaria uma editora a publicar no Brasil um romance que tem como protagonista um astro fictício do beisebol, por exemplo. Será que o livro teria vendagem num país em que essa prática esportiva não é popular? Tampouco o leitor de obras traduzidas observa o nome do profissional que possibilitou a leitura de um texto originalmente escrito num idioma que ele, leitor, não domina. Muito dificilmente, vai-lhe ocorrer que aquele texto, depois de traduzido, passou pelas mãos de um revisor, profissional da cadeia tradutória/editorial ainda mais invisível do que o tradutor. Caso conheça a capa que apresenta a versão original, será que terá a curiosidade de verificar, se for o caso, o que levou a editora brasileira a conceber um novo "cartão de visitas" para a cultura tradutora? E será que o exemplar traduzido comprado por esse leitor/consumidor contém paratextos tais como notas, prefácio, posfácio, introdução de autoria do tradutor? Em caso afirmativo, teriam sido dados ao tradutor os devidos créditos? O fato é que a produção de livros traduzidos está tão arraigada às práticas editoriais realizadas no Brasil que talvez o leitor até tenha a ilusão de estar lendo o texto de origem, e não uma versão elaborada por alguém que reescreveu aquele texto produzido primariamente em outra língua.

Uma das atividades mais antigas do mundo, cuja história se confunde com a trajetória da própria humanidade, a tradução, entendida aqui lato sensu como “ponte entre línguas e culturas diferentes”, vem historicamente se revelando como a mais importante ferramenta de aproximação dos povos. Ao se debruçarem sobre essa ferramenta, porém, estudiosos vêm, ao longo do tempo, voltando seu foco sobremaneira para a questão textual/estrutural propriamente dita, preocupando-se em dar conta do processo de transformação linguística por que passam os textos envolvidos no ato tradutório. Cabe ressaltar que o conceito de ato tradutório contemplado no escopo de minha tese é o que consiste na tradução interlingual, ou 
seja, a transformação de um texto produzido na língua A e transformado em outro texto, este produzido na língua $B$, mesmo ciente de outras modalidades conceituais de tradução desenvolvidas por Roman Jakobson (2010, p. 79-91). Uma perspectiva mais contextual, por assim dizer, foi inaugurada em meados da década de 1970 com as teorias de orientação sistêmica, cujo primeiro nome de expressão foi o do estudioso israelense Itamar Even-Zohar com sua teoria de polissistemas, que será oportunamente discutida.

Com base nessa contextualização da prática tradutória, é possível afirmar que essa aproximação entre povos e culturas tão diversos promovida pela tradução é socialmente condicionada. Desse modo, se um texto produzido na língua A é traduzido para a língua B, significa que a comunidade linguística que não domina a primeira, mas tem a segunda por vernáculo, demandou, por quaisquer propósitos, que se executasse essa transformação linguística. É possível, portanto, afirmar-se que há, subjacente à prática tradutória, toda uma dinâmica sociológica e mercadológica, em que se estabelecem relações de consumo, como descreve Even-Zohar:

[...] [Um] CONSUMIDOR talvez "consuma” um PRODUTO produzido por um PRODUTOR, mas, para que o "produto" (como, por exemplo, um texto) seja gerado, um REPERTÓRIO ${ }^{1}$ comum precisa existir, cujo uso é determinado por alguma INSTITUIÇÃO. Um MERCADO, onde essa mercadoria seria transmitida, precisa existir. Nenhum dos fatores enumerados pode ser descrito para funcionar isoladamente e o tipo de relações provavelmente detectado atravessa todos os possíveis eixos do esquema. (EVEN-ZOHAR, 1990, p. 34) ${ }^{2}$

A pesquisa que desenvolvi teve por objetivo geral identificar e analisar as etapas que compõem o processo de publicação de obras literárias traduzidas no Brasil, processo este conduzido, de um modo geral, pelas casas editoriais. Ao examinar essa cadeia, meu estudo, portanto, vai além de mostrar que o tradutor

\footnotetext{
${ }^{1}$ Even-Zohar concebe como repertório o conjunto de regras que norteiam a produção e o consumo de um determinado produto, ou seja, o conhecimento que precisa ser partilhado por entre os que produzem e consomem os produtos gerados dentro de um sistema literário.

${ }^{2}$ A tradução de todas as citações originalmente escritas em língua inglesa é de minha autoria.

${ }^{3}$ [...] a CONSUMER may "consume" a PRODUCT produced by a PRODUCER, but in order for the "product" (such as a "text") to be generated, a common REPERTOIRE must exist, whose usability is determined by some INSTITUTION. A MARKET must exist where such a good can be transmitted. None of the factors enumerated can be described to function in isolation, and the kind of relations that may be detected run across all possible axes of the scheme. (EVEN-ZOHAR, 1990, p. 34)
} 
não é o principal responsável pela versão final do texto traduzido, a que vai ao prelo, como acredita o senso comum. Diferentemente disso, revelará todo o conjunto de agentes (e suas respectivas ações) que atuam ao longo desse processo e que interferem em maior ou menor grau na versão do texto traduzido que chega às mãos do leitor. Assim sendo, tive por meta a busca, junto a editoras e aos diversos profissionais envolvidos, pela definição de critérios quanto à escolha das obras a serem traduzidas para o português; a aquisição dos direitos autorais das obras estrangeiras (de que forma se efetua essa aquisição e que elementos participam desse processo, como o autor, a editora que publicou o original, o agente literário e o scout ${ }^{4}$, por exemplo); a identificação dos profissionais a quem são confiadas a tradução e a revisão das obras estrangeiras adquiridas e a descrição da relação entre eles, caso haja; a definição de expectativas quanto à qualidade das traduções e o que o mercado editorial, como um todo, entende por "boa tradução"; a observação sobre o tratamento que recebem os elementos paratextuais dos livros traduzidos (capa, prefácios/posfácios e afins, orelha); a escolha dos títulos das obras traduzidas, considerando-se a significativa importância mercadológica desse quesito; a organização dos cronogramas de publicação de livros traduzidos (por vezes, o lançamento da obra original e o da sua versão traduzida para o português, se não simultâneos, acontecem em datas próximas; segundo informou uma das editoras entrevistadas, em plena era digital, uma lacuna entre o lançamento do original e o da tradução pode acarretar um fracasso de vendas); a verificação do ranking de línguas traduzidas (A cultura anglófona ainda mantém sua liderança nos dias de hoje?); qual é o papel dos designers de capa na confecção de uma obra traduzida; como as editoras preparam o seu material de divulgação; qual é o papel das resenhas na recepção de uma obra traduzida; como atuam os livreiros nesse processo. Embora essas práticas sejam bastante semelhantes entre as editoras, há suficientes diferenças de procedimento que impossibilitam uma ampla generalização. Tendo isso em vista, procurei enfocar mais detalhadamente as práticas editoriais do Grupo Editorial Record, sediado no Rio de Janeiro, tentando entrevistar o maior número possível de profissionais dessa empresa que atuam nas diferentes etapas de que se compõe o

\footnotetext{
${ }^{4}$ Sobre esse agente falar-se-á mais adiante.
} 
processo de publicação de obras literárias traduzidas. Os dados levantados foram complementados com informações de outras fontes (entrevistas com profissionais da área, alguns por mim entrevistados e outros cujas experiências encontram-se registradas em textos e/ou em entrevistas disponíveis na internet), na tentativa de traçar um percurso relativamente comum das obras estrangeiras transpostas para o nosso vernáculo. Duas são as razões que justificam o meu interesse pelo tema aqui proposto: do ponto de vista pessoal, foi a minha experiência como preparadora de originais (denominação adotada pela editora à época) para uma grande editora também baseada na cidade do Rio de Janeiro que despertou a minha curiosidade sobre o processo, foco do presente estudo; do ponto de vista coletivo, penso ser oportuno investigar como se perfaz a publicação de literatura traduzida dentro de uma estrutura macro e receptora, que é a literatura nacional, levando-se em consideração também o fato de que o Brasil é um grande consumidor de traduções.

A presente tese objetiva, portanto, identificar, descrever e analisar cada etapa do processo de publicação de obras traduzidas, tendo por foco principal os agentes que desempenham as atividades que compõem cada uma delas. Ao voltar a minha atenção para o tradutor e o profissional de copidesque, pude verificar o grau de responsabilidade do tradutor pelo produto final e pela imagem que se cria da obra e do autor na cultura de recepção. Afinal, formalmente falando, na ficha catalográfica das obras traduzidas e publicadas no Brasil, registra-se tão-somente o nome do tradutor ${ }^{5}$, o que poderá induzir o leitor comum a imaginar que aquele profissional seja o único agente da etapa de confecção textual, enquanto que, pelo menos quem milita na área, sabe que o texto estrangeiro, depois de traduzido, passa, pelo menos, por uma etapa de revisão. Inicialmente, a minha intenção era entrevistar profissionais de diferentes editoras de modo a fazer um estudo comparativo entre as práticas editoriais observadas. No entanto, percebendo que o trabalho ficaria extenso demais, foi necessário optar por priorizar a geração de dados junto ao Grupo Editorial Record por se tratar de uma editora de grande porte, que abriga diversos selos, com práticas editoriais não necessariamente

\footnotetext{
${ }^{5}$ Algumas editoras fazem menção ao preparador de originais, cujo nome não consta propriamente da ficha catalográfica, mas, sim, do que se chamará aqui de "expediente".
} 
homogêneas, além de ter sido a editora que, desde o início de meu estudo, mostrou-se mais receptiva ao meu projeto.

Assim, para empreender o estudo que tinha em mente, iniciei a minha abordagem tentando mostrar o quanto são desconhecidos do grande público os bastidores da confecção de uma obra traduzida, incluindo nesses bastidores todas as atividades que concorrem para a sua realização, bem como os agentes que as executam. Em seguida, no primeiro capítulo, apresento os fundamentos teóricos que embasam a minha pesquisa, partindo da visão de literatura como sistema, desenvolvida por Itamar Even-Zohar, passando por noções e conceitos formulados por Gideon Toury, André Lefevere e Lawrence Venuti, até chegar às abordagens de natureza sociológica. Os três capítulos subsequentes se voltam para o aspecto mais pragmático, por assim dizer, do trabalho aqui desenvolvido, pois têm por objeto não apenas as práticas editoriais propriamente ditas, como também seus respectivos agentes. Desse modo, o segundo capítulo procura dar conta dos possíveis canais entre uma obra estrangeira e uma casa editorial importadora, no caso, brasileira. Os dois capítulos que se seguem têm por objetivo analisar os atores incumbidos da confecção do texto traduzido. Enquanto no terceiro capítulo discorre-se sobre o tradutor, agente responsável pela etapa central do processo aqui investigado (a tradução), no quinto, o foco são os agentes encarregados da lapidação do texto traduzido, que por ora denominaremos genericamente de revisores. O quinto capítulo está dedicado a investigar o que chamamos aqui de pós-produção, ou seja, depois de totalmente confeccionada, como a obra traduzida é distribuída pelas livrarias e recebida pelo público, seja especializado ou leigo. Por fim, apresento as conclusões a que cheguei com base não só nos dados gerados e coletados, procurando, sempre que possível, estabelecer uma conexão entre teoria e prática.

Entendo que a relevância do meu estudo resida na análise teórica de um processo que, à semelhança do fenômeno tradutório, se dá eminentemente na prática, processo este que envolve grandes investimentos financeiros mundo afora, visto se tratar de um dos muitos nichos altamente lucrativos da indústria do entretenimento. Afinal, é na troca de produtos por valores monetários que repousam as relações de consumo, às quais a indústria e o comércio livreiros não constituem uma exceção. Dentro do vasto e complexo conceito de "capitalismo", 
termo cunhado por seu mais ferrenho crítico, Karl Marx, entendo que o mais pertinente aqui seja a questão das relações de consumo, ideia que engloba conceitos como produção, comércio, consumo e lucro, conceitos estes que, ao que parece, formam uma cadeia em que cada um deles constitui uma etapa (MISES, 2009, p. 21) ${ }^{6}$. Começo, então, pela última etapa, a do lucro. Para garantir a sua obtenção, o setor produtivo (indústria) precisa controlar a qualidade da sua produção, e o setor comercial, por sua vez, precisa lançar mão de estratégias para atrair o consumidor final e fazer com que ele opte pela mercadoria ali oferecida. Ao término dessa cadeia, de um lado, indústria e comércio auferem lucros e, do outro, o consumidor tem suas necessidades satisfeitas. Friso aqui que, no caso do Brasil, a alta incidência de impostos ao longo de toda essa cadeia afeta negativamente a produção e, consequentemente, a venda e o consumo. Aliado a isso, deve-se considerar a questão da concorrência que, inerente ao sistema capitalista, é, por um lado, salutar para o desenvolvimento das empresas e, por outro, benéfica para o consumidor, que terá mais opções de escolha de produtos e serviços. Para tentar vencer a concorrência, tanto a indústria quanto o comércio precisam oferecer vantagens com o intuito de cativar o consumidor e, com isso, cultivar o que o mundo corporativo denomina “fidelidade do cliente”. Não se deve esquecer que é o cliente final que por meio do consumo, mantém em funcionamento a dinâmica do polinômio "produção/venda/consumo/lucro". No que tange ao mercado livreiro em especial, vale lembrar que o livro, independentemente do gênero em que possa ser classificado, é um bem de consumo confeccionado para atender às necessidades de quem o quer ou dele precisa. Afinal, temos no Brasil uma sociedade de mercado que, como conceitua Mises (2015, p. 132), se caracteriza pela função social da propriedade privada (editoras) que tem por finalidade premente a satisfação de sua clientela, procurando sempre que possível aliar qualidade do produto e barateamento de custo, exemplificado aqui pelo "livro de bolso", ofertado por alguns dos selos do Grupo Editorial Record, como veremos adiante.

\footnotetext{
${ }^{6}$ Maior expoente da Escola Austríaca de Economia, Ludwig von Mises (1881 - 1973), teve sua obra Economic Policy: Thoughts for Today and Tomorrow publicada post-mortem em 1979. Sua tradução para o português do Brasil, realizada por Maria Luiza Borges, foi publicada pelo Instituto Ludwig Von Mises Brasil sob o título As seis lições e aborda temas da área econômica tais como sistemas político-econômicos (capitalismo e socialismo), intervencionismo e inflação, para citar alguns.
} 
Tendo, assim, apresentado os objetivos, motivações e justificativas para a pesquisa sobre os principais agentes do processo de publicação de obras traduzidas que me propus a empreender, com destaque para o papel do tradutor, passo, então, a apresentar o arcabouço teórico que alicerça este trabalho. 


\section{Fundamentação teórica e metodologia}

Pensando a literatura de forma sistêmica como propõe Even-Zohar, observa-se que, no âmbito acadêmico, o sistema de literatura traduzida sequer tangencia o de literatura vernácula ${ }^{7}$. Nos programas de literatura em ensino universitário, por exemplo, a literatura estrangeira é estudada na língua de origem e pelos alunos de graduação que se dedicam àquela cultura e à sua respectiva língua. Não é levada em conta, por conseguinte, a literatura estrangeira traduzida para o português, sendo a versão traduzida do cânone literário estrangeiro considerada uma mera alternativa de leitura para aqueles não habilitados a "beber da fonte genuína”. No entanto, diferentemente do que se possa imaginar, a literatura traduzida não se opõe à nacional e tampouco se constitui numa ameaça ao seu desenvolvimento e à sua sobrevivência. Na verdade, o sistema literário brasileiro pode se nutrir - e vem se nutrindo historicamente - dos modelos importados para se irrigar de ideias e formatos textuais novos, como alerta Monteiro (2013):

[t]raduzir é inscrever um texto em novo contexto histórico-social, com todas as repercussões que decorrem dessa inscrição[;] [o] sistema literário que recebe uma obra traduzida pode se beneficiar de novas formas de expressão, de novos padrões estéticos [...]. (MONTEIRO, 2013, p. 142)

Apesar de reconhecerem a influência da literatura estrangeira, notadamente a europeia, na formação e no desenvolvimento da literatura vernácula, nossos críticos literários, como argumenta Monteiro (2013, p. 142), pouco se atêm à tradução como o instrumento, a ferramenta que viabiliza formalmente essa influência. A propósito da contribuição estilística que a literatura traduzida pode proporcionar ao sistema literário receptor, Aguiar (1999, p. 144-145) cita o exemplo da prosa ficcional de meados do século XIX. Graças ao seu formato folhetinesco, ou seja, publicada a cada edição de um determinado folhetim, um periódico à época de alcance popular, esse gênero textual forneceu

\footnotetext{
${ }^{7}$ Por saber não se tratar de um conceito monolítico, esclarece-se que por "literatura vernácula" deve-se entender o termo aqui como o conjunto de obras literárias produzidas no registro padrão da língua materna, no caso do presente estudo, o português do Brasil.
} 
técnicas narrativas até então inexistentes no sistema literário brasileiro. Dentre esses recursos técnicos, podem-se citar a interrupção da narrativa no clímax de uma passagem, uma simetria na extensão dos capítulos, a tipificação de personagens e o emprego do uso linear (cronológico) do tempo da narrativa. Como argumenta Aguiar, esses recursos não foram adaptados ao gosto do leitor brasileiro e, sim, importados diretamente do sistema literário originário, no caso o francês. Isto porque, não havia então um público leitor local, posto que ainda estava em formação. A autora prossegue ratificando a ideia de Even-Zohar de que a tradução pode ser, de fato, uma rica fonte de inovações no campo da literatura e não necessariamente uma força conservadora para preservar formas tradicionais.

Se, por um lado, sob uma perspectiva macro, o sistema literário tradutor se nutre do traduzido, deste importando novos padrões estéticos, por outro, sob uma perspectiva mais micro, o processo inverso pode também ocorrer, ou seja, o original pode, em alguns casos, beneficiar-se da tradução. Nesse último caso especificamente, não se trata da absorção de novas propostas estéticas desenvolvidas durante a tradução, pois, para tanto, seria necessário que a versão traduzida circulasse no sistema literário receptor (o traduzido), lado a lado com o texto fonte, o que, pelo menos em tese, parece ser pouco provável. Pelo que pude apurar durante a minha pesquisa, o benefício que a tradução pode proporcionar ao texto de partida parece se restringir a inadequações nele detectadas. Entendo que aprimoramentos do ponto de vista textual/estético, seja de natureza temática ou linguística, dificilmente virão a ocorrer. Durante a entrevista a mim concedida em setembro de 2018, a editora Renata Pettengill, do Grupo Editorial Record, citou dois exemplos interessantes em que os autores - um deles o campeão de vendas John Green - se beneficiaram da tradução, pois imprecisões detectadas em seus textos originais foram corrigidas na versão traduzida. O caso citado por Pettengill envolvia o valor de $\pi$, elemento relevante para o desenrolar da trama. Percebido o equívoco, a editora enviou email ao autor alertando do fato. Agradecido, Green prontamente a autorizou a proceder à correção.

De acordo com o ordenamento cronológico adotado por Laurence Hallewell (2012), a importação de textos escritos em língua estrangeira, com vistas a um mercado brasileiro consumidor de leitura, data de meados do século XIX e tem como precursor Baptiste Louis Garnier. O sucesso das edições Garnier 
no Brasil coincide com o crescimento do público leitor proveniente de uma classe média em formação, a quem se ofereciam os romancistas à época em voga - e, consequentemente, rentáveis - como Dumas (pai), Vitor Hugo e Júlio Verne.

No panorama atual, de acordo com dados disponibilizados pela Câmara Brasileira do Livro em seu site oficial, no biênio 2012/2013 houve um aumento de 5,28\% no volume de títulos traduzidos lançados no Brasil e de 1,42\% no total de vendas desses títulos. Em contrapartida, o percentual de livros nacionais lançados no mesmo período teve um acréscimo de $8,61 \%$, mas com uma retração de 3,87\% nas vendas. Os dois dados numéricos positivos referentes ao lançamento e às vendas de obras traduzidas demonstram um equilíbrio que a produção nacional não conseguiu manter no referido período. Em suma, a investigação do processo de publicação de livros traduzidos no Brasil, além de ser uma curiosidade nascida de uma experiência profissional, justifica-se pela importância da literatura traduzida para a expansão do repertório literário brasileiro. Nos últimos relatórios emitidos pela instituição, que datam do ano de 2016, no entanto, não há menção a dados comparativos entre o número de obras traduzidas e o de obras produzidas em português publicadas no Brasil. Entretanto, a Fundação Instituto de Pesquisas Econômicas (Fipe) divulgou em seu site ${ }^{8}$ um levantamento estatístico com base no balanço de vendas das editoras brasileiras referente ao biênio 2017/2018. De acordo com os dados da tabela, há, dentre títulos lançados e exemplares produzidos, um volume consideravelmente maior de obras nacionais, sobretudo se considerarmos a primeira variável (títulos lançados). No entanto, se se observar a coluna em que figura o número de exemplares produzidos, observar-se-á um aumento quanto aos livros traduzidos, o que nos induz a concluir que, no biênio em questão, houve uma demanda comercial maior de reimpressão de livros traduzidos, totalizando um percentual de 22,6\%. Em contrapartida, a reimpressão de exemplares de obras nacionais sofreu uma retração de $-18,8 \%$. O que explicaria essa diferença tão significativa? Somente uma investigação in loco em um número considerável de editoras poderia apontar possíveis causas dessa assimetria quantitativa.

\footnotetext{
${ }^{8}$ Disponível em: http://pesquisaeditoras.fipe.org.br. Acesso em 15/12/2019.
} 
Visto que tive por objetivo examinar a tradução sob uma perspectiva editorial mercadológica, e não textual, penso ser legítimo afirmar que as abordagens de diretriz sociológica no âmbito dos Estudos da Tradução mostraram-se especialmente adequadas para desenvolver o estudo aqui proposto. Desse modo, minha tese partirá da premissa de que a tradução possui uma função social, visto ser considerada como o acesso indireto conferido a uma determinada comunidade linguística que não domina o idioma em que os textos traduzidos foram originalmente escritos. Levando-se em consideração a concepção sistêmica da literatura desenvolvida por Itamar Even-Zohar, pode-se identificar a literatura traduzida como um sistema integrado ao sistema literário da cultura de chegada. Este, por sua vez, incorpora-se ao "sistema literário internacional, [formando] uma constelação de grupos linguísticos [...]”, como argumenta Johan Heilbron (2010, p. 310). Ainda segundo o estudioso holandês, uma abordagem mercadológica se faz crucial para se entender o papel da tradução numa determinada cultura, pois ajudará a conectar as dinâmicas do que ele entende por sistema internacional de tradução e do mercado editorial.

Considerando, então, que minha proposta foi investigar como se dá esse conjunto de ações coordenadas com vistas a transformar a tradução em produto comercial, o meu estudo se sustenta basicamente nas seguintes abordagens, conceitos e visões: 1) a concepção de literatura como polissistema, desenvolvida por Itamar Even-Zohar; 2) o entendimento da tradução como fenômeno da cultura tradutora, concebida por Gideon Toury; 3) os conceitos de reescrita e patronagem, propostos por André Lefevere; 4) a visão de tradução como agente formador das literaturas nacionais, promovido por Lawrence Venuti; 5) as abordagens de orientação sociológica propriamente dita, que trazem nomes como Michaela Wolf, Pascale Casanova, Daniel Simeoni, Maria Timoczko e Johan Heilbron, dentre outros. Em virtude disso, a seção de minha tese dedicada à fundamentação teórica conta com cinco subdivisões, cada uma tendo por foco uma das abordagens pertinentes ao meu estudo, tendo uma subseção adicional versando sobre o Grupo Editorial Record, onde a minha proposta de pesquisa encontrou boa receptividade e que, direta ou indiretamente, foi responsável por boa parte das entrevistas aqui citadas e comentadas. Complementando essas fontes, entrevistei também agentes 
que atuam em outras casas editoriais de modo a poder ampliar o meu campo de observação.

No tocante à metodologia, entendo que a natureza de minha pesquisa seja predominantemente de cunho qualitativo, visto que tive por fonte de consulta os dados gerados durante os depoimentos dos indivíduos envolvidos nessa cadeia de profissionais e atividades que se forma com vistas à publicação de literatura traduzida no Brasil. Entretanto, a despeito de ter por referência narrativas subjetivas, impressões e opiniões dos participantes das entrevistas empreendidas, em determinados momentos precisei lançar mão de dados numéricos para ilustrar as informações fornecidas ao longo desses encontros. Por conseguinte, as entrevistas feitas podem ser classificadas como semiestruturadas, uma vez que se realizaram a partir de um roteiro previamente definido, mas com flexibilidade suficiente para explorar a posteriori algumas questões não previstas, mas que surgiram e se revelaram interessantes para o estudo. Em razão disso, entrevistei profissionais direta ou indiretamente ligados à área, que me forneceram informações relevantes tanto a respeito do aspecto produtivo/comercial do processo investigado, quanto do aspecto literário, textual e temático, no qual reside a especificidade do produto aqui em questão. Além das entrevistas efetivamente realizadas para este estudo, buscou-se na internet material cujo conteúdo pudesse acrescentar aos dados já coletados e gerados.

Dentre os participantes entrevistados estão:

- Renata Pettengill, editora do Grupo Editorial Record, atualmente responsável pela publicação de títulos traduzidos;

- Silvia Leitão, ex-editora do Grupo Editorial Record e da Ubook, hoje atuando como gestora de catálogos na livraria online Auti Books;

- Raquel Zampil, tradutora de diversas casa editoriais e editora da Revista Seleções;

- Anastácia Cabo, responsável pelo blog Notas Literárias e editora na Gift Box;

- Renata Vidal, designer de capa; 
- Prof ${ }^{a}$ Teresa Dias Carneiro, tradutora e docente da PUC-Rio, onde atua na formação de tradutores e pesquisadores sobre tradução;

- Prof $^{a}$ Lourdes Sette, tradutora e docente da PUC-Rio, atuando na Especialização para formação de tradutores;

- Rodrigo Austregésilo, copidesque;

- Suelen Lopes, editora em uma grande empresa do ramo.

Considerando ainda que um dos traços mais distintivos da sociologia é a sua natureza empírica, como argumenta Buzelin (2013, p. 190), muitas são as possibilidades em termos de métodos empregados com o objetivo de coletar e gerar dados. Desse modo, de acordo com os níveis de análise apresentados por Buzelin (2013, p. 190), o escolhido foi o da mesoanálise, em que se examinam "as

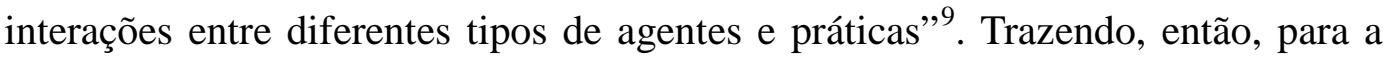
cena analítica um número maior de elementos, foi possível formar uma ideia mais generalizante da dinâmica que ocorre dentro do campo editorial. Entretanto, friso que o que observei no Grupo Editorial Record não se aplica ipsis litteris a outras empresas do ramo, uma vez que cada uma tem sua filosofia, seu modus operandi, sua equipe, enfim, são universos particulares com características que ora se tangenciam, ora se afastam. Neste trabalho, procurei, a cada assunto enfocado, fazer uma ponte entre o relato do entrevistado e a bibliografia pertinente, no sentido de se comprovar - ou não - o que, em tese, os estudiosos da sociologia da tradução e a do traduzir vêm observando no mundo empírico.

Desse modo, as diretrizes do meu estudo têm por embasamento teórico o farto material constante das referências, cujos autores e ideias serão abordados oportunamente. Do ponto de vista pragmático, procurei extrair da experiência desses profissionais fatos que vieram não só ilustrar os aspectos abordados no âmbito teórico, mas também revelar outros não previstos. Deve-se frisar aqui, no entanto, que nem todos os conceitos presentes neste capítulo foram evidenciados empiricamente durante a elaboração desta pesquisa. Contudo, optei por mantê-los integralmente aqui no intuito de demonstrar o trabalho dos estudiosos para construir uma sociologia da tradução, tendo por pedra fundamental ideias

\footnotetext{
${ }^{9}[\ldots .$.$] interactions between different kinds of agents and practices [...]$
} 
elaboradas primeiramente no âmbito da sociologia geral. Desse modo, todo o arcabouço teórico aqui discutido tem por objetivo apresentar a conexão entre a sociologia e a sociologia da tradução, construída pelos teóricos aqui mencionados.

\section{1}

\section{A literatura traduzida como sistema integrado ao polissistema literário nacional: o modelo sistêmico de Itamar Even-Zohar}

Professor Emérito de Pesquisa em Cultura pela Universidade de Tel-Aviv, o israelense Itamar Even-Zohar se notabilizou pela chamada teoria de polissistemas, desenvolvida por ele com o intuito de analisar a dinâmica e a heterogeneidade que caracterizam a cultura, entendida aqui lato sensu. O conceito de sistema foi herdado por Even-Zohar da última geração de formalistas russos, notadamente de Iuri Tinianov, Roman Jakobson e Boris Eikhenbaum. Como observa Shuttleworth (1998, p. 176), o termo "sistema” foi desenvolvido por Tinianov originalmente para designar uma estrutura composta de diversas camadas em que se dispõem elementos que interagem, sendo esses elementos obras literárias consideradas individualmente. Posteriormente, em virtude de sua considerável flexibilidade, Even-Zohar passou a utilizá-lo para compreender a literatura como um todo e, mais tarde, para conceber a sociedade, também como uma ideia universal. Do ponto de vista terminológico, é prudente que se esclareça que, de certa forma, os termos “sistema” e "polissistema” podem ser usados de forma intercambiável em alguns contextos. No entanto, deve-se entender que a ideia transmitida pelo vocábulo "polissistema”, justamente em virtude da aposição do prefixo "poli”, é a de algo maior, composto por estruturas semelhantes, mas de dimensão menor - ou mais setorizadas - que, juntas, formam um conglomerado. Uma dessas estruturas sistêmicas, que associada a outras semelhantes compõe o sistema maior, é o sistema literário. Dada a diversidade de gêneros, escolas e estilos, a literatura, por si só, também pode ser considerada um polissistema.

Assim, compreendendo a literatura como um polissistema, ou seja, um sistema macro que abrange e integra-se a outros, Itamar Even-Zohar identifica dentre estes a literatura traduzida. Na sua visão, as obras traduzidas por uma determinada cultura compartilham características que lhes são imprimidas durante 
o processo tradutório, a começar pelos critérios seletivos que levam à sua importação. Ademais, ao longo do processo em que se dá a reescrita tradutória, o texto que se perfaz na língua meta adota normas da cultura receptora de modo a se tornar palatável ao público que vai consumi-la. A princípio, essa "palatabilidade" seria o que editores, tradutores e revisores chamam de "fluência". No polissistema literário concebido pelo teórico israelense, as obras nele geradas - incluindo as traduzidas - podem transitar por uma das “órbitas” que o compõem: o centro e a periferia. A literatura traduzida, via de regra, dentro de um dado polissistema literário, ocupa a periferia, por onde transitam as obras que, em sua estrutura hierarquizada, não produzem o mesmo impacto e não gozam do mesmo prestígio que as que preenchem o espaço central, pelo menos não naquele dado momento. Nesse aspecto, espero que a minha pesquisa, mediante os dados levantados junto a diferentes fontes, das quais se destacam as entrevistas realizadas com profissionais do mercado editorial e livreiro, tenha revelado, sob uma perspectiva sociológica, os procedimentos editoriais voltados para a tradução, e os agentes e as atividades que compõem cada etapa desse processo.

\section{2}

\section{A tradução como fenômeno da cultura tradutora: os estudos descritivos de Gideon Toury}

Discípulo de Itamar Even-Zohar, o teórico israelense Gideon Toury (19422016), foi, como consta do site Tradiling -Translation and language resources in Vic, Barcelona, Catalonia and the World, ao lado de Eugene Nida, "um dos pioneiros a transformar a tradução num objeto de estudo científico e numa disciplina [acadêmica] propriamente dita, merecedora de rigorosa pesquisa” ${ }^{10} 11$. Assim, em sua influente obra Descriptive Translation Studies - And Beyond,

\footnotetext{
${ }^{10}$ Disponível em:<https://www.tradiling.net/in-memoriam-gideon-toury-pioneer-of-descriptivetranslation-studies/ >. Acesso em 04/10/2018.

${ }^{11}[\ldots]$ among the most pioneering scholars, along with Eugene Nida, that converted translation into an object of scientific study, and into a discipline in its own right, deserving of rigorous research $[\ldots]$.
} 
Toury desenvolveu um ramo efetivamente descritivo ${ }^{12}$, que partisse de premissas explícitas e, munido de técnicas de pesquisa que se coadunassem com o escopo dos Estudos da Tradução, desse conta de analisar a tradução no lugar onde se processa: na cultura de chegada, ou seja, na cultura tradutora.

A ideia tradicional de tradução, que formou o senso comum acerca desse conceito, via (ou mesmo ainda vê) a atividade tradutória como mero transporte de significados, usando como parâmetro de aferição de qualidade a tão propalada “fidelidade ao original”. As teorias da tradução que se fundamentam nessa visão se revestem de um cunho prescritivo e assumem como objetivo estabelecer, ou melhor, "prescrever” como realizar uma "boa” tradução, tendo como ponto de partida da observação o texto fonte, a fim de verificar se o texto traduzido "reproduz" fielmente o sentido do original. Contrariando essa perspectiva reguladora, por assim dizer, a abordagem de natureza descritiva desenvolvida por Toury propõe o caminho inverso: que se parta do texto traduzido, observando a ambiência cultural em que o fenômeno tradutório se deu, para poder entender e explicar os produtos que dele resultaram. Concebendo-se o conjunto de textos literários traduzidos como um sistema, como dito na seção anterior, pode-se concluir que a importação de textos e sua subsequente tradução tenham por objetivo completar alguma lacuna que o polissistema literário receptor apresente naquele dado momento, como alega o próprio Toury: “[...] [o] ponto de partida é sempre [a ideia] de certa deficiência [...], algo [que] esteja faltando na cultura-

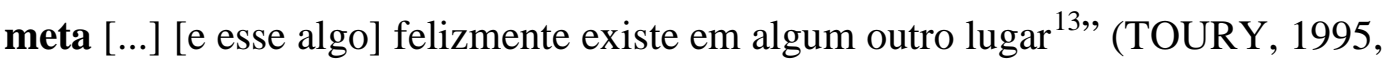
p.27, grifo meu). Paralelamente a essa função suplementar, por assim dizer, analisando a tradução como peça de uma engrenagem mercadológica, parece legítimo afirmar que é por intermédio da atividade tradutória que se amplia o raio de ação do comércio livreiro. E como bem observou Sapiro (2008, p. 158), “diferentemente da música ou da pintura, a circulação internacional de literatura

\footnotetext{
${ }^{12}$ Toury desenvolveu o ramo descritivo da estrutura da disciplina Estudos da Tradução proposta por James Holmes em "The Name and Nature of Translation Studies" (1972/1988). Holmes propõe duas primeiras subdivisões, "[E]studos da [T]radução puros" e "[E]studos da [T]radução aplicados" e, em seguida, subdivide os "puros" em "teóricos" e "descritivos".

${ }^{13}$ The starting point is always [the idea] of a certain deficiency [...] [,] something that is "missing" in the target culture [...] [and that something] luckily exists elsewhere.
} 
depende, em grande parte, da tradução”. Essa constatação feita pela estudiosa francesa permite-nos concluir que, em se tratando do comércio internacional de livros, a tradução amplia a circulação desse bem de consumo, permitindo que obras produzidas nas mais diversas culturas transponham fronteiras geográficas e barreiras linguísticas e, ao se transformarem em bens econômicos, tragam divisas para suas respectivas economias.

Desse modo, como num desdobramento da teoria dos polissistemas de Even-Zohar, Toury alega que a literatura traduzida ocupa um lugar no sistema literário importador, e é essa posição que vai determinar as estratégias a serem empregadas na produção de traduções. Para se analisar a tradução do ponto de vista descritivo, Toury sugere que se adote uma metodologia dividida em três estágios (three-phase methodology for systematic DTS). No primeiro, verifica-se o significado ou aceitabilidade da obra traduzida para a cultura tradutora, ou seja, as razões pelas quais aquela obra foi importada para a tradução e como aquele texto foi recebido pelo público leitor alvo. No segundo, realiza-se o cotejamento entre texto fonte e texto alvo com o objetivo de se identificarem segmentos correspondentes (coupled pairs) entre os dois. É a observação desses “pares casados” que permitirá a identificação de mudanças operadas na tradução, tanto as obrigatórias quanto as opcionais. No terceiro e último, tentar-se-á reconhecer, de forma generalizada, os padrões textuais formados ao longo da execução da tradução, padrões estes que permitirão identificar as estratégias adotadas. Esses padrões textuais incidem de forma regular, e essa regularidade acaba por constituir uma espécie de “corpo normativo”. Esse conjunto de regras é denominado por Toury de normas, conjunto este que não está compilado, posto em nenhum código. Formadas consuetudinariamente, essas normas são estabelecidas pela própria atividade tradutória, executada por agentes capacitados para tal, que partilham do mesmo ambiente cultural, visto que a atividade tradutória possui significado cultural e desempenha função social (TOURY, 1995, p. 53). Por conseguinte, depreende-se que as normas tradutórias devam variar não só de cultura para cultura, se consideradas sincronicamente, mas também conforme o recorte cronológico em que a tradução se dá, podendo variar, portanto, dentro de uma mesma cultura, mas em momentos diferentes. 


\section{3}

\section{O conceito de patronagem e o poder manipulador das reescritas: a proposta teórica de André Lefevere}

Considerado fundamental agente na definição dos Estudos da Tradução como disciplina acadêmica, o teórico belga André Lefevere (1945-1996), por intermédio de suas inúmeras publicações, contribuiu enormemente para demonstrar o quanto a tradução pode revelar a respeito da conexão entre culturas diversas entre si, mas que, por razões igualmente diversas, acabam por estabelecer contato.

Em parceria com a estudiosa britânica Susan Bassnett, Lefevere lança em 1990 uma coletânea de artigos sob o título Translation, History and Culture, em cuja introdução os dois autores propõem uma análise da tradução que vá além da palavra e do texto, este compreendido estritamente no sentido linguístico. Munday (2012, p. 192) assim resume a proposta teórica dos dois autores:

[Lefevere e Bassnett] vão além [da questão linguística] e voltam seu foco para a interação entre tradução e cultura, para a forma como a cultura afeta e impõe restrições à tradução e para "um panorama mais abrangente envolvendo os conceitos de contexto, história e convenções" ${ }^{14}$.

Dentre os conceitos desenvolvidos por Lefevere, porém, o que se mostra mais relevante é o do agente que, dotado de poder econômico e/ou político, dispõe de recursos para viabilizar o processo que aqui investigo. Assim, passarei agora a discorrer, ainda que sem maior profundidade, acerca do indivíduo ou entidade que exerce o que Lefevere define por agente de patronagem, ou seja, que age como tutor da importação, tradução, publicação e comercialização de literatura. Trazendo o conceito de sistemas para o seu modelo teórico, Lefevere concebe a literatura como um sistema constituído não apenas pelas obras que formam um determinado acervo, mas inclui também dois tipos de agente: iniciando o fluxo de produção textual, há os que produzem esse repertório (escritores e reescritores, independentemente do gênero de reescrita - tradução, adaptações várias etc.) e, na

\footnotetext{
${ }^{14}$ [Lefevere and Bassnett] go beyond language and focus on the interaction between translation and culture, on the way in which culture impacts and constrains translation and on 'the larger issues of context, history and convention' (ibid: 11).
} 
ponta final dessa cadeia, aqueles que consumirão essas obras, sejam leitores especializados (crítica) ou leitores comuns:

Algumas variáveis da crítica sociológica, algumas críticas baseadas na teoria das comunicações e várias correntes da crítica baseadas em respostas do leitor [reader-response criticism] contribuíram muito para um clima no qual é novamente possível se pensar a literatura em termos de sistema. (LEFEVERE, 2007, p. 29)

Nesse elenco de agentes, estão também as editoras que, ao selecionarem as obras a serem traduzidas e postas no mercado, acabam por influenciar o repertório literário disponível na cultura de chegada. Segundo Lefevere, a opção (da escolha da obra até a escolha da capa, como investiguei) feita pelos agentes envolvidos no sistema literário, notadamente aqueles que produzem textos - escritores e reescritores - vai afetar diretamente a disponibilidade dos textos. Estando em conformidade com a poética vigente naquele sistema receptor, as obras literárias terão mais chances de serem divulgadas, seja indo ao prelo ou, mais contemporaneamente, veiculadas no meio digital. Lefevere, então, identifica no sistema literário dois fatores, ou mecanismos de controle, a serem considerados: um, de natureza interna, que se refere à produção textual propriamente dita, e outro, de origem externa, que estabelece os parâmetros que nortearão em alguns casos e, em outros, modularão essa mesma produção textual. O fator que se manifesta no interior do sistema literário é posto em prática por profissionais como escritores, tradutores, editores, críticos e professores da área, ou seja, pelos reescritores. Serão eles os responsáveis por produzir obras que se coadunem ou se oponham à ideologia e à poética em vigor naquele momento. É nesse âmbito interno que se desenvolve a reescrita tradutória, outro conceito concebido por Lefevere, e sobre o qual passo a discorrer aqui. Diferentemente do que o termo possa sugerir num primeiro momento, "reescrita” não se restringe à produção textual em seu sentido estrito. De acordo com o que consta do texto de apresentação da obra de Lefevere (2007), o termo contempla, além da tradução e da revisão, por exemplo, “[a] antologização, [a] historiografia, [a] crítica [e a] edição” (2007, p. 5) de uma obra literária, operações que interferem na sua recepção, podendo ensejar futuramente sua canonização na cultura tradutora. Assim, ao se importar uma obra estrangeira e, a partir dela, reelaborar-se um outro texto que funcionará como seu correspondente na cultura de chegada, ao se incluir 
uma obra numa antologia, ou ao se proceder a modificações textuais, processa-se o que Bassnett e Lefevere (2007, p. 11) classificam de "manipulação literária”. Com base nos exemplos citados no texto de apresentação da obra de Lefevere (2007, p. 5), entendo que a manipulação literária se dá tanto na esfera textual, quando o texto sofre intervenções (tradução, revisão e edição), quanto na extratextual, esta ficando a cargo dos agentes que falam, analisam e pesquisam a produção literária. Empregando aqui a terminologia e o conceito desenvolvido por Gérard Genette (1930-2018), eu me arriscaria a dizer que a manipulação que é feita nesse estrato pode também receber a designação de "paratextual”", visto que se trata de textos exógenos ao texto literário, mas que têm por função comentá-lo e, no caso do traduzido, também situá-lo no sistema que o acolhe. O segundo conceito, este de caráter externo e concebido por Lefevere como um sistema, opera fora do sistema literário e pode se definir como uma rede de poderes que favorecerá ou dificultará a publicação de obras literárias, mesmo na era da internet. Tendo como agentes pessoas atuando individualmente ou associadas a instituições, esse fator de controle é chamado por Lefevere de "patronagem”"16. Imbuído de relevante traço ideológico - devendo-se entender "ideológico" aqui não apenas no sentido político, como alerta o próprio Lefevere - os agentes da patronagem

tentam regular a relação entre o sistema literário e os outros sistemas que, juntos, constituem uma sociedade, uma cultura. Como regra, operam por meio de instituições montadas para regular, senão a escritura da literatura, pelo menos a sua distribuição: academias, departamentos de censura, jornais de crítica e, de longe o mais importante, o estabelecimento de ensino. (LEFEVERE, 2007, p. 35)

Creio que a investigação por mim empreendida tenha me credenciado a traçar um perfil de como as editoras brasileiras, tendo por parâmetro o depoimento dos participantes desta pesquisa, ou seja, tendo por referência maior os agentes associados ao Grupo Editorial Record, exercem essa patronagem na atualidade.

\footnotetext{
${ }^{15}$ Comentar-se-á esse conceito no capítulo 3 deste trabalho.

${ }^{16}$ Na edição consultada para este trabalho, traduzida por Claudia Matos Seligmann, em vez de “patronagem”, o termo empregado foi “mecenato”.
} 


\title{
1.4
}

\section{A tradução como agente formador de identidades culturais: o poder político da tradução, como propõe Lawrence Venuti}

\begin{abstract}
Notabilizado pelos conceitos de "invisibilidade do tradutor" - este discutido um pouco mais profundamente no Capítulo 3 deste trabalho - e das estratégias tradutórias da “domesticação” e da “estrangeirização”, o teórico norteamericano Lawrence Venuti marca a sua atuação nos Estudos da Tradução clamando por uma ampliação do escopo da área, de forma a se observar sobremaneira o viés valorativo, intrínseco ao sistema sociocultural. Desse modo, Venuti critica o conceito de normas elaborado por Gideon Toury por considerar, segundo ele, tão-somente elementos de natureza linguística e literária, desconsiderando os de cunho político-ideológico, decisivos para a escolha das obras que, depois de traduzidas, circulam pela cultura receptora. Munday (2012, p. 217) resume de forma clara a visão de Venuti quanto às normas de natureza político-ideológica que subjazem às escolhas feitas pelo mercado editorial no que diz respeito à escolha das obras para a tradução:
\end{abstract}

\begin{abstract}
Além de governos e outras instituições motivadas politicamente, que têm o poder de censurar e de promover certas obras [...], os grupos e as instituições sociais a que Venuti se refere incluiriam os vários atores da indústria editorial como um todo. Sobretudo, seriam esses [atores] editores que escolhem obras para tradução, remuneram tradutores e, com frequência, estabelecem o método tradutório. [Dentre esses atores], estão também inclusos agentes literários, equipes de marketing e vendas e críticos, [cujos] comentários indicam e, até certo ponto, determinam como as traduções devem ser lidas e recebidas na cultura alvo. Cada um desses atores ocupa uma posição e desempenha um papel nas agendas política e cultural dominantes no seu tempo e no seu espaço. Os próprios tradutores fazem parte dessa cultura, a qual podem aceitar ou contestar ${ }^{17}$.
\end{abstract}

\footnotetext{
${ }^{17}$ In addition to governments and other politically motivated institutions, which may decide to censor or promote certain works [...], the groups and social institutions to which Venuti refers would include the various players in the publishing industry as a whole. Above all, these would be the publishers and editors who choose the works and commission translations, pay the translators and often dictate the translation method. [These players] also include literary agents, marketing and sales teams and reviewers[, whose] comments indicate and to some extent determine how translations are read and received in the target culture. Each of these players has a particular position and role within the dominant cultural and political agendas of their time and place. The translators themselves are part of that culture, which they can either accept or rebel against.
} 
Para a realização desta pesquisa, porém, a ideia de Venuti que ocupará um lugar central será a formação de identidades culturais por meio da tradução. Entende o teórico norte-americano que, por intermédio do conjunto de textos traduzidos, a cultura tradutora forma uma imagem da cultura traduzida. Dependendo de como essa representação tenha sido delineada, a imagem da cultura traduzida poderá ter sido marcada pela reverência ou pelo estigma, tendo, inclusive o poder de influenciar as relações diplomáticas entre nações de culturas diferentes entre si (VENUTI, 2002, p. 130).

Assim, com base na premissa de que a tradução tem o poder de formar identidades culturais, creio poder evidenciar, por intermédio dos dados gerados pelas entrevistas realizadas que as editoras brasileiras funcionam como profícuo agente desse processo. Como alega Venuti, os efeitos produzidos pela tradução na cultura de chegada não se restringem à questão textual, linguística, mas perpassa todo o processo foco de meu estudo:

\begin{abstract}
Uma tradução, ao circular na igreja, no estado ou na escola, pode ter o poder de manter ou revisar a hierarquia de valores na língua-alvo. A escolha calculada de um texto estrangeiro [...] pode mudar ou consolidar cânones literários [...] e práticas comerciais na cultura doméstica [...] [O]s efeitos de uma tradução [vão] depender também dos vários fatores envolvidos na sua recepção [como] o layout da página[,] a arte da capa do livro impresso [e] a cópia para a divulgação. (VENUTI, 2002, p. 131)
\end{abstract}

\title{
1.5
}

\section{As abordagens de orientação sociológica}

Se, numa conversa informal, perguntarmos aos participantes leigos em matéria de tradução como imaginam um tradutor atuando, as imagens fornecidas poderão variar num ou noutro aspecto, mas um detalhe decerto será comum a todas as descrições: a de um indivíduo trabalhando solitário. Parece ser senso comum que a tradução é incondicionalmente e, sobretudo, por definição, uma atividade individual que, mesmo quando desenvolvida em equipe, é executada por apenas um sujeito. O caráter cultural e coletivo da tradução pode ser comprovado em inúmeros períodos da história da humanidade, desde a Antiguidade Clássica até a contemporaneidade, esta marcada pelos desdobramentos da globalização. Seja sob um ângulo mercadológico em que a tradução é vista como um serviço 
prestado dentro de uma cadeia (a de publicação de livros traduzidos, por exemplo) ou sob uma perspectiva mais macro em que se observa a tradução como ponte comunicativa entre povos atendendo a uma demanda político-econômica, o fato é que, por trás da imagem solitária do tradutor ${ }^{18}$, há uma rede de ações e agentes que, por um lado, demandam a tradução e, por outro, articulam-se para importá-la.

Analisar tanto essa malha de atividades e eventos quanto seus executores implicará necessariamente observar a tradução sob uma ótica sociológica, que veio na esteira da abordagem proposta pela chamada "virada cultural” ocorrida na década de 1980. O estudioso e pesquisador australiano Anthony Pym, no entanto, nega qualquer carência de "abordagens de caráter social e cultural no campo dos [E]studos da [T]radução”19 (PYM, 2006, p. 1), identificando essa perspectiva já em The Sociolinguistics of Interlingual Communication, de Eugene Nida (1996), um dos nomes mais representativos da abordagem linguística. O ponto para o qual Pym chama a atenção é que, mesmo na vertente sociológica dos Estudos da Tradução, o objeto de análise continua a ser o texto e nunca quem o produz ou promove:

[P]ode-se afirmar que todos os esforços empreendidos pelos Estudos Descritivos da Tradução, desde a década de 1970, têm sido no sentido de trazer para o âmbito dos [E]studos da [T]radução considerações contextuais mais amplas. Nesse sentido, abordagens de natureza social e cultural vêm sendo desenvolvidas há cerca de trinta anos, ou há mais tempo ainda (Nida publicou trabalhos importantes na década de 1940) ${ }^{20}$. (PYM, 2006, p. 2)

Ao conceituar a tradução "tanto como prática quanto como produto" (2007, p.1), a estudiosa austríaca Michaela Wolf identifica toda uma dinâmica coletiva que se perfaz mediante uma cadeia:

Qualquer tradução, tanto como prática quanto como produto, está necessariamente inserida em contextos sociais. Por um lado, o ato de traduzir, em todos os seus vários estágios, é inegavelmente executado por indivíduos que

\footnotetext{
${ }^{18}$ A imagem do tradutor como um profissional que desempenha suas funções de forma solitária é formada pelo senso comum. Profissionais e pesquisadores da área são conhecedores de modalidades de tradução realizadas em equipe, como a denominada crowd translation, por exemplo.

${ }^{19}$ There is no shortage of social and cultural approaches to translation.

${ }^{20}$ [O]ne could claim that the whole thrust of Descriptive Translation Studies, since the 1970s, has been to bring wider contextual considerations into the study of translation. In that sense, social and cultural approaches have been with us for thirty years or so, or considerably longer (Nida published important papers in the 1940s).
} 
pertencem ao sistema social; por outro, o fenômeno da tradução está inescapavelmente atrelado a instituições, que, em grande parte, determinam a seleção, a produção e a distribuição da tradução e, consequentemente, as estratégias adotadas durante a tradução propriamente dita. ${ }^{21}$ (WOLF, 2007, p. 1)

Johan Heilbron e Gisèle Sapiro (2007), por seu turno, alegam que uma abordagem que se possa classificar como sociológica deverá ter por meta examinar os vários aspectos envolvidos na circulação de bens culturais, dentre eles o livro traduzido. Segundo a proposta de Heilbron e Sapiro, uma análise da tradução sob uma perspectiva sociológica haverá de ser feita em três níveis: no primeiro, mapear o cenário internacional em que se dá a circulação de bens culturais; no segundo, examinar que fatores, sejam de ordem política ou econômica, regem essa troca de commodities; no terceiro, por fim, identificar os agentes que atuam nessa cadeia, os que intermediam a importação do produto editorial estrangeiro e os que o transformam para que seja aceito, recebido pela cultura importadora e, consequentemente, tradutora.

Boa parte dos teóricos que se ocuparam de delinear o que chamamos hoje de "sociologia da tradução" tomou como parâmetro os conceitos desenvolvidos por pensadores que, se não propriamente sociólogos, atuaram na área e os aplicaram à dinâmica coletiva da atividade tradutória. Dessa forma, o cabedal teórico dessa abordagem se compõe predominantemente dos conceitos elaborados por Pierre Bourdieu; da teoria ator-rede, desenvolvida por Bruno Latour e Michel Callon; e do modelo sistêmico, elaborado por Niklas Luhmann. Além de discutir a proposta teórica desses pensadores, o acadêmico inglês Andrew Chesterman desenvolve o que ele denomina de “conceitos-ponte” (bridge concepts) entre sociologia e tradução, no afã de evidenciar as zonas de contato entre os dois campos. Assim sendo, nas subdivisões seguintes, veremos os conceitos e as teorias de Bourdieu, Latour/Callon e Luhman, assim como os conceitos que Chesterman identifica na sociologia geral e que funcionam como ferramentas de integração com os Estudos da Tradução.

\footnotetext{
${ }^{21}$ Any translation, as both an enactment and a product, is necessarily embedded with social contexts. On the one hand, the act of translating, in all its various stages, is undeniably carried out by individuals who belong to a social system; on the other, the translation phenomenon is inevitably implicated in social institutions, which greatly determine the selection, production and distribution of translation and, as a result, the strategies adopted in the translation itself.
} 


\subsection{1}

\section{A contribuição do pensamento de Pierre Bourdieu, Bruno Latour/Michel Callon e Niklas Luhmann para uma sociologia da tradução}

Ao longo das últimas quatro décadas, mesmo antes da chamada "virada cultural”, os Estudos da Tradução já vinham testemunhando uma sucessão de mudanças no que se refere às suas perspectivas epistemológicas. Se, até meados da década de 1970, prevaleceu o enfoque de orientação estruturalista, formalista e linguística, voltado para a busca da fidelidade e da equivalência, a partir daquele ponto, o espectro analítico ampliou-se sobremaneira e voltou seu interesse para os múltiplos aspectos contextuais que não só orbitam ao redor da tradução, mas também concorrem, de forma direta ou indireta, para que a atividade tradutória se perfaça. Em virtude do crucial papel que vem desempenhando historicamente, a tradução tem suscitado reflexões acerca da sua execução. O interesse sobre a tradução data da Roma Antiga, quando Cícero e Horácio discorreram sobre o fenômeno em suas obras Libello de optimo genere oratum e Ars Poetica, respectivamente. Da Antiguidade Clássica até meados da década de 1970, no entanto, o enfoque dado à análise teórica da tradução se restringia às transformações de natureza gramatical (sintáticas, lexicais e fonéticas, estas cruciais para a tradução de poesia) e de natureza estilística por que passava o texto de origem durante o processo da tradução. Em suma, pensar e falar sobre a tradução se circunscrevia predominantemente ao campo linguístico: observar tãosomente as alterações estruturais sofridas pelo texto fonte, escrito na língua A, e transformado no texto traduzido, escrito na língua $\mathrm{B}$. O debate trazido à baila por ambos os oradores romanos girava em torno de duas alternativas em termos de estratégia tradutória: traduzir "palavra por palavra" ou traduzir "sentido por sentido". É nessa dicotomia que se identifica a gênese de três dos conceitos/temas centrais e recorrentes nos Estudos da Tradução: fidelidade, fluência e (in)traduzibilidade. Desse modo, tendo em vista apenas o texto, stricto sensu, as reflexões e os comentários sobre a tradução se voltaram para como manter a fidelidade ao original, buscando a melhor estratégia para transpor os obstáculos 
tradutórios, sendo estes os elementos textuais (linguístico-culturais) considerados intraduzíveis.

No entanto, se ampliarmos a objetiva com que se examina uma tradução, voltaremos a atenção para o que a circunda: a transformação do texto escrito na língua fonte no texto reescrito na língua meta foi executada para atender a uma necessidade específica de um indivíduo ou de um grupo. Atender a essa necessidade provocou não só a atuação de alguém tecnicamente capaz de levar a cabo essa transformação interlingual, mas também acarretou a intervenção de atores externos - indivíduo ou instituição - que intermediassem e promovessem essa metamorfose textual. Desse modo, o objeto de análise será algo exógeno ao texto, algo que lhe seja concernente, mas de forma periférica, situacional. Percebe-se, então, que, com vistas à produção de um texto traduzido, independentemente de sua natureza (literária ou técnica), forma-se uma rede de agentes (indivíduos e grupos), cada qual com sua tarefa própria. Essa rede de agentes e tarefas se verifica em inúmeros campos, a saber: acadêmico (tradução de textos versando sobre as mais variadas áreas), farmacêutico (tradução de bulas de remédio), tecnológico (tradução de manuais de equipamentos e protocolos técnicos), para citar e exemplificar alguns. Por tudo até aqui exposto, seria legítimo afirmar que a tradução, vista historicamente apenas como uma prática linguística, pode ser analisada como uma prática social, uma vez que sua execução envolve uma cadeia de indivíduos e instituições. Corroborando essa abordagem sociológica da tradução, a teórica austríaca Michaela Wolf alega que, por trás de um texto traduzido, independentemente do gênero a que possa pertencer, existe toda uma cadeia operacional formada por indivíduos e entidades, cadeia esta movida a partir de uma necessidade mercadológica. Uma vez manifesta essa necessidade, articula-se toda uma rede de agentes e tarefas com o objetivo de produzir aquele texto traduzido, contemplados aí todos e quaisquer elementos textuais e contextuais.

Examinando a sociologia da tradução sob uma ótica diacrônica, identificase em James Holmes e em Itamar Even-Zohar o pioneirismo dessa abordagem contextual, embora Pym (2006) discorde e identifique já nos trabalhos de Eugene Nida essa preocupação em observar o caráter conjuntural da tradução, como já mencionado anteriormente. Em sua participação no $3^{\circ}$ Congresso Internacional de 
Linguística Aplicada, realizado na cidade de Copenhagen, em agosto de 1972, quando discutiu acerca do escopo dos Estudos da Tradução, Holmes alertou para a existência de aspectos pertinentes à área, muito pouco explorados apesar da sua importância, e que não se referiam estritamente ao âmbito textual/gramatical. Ao traçar o campo de análise para o estudo do fenômeno tradutório, Holmes menciona “o complexo de problemas ao redor do traduzir e das traduções ${ }^{22 \text { " }}$ (Holmes, 1972, p. 67). Cerca de três anos após a apresentação de Holmes, o teórico israelense Itamar Even-Zohar desenvolve a sua teoria dos polissistemas, já abordada em 1.1. Então incipientes, nem o artigo de Holmes e tampouco o modelo teórico de Even-Zohar conseguiram contemplar em seus respectivos escopos os Estudos da Tradução e o fenômeno tradutório em toda a sua plenitude, aprofundando determinadas questões em detrimento de outras.

No que diz respeito à análise da tradução, muitos aspectos e ângulos de observação só foram trazidos à baila por outros estudiosos que, paulatinamente, vieram a preencher as lacunas a que anteriormente se fez menção. Desde a reflexão seminal de Holmes (1972/1988), que delineou a estrutura da disciplina voltada para estudar o fenômeno da tradução e do traduzir, e do modelo sistêmico de Even-Zohar, outros estudiosos do fenômeno tradutório se dedicaram a desenvolver essa abordagem sociológica, tecendo, assim, uma teia de perspectivas e objetos de análise dentro da grande área dos Estudos da Tradução. Sem se esquecer de Gideon Toury que, a partir da teoria de polissistemas de Even-Zohar, elaborou os estudos descritivos da tradução e tampouco da "virada cultural" preconizada por Mary Snell-Hornby, André Lefevere e Susan Bassnett, estudiosos como Theo Hermans, Jean-Marc Gouanvic, Michaela Wolf, Hélène Buzelin, Anthony Pym, Daniel Simeoni, Andrew Chesterman, Pascale Casanova, Johan Heilbron e Gisèle Sapiro são alguns dos que se propuseram a cultivar e a desenvolver a agenda sociológica no campo dos Estudos da Tradução, germinada pelos trabalhos seminais de James Holmes e Itamar Even-Zohar. A partir deste ponto, cumpre que se estabeleçam as devidas interligações entre a sociologia lato sensu e os Estudos da Tradução. Construídas essas pontes cognitivas e conceituais, espera-se obter uma noção mais coesa do que hoje se denomina por

\footnotetext{
${ }^{22}$ the complex of problems clustered round the phenomenon of translating and translations
} 
sociologia da tradução. Assim sendo, falar de uma sociologia da tradução implica necessariamente falar do pensamento de Pierre Bourdieu, da teoria ator-rede elaborada por Bruno Latour e Michel Callon e da teoria sistêmica de Niklas Luhmann. Uma vez tendo por objetivo investigar a função social da tradução, é fundamental apresentar esses pilares teóricos que sustentam a abordagem aqui em foco.

Do pensamento de Bourdieu, de longe o que mais forneceu elementos para uma sociologia da tradução, destacam-se os conceitos de campo, capital simbólico, habitus e illusio. Como argumenta Jean-Marc Gouanvic (2005, p. 151), dos quatro conceitos supracitados, é o de “campo” que ocupa uma posição central na configuração conceitual de Bourdieu, visto que é em torno dele que os demais orbitam, sendo o campo literário o que constitui o objeto de análise da pesquisa aqui desenvolvida. Por campo, então, entende-se ser o meio por onde circulam e atuam indivíduos que compartilham, se não as mesmas atividades, tarefas afins ou complementares, e que, justamente por isso, segundo Bourdieu, vivem em constante disputa por espaço e poder. Por capital simbólico compreende-se o valor que é atribuído a um determinado agente participante de um certo campo e que é utilizado por ele como cacife para lutar por uma posição de prestígio na hierarquia ali estruturada. Habitus, por seu turno, pode ser definido como toda a experiência, toda a formação adquirida pelo agente e que compõe o "currículo" que vai lhe conferir capital simbólico; habitus, em suma, a visão de mundo do tradutor que se reflete na sua reescrita tradutória. Segundo Bourdieu, (apud GOUANVIC, 2005, p. 158-9),

o habitus, que é o princípio gerador das reações que atendem de maneira mais ou menos adequada as demandas de um determinado campo, é produto não só de uma história individual, mas também - por meio das experiências formativas da primeira infância - da história coletiva familiar e de classe” ${ }^{23}$.

Por illusio entende-se ser o pacto firmado entre leitor e obra literária quando do jogo da ficção. No campo da literatura traduzida, o tradutor precisa recriar o espaço ficcional ou a atmosfera poética engendrado(a) pelo autor do

\footnotetext{
${ }^{23}$ (t)he habitus which is the generative principle of responses more or less well adapted to the demands of a certain field, is the product of an individual history, but also through the formative experiences of earliest infancy, of the whole collective history of family and class.
} 
texto fonte de modo a proporcionar um ambiente textual/literário propício para que o mesmo pacto seja celebrado entre leitor e obra traduzida. Pelo que se pode depreender, illusio seria o resultado prático, material, concreto, manifestado no texto traduzido, do habitus do tradutor. Afinal, para conseguir causar no leitor da cultura tradutora os efeitos provocados pelo original no leitor da cultura de origem, o tradutor precisará contar ou com uma boa formação acadêmica na área, ou com uma experiência profissional considerável ao longo da qual terá desenvolvido esse feeling de recriação textual mediante o processo tradutório.

A teoria ator-rede, que encontra em Bruno Latour seu mais emblemático propositor (sem que, no entanto, desconsidere-se Michel Callon, já mencionado anteriormente), possui por objeto de análise não o campo literário sobre o qual Bourdieu lançou seu foco, mas o campo da ciência e da tecnologia. Nesse cenário laboratorial, por assim dizer, Latour detecta uma convivência entre agentes humanos e não humanos (equipamentos de toda natureza) que interagem com o propósito de produzir ciência. Para que essa interação se processe de forma eficaz e, portanto, venha a garantir a produção do ato ou do artefato científico pretendido, os agentes precisam "se traduzir", como explica Buzelin (2005, p. 197):

\begin{abstract}
A tradução suscita uma sucessão de estratégias de interpretação e de deslocamento através das quais uma ideia se transforma gradualmente num fato ou artefato científico. Esse conceito é empregado em oposição ao de "difusão", sugerindo que não há transmissão sem transformação e que [...] fatos e artefatos científicos [...] não se propagam em sociedade simplesmente, mas precisam criar seu próprio espaço por intermédio de um processo concomitante de formação de rede $^{24}$.
\end{abstract}

É sobre essa rede de agentes envolvidos no processo tradutório que o pesquisador tem que voltar a sua atenção. Isso implica, segundo Latour, lançar mão de uma perspectiva etnográfica, visto que o ato de traduzir envolve irremediavelmente questões de natureza cultural. Vale lembrar que a cultura que serve de campo de observação para Latour é a da ciência, com seu vocabulário

\footnotetext{
${ }^{24}[\ldots]$ translation evokes successive strategies of interpretation and displacement by which an idea gradually moves into becoming a scientific fact or artefact. This concept is used in opposition to that of diffusion, as a way of suggesting that there is no transmission without transformation [...] and that scientific facts and artefacts do not simply spread in society that have to create their own space by a concomitant process of network formation.
} 
próprio, muitas vezes repleto de jargões, e que, como todo e qualquer corpo lexical, passa por constantes transformações e, em razão disso, precisa ser de domínio geral por parte de seus membros/usuários. Daí a necessidade de se estar sempre traduzindo termos, estabelecendo seus significados. Assim, infere-se que esse campo é marcado por uma cultura própria, verbalizada por uma linguagem própria, por meio da qual desenvolve seus protocolos.

Ainda sobre a teoria ator-rede, Chesterman (2014) esclarece que a ideia de rede, como concebida por Latour e Callon, não possui um “centro”, e que o traço que a caracteriza sobremodo é a interdependência de seus elementos. Infere-se daí que, na rede de Latour e Callon, não há uma estrutura hierarquizada em que os agentes formadores da base possuem menor valor do que os que compõem o topo. Nesse “organismo horizontalizado", por assim dizer, não parece haver a competição que marca o campo bourdieusiano. $\mathrm{O}$ aspecto da teoria ator-rede que mais nos interessa aqui é a concepção de tradução que ela encerra: como Chesterman (2014) esclarece, a tradução que se processa na rede de agentes concebida por Latour e Callon é a tradução intralingual de que fala Roman Jakobson (2010, p. 81). Considerando-se que a rede em questão se forma pelo entrecruzamento de tarefas executadas por atores (= agentes), faz-se necessário que “cada ator precise 'traduzir' significados nos seus próprios termos a fim de se fazer entender” 25 (CHESTERMAN, 2017, p. 319). Em suma, a tradução na rede de atores de Latour e Callon é a reformulação intralinguística para fins comunicativos dada a necessidade premente de se divulgarem os avanços no campo científico/tecnológico.

O modelo sistêmico proposto por Niklas Luhmann foi trazido para o âmbito dos Estudos da Tradução por Theo Hermans (ver BUZELIN, 2013), para quem a tradução funciona como um sistema e seria, por definição, uma modalidade de ato comunicativo que ocorre entre os elementos humanos que compõem o sistema social. À semelhança da teoria de polissistemas de Itamar Even-Zohar, no modelo teórico de Luhman, a sociedade é vista como um conglomerado de sistemas que, apesar de funcionarem independentemente, tangenciam-se de forma regular e, em muitos momentos, intersectam-se

\footnotetext{
${ }^{25}$ Each actor has to "translate" into his/her own terms, in order to make sense of them.
} 
promovendo uma interação. Desse modo, como propõe Luhman (ver BUZELIN, 2013), a estrutura social é um macrossistema composto por sistemas menores: o sistema das leis, o sistema religioso e o sistema político, para citar alguns. Cada um desses sistemas é formado por subsistemas: os códigos (sistema das leis), as diversas vertentes da fé (sistema religioso) e as várias nuances políticoideológicas (sistema político).

Como informa Buzelin (2013), Luhman compreende que cada um desses sistemas funciona por meio de atos comunicativos. Em razão disso, penso ser legítimo inferir que os códigos e os documentos que circulam no meio jurídico registram textualmente as normas que disciplinam a conduta dos indivíduos que vivem em sociedade; os rituais religiosos, bem como os livros tidos como sagrados num determinado sistema social, levam aos seus cidadãos a palavra da fé e estabelecem seus dogmas; os discursos (expressos por escrito ou oralmente), assim como as plataformas políticas dos partidos, informam como os representantes eleitos pelo povo estão conduzindo as questões que afetam aquela comunidade. De forma similar, a tradução é vista como uma ferramenta de comunicação, pois possibilita o acesso a um texto, independentemente da modalidade tradutória, como estabelecidas por Roman Jakobson (2005, p. 81): interlingual, intralingual ou intersemiótica. Por ter uma função tão específica, a tradução forma um sistema à parte assim como propõe Hermans (ver BUZELIN, 2013). Autônomo e complexo, o sistema da tradução se nutre não só da transformação linguística, mas também dos elementos que a cercam e cuja existência se dá tão-somente em função e em razão dessa proximidade: o que se diz sobre a tradução, os paratextos que se elaboram sobre a tradução e toda a pesquisa que se empreende sobre o fenômeno tradutório. Por ter como principal função representar os interesses de todos os demais sistemas formadores do sistema macro, que é a sociedade, o sistema formado pela tradução pouco se diferencia dos demais. Em outras palavras, os eventos tradutórios se pulverizam pelos demais sistemas e, com isso, fazem-se presentes em quaisquer outros. A natureza extremamente abstrata do modelo sistêmico de Luhmann, argumenta Sergei Tiulenev (apud BUZELIN, 2013, p. 189), é o que o torna aplicável aos Estudos da Tradução. 
Vistos até aqui os modelos teóricos oriundos da sociologia geral aplicáveis à tradução, passaremos agora a discutir os conceitos que ajudarão a promover a interligação entre sociedade e tradução e entre sociologia e os Estudos da Tradução. Em razão de estabelecerem essa interconexão conceitual, Andrew Chesterman (2009) os denominou "conceitos-ponte".

\section{5 .2}

\section{Os "conceitos-ponte" de Andrew Chesterman}

Se Anthony Pym clama por um foco analítico sobre os agentes da tradução, denominados por ele de “mediadores”, a grande questão para Andrew Chesterman, em se tratando da tradução como prática e como objeto de análise de pesquisa acadêmica, reside na importância social da atividade tradutória. Chesterman alega que, para que a pesquisa sobre a tradução vá além de uma abordagem descritiva e para que se tragam à cena observada elementos contextuais, é necessário que se comprove o papel social desempenhado pela tradução. Para dar sustentação à sua proposta, Chesterman invoca onze conceitos que ajudarão a jogar luz sobre as áreas de interseção entre os Estudos da Tradução e a sociologia. Provavelmente por uma questão nocional e didática, Chesterman agrupa os onze conceitos da forma que se segue: causalidade; prática (tradutória), discurso e habitus; normas, briefing e estratégias; reação, resposta e repercussão e convergência (consilience).

(a) Causalidade: conforme argumenta Chesterman, dos três modelos metodológicos utilizados em Estudos da Tradução - comparativo (nível textual), processual (nível cognitivo) e causal (nível relacional, por assim dizer) - é este último que apresenta o espectro analítico mais ampliado e, justamente por isso, está intimamente ligado à sociologia da tradução. Segundo ele, o modelo causal, como a própria denominação já sugere, tem por objetivo mostrar a relação de causa e efeito ensejada pela tradução, inserindo-se na ideia de "causa” os fatores que influenciam a feitura do texto traduzido e, dentro do bojo nocional de "efeito", contempla-se o quanto aquela tradução influenciou o público leitor a que se destinou. Como evidência concreta do efeito da tradução, pode-se citar a aferição de 
qualidade feita por certificados internacionais como o ISO, DIN e CEN a que o trabalho tradutório também se submete. Sobre esse aspecto, alega Chesterman que

[essas entidades de padronização] especificam aspectos do processo tradutório em detalhes partindo do princípio de que, se todas as etapas forem executadas "corretamente", o produto final será de "qualidade aceitável", conforme os padrões [de qualidade estabelecidos por essas entidades]. ${ }^{26}$ (CHESTERMAN, 2007, p. 174)

A propósito de discorrer sobre o “conceito-ponte" de causalidade, Chesterman, assim como o fez Pym (2006), traz à baila a figura do tradutor que, na condição de agente humano da tradução (mediador), constitui-se num dos mais importantes agentes do processo de traduzir ${ }^{27}$. Desse modo, Chesterman afirma que

todas as causas externas à tradução, bem como suas características peculiares, só exercem alguma força causal se canalizadas ou filtradas pela mente do tradutor. Pressões e valores de natureza cultural e sociológica, assim como normas e instruções, só produzirão efeito no texto alvo por intermédio da agentividade do tradutor $^{28}$. (CHESTERMAN, 2007, p. 176)

(b) Prática, discurso e habitus: assim como toda atividade humana, a tradução revela através de seu processo de feitura traços característicos de seu agente: a seleção vocabular, a forma de elaborar a estrutura frasal, além de omissões ou acréscimos textuais que o tradutor julgou convenientes, por exemplo. Todos esses elementos constituintes do texto traduzido são produto do trabalho intelectivo do tradutor que, por seu turno, é influenciado pelo contexto em que se insere. Esse produto do trabalho mental do tradutor, por sua vez, poderá trazer para a cultura alvo elementos novos, contribuindo, assim, para o seu enriquecimento. O

\footnotetext{
${ }^{26}$ International ISO, DIN and most recently CEN standards [...] specify aspects of the translation process in great detail, on the assumption that if the various phases are carried out "correctly, the final product will be of "acceptable quality", according to these standards.

${ }^{27}$ O conceito de "processo de traduzir" elaborado por Chesterman refere-se às etapas de produção de um título traduzido contemplando todos os agentes participantes, diferindo-se da abordagem processual de que trata James Holmes, esta de cunho cognitivo.

${ }^{28}$ [...] all external causes of translation, or particular features in translation, only exert a causal force by virtue of their being channelled or filtered through the translator's mind. Cultural and sociological pressures and values, norms and instructions, only have on the target text via the translator's agency.
} 
“discurso da tradução”, como elucida Chesterman, é outro conceito que evidencia o papel social que o texto traduzido desempenha. Considerando o desgaste semântico que o termo "discurso" vem sofrendo, para efeitos de uma sociologia da tradução, Chesterman o define como "o uso contextual da língua” ${ }^{29}$ (2007, p. 176). Sob uma ótica mais pragmática, para o autor, o “discurso sobre a tradução” ${ }^{30}$ seria o que se diz sobre a tradução, ou seja, todo e qualquer texto (escrito ou oral) que se produza a respeito da tradução e que venha auxiliar a compor uma imagem pública do tradutor como profissional. Dentre os autores desses textos sobre a tradução, incluir-se-iam críticos e também editores que determinariam o viés discursivo que um dado texto traduzido deveria assumir. Habitus, como já dito anteriormente (2007, p. 5), pode ser definido como todo o arcabouço de conhecimento e experiência que possui o tradutor. Citando Moira Inghileri, Chesterman resume o conceito de "habitus do tradutor" como sendo algo adquirido por intermédio de práticas sociais empreendidas com tal regularidade que acabam por fazer parte do próprio indivíduo. Como se vê, as ideias de habitus e de prática formam um binômio, uma vez que estabelecem entre si uma relação de causalidade mútua. Desse modo, analisar a prática tradutória, alerta Chesterman, implica necessariamente trazer à baila muitos aspectos sociológicos presentes na cena observada:

A análise da prática [tradutória] contempla muitos aspectos sociológicos dos eventos tradutórios [...] e tem por foco como tradutores trabalham, como organizam seu tempo, [como se dá] a dinâmica do local de trabalho, [como interagem] com outros membros da equipe e experts, [como se utilizam de] de recursos, [como gerenciam] projetos, [quais são os] padrões de controle de qualidade [a seguir] e outros elementos. Portanto, [uma análise da prática tradutória] cobre um campo mais amplo do que a análise do discurso, que volta [...] sua atenção [quase que unicamente] para o uso da língua em vez de ações num sentido mais amplo. ${ }^{31}$ (CHESTERMAN, 2007, p. 177)

\footnotetext{
29 "language use in context".

30 “discourse of translation".

${ }^{31}$ [...] Practice analysis covers many sociological aspects of translation events. It focuses on what people (translators) do: how they organize their time, their workplace procedures, their interactions with other team members or experts, their use of resources, project management, quality control procedures, and so on. It thus covers a wider field than discourse analysis, which focuses mainly on language use rather than actions more generally.
} 
(c) Normas, briefing e estratégias: falar de normas, briefing e estratégias confere à análise da tradução um contorno mais mercadológico, visto que, em função desses conceitos, a tradução é vista como um produto comercial. Como já havia observado Gideon Toury (1995), a produção de um texto traduzido é uma ação que vem a preencher uma lacuna na cultura tradutora. Uma vez vertido para o vernáculo da cultura de chegada, esse produto cultural circulará pelos meios a que aquela tradução se destina e essa circulação normalmente se faz por meio da relação de compra e venda. Por normas, como já apresentado no capítulo 1, seção 1.2, deste trabalho, Chesterman (2007, p. 178) compreende o conjunto de valores e ideias estabelecidos tacitamente entre os sujeitos participantes de um determinado campo, entendido aqui no sentido bourdieusiano. Desse modo, a confecção de um texto traduzido se perfaz em observância a critérios de produção e padrões de qualidade. Encarar a tradução como produto comercial envolve necessariamente aspectos da mesma natureza. Se a tradução de um texto for encomendada, decerto o cliente em questão tem um propósito, uma intenção. Assim sendo, para satisfazer essa necessidade, o cliente passará ao prestador do serviço (o tradutor ou o editor) uma série de informações que nortearão os termos pelos quais o “contrato de serviço” deverá se pautar: o tipo de texto fonte, o objetivo da tradução, o prazo para a entrega do texto traduzido, o valor a ser pago pelo serviço (se por palavra, se por lauda), para citar algumas. Assim, para uma análise sociológica da tradução, o conceito de briefing é relevante ${ }^{32}$. Ao se deparar com um texto a ser traduzido, o tradutor fará uso de todo o seu cabedal de conhecimento e de experiência profissional e pessoal para dar cabo da tarefa de modo a confeccionar um produto final que atenda às expectativas e aos padrões de qualidade estabelecidos pelo cliente. Assim, ele empregará as estratégias a seu dispor para atingir esse objetivo. Esses recursos de produção textual, no caso da tradução, são denominados “estratégias globais”, visto que regem a tradução como um todo. Dessa

\footnotetext{
${ }^{32} \mathrm{O}$ conceito de briefing passa a ser central, caso se adote a teoria do escopo (Skopostheorie) como abordagem teórica. Segundo essa teoria, criada pelo linguista alemão Hans Vermeer, a tradução (assim como a interpretação) deve levar em conta a finalidade dos textos fonte e meta.
} 
forma, ao verter um texto escrito na língua A num texto escrito na língua B, argumenta Chesterman (2007), o tradutor precisará fazer escolhas como as elencadas abaixo.

- Imprimir no texto traduzido o máximo possível de traços da cultura tradutora (domesticar, no sentido venutiano) ou, o inverso, manter o máximo possível de traços da cultura traduzida (estrangeirizar)?

- Usar notas explicativas sempre que julgar que o leitor poderá ficar confuso perante algum elemento de estranheza contido no texto de origem? (Muitas vezes, essa é uma decisão da editora, na condição de “agente de patronagem”, como propõe André Lefevere. Essa função poderá ser exercida por qualquer espécie de instituição religiosa, política ou acadêmica, veículos de comunicação emissora de televisão, produtores de jornais e revistas e, mais contemporaneamente, canais, blogs e sites na internet - e as tradicionais editoras de livros que promovam a produção e/ou adaptação de textos, incluídos aí os traduzidos).

- Como lidar com estruturas sintáticas extremamente longas, de difícil processamento, ou pouco usuais na língua de tradução: efetuar eventuais ajustes/alterações ou reproduzi-las tal como estão no original?

- Como adaptar metáforas quando não há correspondente na cultura tradutora?

O que vai modular as escolhas do tradutor serão as instruções para a realização do projeto tradutório (briefing), considerando ainda que há escolhas feitas que vão além da vontade consciente do tradutor.

(d) Reação, resposta e repercussão: como já dito anteriormente, a tradução é o resultado da confluência de uma série de fatores. No entanto, a tradução também pode ser vista como uma causa em si mesma, ou seja, como uma fonte de efeitos produzidos na mente de quem a consome. Em razão dessa visão dualista, por assim dizer, parece ser legítimo afirmar que a tradução, por um lado, pode ser encarada como um produto ocasionado pela concorrência de elementos causais (desde a lacuna que 
possa vir a preencher na cultura meta até os itens culturais da cultura fonte que vem a fornecer à cultura tradutora), e, por outro, pode ser vista como uma mola propulsora de efeitos. O primeiro efeito elencado por Chesterman é de caráter cognitivo e afeta o leitor da obra traduzida quando este se depara, por exemplo, com alguma construção sintática totalmente dissonante na língua alvo. Esse efeito é classificado por Chesterman como "reação”. O teórico esclarece, então, que a tradução, uma vez entendida como ato comunicativo, interfere na cognição de quem a lê, podendo essa reação se manifestar em três situações: 1) perante qualquer estranheza no texto traduzido, o leitor, independentemente de conhecer o idioma fonte, será levado a deduzir que o tradutor cometeu algum deslize; 2) no caso de o leitor dominar a língua de origem, ele terá condições de avaliar as soluções encontradas pelo tradutor; 3) o leitor se sentir compelido a ler outras obras do autor ou gênero traduzido. Essas três situações citadas por Chesterman à guisa de exemplificação ocorrem no nível do indivíduo, no cérebro de cada leitor no ato de leitura de uma tradução. Se, porém, a tradução produzir efeitos cognitivos num número significativo de leitores, ou seja, se muitos leitores manifestarem algum tipo de reação quanto a um determinado texto traduzido, formar-se-á uma "reação coletiva” que Chesterman nomeia "resposta”. Conclui-se daí que a reação se dá no nível do indivíduo, ao passo que a resposta ocorre no nível coletivo, ou melhor, a resposta é o somatório de um certo número de reações. Se, como alega o teórico, a reação se manifesta no nível do indivíduo e a resposta, no do coletivo, a repercussão, por sua vez, dá-se na esfera cultural. Assim, se uma obra traduzida consegue obter expressiva aceitação por parte da cultura de chegada a ponto de conquistar um lugar no cânone de literatura traduzida do sistema receptor, é sinal, segundo Chesterman, de que aquela obra provocou uma repercussão, ou seja, a sua versão traduzida para o vernáculo em questão conquistou um lugar dentre as obras canônicas pertencentes ao sistema de literatura traduzida em operação dentro daquele sistema literário. Outro indício da repercussão que uma obra traduzida pode provocar e que Chesterman 
identifica é o caso de uma renovação estética que chega ao sistema literário receptor via tradução. Uma outra possibilidade de repercussão vislumbrada pelo estudioso é quando a língua alvo sofre modificações em razão de uma determinada tradução. Neste caso em especial, deduz-se que não será a tradução de uma obra literária unitariamente que causará esse efeito, mas, sim, a tradução de uma série, de um gênero ou da obra de um autor que conseguirá ocasionar tamanha capilaridade. Outra situação aventada pelo teórico é a da mudança nas normas e práticas tradutórias ensejadas por uma obra em especial. O que se pode concluir a partir desta última situação em especial é que uma tradução, para afetar o conjunto de normas e práticas tradutórias, deverá ter por texto fonte algo inusitado a ponto de ensejar essas mudanças, ou seja, um texto que, pela sua significativa singularidade poetológica e/ou temática, quebrou os paradigmas tradutórios. O último exemplo de repercussão mencionado por Chesterman é o da mudança de percepção em relação a certos estereótipos culturais. O que se pode deduzir deste cenário em particular é que, ao escolher uma obra para tradução, obra esta em que se desfaz a imagem equivocada e imbuída de preconceito em relação a uma cultura estranha/estrangeira, a sua tradução será o instrumento necessário para que a cultura receptora possa mudar essa visão de forma efetiva. No afã de ilustrar por meio de uma imagem os conceitos-ponte aqui discutidos, identifico uma similaridade entre a ocorrência deles e o movimento de uma pedra que, ao ser arremessada sobre a superfície da água, forma uma sequência de ondas. A pedra simbolizaria a tradução de uma obra estrangeira lançada no sistema literário receptor, que, por sua vez, estaria representado pela água. Uma vez em contato com esse meio, a obra traduzida, assim como a pedra jogada à água, provocaria uma propagação de ondas, sendo que as primeiras a serem formadas estariam mais próximas à tradução (pedra) e representariam a reação de cada leitor. À medida que essa reação vai se propagando, mais ondas são provocadas, formando, assim, a resposta. Essas ondas vão alastrando ampliando cada vez mais o seu espectro, movimento em que identifico a formação da repercussão, que se dá, como conceitua Chesterman, no nível da cultura. 
Desse modo, ao vislumbrar a imagem descrita acima, identifico um movimento centrípeto que, provocado pela obra traduzida, tem seu primeiro efeito sentido pelo leitor individualmente e, num crescendo, atinge um grupo maior de leitores e, num último possível estágio, chega ao estrato da cultural, como tento demonstrar no diagrama abaixo. 


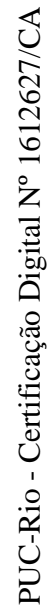

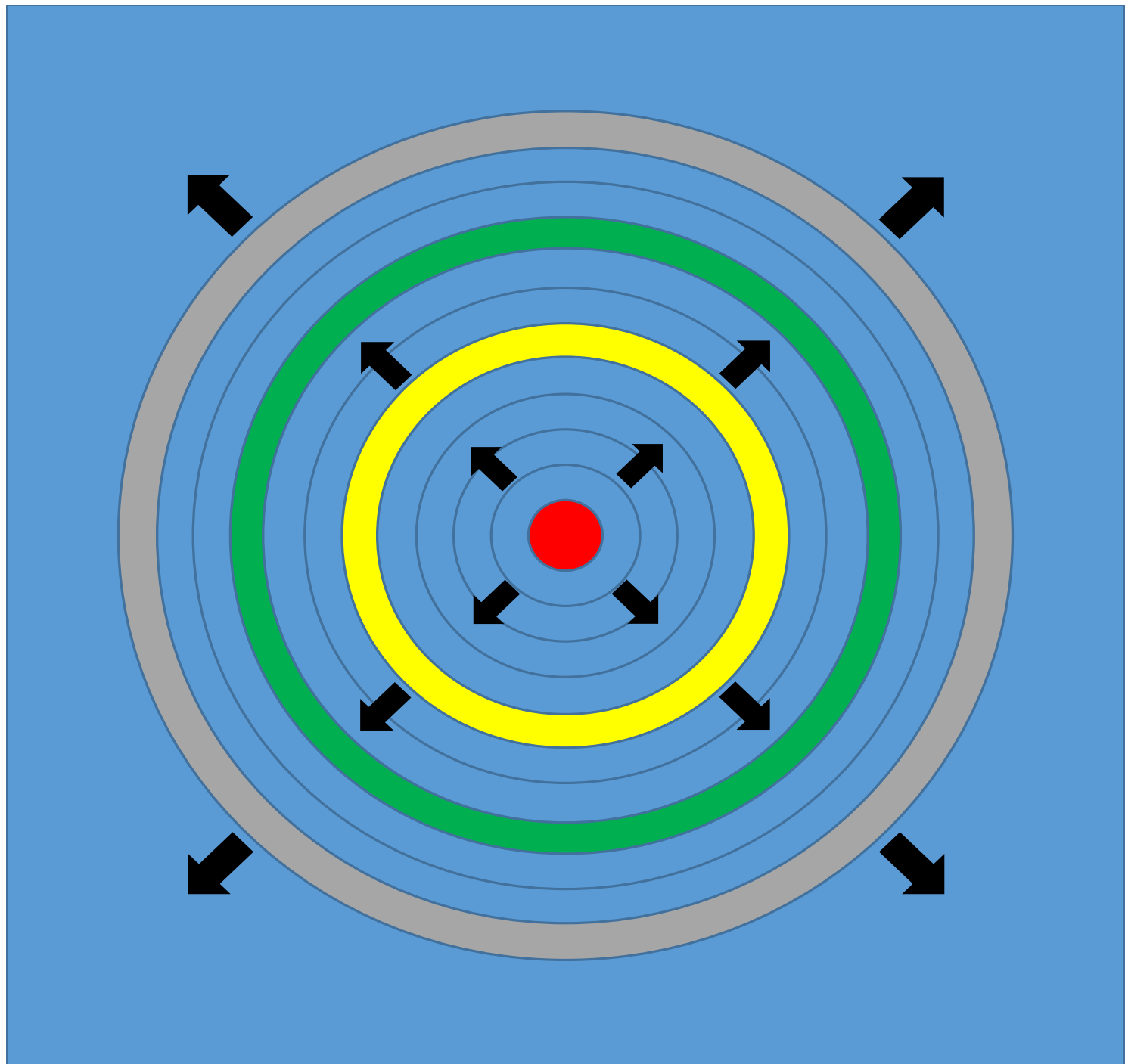

(Fonte: diagrama elaborado pela autora)

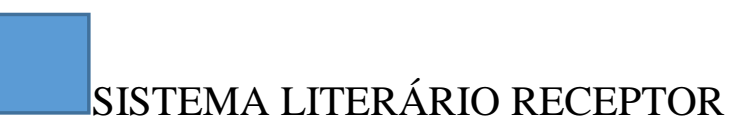

TRADUÇÃO
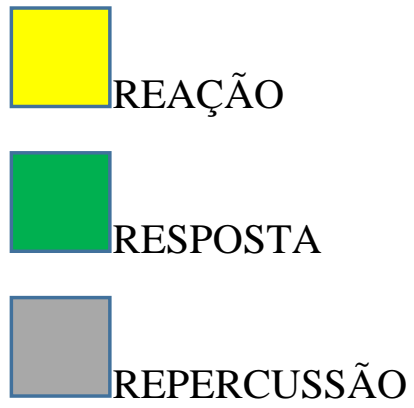
(e) Convergência (consilience): o conceito de consilience, aqui traduzido por “convergência”, e da forma como o emprega Chesterman, vem para marcar a natureza multidisciplinar dos Estudos da Tradução, sobretudo, da sua abordagem sociológica. Defende Chesterman que, ao contrário do que possa supor o senso comum, o hibridismo epistemológico da área é onde reside a sua consistência, pois "na condição de interdisciplina, os Estudos da Tradução modernos se autodefinem como uma nova tentativa para ultrapassar as barreiras na busca por um entendimento mais profundo da relação entre textos, línguas, sociedades e culturas”33 (CHESTERMAN, 2007, p. 181).

A exemplo do que fez Chesterman, que estabeleceu uma conexão entre a sociologia geral e alguns dos conceitos desenvolvidos no âmbito da sociologia da tradução por intermédio dos seus “conceitos-ponte”, tentarei agora estabelecer também uma ligação entre esses mesmos conceitos e o processo aqui investigado, ainda que de forma não detalhada como pretendo fazer mais adiante neste trabalho. Visto que, neste ponto, tenho por finalidade promover a interconexão entre os conceitos-ponte de Chesterman e o processo de publicação de obras traduzidas, observado sob uma perspectiva prática, não considerarei aqui o conceito de "convergência" por se restringir ao âmbito teórico. Assim sendo, entendo que, ao importar uma obra estrangeira para a tradução, as editoras brasileiras o fazem para atender a uma demanda mercadológica; em contrapartida, essa tradução não só produzirá efeitos no público leitor da cultura receptora, mas também vai se somar ao repertório literário do sistema receptor, podendo-lhe introduzir novos gêneros e uma nova concepção estética de texto literário. No que tange ao trio de conceitos “prática, discurso e habitus”, percebo estar intimamente ligado à atividade central do processo de publicação de obras traduzidas: a elaboração do texto traduzido em si. A obra traduzida que será lida (consumida) pelo leitor da cultura receptora é fruto da atividade laboral do tradutor e do(s) revisor(es)

\footnotetext{
${ }^{33}$ As an interdiscipline, modern translation studies announces itself as a new attempt to cut across boundaries in the search for a deeper understanding of the relations between texts, languages, societies and cultures.
} 
que, no momento em que tecem (o tradutor) e aperfeiçoam (revisor/es) o texto traduzido, deixam nele as marcas de sua experiência pessoal, profissional e, em muitos casos, acadêmica. Em suma, o tradutor deixa no texto traduzido as suas digitais de sujeito. Se, para traduzir um romance estrangeiro, o tradutor se vale das recomendações da editora contratante para orientar o seu trabalho, identifica-se nesse ato o terceiro grupo de conceitos-ponte proposto por Chesterman: "normas, briefing e estratégias". Esse texto traduzido e revisado, elaborado à luz da expertise do tradutor e do(s) revisor(es), tem um público alvo. É a esse leitor final, seja o crítico literário/especializado ou o leitor comum, que se refere o último trio de conceitos-ponte, com os quais Chesterman denomina a forma como essa obra traduzida é recebida na cultura de chegada, considerando três níveis: pessoal (reação), coletivo (resposta) e cultural (repercussão). Desse modo, sempre que possível, procurei observar nos relatos dos participantes como esses conceitos-ponte se manifestam na prática, cotejando essa manifestação pragmática, por assim dizer, com a conceituação teórica de cada um deles elaborada por Chesterman.

\section{6 \\ O campo editorial: uma perspectiva pragmática da tradução como prática social}

Até o presente momento, todo o inventário teórico utilizado para a elaboração deste trabalho aponta indubitavelmente para a existência de um papel social desempenhado pela tradução. Em busca de uma evidência mais palpável, mais cotidiana, mais facilmente identificável no mundo concreto, propõe-se observar agora o que Pierre Bourdieu chamou de “campo editorial”.

A socióloga francesa Gisèle Sapiro (2008) abre seu artigo “Translation and the field of publishing: A commentary on Pierre Bourdieu's 'A conservative revolution in publishing'” ressaltando a importância do papel desempenhado tanto por editores quanto por casas editoriais para uma abordagem sociológica da tradução. Falar do campo editorial, entendido aqui no sentido bourdieusiano, implica necessariamente falar do aspecto mercadológico da produção de textos, 
sejam escritos no vernáculo ou importados para a tradução. No caso destes, a rede de agentes e atividades se amplia consideravelmente e ganha uma complexidade maior, uma vez que se estabelece aí a comercialização de um produto peculiar, de natureza cultural, entre culturas de línguas diferentes.

O teórico holandês Johan Heilbron apresenta essa visão mercadológica e editorial ao entender “[a] tradução de livros como um sistema cultural mundial”34. (HEILBRON, 2010, p. 304; grifo meu). É interessante notar que Heilbron emprega a palavra "livros", vocábulo que nos remete à imagem concreta de um produto com características físicas próprias, sendo no formato impresso ou no digital. Cada cultura, representada por sua língua, produz suas “commodities" literárias e oferece-as no mercado internacional. Assim como no cenário econômico lato sensu, as culturas de línguas consideradas mais centrais exportam mais literatura e, consequentemente, são mais traduzidas. As mais periféricas, por seu turno, importam mais e, por conseguinte, traduzem mais. Assim, a troca entre literaturas e suas respectivas traduções no sistema cultural internacional se dá de forma assimétrica. A mesma visão de tradução como ferramenta crucial que viabiliza a troca de produtos culturais - livros incluídos - entre culturas de línguas diferentes tem a pesquisadora Pascale Casanova. Se, por um lado, Heilbron apresenta um modelo teórico à semelhança da teoria de polissistemas de EvenZohar (os termos “centro” e "periferia”, bem como os conceitos que encerram, são mantidos em sua proposta), Casanova opta pelos sintagmas "língua dominante” e "língua dominada”, deixando indubitável sua orientação marxista na escolha dos adjetivos “dominante” e “dominada”. Predileções terminológicas e orientações ideológicas à parte, o certo é que tanto Heilbron quanto Casanova concordam num ponto: a posição ocupada por uma língua no panorama mundial da tradução não é estática. Seja no cenário conflitante e marcado pela ideia de luta por poder idealizado por Casanova ou na estrutura hierarquizada elaborada por Heilbron na sua proposta teórica, línguas outrora dominantes cederam a outras o seu lugar de prestígio. Até que essa mudança de órbita de fato aconteça, as culturas periféricas, importadoras e tradutoras de literatura estrangeira encontram inúmeras barreiras para migrar da periferia para o centro da literatura traduzida. O clássico exemplo

\footnotetext{
${ }^{34}$ Book translations as a cultural world system
} 
dessa troca de posições tem por "personagens” o francês, antes a mais traduzida, e o inglês, alçado à categoria de língua franca a partir do fim da Segunda Guerra Mundial.

A análise mercadológica e editorial empreendida por Heilbron e Casanova são fruto da ampliação da objetiva analítica que os Estudos da Tradução passaram a adotar a partir de meados da década de 1970, que permitiu que o fenômeno tradutório fosse examinado sob um ângulo contextual. Assim, paralelamente ao estudo das transformações linguísticas que caracterizam a tradução interlingual, fatores de natureza situacional, por assim dizes, passam a ser tema de interesse dos pesquisadores da área. Dentre os aspectos contextuais para os quais os Estudos da Tradução passaram a voltar seu foco, pode-se citar o processo de elaboração do texto traduzido, entendido como uma cadeia de agentes que atuam e tarefas que se executam para que essa confecção se conclua. É esse processo, essa cadeia de agentes que interagem entre si e essas tarefas que se entrecruzam para executar a tradução que se pretende analisar e discutir aqui. Em suma, o que pretendo investigar é como se processa a cadeia produtiva da tradução, ou, nos termos de Chesterman (2014), observar como se tece a sociologia do traduzir, como veremos mais detalhadamente em seguida. No que se refere à metodologia, optou-se por realizar entrevistas com agentes em franca atuação no mercado editorial, conforme informado na introdução deste trabalho.

A estrutura concebida por James Holmes para descrever o campo disciplinar dos Estudos da Tradução foi representada por Toury de acordo com o diagrama abaixo: 


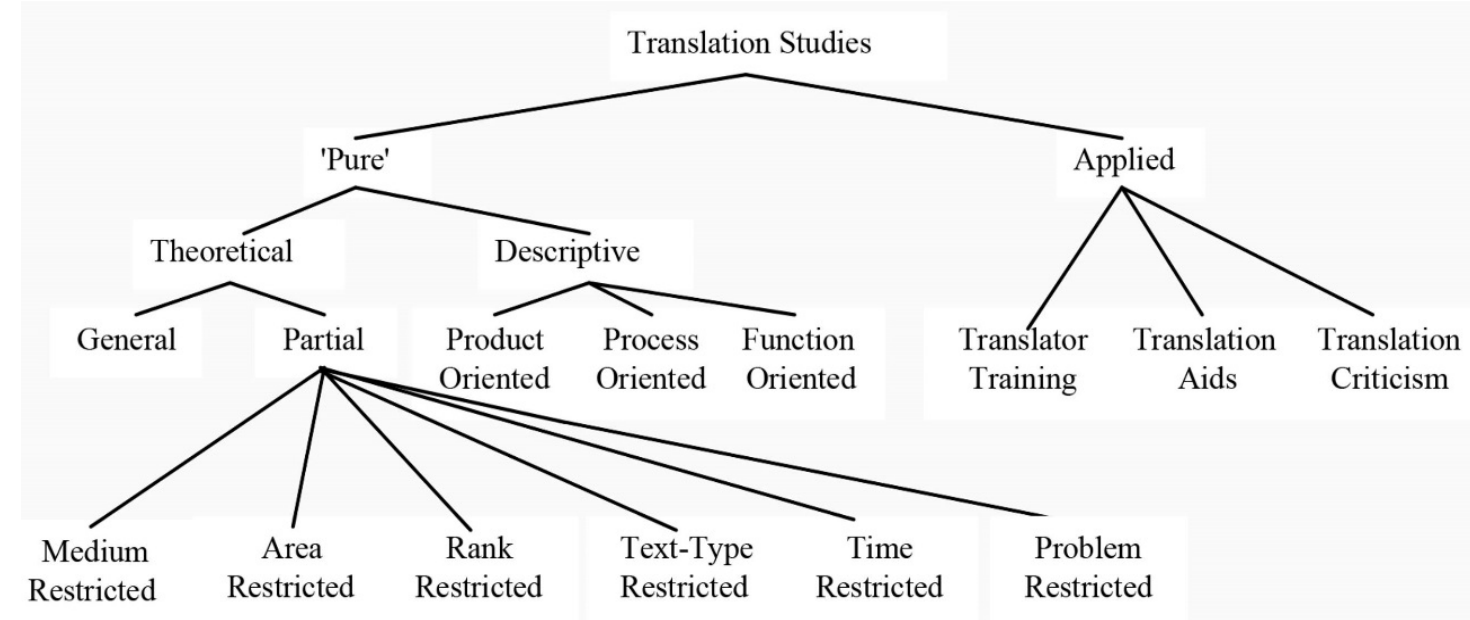

Figura 1 (Fonte: Toury, 1995, p. 10).

Note-se que o ramo descritivo se apresenta tripartido, sendo que cada ramificação se refere especificamente a um objeto de estudo: produto da tradução, processo da tradução e função da tradução. O processo a que alude Holmes em seu mapa, alerta Chesterman (2014, p. 36), refere-se à operação cognitiva que se verifica na mente do tradutor quando do ato tradutório, não se tratando, portanto, do aspecto sociológico da tradução. A sociologia do processo da tradução, como propõe Chesterman (2014, p. 37; grifos meus), definir-se-ia como:

o estudo das fases do ato tradutório: práticas de tradução e procedimentos de trabalho, procedimentos de controle de qualidade e processo de revisão, a cooperação em equipes de tradução, elaboração múltipla, relações com outros agentes, incluindo o cliente, e assim por diante.

Ao definir a tradução como “ato”, Chesterman constrói um cenário cujo traço mais distintivo parece ser o da práxis. Além de se conceituar como performance, a tradução, cumpridas todas as etapas de sua confecção, resulta num produto que, como tal, está sujeito a um controle de qualidade, como já dito anteriormente. Todas essas operações performáticas são empreendidas por agentes que, lançando mão de procedimentos técnicos, estratégias e conhecimento, articulam-se de forma cooperativa para oferecer ao cliente, agente em cujo benefício toda essa cadeia se processa, um produto idealmente de alta qualidade. Toda essa malha de atividades, agentes, procedimentos, relacionamentos e controle de qualidade são elementos (humanos e não humanos) constituintes do processo de traduzir como proposto por Chesterman. Desse modo, ele identifica na definição de tradução como prática o ponto de partida ideal para se desenvolver 
uma "sociologia do traduzir" (the sociology of translating). É interessante notar que o emprego do infinitivo em português e do gerúndio em inglês não só denotam inequivocamente a ideia da "atividade tradutória em execução”, como também, nas línguas aqui consideradas, marcam morfologicamente o que diferencia a "sociologia do traduzir”, cujo objeto de análise é mais específico (o processo de feitura da tradução), da "sociologia da tradução" (a tradução como fenômeno propriamente), que volta o seu foco investigativo para algo mais abrangente. Chesterman (2017, p. 315) alega que a ideia de "prática envolve pessoas (normalmente mais de uma) e que esse fato, por si só, nos leva um passo além do foco no tradutor como agente isolado" ${ }^{35}$. Associar a ideia de "agente da tradução” apenas à figura do tradutor, pelo que se pode inferir, é um reflexo da noção de tradução tão-somente como a transformação linguística de um texto escrito numa determinada língua em um texto (re)escrito em outra, atividade executada por um único agente.

No afã de trazer para o âmbito da sociologia da tradução a noção de "prática”, Chesterman recorre a Runciman, que vê a práxis como uma "ação recíproca” (2017, p. 316), e não se pode conceber uma ação recíproca com um só elemento. Assim, falar da mutualidade de uma prática social é envolver necessariamente, pelo menos, dois elementos. Pensar nessa coparticipação é pensar forçosamente em regras disciplinares que nortearão essa atividade conjunta. A visão de “prática social” desenvolvida pelo filósofo britânico Alasdair MacIntyre, como mostra Chesterman, repousa sobre a ideia de "atividade humana cooperativa”, ou seja, um grupo de indivíduos que se associam para executar uma atividade com um único fim: obter um resultado bem-sucedido. Dentre os exemplos citados por MacIntyre, estão práticas esportivas como o xadrez e o futebol, a arquitetura, as atividades agrícolas, a medicina, a política, a música e a pintura. Chesterman sugere que nesse grupo se inclua também a tradução. Como se pode constatar, o ambiente descrito por MacIntyre é diferente do observado por Pierre Bourdieu. Enquanto este identifica uma constante tensão em virtude das relações de poder, aquele detecta uma rede de cooperação com um objetivo comum: a excelência do produto confeccionado pelos agentes envolvidos numa

\footnotetext{
${ }^{35}[\ldots]$ a practice involves people (usually more than one): this in itself takes one step up from a focus on a translator as a single-agent.
} 
determinada cadeia produtiva. No dia a dia da indústria editorial, porém, pode-se constatar a coexistência do "espírito cooperativo" identificado por MacIntyre e do “ambiente competitivo" detectado por Bourdieu. A articulação pacífica descrita pelo teórico escocês se concretiza por intermédio da ingerência do editor, que personifica, então, o agente de “patronagem”. Ao mesmo tempo, pode-se revelar a tensão observada por Bourdieu, por exemplo, naquele revisor que, desejoso de traduzir para a casa editorial, tenta interferir além do necessário no texto do tradutor, na tentativa de mostrar melhores soluções tradutórias. Vale lembrar que a tradução é uma atividade que, além de oferecer melhor remuneração se comparada ao copidesque, também possibilita uma maior projeção profissional tanto no espaço interno da editora, quanto no panorama editorial como um todo.

Chesterman prossegue abordando a concepção de "prática social" desenvolvida por MacIntyre, alegando que o pensador escocês frisa que as atividades executadas coletivamente, ou seja, as práticas sociais, formam “um sistema institucionalizado de conduta social, em que tarefas são executadas por atores que desempenham papéis sob condições contextuais, dentre as quais se inclui a concentração de esforços para se obter qualidade” ${ }^{36}$ (CHESTERMAN, 2017, p. 317). Ao identificar o caráter institucional das práticas sociais, Chesterman automaticamente nos remete ao conceito de patronagem desenvolvido por André Lefevere. No ambiente em que se empreende a tradução, verifica-se, como já dito anteriormente, uma cadeia produtiva formada por profissionais de várias áreas e não somente por aqueles que participam da confecção do texto traduzido em si. Nessa cadeia detectam-se agentes literários, editores, artefinalistas e profissionais da área comercial, por exemplo. Todos esses agentes estão interligados e têm suas respectivas atividades promovidas por alguma espécie de instituição: uma organização religiosa, política ou acadêmica, veículos de comunicação (emissora de televisão, produtores de jornais e revistas e, mais contemporaneamente, canais, blogs e sites na internet) e as tradicionais editoras de livros. Todas essas entidades encarnam a figura do "patrono", que enseja a produção e/ou adaptação de textos, incluídos aí os traduzidos, estipulando critérios de qualidade e estabelecendo um código de conduta. Ao determinar

\footnotetext{
${ }^{36}[\ldots]$ an institutionalized system of social conduct in which tasks are performed by actors fulfilling roles, under contextual conditions which include a striving for quality [...].
} 
parâmetros e protocolos, o patrono revela possuir “um componente ideológico que age restringindo a escolha e o desenvolvimento tanto da forma quanto do conteúdo” (LEFEVERE, 2007, p. 35).

Seguindo a mesma direção tomada por Chesterman, Michaela Wolf (2007, p. 15-16) atribui ao viés sistêmico e descritivo dos Estudos da Tradução a criação de um ambiente propício para uma análise sociológica do fenômeno tradutório. Partindo do princípio de que a tradução é um processo norteado pelas relações sociais, Wolf cita três teóricos que também voltaram sua atenção para esse ponto: Clem Robyns, que concebe texto fonte e texto alvo como produtos integrados ao discurso social; Annie Brisset, que argumenta que a tradução, por se tratar de uma prática discursiva, é governada por normas, ideia já defendida por Gideon Toury; e Klaus Kaindl, cujo estudo sobre a introdução do gênero quadrinhos no campo literário alemão veio a corroborar a tese de Bourdieu de que "a posição de determinado produto cultural e seu valor relativo numa determinada sociedade são responsáveis pelo ‘sucesso’ daquele produto”37 (WOLF, 2007, p. 16).

Partindo do princípio de que a tradução é uma prática social no sentido imprimido ao termo por MacIntyre, e tendo em mente que há uma cadeia produtiva a confeccioná-la, Chesterman levanta algumas questões pertinentes a esse cenário intercultural de produção coletiva. Dentre essas questões, destacamse aqui: como se selecionam os textos a serem traduzidos; quem são os atores que compõe essa cadeia; como se exerce o controle de qualidade do produto final; como se dá a relação entre esses agentes; quais são os estágios que a atividade tradutória percorre num ambiente institucionalizado. Esses e outros pontos se mostram bastante pertinentes ao objeto de análise do presente trabalho: as traduções no campo editorial. Falar do que se concebe como sociologia do traduzir, como sugere Chesterman, é falar de pesquisa de campo. É falar, portanto, da experiência de profissionais que atuam no processo aqui investigado. Conforme observado anteriormente, o Grupo Editorial Record é minha referência principal, pois foi a casa editorial que acolheu a minha pesquisa, sempre deixando canais de comunicação abertos entre mim e seus colaboradores. Entretanto, friso

\footnotetext{
${ }^{37}[\ldots]$ the position of a certain cultural product and its relative value in a given society are responsible for the product's success.
} 
estar ciente de que, no tocante às práticas editoriais, existem, entre as editoras, inúmeros pontos em comum, mas também diferenças consideráveis que impedem que se façam maiores generalizações. Por essa razão, foi preciso enfocar prioritariamente uma única editora, entrevistando o maior número possível de agentes a ela vinculados de forma a poder registrar seus procedimentos, atentando sempre para as convergências e divergências entre os modi faciendi adotados, ou seja, observando os pontos em que cada editor tem autonomia para decidir e aqueles que são norma geral da empresa. Tendo em mente essa diversidade de políticas editoriais, em setembro de 2018, foram entrevistadas as editoras Renata Pettengill e Silvia Leitão. A primeira é hoje responsável por boa parte da ficção traduzida publicada pelo grupo, incluindo o selo Record, tido como carro-chefe da editora. A segunda, por sua vez, enquanto editorou pela empresa, atuou à frente dos selos Best Bolso, Best Business e Viva Livros. Durante esses encontros, foram abordados alguns temas concernentes ao dia a dia dos agentes que transitam e, sobretudo, laboram no campo editorial. Deste ponto em diante, far-se-á uma breve incursão pelas linhas editoriais do Grupo Editorial Record para que se possa esboçar sucintamente o perfil do conglomerado de significativa e histórica atuação no mercado editorial brasileiro.

Fundada em 1942 por Alfredo Machado e Décio Abreu, a Editora Record, célula-mãe do hoje Grupo Editorial Record, iniciou suas atividades como uma distribuidora de quadrinhos e prestadora de serviços no ramo da imprensa. O texto autodescritivo disponível no site da editora conceitua a empresa como "um dos maiores conglomerados editoriais da América Latina”38, detentor de um catálogo de cerca de oito mil títulos e com uma capacidade produtiva de 40 livros por mês. No que diz respeito ao produto que confecciona, a editora declara ser sua principal característica a "bibliodiversidade”39, ou seja, a grande variedade de títulos produzidos pelo grupo que vai desde ficção, passando por material científico, até os quadrinhos, produto que marcou o início das atividades da editora. Em um dos e-mails trocados entre mim e Luciana Villas-Bôas, a hoje agente literária, que editorou para a Record por dezessete anos, informou que, até meados da década de 1990, a Record não se constituía num grupo editorial como o é atualmente. Só

\footnotetext{
${ }^{38}$ Disponível em: <http://www.record.com.br/grupoeditorial.30/07/2019>. Acesso em 30/07/2019. ${ }^{39}$ Idem.
} 
então é que Sergio Machado, à época dono da empresa, foi adquirindo outras editoras, agregando-as à Record original. Com seus nomes originais mantidos, as outrora editoras independentes juntaram-se aos selos criados originariamente como tais, formando o conglomerado editorial como hoje é conhecido. Desse modo, o Grupo Editorial Record se encontra configurado da seguinte forma:

\section{(a) Record}

Além de definir o selo Record como o "carro-chefe do grupo" 40 , o texto informativo do site oficial da empresa procura aliar o que se denominaria aqui de “cânone literário” e "gêneros contemporâneos de forte apelo comercial”. Essa fusão de gêneros parece se reificar no último lançamento $^{41}$ do selo: Macbeth, de Jo Nesbø. O título é apresentado como uma releitura da peça de William Shakespeare: “a sombria tragédia escrita pelo dramaturgo mais influente do mundo recontada por um dos maiores autores de thrillers policiais da atualidade" ${ }^{42}$ (grifos meus). Note-se o emprego do superlativo tanto para se referir ao autor da obra que serve de inspiração para essa reescrita (“dramaturgo mais influente do mundo" (grifos meus), o canônico escritor William Shakespeare), quanto para aludir ao talento narrativo do autor do título recém-publicado (“maiores autores de thrillers”, o escritor norueguês Jo Nesbø). Fundindo esses dois capitais simbólicos, a linha editorial Record imprime, a título de estratégia de marketing, uma dupla qualidade ao produto ali ofertado. O outro exemplo citado aqui é o do clássico da literatura latino-americana Cem anos de solidão, de Gabriel García Márquez, renomado autor colombiano e ganhador do Nobel de Literatura de 1982. A versão constante do site oficial do grupo trata-se de uma retradução feita por Eric Nepomuceno, sendo que a primeira versão traduzida para o português do Brasil é de autoria de Eliane Zagury, lançada pela extinta editora Sabiá e, posteriormente pela José Olympio, quando ainda uma editora independente. Um ponto a ser abordado aqui é

\footnotetext{
${ }^{40}$ Disponível em: < $\underline{\text { http://www.record.com.br/grupoeditorial_editora.asp?id_editora=1 }}$. Acesso em 15/09/2019.

${ }^{41}$ Considerando a data do acesso referia na nota anterior.

42 Disponível em: < http://www.record.com.br/grupoeditorial_editora.asp?id_editora=1. Acesso em 15/09/2019.
} 
que o tradutor do clássico de Márquez, Eric Nepomuceno, é um premiado tradutor detentor de três prêmios Jabuti (1993, pela tradução de Doze contos peregrinos, de Gabriel García Márquez, 1995, pela tradução de As armas secretas, de Julio Cortázar, e 2010, pela tradução de Cem anos de solidão, também de Márquez). Essas informações, que agregariam valor à retradução de Nepomuceno, foram omitidas no texto promocional do site. Mais uma vez, volta-se o foco para o autor e não para o tradutor, que apenas tem o seu nome citado na ficha catalográfica disponível no site e, claro, presente também no conteúdo integral do romance, nas versões impressa, em e-book ou Kindle. Um outro aspecto que despertou a minha atenção foi o critério de classificação utilizado pela editora para tipificar as obras aqui citadas. Enquanto Macbeth, de Nesbø é classificado como thriller, a obra prima de García Márquez é inserida no rol dos "romances estrangeiros”. Diante disso, parece legítimo afirmar que, notadamente no que se refere à reescrita da peça de Shakespeare, que o fator preponderante para classifica-la no site como "thriller" foi o de natureza comercial, visto que é um dos gêneros literários mais apreciados (e vendidos) no mundo todo.

\section{(b) Civilização Brasileira}

Como informado no site da linha editorial em análise, a Civilização Brasileira deu início às suas atividades em 1929, sendo adquirida pela Record em 2000. A tradicional editora, portanto, consolidou a sua identidade editorial no mercado brasileiro ao longo de mais de sete décadas. Com isso, a Record adquiriu uma empresa pronta, de perfil editorial sedimentado e conhecido pelo público leitor que, durante a sua vida de editora autônoma, consumiu seus produtos. Justamente em razão desse "rosto editorial" consubstanciado, em seu texto informativo disponível no site, o Grupo Editorial Record afirma ter-se mantido "fiel à [...] proposta original [da Civilização Brasileira]: aliar tradição e pensamento crítico" ${ }^{43}$. Dos títulos publicados sob a chancela da

\footnotetext{
${ }^{43}$ Disponível em: < http://www.record.com.br/grupoeditorial_editora.asp?id_editora=5 $>$. Acesso
} em 15/09/2019. 
Civilização Brasileira, selecionou-se um que merece destaque em especial: a edição bilíngue de $O$ vento da noite, coletânea de poesias de Emily Brontë, célebre pelo romance $O$ morro dos ventos uivantes, uma das obras mais representativas da literatura inglesa do século XIX. O vento da noite, obra citada aqui à guisa de exemplo de publicações da Civilização Brasileira, teve em seu texto descritivo no site do selo comentários elogiosos ao tradutor, o respeitadíssimo escritor brasileiro Lucio Cardoso (1919-1968), cuja obra mais famosa é o romance epistolar Crônica da casa assassinada. Assim, diz o texto:

É uma bela oportunidade de reviver o encontro entre dois grandes nomes da literatura e observar as especificidades que permeiam os processos de criação do autor e do tradutor - uma relação marcada pela sensibilidade, intimidade, escuta e delicadeza. A edição é organizada e apresentada por Ésio Macedo Ribeiro, organizador dos Diários, de Lucio Cardoso. A prestigiada tradutora Denise Bottman assina o texto de orelha ${ }^{44}$.

\begin{abstract}
Note-se que se trata de uma relíquia literária e editorial, não apenas por ser de autoria de Emily Brontë, mas também por ter sido traduzida por Lucio Cardoso. Desse modo, o texto do site celebra "as especificidades que permeiam os processos de criação do autor e do tradutor”, reconhecendo que o trabalho do tradutor, sobretudo o de tradutor de poesia, é, sem dúvida, um trabalho de criação. O que não se informa no site é se a tradução de Lucio Cardoso passou por algum trabalho de copidesque ou apenas de revisão. Atente-se também para o detalhe da menção ao nome da "prestigiada tradutora Denise Bottman [que] assina o texto de orelha”. Esse paratexto de autoria de um tradutor é mais um sinal de que a editora quer de fato valorizar a tradução e os profissionais que a praticam.
\end{abstract}

\footnotetext{
${ }^{44}$ Disponível em: <http://www.record.com.br/livro_sinopse.asp?id_livro=29354>. Acesso em 18/09/2019.
} 


\section{(c) Paz e Terra}

Fundada em 1967 por Enio Silveira, à época diretor da Civilização Brasileira $^{45}$, e por Moacir Félix, teve seu nome inspirado na encíclica papal Pacem in Terris, publicada em 1963 pelo Papa João XXIII. Silveira, então, cria uma nova editora com o intuito de veicular ideias de natureza ecumênica. Sob a chancela da hoje linha editorial Paz e Terra, que manteve o seu viés dito progressista, o Grupo Editorial Record, além das obras nacionais, traduz e publica títulos assinados por nomes de expressão no panorama cultural mundial como Eric Hobsbawn (Os trabalhadores, título original Labouring Men, traduzido por Marina Leão Teixeira Viriato de Medeiros) e, na área de ficção, Alison Pick ( $O$ trem que leva a esperança, título original Far to go, traduzido por Adriana Lisboa). Note-se que, na tradução, o título da obra de Hobsbawn, considerada de referência, seguiu bem de perto o original. Em contrapartida, o título traduzido aposto à obra de ficção de Alison Pick não guardou nenhum elemento constitutivo do título original. Essa diferença de opção quanto à versão final do texto traduzido terá sido por mera questão comercial? Ou será que, segundo as normas do campo editorial, há uma maior flexibilização quanto à tradução (ou adaptação) de títulos de obras ficcionais? Afinal, obras de referência como as de Hobsbawn, por exemplo, já consagram não apenas o seu conteúdo, mas a sua referência denominativa, por assim dizer, desde a sua cultura/língua de origem.

\section{(d) Galera Record}

Diferentemente dos selos apresentados até este ponto, editoras antes autônomas e, posteriormente, adquiridas pela Editora Record original, o selo Galera Record já nasceu com uma linha editorial do grupo. Segundo consta do site, o Galera Record foi “criad[o] em 2007 para atender ao público de 12 a 20 e muitos anos - leitores ávidos por novidades que

\footnotetext{
${ }^{45}$ É inegável a semelhança entre as descrições dos selos Civilização Brasileira e Paz e Terra, o que nos leva a detectar uma identidade de perfil das duas linhas editoriais. Seu fundador Enio Silveira certamente trouxe fortes ecos da primeira para a segunda.
} 
falem a sua língua e retratem temas com os quais se identifiquem”46 (grifo meu). No que diz respeito ao trecho aqui citado, deve-se observar na frase em destaque a preocupação da editora em atingir o maior número possível de leitores dentro do espectro etário citado. Isso equivale a dizer que há claramente aqui um objetivo de angariar um público leitor numericamente expressivo, meta que será atingida com o lançamento de títulos que abordem temas de interesse desse público, mas empregando uma linguagem acessível, contemporânea. Segundo os relatos da tradutora Raquel Zampil e da blogueira Anastácia Cabo, analisados nos capítulos 3 e 5, respectivamente, a maioria dos leitores que, fãs de autores e de gêneros literários específicos, acabam por se interessar pela tradução das obras que leem, pertence à faixa infantojuvenil. Em razão disso, parece legítimo concluir que é nesse público mais numeroso que há uma chance maior de haver uma resposta (ver Capítulo 1, subseção 1.5.2). Navegando pelo site do selo editorial ora em análise, observa-se que a grande maioria das obras publicadas com o timbre Galera Record é composta de títulos estrangeiros, o que pressupõe uma atuação intensa de tradutores nessa linha editorial.

\section{(e) Galerinha Record}

Criado três anos após o selo Galera Record, o Galerinha Record, como já denuncia o diminutivo aposto ao substantivo "galera”, tem por alvo o público infantil. Em seu catálogo figuram obras de autores canônicos da literatura brasileira, como o conto “Luciana”, de Graciliano Ramos, originalmente publicado em 1947 como parte integrante da coletânea Insônia. Dentre os títulos traduzidos, dois chamam a atenção: A pequena Alice no país das maravilhas e Quem mexeu no meu queijo? Para crianças. O primeiro se trata de uma reescrita autoral e intralingual feita pelo próprio Lewis Carroll, vinte anos após o lançamento da obra original em 1885 e que recebeu o título em inglês de Nursery Alice e, em português, o título adaptado de A pequena Alice no país das maravilhas.

\footnotetext{
${ }^{46}$ Disponível em: <http://www.record.com.br/grupoeditorial_editora.asp?id_editora=11>. Acesso em 22/09/2019.
} 
Em 2015, por ocasião da comemoração do sesquicentenário do lançamento da obra originária, Alice no país das maravilhas (Alice in Wonderland), o selo Galerinha trouxe para o Brasil uma nova edição da reescrita de Carroll, ilustrada pelo francês Emmanuel Polanco. É interessante notar que o nome da tradutora não se restringiu a uma simples menção na ficha catalográfica disponível no site. Por razões incontestes, mereceu referência elogiosa no texto descritivo da obra, pois, afinal, trata-se de uma tradução feita "pela premiada escritora Marina Colasanti"47. Mais uma vez, a chancela autoral avaliza a qualidade do trabalho tradutório. A segunda obra do selo Galerinha Record que será comentada aqui é a versão infantil do clássico do espectro da autoajuda (segundo algumas classificações, seria um livro motivacional) Quem mexeu no meu queijo?, de autoria do psicólogo norte-americano Spencer Johnson, lançado pelo selo Record e traduzido por Maria Clara de Biase. O propósito dessa reescrita autoral seria "mostrar para os pequenos que as mudanças podem ser positivas, nos levando para novas oportunidades e descobertas”. Entretanto, não há menção ao nome do tradutor que se ocupou de transpor para o português, de recriar para a cultura/língua meta, um texto que, ao que parece, mereceu bastante cuidado por parte de seu autor, tendo em vista o novo público alvo: o público infantil. Segundo o site do grupo, esse texto (bem cuidado por todos os agentes da cadeia editorial que o elaboraram em cada estágio) vendeu no Brasil mais de um milhão de cópias.

\section{(f) Best Seller}

Fundada no ano de 1986, a Best Seller foi incorporada ao Grupo Editorial Record e é a linha editorial do grupo que tem por marca a publicação de obras voltadas para o mundo dos negócios, marketing, liderança, desenvolvimento pessoal, assuntos também abordados em publicações de outros selos da empresa. Como exemplos de publicações da Best Seller, citam-se aqui: Trem para Paris (The 15:17 to Paris), de Spencer Stone, e traduzido por Carlos Szlak, obra classificada como “reportagem” e levada

\footnotetext{
47 Disponível em: <http://www.record.com.br/livro_sinopse.asp?id_livro=28688>. Acesso em 22/09/2019.
} 
às telas por Clint Eastwood em 2018; e a miniedição do clássico de Deepak Chopra, As sete leis espirituais do sucesso, sendo que, neste caso, o nome do tradutor não é informado.

\section{(g) Nova Era}

Criada em 1991, a Nova Era é mais uma editora que passa a integrar o conglomerado editorial Record e a lançar obras na linha da espiritualidade, da religião, da astrologia, em cujo catálogo figuram obras como algumas de autoria de Dalai Lama.

\section{(h) BestBolso}

O texto que descreve o selo Best Bolso deixa claro o objetivo dessa linha editorial: fornecer "títulos clássicos de autores consagrados”, que já integram o catálogo da empresa, "no formato de bolso e a preços mais acessíveis” ${ }^{48}$. Robinson Crusoé, de Daniel Dafoe, Doutor Jivago, de Boris Pasternak, e As sandálias do pescador, de Morris West, são alguns exemplos de clássicos da literatura estrangeira traduzida para o português lançados pelo selo BestBolso. Assim, o selo oferece ao leitor obras consideradas de boa qualidade, mas a um custo sensivelmente mais baixo proporcionado pelo formato de bolso. Além da questão da qualidade literária e do apelo econômico por um produto mais barato, a BestBolso se preocupa também em assumir uma postura política: ao produzir clássicos de autores consagrados a baixo custo, toma "uma iniciativa fundamental para a democratização da leitura”, como descreve o texto do site.

\section{(i) Viva Livros}

Lançado em 2011 como um desdobramento do BestBolso, o selo Viva Livros integra o projeto empreendido pelo grupo para tornar a literatura mais acessível, graças ao formato de bolso (12 x 18). A diferença, como já antecipa o nome do selo, reside nos temas que dão a tônica da maioria de suas publicações: espiritualidade, motivação, saúde, bem-estar, qualidade

\footnotetext{
${ }^{48}$ Disponível em: <http://www.record.com.br/grupoeditorial.editora.asp?id.editora=12>. Acesso em 04/10/2018.
} 
de vida e astrologia. Dentre os autores publicados pelo Viva Livros estão Deepak Chopra e Tony Robbins, classificados pelo selo como "autores que valorizam a vida”.

\section{(j) Bertrand Brasil}

Fundada em 1953, a Bertrand Brasil atuava como importadora e distribuidora de livros franceses e portugueses. Graças ao sucesso de seu primeiro lançamento, o romance Dom Camilo e seu pequeno mundo, de Giovanni Guareschi, a editora lançou outros autores, como Simone de Beauvior, Jean-Paul Sartre, Pierre Grimal e outros. Passou a integrar o Grupo Editorial Record em 1996. No catálogo atual do selo, encontram-se sucessos da literatura contemporânea como Melancia, de Marian Keys, traduzido por Sonia Coutinho, e classificado como “chick lit”49. Já no gênero intitulado “biografia/memória”, figura o clássico Christiane F., 13 anos, drogada, prostituída, sucesso de público que narra a trajetória da adolescente alemã envolvida com a dependência química e o narcotráfico. Diferente de Melancia, obra mais contemporânea, da ficha catalográfica da biografia de Christiane F. disponível no site não consta o nome do tradutor.

\section{(k) Difel}

Assim como a sua antiga matriz, a Bertrand Brasil, a Difel passa a operar como selo do Grupo Editorial Record, sendo responsável pelo lançamento de obras de referência como Séculos de transformações, de Ian Mortimer, historiador contemporâneo inglês, e A psicologia da criança, o clássico de Jean Piaget, canônico escritor na área da psicologia infantil. Mais uma vez, verifica-se a indicação do nome do tradutor (Milton Chaves de Almeida) em uma obra mais atual, que data de $2014^{50}$, enquanto que na representativa obra de Piaget, omite-se o nome do tradutor.

\footnotetext{
${ }^{49}$ Gênero literário moderno destinado ao público feminino, que tem como ícone $O$ diário de Bridget Jones, de Helen Fielding, traduzido por Beatriz Horta e lançado pela Editora Paralela.

${ }^{50}$ Disponível em: https://www.goodreads.com/book/show/20493659-centuries-of-change. Acesso em 27/10/2019.
} 


\section{(l) José Olympio}

Descrita no site do grupo como "um dos pilares da cultura brasileira”, a José Olympio, adquirida pela Record em 2001, setenta anos após a sua fundação, tem no seu currículo o lançamento de clássicos da literatura brasileira como Fogo morto, de José Lins do Rego. Pelo que sugere o texto disponível no site ${ }^{51}$, o selo José Olympio se dedica, se não exclusivamente, principalmente, a reeditar obras lançadas pela empresa durante a sua trajetória editorial. Como exemplos dessa "restauração dinâmica e renovadora” descrita no site, podem-se citar Trópico de Câncer, de Henry Miller, traduzido ${ }^{52}$ por Beatriz Horta, e $O$ deserto do amor, de François Mauriac, traduzido por Raquel de Queiroz.

\section{(m) Rosa dos Tempos}

Fundada em 1990 pela escritora Rose Marie Muraro (1930-2014) e pela atriz Ruth Escobar (1935-2017), teve como objetivo publicar obras de viés feminista. É interessante notar que, das quatorze obras traduzidas publicadas com a chancela deste selo, em apenas cinco dá-se crédito à sua tradutora, como em Mamãe \& Eu \& Mamãe, de autoria da ativista afroamericana Maya Angelou e traduzido por Ana Carolina Mesquita.

\section{(n) Best Business}

Pela ausência de informação quanto a uma existência prévia do Best Business como editora independente, infere-se que se trata de um selo editorial criado dentro do próprio Grupo Editorial Record, a exemplo das linhas editoriais Galera Record e Galerinha Record. Dedicado a publicar obras voltadas ao mundo dos negócios, o texto descritivo do selo Best Business ressalta que os títulos por ele publicados apresentam tom praticamente acadêmico, visto que veiculam informações avalizadas por seus autores, gestores em franca atividade no campo empresarial. Boa parte das traduções publicadas pelo selo disponibilizam o nome de seus

51 “[...] restaura, com frescor e dinamismo, seu patrimônio editorial”. Disponível em: https://www.record.com.br/editoras/jose-olympio/

${ }^{52}$ Até o momento, não se verificou se a tradução de Horta é a única ou se já é uma retradução. 
tradutores, como A fórmula do lançamento, de Jeff Walker, traduzido por Eduardo Rieche e classificada pelo selo como “a bíblia do marketing digital”, e o curioso Aventuras empresariais, de John Brooks e traduzido por Claudia Gerpe Duarte, que narra grandes fracassos de grandes empresas e, segundo consta do site, é o livro de negócios favorito de Bill Gates $^{53}$.

\section{(o) Verus Editora}

Segundo sugerem as informações do site, a Verus é mais uma editora comprada pelo grupo, operação que data do ano de 2000. Além dos gêneros publicados quando de sua atividade como editora autônoma (Rubem Alves e Dalai Lama), já como selo editorial da Record, a Verus vem somando também títulos de ficção. Dois exemplos merecem destaque aqui: o terceiro volume da série ${ }^{54}$ A livraria dos corações solitários, de Annie Darling, traduzido por Cecília Camargo Bartalotti, e Ofélia, de Lisa Klein, traduzido por Rogério Alves, uma "releitura da famosa tragédia de Shakespeare”55, classificado como “ficção”, “romance (história de amor)” e "histórica" 56.

Do ponto de vista teórico, as informações sobre o selo editorial Best Bolso contidas no site reforçam o que André Lefevere (2007) diz a respeito do lançamento de antologias pelas editoras na condição de agentes da patronagem. Considerando se tratar de uma editora brasileira lançando antologias com clássicos da literatura nacional, como os 40 contos escolhidos de Machado de Assis e as 50 crônicas de Rubem Braga, e também da literatura universal, de acordo com o que informou Leitão, contempla-se na edição destas últimas a atividade tradutória:

53 Disponível em: < https://www.record.com.br/produto/aventuras-empresariais/, Acesso em 09/03/2020.

${ }^{54}$ As séries são particularmente significativas no campo editorial.

${ }^{55}$ Disponível em: < https://www.record.com.br/editoras/jose-olympio/>. Acesso em 09/03/2020.

${ }^{56}$ Disponível em: < https://www.record.com.br/editoras/jose-olympio/>. Acesso em 09/03/2020. 
[Editoras] reconhecid[a]s têm [...] papel importante na [...] [conservação do cânone]. Os clássicos a serem ensinados [...] continuam a ser impressos e, portanto, serão conhecidos pela maioria das pessoas expostas à educação na maior parte das sociedades contemporâneas. (LEFEVERE, 2007, p. 41)

No que diz respeito à lucratividade das coletâneas de clássicos - e as compostas por literatura traduzida são particularmente apreciadas pelo público leitor brasileiro - Sapiro (2008, p. 155) diz que

[q]uando um texto é canonizado como clássico e incluído em antologias, programas acadêmicos e livros didáticos, torna-se um produto lucrativo para a editora. Essa conversão de capital simbólico em capital econômico é um processo a longo prazo, ao contrário da procura pelo lucro a curto prazo, que é típico do polo comercial da indústria do livro. É isso que distingue a economia [dos diferentes nichos] da indústria cultural, cujos produtos são protótipos [...] [diferentes] de outras produções industriais. ${ }^{57}$

Ao descrever seu público leitor como “exigente e seletivo”, o selo editorial Best Business circunscreve a sua clientela. Quanto ao produto cultural oferecido pela linha editorial Best Business, frisa-se que não se trata de mais um livro de autoajuda, gênero que, por ser popular, dispensa conteúdo elaborado por experts na área. As obras publicadas pela linha editorial Best Business, como informado no site, “atendem a demanda por informação de gestores e líderes com atividades que requerem pensamento estratégico" 58 . O selo Viva Livros, por seu turno, pelo que se depreende do texto informativo presente no site, oferece um leque mais variado de temas, a maioria de apelo popular, além de também editados no economicamente acessível formato de bolso: "títulos clássicos do acervo do grupo nas linhas de espiritualidade, motivação, saúde, bem-estar, qualidade de vida, astrologia, guias de referência, liderança e negócios”59.

Segundo a descrição constante do site do Grupo Editorial Record, a linha editorial que recebe o mesmo nome do conglomerado, por motivos óbvios, é o “carro-chefe do grupo”. Responsável pelo lançamento de várias tendências

\footnotetext{
${ }^{57}[\mathrm{w}]$ hen a text is canonized as a classic and included in anthologies, academic programmes and literary textbooks, it becomes a profitable product for its Publisher. This conversion of symbolic capital into economic capital is a long-term process, as opposed to the search for short-term profit that is typical of the book industry1s commercial pole. It distinguishes the economy of cultural industries [from the other niches], the products of which are prototypes [...] [different] from [those] of other industrial production.

${ }^{58}$ Disponível em: <http://www.record.com,br/grupoeditorial_editora.asp?id.editora=16>. Acesso em 02/10/2018.

59 Disponível em: <www.record.com.br/grupoeditorial_editora.asp?id_editora=18 $>$. Acesso em $02 / 10 / 2018$
} 
editoriais como informado no site, o selo Record parece funcionar como representante de todo o grupo, sendo que em formato de linha editorial. Nesse cadinho, lançam-se títulos dos mais variados temas e autores, dentre brasileiros e estrangeiros, que assinam clássicos e best-sellers.

Delineando com flagrante clareza tema e público alvo das linhas editoriais em questão, o Grupo Editorial Record parece comprovar empiricamente o que diz Sapiro (2008, p. 163) sobre o que se denomina por “recepção” de um autor ou uma obra, questão contemplada por Bourdieu ao refletir sobre a circulação internacional de ideias. Os nichos temáticos enumerados nos sites dos selos aqui em foco não foram escolhidos aleatoriamente. São assuntos abordados em obras com alto índice de vendas nas chamadas culturas centrais. $\mathrm{O}$ fato de apresentar essa expressiva vendagem significa que o título e/ou o autor teve boa recepção por parte de crítica e de público, pois atendeu a algum tipo de demanda na sua cultura de origem. A partir dessa boa recepção já na cultura exportadora, cria-se a expectativa de que o mesmo cenário mercadológico venha a se repetir na cultura importadora, mas, para que isso aconteça, é necessário que a obra seja traduzida para a língua meta. Desse modo, parece legítimo afirmar que os quatro selos aqui em tela

compartilham um interesse comum no papel e nas propriedades sociais [dos agentes partícipes da importação de textos] ([...] tradutores [e] editores) e no uso literário e social do texto traduzido de acordo com as necessidades específicas [e expectativa] da cultura alvo. [Essa visão mercadológica] possibilita localizar num contexto cultural mais amplo as estratégias e as escolhas [das editoras]. ${ }^{60}$ (SAPIRO, 2008, p. 163)

Com relação ao número de obras traduzidas, tanto as três linhas editoriais então sob responsabilidade de Silvia Leitão quanto a Record, sob a editoria de Renata Pettengill, produzem bastantes traduções. Do total de livros lançados pela Best Bolso e pela Viva Livros, 80\% são traduções, enquanto a Best Business tem 70\% de sua produção composta por títulos traduzidos. Quase 100\% das traduções publicadas pela Viva Livros e pela Best Business têm a cultura anglófona (a

\footnotetext{
${ }^{60}[\ldots]$ share a common interest given a historical in the role and social properties of importers (writers, translators, publishers), and in the literary and social uses of the translated work according to the specific stakes of the target field. This allows publishers' strategies and their choices to be located within a broader cultural context.
} 
norte-americana, mormente) como cultura de origem. A Best Bolso, por outro lado, apresenta um ranking de línguas mais diversificado em razão de ter como produto clássicos da literatura universal, em que se incluem obras de outras culturas além das de língua inglesa - russa, alemã, italiana e espanhola, para citar as mais comuns. Os dados fornecidos por Leitão vêm ao encontro do argumento de Sapiro que, citando Brandshell e West (2005), afirma que

[m]ais da metade dos livros publicados no mundo inteiro são traduções do inglês, língua que, por isso, ocupa uma posição hipercentral (a proporção era algo em torno de 60\% em 1990). [...] Oito línguas ocupam uma posição semiperiférica com uma fatia que corresponde de $1 \%$ a $3 \%$ do mercado internacional (espanhol e italiano, por exemplo). As demais línguas, somadas, têm uma participação de menos de $1 \%$ do mercado internacional, podendo ser, por essa razão, consideradas periféricas. ${ }^{61}$ (BRANDSHELL; WEST, 2005, apud SAPIRO, 2008, p. 158).

Na condição de agente de patronagem, como propõe André Lefevere, o Grupo Editorial Record, aqui representado pelos selos Best Bolso, Best Business, Viva Livros e Record, possui linhas editoriais de perfis distintos que importam títulos que seus editores, após sugestão de agentes literários, sabem que cairão no gosto do público leitor a que se destinam. No caso dos selos Best Bolso, Best Business e Viva Livros, há um assumido compromisso de perpetuar os diferentes cânones: o da literatura universal (Best Bolso), o da literatura voltada para o mundo dos negócios (Best Business) e o voltado para o esoterismo e assuntos afins (Viva Livros). O selo Record, por sua vez, ainda que com um catálogo mais diversificado, tem o compromisso de publicar, num universo mais diminuto, num microcosmo editorial, os gêneros literários que a editora vem lançando desde a sua fundação. Em cada um desses nichos literários, há um cânone formado por obras e autores que adquiriram capital simbólico em suas culturas de origem. Uma vez consagrado no mercado editorial internacional, o título - e, às vezes, seu autor, a reboque - é importado e, ao ser traduzido, passa a compor o cânone da

\footnotetext{
${ }^{61}$ [m]ore than half of the books in the world are translated from English, which thus occupies a hyper-central position (the rate was close to 60\% in the 1990's). [...] Eight languages have a semiperipheral position, with a share that varies from $1 \%$ to $3 \%$ of the international market (Spanish and Italian, for example). The other languages all have a share of less than $1 \%$ of the international market, and may thus be considered peripheral (Branchadell and West 2005).
} 
cultura tradutora, se não por introduzir um novo gênero, certamente por somar-se a algum já existente.

Com base no relato da editora Silvia Leitão, parece legítimo concluir que o cotidiano do campo editorial no que diz respeito à publicação de obras traduzidas comprova a existência de toda uma dinâmica da qual a tradução propriamente dita faz parte, constituindo uma de suas etapas. Assim, a entrevista com Silvia Leitão indica que a tarefa tradutória, diferentemente do que levavam a crer as abordagens de natureza puramente formalista, não são apenas uma operação textual, linguística. Precedendo essa etapa, há todo um processo envolvendo profissionais e tarefas que, embora distintas, complementam-se para atingirem o mesmo objetivo: o de confeccionar um produto cultural, neste caso o livro traduzido. Traduzir não contempla somente o tradutor e não se circunscreve ao ato linguístico, pois, antes que o trabalho textual seja empreendido, ocorre uma dinâmica complexa que envolve “olheiros (scouts) e agentes literários”, por assim dizer, que, atentos ao mercado e às culturas de origem e de destino, ou seja, exportadora e importadora de literatura, recomendam títulos que têm potencial de boa recepção e, por conseguinte, de vendas. Em suma, manifestou-se na entrevista concedida pela ex-editora do Grupo Editorial Record uma série de aspectos teóricos da sociologia da tradução e do traduzir, revelando que a tradução é, de fato, uma prática social. Desse modo, valendo-me dos estudos de teóricos já mencionados aqui, transferirei para uma escala menor, o cenário editorial brasileiro, as peças da engrenagem editorial promotora da publicação de livros traduzidos no Brasil, tendo o Grupo Editorial Record como referência principal. 


\section{A pré-produção: do autor estrangeiro à editora inserida na cultura tradutora}

O segundo capítulo da minha tese está voltado para o processo pelo qual se promove a importação de literatura. Hoje em dia, inúmeros são os canais entre uma editora brasileira e um autor estrangeiro. Além das tradicionais feiras literárias internacionais, há também a internet e as figuras do agente literário e do scout. São esses atores que, funcionando como um "radar literário”, partem em busca de textos interessantes que abordem temas igualmente atraentes que cativarão o leitor, independentemente da cultura a que pertença. Renata Pettengill (2018) informou que, num panorama marcado pelo avanço tecnológico e, sobretudo, com o advento da internet, houve uma pulverização das fontes de informação sobre o lançamento de obras literárias no exterior. Os eventos editoriais, segundo ela, constituem-se no ponto de encontro físico entre casas editoriais (demanda) e agentes literários (oferta), estes funcionando como “pregoeiros” da indústria editorial e oferecendo seus produtos aos representantes das editoras em encontros programados com meia hora de duração cada. A respeito do que vem a ser um agente literário, é curioso o conceito apresentado no site da Editora Albatroz ${ }^{62}$. Segundo o texto lá disponível, à semelhança de um agente de viagens ou de um despachante, o agente literário é descrito como um “facilitador” das negociações entre autores e editoras, pois é ele quem contata as casas editoriais e negocia direitos e termos contratuais. O agente literário é, por conseguinte, o representante de um ator (ou autores) no mercado editorial. Em entrevista concedida a Marcio Renato dos Santos e disponível no site do Jornal da Biblioteca Pública do Paraná ${ }^{63}$, a agente literária Luciana Villas-Boas, que atua no ramo desde 2012, quando se desligou do Grupo Editorial Record, onde ocupava o cargo de diretora editorial, afirmou que o seu critério para aceitar representar um autor, seja brasileiro ou estrangeiro, é a sua obra. Representando quarenta autores

\footnotetext{
${ }^{62}$ Disponível em: $<$ https://editoraalbatroz.com.br> . Acesso em 08/09/2019.

${ }^{63}$ Disponível em: $<$ www.candido.bpp.pr.gov.br/modules/conteudo/conteudo.php:conteudo=1423> . Acesso em 08/09/2019.
} 
à época da entrevista (pelas referências cronológicas nas perguntas e respostas, infere-se que ocorreu de 2015 para cá), Villas-Boas afirma que “a literatura é a forma de expressão artística mais desafiadora”, pois requer de seu avaliador (o agente literário, no caso) um tempo cronológico mais extenso do que um quadro ou uma escultura, por exemplo. Um outro assunto abordado durante a entrevista foi o que viria a ser um "sucesso editorial”. Villas-Boas disse não haver uma fórmula infalível, pois, às vezes, uma tiragem tímida de três mil exemplares de um romance a princípio não muito bem avaliado poderá cair no gosto do público e requerer reimpressões, atingindo uma marca de dez mil exemplares em um ano, o que é surpreendente para um texto no qual pouco se apostou. No entanto, o inverso também pode ocorrer: um título em torno do qual se geraram altas expectativas de vendagem poderá ser uma decepção e terminar com um número considerável de exemplares encalhados.

Os agentes literários podem ser de várias nacionalidades e representam casas editoriais também provenientes de várias partes do mundo, de cujos perfis mercadológicos são profundos conhecedores. Considerando que o agente literário opera como uma espécie de filtro de qualidade para clientes pertencentes às mais variadas culturas, deduz-se que, para desempenhar satisfatoriamente suas funções, seja condição sine qua non que esse profissional conheça profundamente o sistema literário para o qual importará determinada obra, tendo, da mesma forma, uma boa noção do espaço que essa cultura receptora ocupa no sistema literário internacional, como alerta Heilbron (2010, p. 315). Segundo consta do site Produção Editorial $^{64}$, da Escola de Comunicação Social da UFRJ, é o agente literário o grande responsável pelo sucesso de muitos autores, pois, além de atuar como ponte entre escritores e editores, precisa ter a habilidade para lidar com questões de cunho jurídico, como as relacionadas aos direitos do autor. É durante a mediação promovida pelo agente literário que se expõem ao editor as qualidades do produto oferecido. Com isso, o agente literário acaba por conferir valor ao potencial literário do autor, contribuindo, assim, para iniciar a desenvolver, no caso de autores novatos, ou de incrementar, no caso de autores já conhecidos, o

\footnotetext{
${ }^{64}$ Disponível em: < https://peufrj.wordpress.com/2008/12/12/agentes-literarios-e-scouts $>$. Acesso em: 15/11/2018.
} 
capital simbólico - mais uma vez empregando aqui esse conceito bourdieusiano do produtor de literatura e do seu produto literário.

Quanto à aquisição dos direitos autorais para a publicação de obras, incluindo as traduzidas, Pettengill (2018) esclareceu como se dá esse processo especificamente. Tanto no país de origem do autor quanto no mercado internacional, a primeira versão a ser enviada aos agentes literários é o que no campo editorial se denomina "manuscrito", que, de acordo com a editora entrevistada, é o texto bruto, sem edição, digitado em arquivo Word. Os agentes literários, por seu turno, enviam esse manuscrito às casas editorais clientes, cujos editores avaliam se aquela obra se coaduna à linha editorial adotada. Caso mais de uma editora se interesse em publicar a obra, recorrer-se-á ao leilão e, como de praxe nesse tipo de operação, a empresa que fizer a maior oferta é a vencedora. Quando se trata de um autor conhecido, com obras publicadas, no caso de um lançamento, se o agente literário for o mesmo que agenciou pelo menos a última obra, esse novo título será oferecido apenas à editora que já vem publicando esse autor. Nesse caso, a negociação se dá entre o agente literário e a editora só para estabelecer o valor dessa nova obra. Se, porventura, a editora não se interessar em publicar esse lançamento, o agente literário vai oferecer o novo título às casas editoriais concorrentes. Desse ponto em diante, o processo será o mesmo, como descrito anteriormente. As editoras interessadas examinarão o manuscrito para avaliar se há potencial de vendas. Em caso afirmativo, compram-se os direitos e, se houver mais de uma editora interessada, recorre-se ao leilão. Pettengill acrescentou que a venda de direitos autorais para a publicação de uma obra no país de origem do autor e no mercado externo nem sempre é efetuada pelo mesmo agente literário e pela mesma editora. Como exemplificou, um escritor inglês pode ser representado por um agente literário que trabalhe apenas com editoras inglesas, mas a publicação desse autor no mercado internacional, ou seja, para a tradução, pode ficar a cargo de um outro agente literário.

Foi no ano de 2010, em meio à intensa movimentação da LitAg (Literary Agents \& Scouts Centre, espaço em que agentes literários e editores do mundo todo se encontram para conversar e fechar negócios), durante a Feira de Frankfurt, que a agente literária brasileira Lucia Riff concedeu entrevista ao site português 
Ípsilon $^{65}$, voltado para várias subáreas da cultura. Ao longo do encontro que, posteriormente no site, ganhou forma de texto sob o título "Lucia Riff: os desafios de uma agente literária”, Riff comenta alguns aspectos do seu cotidiano profissional. Um ponto importante abordado foi a questão dos leilões. Conforme alegou, nos leilões de direitos autorais, nem sempre ganha a maior oferta em dinheiro. Além do fator pecuniário propriamente dito, há outros quesitos que pesam, quesitos estes referentes ao tratamento que as editoras concorrentes propõem dar ao autor e sua obra, objeto da negociação ali em curso. Note-se que a informação fornecida por Riff relativa ao vencedor de um leilão difere um pouco do que relatou Pettengill, o que indica que as práticas editoriais, assim como as visões do processo, variam de editora para editora. Além do fator financeiro, a questão do trato editorial à obra parece ser decisiva. Pelo que relatou Riff, não basta a editora interessada dar o maior lance. É fundamental que as editoras concorrentes se comprometam a executar todo o processo editorial com o máximo de esmero possível. Como exemplo, Riff cita o caso de Rubem Fonseca que, à época, estava saindo da editora Companhia das Letras, e a Agência Riff, na condição de representante do escritor brasileiro, recorreu ao leilão para escolher a sua nova casa editorial. Como informou Riff, negociar a publicação de um escritor do status de um Rubem Fonseca, por exemplo, não é o mesmo que negociar a publicação de um best-seller, ainda que de autoria de um Dan Brown. Enquanto este poderá ficar por pouco tempo na memória do leitor, aquele tem lugar de importância quase que cativa dentro de qualquer sistema literário, seja de língua portuguesa ou de língua estrangeira, este para tradução. O relato de Riff, portanto, sinaliza que serão o capital simbólico do autor e também a posição do gênero literário por ele produzido que determinarão a postura das casas editoriais participantes dos leilões. De acordo com o autor e/ou gênero literário em questão, poderá preponderar tão-somente o fator comercial (potencial de vendas) ou, no caso de um autor consagrado por sua sofisticação textual e complexidade na abordagem de temas, além do alto valor do lance no leilão, deverá haver também um certo requinte por parte da casa editorial na hora de tratar esse autor, essa obra. Assim, esse refinamento no trato estará presente em todo o processo aqui

65 Disponível em: < https://www.publico.pt/2010/11/04/culturaipsilon/noticia/lucia-riff-osdesafios-de-uma-agente-literaria-268754. Acesso em junho/2019. 
examinado: no caso de uma obra para a tradução, por exemplo, o tradutor e o revisor serão escolhidos a dedo, podendo essa seleção mais criteriosa afetar, inclusive, o valor da lauda para a tradução e para as revisões (copidesque e revisões subsequentes). Em alguns casos, a capa e o título a revestir e a nominar a obra, respectivamente, deverão ter o aval de uma série de agentes, incluindo o próprio autor. Isso sem falar nas estratégias de divulgação que deverão ser as mais eficientes possíveis para garantir que esse autor tão especial tenha a visibilidade que merece.

O scout, por seu turno, vem se revelando figura imprescindível no mercado editorial internacional, visto que é ele que está mais em contato com jornalistas estrangeiros e também com agentes literários, atuando como um “olheiro" da editora que o contrata. Na condição de estrangeiro, mas conhecedor do perfil de seu contratante, é capaz de detectar o que seria vendável no mercado alvo. Surpresa com a existência dessa “nova” modalidade de agente literário, resolvi pesquisar mais sobre esse profissional e acabei por descobrir, no mesmo site Produção Editorial (ECA/UFRJ), que essa atividade já existe nos Estados Unidos e na Europa desde as décadas de 1950 e 1960. Com a intensificação do mercado editorial mundo afora, os serviços do scout vêm se fazendo também cada vez mais necessários para as casas editoriais. Em 11 de outubro de 2013, o site da revista Valor Econômico ${ }^{66}$ disponibilizou matéria com o intuito de dar visibilidade a esse desconhecido que, hoje, desempenha papel particularmente relevante no campo editorial. Intitulado "Os caçadores de talentos” e escrito por Camila Moraes, o artigo, a exemplo do compartilhado pelo site Vai Lendo, este tendo por objeto a figura do livreiro, também consiste numa colagem de entrevistas com scouts que atuam como “olheiros literários” para editoras brasileiras. Dada a grande quantidade de obras em busca de publicação, não há tempo hábil para que os editores leiam todas na íntegra. Assim, cabe ao scout resumi-las para que os editores tenham uma ideia geral do enredo. Ao ler um romance recém-lançado no mercado internacional e ao selecionar personagens e eventos que possam integrar a sinopse elaborada de forma a atrair o interesse do editor estrangeiro, o scout acaba por se tornar o primeiro agente da cadeia

\footnotetext{
${ }^{66}$ Disponível em: < http://www.cristinadestefano.com/documents/2630181/8b06002b-d0d6-4d9f849c-2d0bf4e103ba>. Acesso em: 15/11/2018.
} 
editorial a reescrever aquela obra postulante à exportação para o mercado estrangeiro e, subsequentemente, a ser traduzida para o vernáculo local. Como argumenta André Lefevere (2007, p. 11), toda reescrita está sujeita a coerções de ordem ideológica e poetológica na cultura de recepção. Desse modo, se, por um lado, pode estar a serviço de quem detém o poder (aspecto negativo, como deixa subentendido), por outro, é agente fundamental para o desenvolvimento de uma literatura, pois pode "introduzir novos conceitos, novos gêneros, novos artifícios e a história da tradução é também de inovação literária, do poder formador de uma cultura sobre a outra” (LEFEVERE, 2007, p. 11-12). Dentre os exemplos de reescritores citados por Lefevere (2007, p. 15), parece haver maior semelhança entre o contemporâneo scout e o erudito renascentista, pois ambos, dadas as devidas diferenças, se ocupam de selecionar obras, algumas em sua integralidade e outras apenas em trechos, a fim de veicular um resultado final que atenda a uma demanda cultural e/ou comercial.

Corroborando os relatos de Renata Pettengill e Silvia Leitão, a matéria da Valor Econômico também marca como traço distintivo entre scout e agente literário o fato de o primeiro ser estrangeiro e prestar serviço para apenas uma editora, enquanto que o segundo é, via de regra, brasileiro e representa mais de uma editora, dentre brasileiras e estrangeiras, além de agenciarem autores individualmente. Conforme definiu Maria Campbell, norte-americana de ascendência italiana e uma das scouts mais proeminentes do mundo, a atividade de scouting é “a arte de fazer boas pontes, dando informação valiosa e responsável” (Valor Econômico, 2013, p. 1). Ao atribuir à ideia de "informação" as qualidades “valiosa e responsável”, Campbell revela o quanto o scout precisa ser criterioso e ponderado ao sugerir uma obra ao seu contratante. Segundo ela, "a qualidade do trabalho do scout é proporcional à do seu cliente" (Valor Econômico, 2013, p. 1), ou seja, se o editor só tem por meta publicar best-seller visando única e exclusivamente ao lucro, "não entende bem o trabalho” (Valor Econômico, 2013, p. 1). A italiana Cristina De Stefano, por sua vez, tem o seu “radar literário” voltado para a Itália e a França a serviço da Editora Objetiva. Segundo informou, o Brasil é "sempre ávido por publicar títulos bem avaliados antes mesmo [do lançamento em] seus países de origem” (DE STEFANO, 2013). Ainda segundo De Stefano, desde 2011, o mercado editorial brasileiro vem 
praticando o que ela denominou preemptive offer em que o editor, para obter os direitos de publicação da obra, faz uma oferta prévia e direta ao detentor do copyright do título desejado com o intuito de publicar uma grande quantidade de exemplares. Essa estratégia é vantajosa para ambas as partes, pois, se de um lado, assegura ao detentor dos direitos de publicação da obra uma venda antecipada de uma tiragem numericamente significativa, do outro, afiança à casa editorial a contratação daquela obra sem ter que enfrentar em um leilão a concorrência de outras casas editoriais.

Examinando os perfis do agente literário e do scout que se delinearam ao longo da leitura dos textos aqui citados, parece legítimo afirmar que é na fase do processo ora em análise que se vê nitidamente a dupla face da literatura, não constituindo a traduzida nenhuma exceção: por um lado, como obra artística, construída segundo critérios estéticos, e, por outro, como produto comercial, avaliado conforme parâmetros mercantis. É essa dualidade, essa dupla dimensão da obra literária (a traduzida, inclusa) que parece dar a tônica ao trabalho do agente literário e do scout. Pelo que se pôde depreender da leitura do material aqui utilizado como referência, não há critérios objetivos que possam nortear esses profissionais com relação à convergência ou à exclusão desses dois aspectos numa só obra.

No tocante às feiras literárias, Pedro Herz, dono da Livraria Cultura, oferece um rico depoimento em sua coletânea de memórias O livreiro. Segundo Herz (2017, p. 97), as feiras literárias, sobretudo a de Frankfurt pela sua extrema relevância, funcionam como uma zona franca, onde profissionais que circulam e atuam no campo editorial podem trocar ideias e realizar negócios ${ }^{67}$. Para Herz, a facilidade proporcionada pela era digital acelera e otimiza substancialmente as negociações no mercado editorial. Pela internet, realiza-se todo tipo de negócio, inclusive a compra de direitos autorais. No entanto, conforme relata em suas memórias, nas últimas edições da Feira de Frankfurt a que compareceu, Herz observou que o espaço físico destinado aos agentes literários tem mantido a movimentação de sempre, fazendo-o concluir que nem a rapidez e a comodidade promovida pela internet pode substituir o contato físico entre os agentes do campo

\footnotetext{
${ }^{67}$ Provavelmente, Herz se refere aqui a LitAg (Literary Agents \& Scouts Centre), mencionada no artigo sobre Lucia Riff.
} 
editorial. Quanto à aquisição de direitos autorais de uma obra, por exemplo, Herz (2017, p. 102) faz uma revelação importante: a necessidade de se reinventar imposta aos agentes literários pela constante proliferação de novas modalidades de mídia. Com o desenvolvimento de várias tecnologias, as obras literárias, que antes se restringiam ao livro impresso e a eventuais adaptações para o cinema, o teatro e a televisão, hoje também são veiculadas por outros meios como o livro eletrônico e o audiobook. Assim, alega Herz, os agentes literários da era digital, “[n]egociam direitos sobre determinado conteúdo, que pode se expressar em diferentes suportes” (p. 102). Como se pode observar, os comentários de Herz contemplam a inclusão das novas modalidades de mídia na negociação dos direitos autorais e complementam o que disseram Pettengill e Riff a respeito do tema.

Até este ponto, observaram-se os atores integrantes do que se denominaria aqui de fase “pré-editorial”, por assim dizer. Isto porque agentes literários e scouts são partícipes que, embora intimamente ligados ao campo editorial, atuam preparando o terreno para que o trabalho editorial propriamente dito possa se desenvolver plenamente. Desse modo, daqui em diante, o foco desta pesquisa será voltado para o primeiro elemento que se poderia classificar como de fato endógeno ao trabalho editorial: o editor. Em dezembro de 2014, a editora Laura Bacellar concedeu caudalosa entrevista (dividida em duas partes) à jornalista e historiadora Dida Bessana ${ }^{68}$, em que não apenas fala sobre a profissão de editor, mas também expõe a sua opinião a respeito do cenário editorial que se apresentava à época da entrevista. Com uma carreira construída ao longo de mais de trinta e cinco anos, com passagem por editoras brasileiras da importância da Paz e Terra, hoje um selo Record, da Brasiliense e da Scipione, para a qual adaptou clássicos como Robinson Crusoe, Drácula e Rei Arthur, Bacellar começa a entrevista procurando conceituar o papel do editor no campo editorial. Segundo ela, o editor precisa ser dotado de uma espécie de "feeling coletivo", para ser capaz de detectar o interesse dos diversos nichos do leitorado. À semelhança do que diz um dos versos da canção Nos bailes da vida, de Fernando Brant e Milton Nascimento, segundo o qual "todo o artista tem de ir aonde o povo está”, o editor

\footnotetext{
${ }^{68}$ Disponível em http://didabessana.wixsite.com/historiasdolivro. Acesso em 08/09/2019.
} 
também precisa, como argumenta Bacellar, oferecer ao leitor aquilo que ele quer ler. Dotado desse “radar temático”, o editor poderá reduzir sensivelmente o risco de um fracasso de vendas, considerando o alto investimento que a publicação e a divulgação de uma obra requerem. Muitas vezes, o autor (brasileiro ou estrangeiro) não tem um grande potencial literário, do ponto de vista textual, mas aborda temas que são de interesse desse ou daquele público. É o que Bacellar chama de "obra pertinente”, ou seja, uma obra cujo texto não apresenta alta qualidade poetológica, segundo os padrões da época, mas que pode estar tratando ali de temas que falam ao coração de algum segmento do público leitor. Bacellar frisa que o editor, na hora de escolher uma obra para publicar, seja nacional ou estrangeira, precisa olhar o outro (o leitor), para ter chances de emplacar um sucesso editorial. Segundo relatou, atuam no mercado editorial brasileiro muitos agentes que, além de carecerem de formação na área, trazem internalizado, em algum grau, um ranço elitista que faz com que rejeitem obras promissoras em prol de outras que apresentam um texto sofisticado, mas que não atingirão um público numericamente satisfatório do ponto de vista comercial. Ao optar por uma obra de estilo erudito, o editor usa seus próprios critérios seletivos, sem levar em consideração que tipo de texto quer ler o leitor. No afã de tentar oferecer (ou impor) ao leitor comum obras que, de acordo com seus próprios parâmetros, merecem ser lidas, o editor acaba por causar à editora um prejuízo incalculável. Um exemplo clássico dessa falta de "feeling coletivo" ou de "faro comercial” é a lucrativíssima franquia Harry Potter que, só no Brasil, conforme relatou Bacellar, foi recusada por nada menos do que onze editoras. A agente literária representante da autora J.K. Rowling precisou se desdobrar em argumentos para convencer os editores da Rocco de que a saga do bruxinho, sem dúvida alguma, cativaria o público infantojuvenil. Como informa Bacellar, o lançamento de Harry Potter e a pedra filosofal foi um dos primeiros casos de instantâneo sucesso mundial ocorrido de forma massiva.

É esse “olhar mais treinado”, como denomina Bacellar (2014), que, de um modo geral, falta ao editor brasileiro e sobra no editor norte-americano. Nos Estados Unidos, conta ela, o editor consegue captar antecipadamente, numa obra, o que vai funcionar e o que vai servir de empecilho para que a trama (no caso de uma peça de ficção) se desenvolva com fluidez necessária para ensejar o turbilhão 
narrativo que vai arrebatar o leitor do início ao fim da leitura. Bacellar alega que é justamente essa "visão decantadora” de que carece o editor brasileiro que, segundo sua observação, faz com que ele insista em optar por obras que, de acordo com seus critérios pessoais, podem ser classificadas como alta literatura. O que o editor brasileiro precisa ter em mente, sustenta Bacellar, é que o mercado editorial sobrevive de vender livros e a política de tentar "elevar” intelectualmente o leitor vai na contramão da demanda da grande maioria do leitorado. Entre publicar obras com texto refinado, mas que encalham nas livrarias, e obras nem tão bem escritas, mas que abordam temas de interesse de vários nichos do leitorado, Bacellar recomenda que se opte por estas últimas Ao fazer essa “decantação textual”, como alega ela, o editor aumenta a vida útil do livro, ou seja, faz com que aquela obra seja lida por mais leitores, já que o seu texto agrega um número considerável de temas que interessam a uma gama maior de leitores. Dividindo o público em dois grupos, o elitista e o popular, e mantendo sempre uma perspectiva comercial, Bacellar detecta que há uma ausência de biunivocidade entre eles. Se, por um lado, o leitor popular não quer e não lê Dostoiévski, por exemplo, o leitor elitista, por outro, lê Dan Brown. Essa ausência de reciprocidade parece nos remeter a dois conceitos desenvolvidos no âmbito da Sociologia das Práticas Sociais: “onivorismo cultural” e “univorismo cultural”. O primeiro se refere ao leitor com nível de escolaridade mais elevado, que consome quaisquer tipos de literatura, da mais elaborada esteticamente à chamada "literatura trade", comercial, de fácil consumo, feita para o entretenimento. O segundo é o praticado pelo leitor de nível de escolaridade mais baixo, que possui um círculo mais limitado de gêneros literários. Com base nessa "não biunivocidade", Bacellar afirma que as editoras precisam investir mais na literatura de maior apelo popular, pois é mais abrangente no que tange ao fator comercial, visto que atinge os dois grupos. Convém alertar aqui que, muito embora se deva considerar a opinião de Bacellar como a de uma profissional respeitada no campo editorial, não se pode tomá-la como geral, visto que, dos editores aqui citados, ela foi a única a comentar sobre a opção entre publicar alta literatura ou literatura popular.

A saga de Harry Potter, pelo retumbante sucesso de público, parece merecer que se lhe dedique um pouco mais de atenção neste capítulo voltado para 
a fase de pré-produção de uma obra literária. Afinal, a série criada por J.K. Rowling é um bom exemplo a ser examinado, uma vez que, tendo sido traduzida para nada menos do que setenta e cinco línguas, curiosamente incluindo o latim, segundo o site Wikipédia ${ }^{69}$, pode ser considerada um integrante significativo do campo da literatura traduzida em todo o mundo. Sobre Harry Potter, o ponto a se considerar aqui é o que contém a obra de Rowling para ter contrariado as expectativas (equivocadas, como já visto anteriormente) do mercado editorial e se tornado num dos maiores best-sellers de todos os tempos? Pelo menos até o presente momento, a obra da então estreante J. K. Rowling parece ser um bom exemplo do que a editora Laura Bacellar denominou “erro editorial”. Movida por essa questão, a jornalista Renata Beltrão publicou um artigo (2017) com o autoexplicativo título "Harry Potter contra o preconceito literário"70. Em seu texto, Beltrão tenta fazer uma espécie de redenção da autora inglesa e de sua obra que, lançada vinte anos antes da publicação de seu artigo, foi classificada pela crítica como "porcaria literária”. Nele, a jornalista identifica sete razões que levaram Harry Potter a ocupar, por um longo período de tempo, o topo dos livros mais vendidos (e lidos). Dentre os sete pontos elencados por Beltrão, destaco a universalidade e a atemporalidade da obra de Rowling. Abordando temas como baixa autoestima, necessidade de aceitação, conflitos familiares e bullying, que permeiam a adolescência, fase em que se encontram tanto os personagens quantos os leitores, a autora promove uma perfeita identificação entre obra e público. A atemporalidade identificada por Ventura em Harry Potter reside no fato de que a autora trouxe para um espaço ficcional em que coexistem medievalidade e contemporaneidade, figuras como bruxos, fadas, duendes e dragões, que são sempre ingredientes para uma bem-sucedida narrativa para crianças e adolescentes. Esse fator em particular foi apontado pelo escritor Umberto Eco que, em seu livro Pape Satán Aleppe, contrariando a opinião da crítica, vê qualidades na narrativa de Rowling, chegando a compará-la a clássicos como

69

$<$ https://pt.wikipedia.org/wiki/Tradu\%C3\%A7\%C3\%B5es_de_Harry_Potter\#Lista_de_tradu\%C3 \%A7\%C3\%B5es_por_lingua >. Acesso em 29/12/2019.

70 Disponível em: https://lombadaquadrada.com/2017/07/01/harry-potter-contra-o-preconceitoliterario/ Acesso em 27/12/2019. 
Oliver Twist, de Charles Dickens, e Os meninos da rua Paulo, de Ferenc Molnár, como aponta Rodrigo Casarin ${ }^{71}$.

Em 30/11/2017, a revista Tradterm, da USP, publicou uma entrevista concedida por dois editores da Companhia das Letrinhas, Antônio Augusto Castro do Nascimento e Gabriela Ubig Tonelli, em que falavam sobre o mercado de traduções. Sobre o percentual de obras traduzidas para os públicos infantil e juvenil, os editores informaram que cerca de metade das obras publicadas pelos selos voltados para esses dois nichos, o Seguinte (juvenil) e o Companhia das Letrinhas (infantil), é de obras traduzidas. Com relação a uma possível intervenção do autor do original ou da editora estrangeira no texto traduzido, Nascimento e Tonelli afirmaram que, quando da aquisição dos direitos de publicação de uma obra estrangeira no Brasil, às vezes, por força de contrato, poderá haver a obrigatoriedade de a identidade do tradutor e/ou a versão traduzida serem submetidas ao escrutínio do autor ou de algum representante seu. Embora possível, conforme relataram, essa exigência raramente ocorre e, assim, tanto a escolha do tradutor quanto a versão final do texto traduzido serem prerrogativas da equipe editorial. Sobre as mudanças que sofre o texto traduzido depois de concluído o trabalho do tradutor, o processo descrito pelos editores entrevistados é bem semelhante ao relatado por Pettengill e Leitão. O texto traduzido passa inescapavelmente por, pelo menos, duas revisões, normalmente feitas por freelancers, a exemplo do tradutor. A decisão final de quais mudanças permanecem ou quais são revertidas é do editor, ou seja, o texto que chega às mãos do consumidor final é a versão aprovada pelo editor. Indagados sobre os maiores cuidados em relação a um texto traduzido para o público infantil, Nascimento e Tonelli responderam que o texto "deve conversar [...] com a criança brasileira”. Segundo eles, se, por um lado, certos aspectos do texto, como o tom, por exemplo, precisam ser mantidos, outros, porém, precisam ser adaptados. Um livro que fale sobre sorvete, por exemplo, precisa apresentar sabores conhecidos do leitor infantil brasileiro. Num caso como esse, há uma negociação entre editor

\footnotetext{
71 Disponível em https://paginacinco.blogosfera.uol.com.br/2017/06/28/o-homem-que-e-rei-deum-reino-onde-nao-vive-ninguem-nem-ele-mesmo/\#: :text=P\%C3\%A1gina\%20Cinco,O\%20homem\%20que\%20\%C3\%A9\%20rei\%20de\%20um\%20reino,vive\%20ningu\%C3\%A9m\% 20\%E2\%80\%93\%20nem\%20ele\%20mesmo\&text=O\%20rei\%20Javier\%20Mar\%C3\%ADas. Acesso em 27/12/2019
} 
e tradutor e entre editor e detentor do copyright para que aquele contexto, estranho à criança brasileira, seja recriado da melhor forma possível, para que seja bem recebido por esse leitor. No que tange à questão de domesticar ou estrangeirizar o texto, os editores afirmaram que a regra é não descaracterizar a narrativa, abrasileirando apenas o que for incompreensível, sobretudo se for algum constituinte fundamental para o entendimento para a trama. Para eles, o que não se pode perder de vista é a completa interação entre o leitor e a trama, o que passa invariavelmente pela completa compreensão do texto em si.

Após esta incursão na fase que antecede a confecção do texto traduzido, ou seja, depois de procurar compreender melhor as relações comerciais envolvidas na importação de uma obra estrangeira e também o que subjaz aos critérios de escolha dessa obra para tradução, no capítulo seguinte, procurar-se-á conhecer um pouco mais sobre esse agente a quem caberá a transformação linguística que viabilizará o consumo do bem cultural aqui em foco: a obra traduzida. 


\section{A produção (fase 1): o papel do tradutor na cadeia editorial}

Ao longo das últimas quatro décadas, quando estudiosos da área da linguagem se dedicaram a analisar a tradução, muito se falou da atividade em si. Seja assumindo um viés prescritivo e essencialista, seja adotando perspectivas funcionalistas, descritivistas, que surgiram a partir dos anos 1970, o foco das abordagens tem sido sempre a atividade tradutória, mas, muito raramente, o seu executor. Ratificando essa ideia, o teórico australiano Anthony Pym (2006, p. 2) argumenta que os Estudos da Tradução ainda carecem de "uma ortodoxia que possa ser chamada de sociologia dos tradutores"72. Chesterman (2014), identificando nos Estudos da Tradução uma tendência recente de enfocar explicitamente o tradutor em vez de apenas as traduções propriamente ditas, propõe a denominação Estudos do Tradutor para esse novo campo de interesse. Argumenta Chesterman que indícios dessa tendência são observados principalmente na sociologia da tradução, mas também são detectáveis na história da tradução e em pesquisas sobre os processos decisórios do tradutor. Este capítulo será dedicado a esboçar um perfil, ou talvez, perfis do profissional que viabiliza o acesso à leitura de textos estrangeiros escritos numa língua não dominada pelo leitor a que aquele texto importado e traduzido se destina. A fim de se revelar quem é esse profissional, faz-se necessário levantar algumas questões que exprimem crenças e expectativas gerais a seu respeito, tais como:

- Basta ser bilíngue para credenciar alguém à função de tradutor?

- Para desempenhar as suas funções, o tradutor precisa ter que habilidades e que formação acadêmica?

- A profissão de tradutor é regulamentada por algum tipo de legislação? Se o for, de que tipo de legislação se trata e que direitos e deveres essa legislação institui para tradutores e contratantes?

- Quais as características que o mercado editorial mais valoriza num tradutor?

\footnotetext{
${ }^{72}[\ldots]$ any orthodoxy that might be called a sociology of translators.
} 
As respostas a essas perguntas não só ajudaram a formar um perfil (ou perfis) de tradutor, mas também ajudaram a entender a função que exerce na cadeia de que participa, lembrando que a cadeia aqui em foco se processa no campo editorial, além de revelar a questão do amparo legal de que carece a profissão. Antes de passar ao perfil do tradutor propriamente dito, faz-se necessário abordar o aspecto jurídico que reveste uma possível regulamentação da profissão de tradutor.

Reconhecida como profissão liberal por intermédio da Portaria 3264/1988 ${ }^{73}$, do Ministério do Trabalho, a profissão de tradutor ainda carece de uma regulamentação formal que discipline direitos e deveres desse profissional tão requisitado num mundo globalizado como o de hoje. Em artigo publicado em abril de $2015^{74}$, Raphael Silva Ribeiro ${ }^{75}$ fala da imprescindibilidade de se regulamentar a profissão de tradutor, conceituada por Ribeiro como "profissional da linguagem”. Estabelece, então, o autor uma relação de causa e efeito entre três fatores: a baixa oferta, no Brasil, de cursos universitários de formação de tradutores, muito embora essa afirmação deva ser vista com reservas, diante do número crescente de cursos universitários de formação de tradutores abertos recentemente ou com projeto em andamento, como na Universidade Federal Fluminense; a falta de regulamentação da profissão; e a desvalorização do tradutor. Ribeiro alega, desse modo, que em não havendo tradutores com a devida chancela acadêmica para atuar como tais, é impossível estabelecer qualquer texto regulador da atividade, o que leva a uma consequente desvalorização. Vale ressaltar aqui, porém, que essa é apenas uma das causas da desvalorização da tradução e do tradutor, como vem sendo amplamente discutido pela comunidade de estudiosos da tradução. Juntamente com a não exigência de uma formação acadêmica para que se possa traduzir profissionalmente, outros fatores vêm, ao longo de décadas, contribuindo para que tanto a profissão quanto a atividade deixem de receber o devido reconhecimento, dentre os quais podemos citar: a

\footnotetext{
${ }^{73}$ Portaria No 3.264, de 27 de setembro de 1988, publicada no Diário Oficial em 3 de outubro de 1988. Disponível em < https://www.sintra.org.br/o-sintra/>. Acesso em 17/07/2020

${ }^{74}$ Disponível em: http://jus.com.br/amp/artigos/37740/1 . Acesso em 04/12/2019.

${ }^{75}$ Não se encontraram informações biográficas precisas e confiáveis acerca do autor do artigo, apenas sendo possível inferir, pelo site em que se publicou o texto, que deva ser ou ter sido ligado à área do direito.
} 
equivocada visão da tradução como mera cópia, o que a mantém, aos olhos do leigo, como um produto eternamente inferior ao texto de origem; a falta de menção ao tradutor nas resenhas literárias; e a ausência quase que total do tradutor nas atividades programas em eventos como a Bienal do Livro e a FLIP, ambos realizados no Brasil. Segundo entende Ribeiro, a tradução é uma atividade específica que exige de seu executor conhecimentos na área de Letras, mais especificamente na subárea da tradução. Essa lacuna acadêmica, por assim dizer, impede que se forme um fluxo contínuo de profissionais da tradução que atenda a uma crescente demanda de mercado. Assinale-se que, na ideia de Ribeiro, contempla-se não apenas o tradutor técnico, mas também o literário contratado pelas casas editoriais. O que parece bastante interessante e pertinente à presente pesquisa é que o autor desenvolve em seu artigo uma visão da tradução como uma modalidade de prestação de serviço, ideia que inescapavelmente envolve duas partes: a que contrata e a que é contratada. Desse modo, Ribeiro chama a atenção para o risco que corre o contratante que inadvertidamente contrata um tradutor sem formação na área de tradução, independentemente do gênero textual em questão, seja o manual de uma caldeira ou uma obra literária adulterada por uma tradução feita amadoristicamente. No caso da caldeira, há o risco de morte ocasionado por uma explosão; no caso da obra literária, o risco de ter todo o cronograma de lançamento afetado, o que acarreta prejuízo à editora. Alega Ribeiro, então, que a regulamentação da profissão de tradutor asseguraria direitos e deveres para ambas as partes, dando ao tradutor a valorização profissional (incluído aí o aspecto pecuniário), de um lado, e, de outro, atribuindo-lhe a responsabilidade formal e legal pelo serviço que presta. Conforme propõe Ribeiro, a regulamentação da profissão de tradutor contemplaria, dentre outros, os seguintes pontos: ética na prestação de serviço; descrição e definição de tradução (atividade) e de tradutor (profissional), além do conceito de autoria. No que tange a esta questão, a relativa à noção de autoria, Ribeiro também cita a lei que disciplina os direitos autorais, a Lei ${ }^{\circ}$ 9. 610, de 19 de fevereiro de $1998^{76}$, que “altera, atualiza e consolida a legislação sobre direitos autorais”. O inciso XI do artigo $7^{\circ}$ da referida legislação dispõe que:

\footnotetext{
${ }^{76}$ Disponível em: http://www.planalto.gov.br/ccivil_03/leis/19610.htm. Acesso em 08/12/2019.
} 
Art. $7^{\circ}$ São obras intelectuais protegidas as criações do espírito, expressas por qualquer meio ou fixadas em qualquer suporte, tangível ou intangível, conhecido ou que se invente no futuro, tais como:

XI - as adaptações, traduções e outras transformações de obras originais, apresentadas como criação intelectual nova;

Em referência ao crédito ao nome do tradutor em cada exemplar de uma obra traduzida, diz o artigo 53 do mesmo dispositivo legal:

Art. 53. Mediante contrato de edição, o editor, obrigando-se a reproduzir e a divulgar a obra literária, artística ou científica, fica autorizado, em caráter de exclusividade, a publicá-la e a explorá-la pelo prazo e nas condições pactuadas com o autor.

Parágrafo único. Em cada exemplar da obra o editor mencionará:

II - no caso de tradução, o título original e o nome do tradutor;

A despeito da louvável intenção de que se reveste a proposta de Ribeiro, há que se alertar aqui que a regulamentação da profissão de tradutor envolve uma série de questões que há anos vêm obstruindo a iniciativa do SINTRA (Sindicato Nacional dos Tradutores) nesse sentido. No caso da tradução de poesia, por exemplo, como cobrar, por força de lei, formação acadêmica de um poeta brasileiro consagrado que tenha traduzido inúmeros poemas e, muitas vezes, até obras completas de poetas estrangeiros igualmente consagrados em suas culturas de origem? Se, no texto legal, houver uma ressalva contemplando esse caso, que período cronológico referente ao fator “experiência” se deve estabelecer para dispensar tal tradutor dessa exigência legal? Um outro caso a se considerar é o campo da tradução técnica, em que as traduções não são assinadas pelo tradutor, ou seja, não há uma identificação formal de quem executou a tradução de um contrato ou de um manual, por exemplo. Assim, como comprovar a experiência desse profissional? Se for adotado o critério de apresentação de documentos tais como recibos e notas fiscais, isso não poderia ensejar o surgimento de documentos forjados com o intuito de se "comprovar" uma experiência profissional até inexistente? Uma possível regulamentação da profissão de tradutor, se feita de afogadilho, poderá também ocasionar o aparecimento de uma série de cursinhos, cuja qualidade dificilmente poderá ser comprovada, apenas 
com o intuito de auferir lucro mediante a falsa promessa de proporcionar uma qualificação profissional futuramente lucrativa. Esses são apenas alguns dos muitos aspectos que devem ser levados em conta e discutidos à exaustão antes de se tentar formalizar uma proposta legislativa que vise à regulamentação da profissão do tradutor.

Feito esse preâmbulo de cunho legal, volta-se o foco ao agente da etapa da confecção do texto traduzido. É sempre importante frisar aqui que a modalidade de tradução que é objeto de análise da presente pesquisa é a de natureza literária, que, como quaisquer outras categorias de reescrita tradutória, apresenta suas especificidades, características estas que refletem as habilidades requeridas do seu executor, o tradutor literário. Ivone Benedetti e Adail Sobral (2003) reuniram numa coletânea entrevistas com tradutores renomados em que se abordam temas relevantes concernentes ao perfil do tradutor, como as habilidades que dele se requerem, formação acadêmica e experiência profissional, para citar alguns, e também temas relativos ao exercício da profissão como o que o entrevistado entende por tradução inadequada, sua opinião sobre o Acordo Ortográfico vigente e a questão remuneratória. O tradutor e professor Paulo Henriques Britto, um dos entrevistados, conceitua a tradução literária (tanto a de poesia quanto a de prosa) como uma "zona de fronteira" (BRITTO, 2003, p. 90). A interseção a que se refere Britto é formada pelo aspecto técnico da tradução lato sensu, que é o manuseio gramatical necessário para se transformar o texto A (texto estrangeiro = texto produzido na língua de partida) no texto B (texto traduzido = produzido na língua de chegada) e pelo aspecto artístico ensejado pela tradução de literatura, inegavelmente uma arte e que se pauta, de modo geral, na estética da língua/cultura alvo. Por transitar ao longo desse cruzamento de searas, Britto diz que

o tradutor literário pertence ao mesmo tempo ao mundo da tradução propriamente dito - o mundo ao qual pertencem também os tradutores juramentados, os intérpretes de conferência as pessoas que fazem localização de software - e também ao mundo da literatura, à esfera em que transitam os romancistas, os poetas, os ensaístas. (BRITTO, 2003, p. 90)

No que tange a esse "hibridismo" relativo às habilidades requeridas do tradutor literário, o tradutor Mario Laranjeira, na entrevista que também integra a 
coletânea organizada por Benedetti e Sobral (2003), fala sobre a habilidade que o tradutor literário precisa ter de “produzir, em sua língua/cultura, um texto que seja uma peça literária” (BENEDETTI; SOBRAL, 2003, P. 120). Essa peça literária, como esclarece Laranjeira, precisa aliar conteúdo e forma, mensagem e texto, sem se ater somente ao que se diz, mas, sobretudo, voltando a atenção para a forma como esse conteúdo está sendo expressado linguística e poetologicamente. Esse texto literário reescrito por intermédio da tradução, como argumenta Laranjeira, precisa ser “capaz de despertar no leitor [da versão traduzida] o prazer estético, le plaisir du text, no dizer de Roland Barthes”. (BENEDETTI; SOBRAL, 2003, p. 121). O tradutor adverte, porém, que, como a reescrita tradutória precisa corresponder ao texto original ("homóloga”, no dizer dele), o tradutor literário deverá ser capaz de identificar no texto fonte todo o trabalho lexical e semântico engendrado pelo autor. Em sintonia com a conceituação de "tradução literária" desenvolvida por Laranjeira, Toury (2012) faz uma esclarecedora distinção entre “tradução de textos literários” e "tradução literária”. Com o primeiro termo, “tradução de textos literários”, Toury denomina a tradução de textos que, na sua cultura de origem, podem ser classificados como literários, independentemente de, na cultura receptora, serem adaptados para fins de aceitabilidade; com o segundo, o estudioso se refere ao tipo de tradução através da qual textos de quaisquer gêneros adquiram características que, pelo menos na cultura de chegada, sejam consideradas de natureza literária. Como exemplo de "tradução de textos literários” Toury cita o caso do limerick, tipo de composição poética tida como produto exclusivo da literatura medieval inglesa. Datando do início do século XVIII e popularizado no século XIX por Edward Lear, o limerick se caracteriza por ser anônimo e apresentar conteúdo obsceno. Em razão da diferença existente entre os sistemas literários em questão, a versão traduzida poderá carecer - e muitas vezes carece - dos traços característicos mais marcantes desse tipo de poema, quais sejam a estrutura com cinco versos, o anapesto e o punch line, frase final desse tipo de composição poética que tem por função produzir o efeito cômico, que também lhe é característico (Não consegui descobrir se, na análise de textos poéticos, é essa a terminologia empregada). Considerando que, como define Toury (2012, p. 199), no caso da tradução de textos literários, “o objetivo é a retenção (ou melhor, a reconstrução) da rede interna de relações do texto 
fonte” ${ }^{77}$, a versão traduzida será categorizada como uma composição poética que, a despeito das modificações estruturais sofridas, guarda bastantes semelhanças com a forma estrangeira que lhe deu origem e, por essa razão, poderá ser categorizada como tal. Já para ilustrar o conceito de "tradução literária”, Toury utiliza dois exemplos diferentes: 1) ensaios versando sobre filosofia e astronomia, estes últimos sendo hoje categorizados como científicos, que, durante a Idade

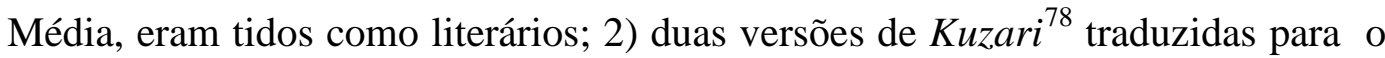
hebraico, em que estratégias e normas tradutórias diferentes foram empregadas, sendo uma delas literária, o que evidencia, segundo Toury, que foram as distintas propostas tradutórias, ou as diferentes classificações do texto de partida que determinaram essas duas versões e não quaisquer características inerentes ao texto de partida, como em tese, se possa supor.

Uma ideia que permeia os debates acerca do papel desempenhado pelo tradutor nos cenários literário e editorial é a sua posição em relação à atividade tradutória. Seria o tradutor coautor das obras que traduz? Em entrevista reproduzida no blog da Parábola Editorial ${ }^{79}{ }^{80}$, mas concedida ao periódico Cadernos de Literatura em Tradução da USP (n. 16, 2016), Marcos Marcionilo, tradutor e sócio-editor da empresa, fala da importância do tradutor para o mercado editorial, atribuindo-lhe o status de coautor do texto de origem. Isto, porque, segundo ele, para "chegar à melhor expressão possível em português brasileiro daquele conteúdo [...] artístico [...] que o autor da obra na língua fonte concebeu” (MARCIONILO, 2016), o tradutor, além de conhecer as línguas envolvidas e ser íntimo o bastante do texto fonte, precisa estar disposto a realizar as pesquisas necessárias e lançar mão dos recursos tecnológicos desenvolvidos especificamente para a atividade tradutória. Recorrendo à dicotomia conteúdo/forma e ao conceito de fidelidade, ambos postos em xeque pelas abordagens de orientação pós-

\footnotetext{
77 “[...] the focus is on the retention (or, better, reconstruction) of the source text's internal web of relationships [...]. (TOURY, Gideon. Descriptive Translation Studies and Beyond. NY/Amsterdam: John Benjamins, 2012, p. 197-211.

${ }^{78}$ Obra do escritor medieval judeu Yehuda Hajevi, construída em forma de diálogos e que versa sobre a religião judaica. Escrito primeiramente em árabe, foi traduzida para o hebraico e para outras línguas. (Fonte: https://pt.wikipedia.org/wiki/Kuzari. Acesso em 15/02/2020.

${ }^{79}$ Disponível em https://www.parabolablog.com.br/index.php/blogs/a-importancia-da-traducaopara-o-mercado-editorial?tmpl=component\&print=1\&format=print. Acesso em 10/12/2019.

${ }^{80}$ Sediada na cidade de São Paulo, a Parábola Editorial, fundada em 2001, especializou-se em obras acadêmicas voltadas para a área de Letras.
} 
estruturalista, Marcionilo alega que só se atendo ao que está dito no texto fonte, porém com autonomia suficiente para utilizar os recursos que a língua alvo oferece para executar esse processo de recriação, o tradutor poderá “dar ao leitor a plenitude maximamente alcançável do que o autor diz na forma mais legítima, na forma mais compreensível na língua-alvo” (MARCIONILO, 2016). O editor/tradutor defende que a condição de coautor que ele confere ao tradutor precisa ser amplamente divulgada para que o leitor não veja mais a tradução como uma atividade acessória e passe a vê-la como uma "intervenção possibilitadora da existência da obra em determinado universo linguístico" (MARCIONILO, 2016, grifo original). Afinal, sem a tradução, ou melhor, sem a intervenção profissional do tradutor, como ler, ou sequer ter notícia de uma obra produzida em outra comunidade linguística?

Conceber o tradutor como coautor da obra traduzida é um tema que, por ser sensível, merece uma reflexão mais acurada. Pelo que se percebe, o conceito de "autoria” formado pelo senso comum está intimamente ligado à ideia de “criação”, ou seja, está associado à ideia de “fazer existir; dar origem [a], a partir do nada, ${ }^{81}$, que, do ponto de vista conceitual, não contemplaria o tradutor, cujo trabalho, quer queira ou não, deriva do trabalho do autor, independentemente de o texto de partida estar repleto de referências de outros textos já existentes. A fim de demonstrar que autor e tradutor dividem o mesmo espaço textual, socorro-me do que diz o teórico belga Theo Hermans (1996) acerca do assunto. Para ele, a tradução, ou seja, o produto do trabalho do tradutor, ou ainda, a “obra” (opera = trabalho) do tradutor, caracteriza-se pelo hibridismo, traço que merece aqui um breve comentário. O hibridismo que marca o texto traduzido se manifesta na sobreposição da voz do autor e da voz do tradutor, entendendo-se "voz", aqui, como tudo o que cada um desses agentes traz consigo e deixa ecoar em seus respectivos textos. Por conseguinte, o hibridismo que caracteriza o texto traduzido consistiria na justaposição do habitus do autor e do habitus do tradutor. Hermans exemplifica a coexistência dessas duas identidades discursivas, por assim dizer, com a tradução para o latim da obra de René Descartes Discours de la méthode (1637). Ao elaborar a referida obra em francês, sua língua materna, o autor parece

\footnotetext{
${ }^{81}$ Dicionário eletrônico Houaiss 3.0.
} 
ter tomado uma atitude de cunho político com o propósito de produzir um texto acadêmico no seu próprio vernáculo, quando, pelo que se pode inferir, a praxe era fazê-lo em latim, então a língua do conhecimento. Assim sendo, talvez ciente de que aquele seu texto em francês por certo seria traduzido para o latim, Descartes declara verbalmente que todo o conteúdo da obra estava sendo redigido, em primeira mão, na língua francesa, e que uma versão em qualquer outro idioma tratar-se-ia de uma tradução. Na versão em latim, porém, a frase em questão foi removida e, pelo que se pode inferir, tal omissão teve o intuito de imprimir nesse texto, na verdade uma tradução, a chancela da “confiabilidade do original”. Além de “apagar” do texto em latim o “indesejado” status de tradução e, a reboque, ocultar a intervenção de um tradutor, a remoção do enunciado metalinguístico parece ter servido também para reconduzir o latim à sua condição hegemônica de “língua do saber”. Nesse caso, a omissão da voz do tradutor tem por função proporcionar ao leitor a ilusão de estar “ouvindo” no texto somente a voz do próprio autor. Ou seja, manteve-se o autor e removeu-se o "coautor", se considerarmos o tradutor como tal, assim como o fez o tradutor/editor Marcos Marcionilo. Na versão inglesa de Discours de la méthode, no entanto, a frase de Descartes é mantida, fazendo com que a tradução esteja textualmente manifesta, como comenta Hermans (1996, p. sem número de página) ${ }^{82}$ :

A anomalia de se ler a versão de um texto em inglês no qual se declara, em inglês, que foi, na verdade, escrito em francês cria uma lacuna de credibilidade que o leitor só pode superar se lembrando que aquele texto é, claro, uma tradução. Ao fazê-lo, o leitor também percebe que a voz que produz aquela frase não pode pertencer a Descartes, ou apenas a Descartes. Há claramente uma outra voz em operação, uma voz que não devemos ouvir, que faz ecoar e imita a primeira voz, mas que nunca coincide totalmente com ela. E a outra voz está lá no texto, em cada palavra.

Após decantar o hibridismo que, como aponta Hermans, caracteriza o texto traduzido, separando as vozes que o compõem, é importante que se destaquem

\footnotetext{
${ }^{82}$ The anomaly of reading an English version text which declares, in English, that it is actually in French creates a credibility gap which readers can overcome only by reminding themselves that this is, of course, a translation. But in so doing, the reader also realizes that the voice producing the statement cannot possibly belong to Descartes, or to Descartes only. There is, clearly, another voice at work, a voice we are not meant to hear, which echoes and mimes the first voice, but never fully coincides with it. And the other voice is there in the text itself, in every word of it. (HERMANS, 1996, sem número de página) Available at https://core.ac.uk/download/pdf/1668908.pdf.
} 
dois aspectos: se ao autor se atribui a “criação” de um texto, ao tradutor se deve atribuir a "criatividade” de recriar na língua/cultura meta todo aquele universo literário, seja prosa ou poesia, engendrado pelo autor "a partir do nada”, como conceitua o dicionário Houaiss. A dificuldade e a engenhosidade do trabalho do tradutor, insisto, residem justamente em partir de algo que já existe, isto é, residem no ato de "criar de novo" e em tudo o que essa operação envolve. A “obra” do tradutor, em suma, consiste em interpretar o texto fonte e reescrevê-lo na língua da cultura receptora tentando driblar todos os obstáculos linguísticos e culturais, de modo a oferecer ao leitor da tradução experiência similar à que teve 0 leitor do texto de origem. Se, para distinguir a figura do autor da figura do tradutor, Hermans (1996) optou por ter o texto traduzido como campo de observação, Pym (2011) volta para os diferentes processos cognitivos ocorridos durante os dois tipos de produção textual aqui em foco: a autoria e a tradução. Pym, então, recorre a Immonen (2006) que, por meios de experimentos e tendo por parâmetro a "duração de pausas que precedem a formulação de unidades sintáticas (palavras, sintagmas e orações)” (IMMONEM; MÄKISALO, 2010, p. 45), detectou que tradução e escrita autoral são produtos de processos mentais diferentes. Pym conclui que essa diferença entre o processo cognitivo da escrita monolíngue (autoria) e o da escrita bilíngue (reescrita tradutória) pode explicar por que alguns escritores, quando percebem que a criatividade está bloqueada, passam a traduzir para destravá-la. Fechando o artigo, Pym explica por que lamenta o fato de que o tradutor não seja visto como coautor. Segundo ele, cada cultura desenvolve uma espécie de "modelo de tradução" que estabelece uma “distinção operacional entre tradução e autoria” (PYM, 2011, p. 42). Esse modelo, por sofrer mudanças ao longo do tempo e por variar de cultura para cultura, precisa ser regularmente testado, para que a distinção entre os dois processos de produção textual esteja sempre empiricamente em consonância com o modelo vigente. Pym argumenta ainda que os "modelos de tradução", de um modo geral, são fundamentados no binarismo conceitual que estabelece limites entre as várias culturas nacionais. Assim, para penetrarmos na cultura estrangeira cujo vernáculo o leitor não domina, é necessária a intervenção de um mediador, e esse mediador é o tradutor que, na condição de profissional bilíngue, é conhecedor das culturas e línguas envolvidas e, com isso, possibilita essa interconexão. 
Sette (2003), ao abordar a possibilidade de se conferir ao tradutor o status de autor ou coautor, traz à baila a ideia de que a identidade do tradutor, visto como um "mero transportador de significados”, é marcada por um sentimento de “melancolia”. Segundo a tradutora e professora da PUC-Rio, essa "melancolia” pode ser definida como um sentimento de "perda", ou até mesmo de "luto", que advém da visão criada pela doxa, ou seja, da ideia formada pela sociedade, de acordo com a qual o tradutor não é o produtor do texto traduzido, como bem esclarece Sette (2003, p. 1):

[o] descaso [com o tradutor e a tradução] é fruto de uma visão tradicional de tradução, a qual considera o texto original superior e imutável; tradutor como um transportador dos significados originais que deve neutralizar ao máximo as marcas de sua operação sobre ele.

A autora, porém, propõe um "tratamento" para “a alma enlutada e melancólica” que a doxa cunhou no tradutor: cultivar a verdadeira identidade do tradutor, identidade esta que surgirá a partir do estabelecimento da diferença entre o que é e do que faz o autor e do que é e do que faz o tradutor. Sette, então, socorrendo-se dos estudos culturais, afirma que essa "melancolia identitária” do tradutor só será curada quando ele compreender o que não é, ou seja, entender que não é autor e que a sua função é transformar a obra autoral numa outra língua, numa outra cultura. O seu papel, diverso do desempenhado pelo autor, é tão valioso quanto, mas possui propósito diferente e se reveste de natureza igualmente diferente. Assim, argumenta Sette (2003, p. 7):

[S]er tradutor é, em primeiro lugar, não ser o autor. O que é preciso matar é a supervalorização do autor [em relação ao tradutor], uma vez que esta provoca o esvaziamento do ego. Para tanto, o tradutor deve ser o primeiro a reconhecer a complexidade e a importância do seu trabalho e valorizar-se[.] O tradutor é fundamental para o autor e sua obra, uma vez que, sem ele, o autor veria o seu trabalho restrito ao território dos falantes de sua língua materna.

Feitas essas considerações acerca da ideia de o tradutor ser ou não coautor da obra estrangeira traduzida, passo a expor aqui a minha posição sobre o assunto. Muito provavelmente por estar, de certa forma, imbuída do conceito de tradução formado pela sociedade, conceito este que associa a ideia de autoria à ideia de “criação primígena”, nunca concebi o tradutor como coautor da obra traduzida. Hoje, muitos textos teóricos depois, mesmo mantendo a mesma opinião, entendo, 
porém, ser importante acrescentar alguns fatores sobre os quais passo agora a expor. Ao fator “criação primígena” adiciono o fator “cronologia” para sustentar a ideia de que o tradutor não deva ser considerado coautor, uma vez que, para que se possa afirmar que um determinado texto é uma tradução, há que se identificar o texto estrangeiro que lhe deu origem, aquele que foi vertido para a língua meta e reescrito - e, em muitas instâncias, adaptado - conforme as normas tradutoras vigentes na cultura de chegada. A propósito do quesito “ordem cronológica”, não me aterei aqui às chamadas pseudotraduções que carecem do texto de partida, uma vez que não são genuinamente uma tradução no sentido estrito do termo. À sequência temporal que identifico na relação entre texto fonte e texto traduzido, adiciono o fator "ética” partindo da interessante reflexão feita por Pym (2010) que, por sua vez, toma como ponto de partida o conceito de "autoria" desenvolvido pelo sociólogo canadense Erving Goffman. Sob o ângulo da pragmática, Goffman, como descreve Pym (2010), associa a ideia de "autoria” ao conceito de "responsabilidade", ou seja, o autor é "alguém cuja posição é estabelecida pelas palavras ditas, ou alguém cujas crenças foram verbalizadas, ou mesmo alguém que se compromete com o que as palavras dizem”83 (GOFFMAN apud PYM, 2010, p. 33). Similarmente, e em tese, o tradutor também pode ser responsabilizado, caso alguma adulteração no texto fonte vier a ser identificada pelo detentor dos direitos autorais da obra estrangeira. Assim, entende-se que o tradutor seja responsável por cumprir o projeto tradutório encomendado pela casa editorial, projeto esse que, na maioria das vezes, consiste em zelar pela preservação de boa parte do conteúdo do texto de origem, tarefa para cuja execução ele precisará se valer de operações linguísticas e boas horas de pesquisa. A fim de ilustrar a responsabilidade do tradutor, pode-se citar o caso do escritor canadense Grant Patterson, que move uma ação contra a Fonte Editorial por ter tido o conteúdo de suas obras Southern Cross e Back in Slowly totalmente invertido na versão para o português. De perfil conservador, o autor faz refletir no seu texto a sua visão de mundo, verbalizada por intermédio de sua narrativa e das falas de seus personagens. No entanto, na versão traduzida do texto ficcional, que tem por pano de fundo o cenário político brasileiro durante o processo que

\footnotetext{
${ }^{83}[\ldots]$ someone whose position is established by the words that are spoken, someone whose beliefs have been told, someone who is committed to what the words say.
} 
culminou no impeachment da ex-presidente Dilma Rousseff, a narrativa toma um sentido totalmente oposto ao tomado pelo texto de origem, mostrando apoio a então presidente ao invés do tom crítico que Patterson imprime na sua obra. A Fonte Editorial tenta se eximir de responsabilidade atribuindo-a completamente ao tradutor, Daniel Costa. Este, por seu turno, orgulha-se das alterações feitas na obra de Patterson alegando que o autor deveria agradecer-lhe pelas "retificações" feitas no texto de origem por meio da tradução, uma vez que o autor, segundo Costa, “tem uma visão alienada” ${ }^{84}$. O que é interessante observar é que, segundo a matéria do site Gauchazh, consultada aqui como fonte, o réu da ação é a casa editorial e, não, o tradutor, agente que assumidamente promoveu as alterações, objeto da referida ação judicial. Isso provavelmente se deva ao fato de que é praxe no mercado editorial, no brasileiro pelo menos, o tradutor assinar um termo de cessão de direitos autorais. A partir da assinatura desse documento, a casa editorial assume toda a responsabilidade por todo o processo de confecção e publicação da obra literária traduzida, que aqui é examinado. A despeito disso, a Fonte Editorial, conforme relata a matéria, tenta atribuir única e exclusivamente ao tradutor a responsabilidade pela adulteração infligida à obra de Patterson. A sanção sofrida pelo tradutor, porém, veio por parte da editora, que dispensou seus serviços.

Com base nas argumentações apresentadas nos parágrafos anteriores, penso ser legítimo afirmar que a figura do tradutor - bem como o papel que desempenha na sociedade e a tarefa que executa - é vista sob quatro perspectivas: a formada pela doxa, a elaborada pelos Estudos da Tradução, a concebida pelo mercado editorial e a abraçada pelo campo jurídico-legislativo. Segundo a percepção social, o tradutor é o profissional bilíngue que, de forma distanciada, imparcial, impessoal, transfere para a língua e para a cultura tradutora o conteúdo do texto fonte. No âmbito dos Estudos da Tradução, dividem-se as opiniões: alguns teóricos, como a brasileira Rosemary Arrojo, defendem a condição do tradutor como autor; outros, como o australiano Anthony Pym e a tradutora e professora universitária brasileira Lourdes Sette, alegam que a importância do

\footnotetext{
84 Disponível em <https://gauchazh.clicrbs.com.br/cultura-e-lazer/noticia/2020/04/autorcanadense-processa-editora-por-incluir-trechos-petistas-em-seu-livrock9f73yiw000001s0q943599t.html>. Acesso em 13/07/2020.
} 
tradutor e a complexidade de seu ofício, a tradução, precisam se tornar públicos para, a longo prazo, promover uma mudança na percepção da doxa em relação ao tradutor e à tradução. O mercado editorial, por seu turno, tenta de todas as formas apagar a figura do tradutor e as operações linguísticas que produziram o texto traduzido, ou, nos dizeres de Venuti, tornar invisíveis o tradutor e a tradução: além de não lhe dar o devido destaque e não lhe permitir uma manifestação textual por meio de elementos paratextuais, por exemplo, o mercado editorial exige que o tradutor, junto com o contrato para a tradução de uma obra estrangeira, assine também um termo de cessão de direitos autorais. Entendo ser esse documento uma espécie de "medida protetiva" tomada pelas editoras brasileiras para se isentarem de pagar ao tradutor os direitos autorais da tradução. Esse termo de cessão de direitos autorais, pelo que se pode inferir, tem por motivação proteger-se de uma obrigação contratual com base no que prevê o inciso XI, do artigo $7^{\circ}$, da Lei 9610/1998 (ver capítulo 2 deste trabalho), que considera a tradução “criação intelectual nova”. Dessa forma, vê-se verbalmente expressa no texto legal a concepção formada pela esfera jurídico-legislativa em relação à figura do tradutor e o seu trabalho, marcado pela criatividade; o autor de uma obra nova, ou seja, aos olhos do campo jurídico-legislativo, o tradutor é produtor de uma nova obra, derivativa, sim, mas que consiste na transformação de uma obra estrangeira, esta a obra de origem. É necessária a intervenção criativa e a expertise linguística do tradutor.

No que se refere ao perfil do tradutor, outro tema que julgo pertinente diz respeito à sua formação acadêmica e sua experiência profissional. Segundo relataram Renata Pettengill (2018) e Silvia Leitão (2018), se no passado não se cobrava do tradutor algum conhecimento específico, hoje em dia, ter uma qualificação pode vir a ser um diferencial e pode pesar na hora de se escolher o tradutor, embora não seja uma exigência formalmente feita pelas casas editoriais. Considerando que as editoras contam com serviços de revisão textual, independentemente do nome que receba esta atividade, privilegiar-se-á o domínio que o tradutor tem em relação ao tema, ao gênero ou autor a ser traduzido, visto que o aspecto textual (incluindo aí a tradução em si) será lapidado, em primeira instância, pelo copidesque e, ato contínuo, pela revisão. No âmbito do estado do Rio de Janeiro, no momento apenas a PUC-Rio oferece cursos em nível tanto de 
graduação quanto de pós-graduação lato sensu especialmente organizado e planejado com a finalidade de formar tradutores. Para tanto, a universidade conta com um corpo docente qualificado para ministrar as disciplinas que compõem as respectivas grades curriculares (da graduação e da especialização). Em entrevista realizada em novembro de 2018, a Prof ${ }^{a}$ Teresa Dias Carneiro, da PUC-Rio, onde atua na formação de tradutores e pesquisadores da tradução, ressaltou o caráter pragmático do curso de graduação em Letras da instituição na modalidade tradução, criado em 1968. Dotado de identidade e objetivo inequívocos, que é o de formar tradutores, o curso alia uma formação acadêmica que abrange, ao mesmo tempo, o campo humanístico mais amplo das Letras e o dos Estudos da Tradução - este por meio de disciplinas voltadas para o desenvolvimento de diversas competências, dentre as quais se destacam as de leitura, de escrita, tradutória e cultural - com a preocupação de preparar o aprendiz para o mercado de trabalho, inclusive procurando facilitar a sua inserção nesse mercado pela via de estágios supervisionados. Ao longo de sua vivência docente nesta universidade, Carneiro teve a oportunidade de ver alunos seus começarem a traduzir para grandes editoras. Acrescentou ainda que o curso da PUC-Rio "tem a preocupação de oferecer um leque bem amplo de possibilidades”. Tal formação, além de ir ao encontro do que informaram as editoras entrevistadas, corrobora o que diz Britto (2003, p. 91), quando indagado sobre as habilidades que, de um modo geral, são exigidas de um tradutor e, em particular, quando se trata do campo da tradução literária:

Basicamente, o que é necessário para ser tradutor é uma certa paixão pelo trato da palavra, o gosto pela escrita, o gosto pela leitura, e uma certa curiosidade intelectual generalizada. [...] [O] bom tradutor é aquele que na infância foi leitor de enciclopédias e dicionários. Esse interesse quase indiscriminado com relação a todos os assuntos possíveis é uma qualidade muito boa para quem pretende se tornar tradutor profissional. (BRITTO, 2003, p. 91)

Conforme relatou a Prof ${ }^{\mathrm{a}}$ Lourdes Sette (2018), coordenadora do curso de pós-graduação lato sensu Tradução (Português-Inglês) - Formação para o Mercado de Trabalho, da PUC-Rio, o curso está estruturado em módulos que abordam diferentes modalidades de tradução, gêneros textuais e assuntos específicos. O currículo contempla uma gama variada de disciplinas que inclui, além da tradução literária, tradução de textos não literários, categoria que 
contempla gêneros como biografia, textos jornalísticos, além dos que se classificam como técnico-científicos. É importante ressaltar que todas as disciplinas de prática de tradução são embasadas em modelos teóricos e promovem reflexões críticas, visando a fornecer aos futuros profissionais um aparato analítico que lhes permita adequar as estratégias empregadas às necessidades de cada projeto tradutório. Ao contemplar o cenário editorial existente, campo profissional a que o tradutor com formação almeja, indago qual seria o tradutor escolhido diante da seguinte situação: de um lado, um tradutor com uma excelente formação acadêmica na área de tradução, mas com uma tímida experiência; do outro, um tradutor com nenhuma formação acadêmica em tradução, mas com um vasto repertório de traduções. A conclusão a que posso chegar, tomando por base tanto o material consultado quanto os dados gerados pelas entrevistas, é que o tradutor que atualmente presta serviço para editoras, de um modo geral, possui alguma formação acadêmica, mas poucos, pelo menos dentre os que traduzem para o Grupo Editorial Record, possuem formação acadêmica específica em tradução ou sequer, arrisco afirmar, têm algum conhecimento teórico acerca da atividade. São, pelo que posso inferir, profissionais bilíngues, conhecedores de um determinado assunto, gênero literário ou autor, e que apresentam talento redacional na língua meta, habilidades que o credenciam a atuar no campo editorial.

Sobre a teoria da tradução ensinada nos cursos universitários voltados para a formação de tradutores, o professor e tradutor Mário Laranjeira (2003) diz não crer numa teoria da tradução de caráter estrito que, aplicado como uma fórmula matemática, possa encontrar as melhores soluções para os impasses tradutórios levando, dessa forma, ao produto final desejado. Na opinião de Laranjeira, os textos que podem efetivamente contribuir para um embasamento teórico do tradutor prático são "reflexões de teóricos e de tradutores experimentados sobre a atividade tradutória, suas relações com a linguística, a semiologia, a psicologia, a teoria literária etc.” (LARANJEIRA 2003, p. 121). Por sua vez, Paulo Britto (2003) atribui à falta de leitura teórica a postura do tradutor que consolida as suas opções como as únicas possíveis. Pelo que se depreende não só do comentário de Britto, mas também dos depoimentos das professoras, uma formação acadêmica e um conhecimento teórico da tradução, seja em nível de graduação ou de pós- 
graduação, proporcionarão ao tradutor, literário ou técnico, uma amplitude de visão acerca da prática tradutória.

A propósito da relação entre teoria da tradução e prática tradutória, Britto afirmou haver, pelo menos à época em que concedeu a entrevista, "uma situação de divórcio entre tradutor prático e teórico da tradução” (BRITTO, 2003, p. 9293), atribuindo a ambas as partes a responsabilidade por tal conflito. Por um lado, alega Britto, muitos tradutores literários, por se julgarem prepostos de algum autor estrangeiro, não admitem que se questionem suas escolhas. Afinal, são eles, os tradutores tidos como especialistas em tal ou qual autor, ou seja, que possuem "um acesso direto, quase sobrenatural, às verdadeiras intenções do autor" (BRITTO, 2003, p. 92). Para o tradutor e professor entrevistado, essa é uma armadilha decorrente da ideia de "tradução privilegiada”, ou seja, a tradução feita pelo tradutor que se considera e se autointitula o verdadeiro - e talvez o único representante daquele autor estrangeiro na língua/cultura receptora. Essa visão equivocada e egocêntrica seria dissipada mediante algum grau de leitura teórica e uma posterior reflexão sobre o tema.

A propósito da remuneração dos tradutores praticada pelo mercado editorial, parece ser legítimo afirmar que é de praxe as casas editoriais estabelecerem um valor por lauda, esta com um formato já preestabelecido pelas próprias empresas. Acerca desse assunto, Benedetti (2003) faz uma interessante reflexão em que compartimenta a tradução em duas categorias: a tradução meio e a tradução fim. A primeira é a praticada em quaisquer setores da seara técnica, em que a tradução é necessária para que todos os agentes ali envolvidos possam ter acesso, por exemplo, à mesma versão (traduzida, no caso) de manuais, instruções e protocolos. Ao se padronizarem esses textos, evitar-se-á que interpretações equivocadas venham a pôr em risco não só os profissionais ali implicados, mas também futuros usuários dos equipamentos, se for o caso. O setor meio, como denomina a autora, embora integre a rede de atividades ali formada para uma determinada finalidade, a atividade tradutória não pertence ao mesmo ramo de atividades da empresa contratante. A tradução de uma bomba de sucção que bombeia óleo in natura para os dutos, por exemplo, é feita por um tradutor especializado nesse nicho da tradução técnica e será utilizada por técnicos e engenheiros. Ainda que, no texto traduzido do manual os usuários detectem 
alguma inadequação sintática ou lexical, por exemplo, não se sentirão a cavaleiro para criticar e confrontar o tradutor. Isso porque há um entendimento de que as áreas, embora partes da mesma cadeia, são autônomas e estão sob responsabilidade de seus respectivos agentes. A tradução fim, por sua vez, é a praticada para o mercado editorial e para os estúdios de legendagem e de dublagem, em que a tradução é um fim em si mesmo. Em razão disso, é parte integrante do processo de confecção do produto final, seja uma obra traduzida ou um filme dublado ou legendado e não apenas uma etapa auxiliar da rede de atividades ali gerada. No setor fim, como argumenta Benedetti, não se pode dissociar a tradução do produto final, pois:

[a] tradução-fim é [...] feita com o intuito de se transformar num produto que será posto à venda, produto este cuja razão de ser decorre da própria tradução [...]. O usuário final a "compra” inserida no seu suporte: um sem o outro não tem razão de ser, o que faz da própria tradução um produto final. Sua finalidade é reproduzir uma obra original numa outra língua, obra esta também destinada ao consumo final pelo usuário. (BENEDETTI, 2003, p. 23-24)

O quadro comparativo abaixo objetiva demonstrar as diferenças mais significativas da atividade tradutória nos setores meio e fim, conforme descrição de Benedetti. 


\begin{tabular}{|c|c|}
\hline Tradução meio & Tradução fim \\
\hline $\begin{array}{l}\text { - Considerando que os contratantes são, via } \\
\text { de regra, grandes empresas, entram em } \\
\text { jogo altos valores monetários, podendo } \\
\text { elevar o valor pago pela tradução. } \\
\text { - O setor meio é composto por empresas } \\
\text { que atuam nos mais variados ramos de } \\
\text { negócio, mas que não possuem relação } \\
\text { alguma com a produção textual em si. Há, } \\
\text { portanto, uma completa ausência de } \\
\text { interferência por parte das empresas do } \\
\text { setor meio sobre a tradução encomendada. } \\
\text { Em razão desse distanciamento e dessa } \\
\text { separação de competências, não há } \\
\text { competição entre os agentes que circulam } \\
\text { no setor meio e o tradutor. } \\
\text { Como consequência do item anterior, no } \\
\text { setor meio, o tradutor é visto pelo cliente } \\
\text { (leigo e sem qualquer relação com o } \\
\text { mercado editorial) como um especialista. } \\
\text { Em razão disso, no setor meio, a } \\
\text { remuneração do tradutor, segundo } \\
\text { Benedetti, tende a ser mais elevada, } \\
\text { havendo, inclusive espaço para uma } \\
\text { negociação entre as partes. }\end{array}$ & $\begin{array}{l}\text { - A instabilidade que historicamente marca } \\
\text { o cenário econômico brasileiro coloca em } \\
\text { risco qualquer atividade, incluindo a } \\
\text { exercida pelo mercado editorial, } \\
\text { sobretudo para as casas editoriais, por } \\
\text { terem um menor volume de capital em } \\
\text { relação às empresas que atuam em outros } \\
\text { ramos. } \\
\text { - Benedetti identifica no setor fim uma } \\
\text { assimetria de forças entre as empresas } \\
\text { (editoras, por exemplo), que são pessoas } \\
\text { jurídicas, e os tradutores, normalmente } \\
\text { pessoas físicas, contratadas por obra, } \\
\text { como freelancers. No caso das editoras, } \\
\text { boa parte de seus funcionários têm } \\
\text { formação em comunicação social, com } \\
\text { habilitação em produção editorial. Na } \\
\text { qualidade de "profissionais do texto", } \\
\text { muitos editores traduzem e, com isso, } \\
\text { passam a competir com os tradutores, } \\
\text { estes "profissionais da linguagem”. } \\
\text { Como resultado dos dois itens anteriores, } \\
\text { o tradutor é visto no setor fim como um } \\
\text { mero contratado para executar uma tarefa } \\
\text { que compõe a cadeia ali em curso. Por } \\
\text { essa razão, a editora (ou o estúdio, no } \\
\text { caso da tradução audiovisual) assume a } \\
\text { função de patrono, responsável por ditar o } \\
\text { preço do serviço. }\end{array}$ \\
\hline
\end{tabular}

Observar tanto o ingresso do tradutor no mercado editorial quanto a sua escolha para a tradução de uma determinada obra é, segundo penso, de suma importância para uma análise sociológica da tradução, considerando as três subáreas, como propõe Chesterman (2017, p. 309). Portanto, alocar um tradutor na dinâmica produtiva de uma casa editorial é vê-lo como peça na engrenagem que se põe em movimento para produzir obras traduzidas (a sociologia da tradução como produto), processo em que estará operando em consonância com outros profissionais, incluindo outros tradutores, no caso da tradução em equipe (sociologia dos tradutores) e executando uma tarefa que se categoriza como um processo cognitivo (a sociologia do traduzir). A casa editorial costuma contratar o tradutor por indicação, como confirmou Teresa Dias Carneiro (2018) que, no entanto, não descartou a possibilidade de algumas casas editoriais promoverem 
testes para esse fim. A editora Renata Pettengill (2018), por seu turno, relatou que, em fins da década de 1980, ingressou no mercado editorial após ver um anúncio na seção de classificados de um jornal em que a Record convocava candidatos ao cargo de revisor. Já na empresa, foi-lhe oferecida uma tradução, a qual aceitou e, a partir de então, passou a acumular as funções de tradutora e revisora na empresa. Entretanto, segundo informou, o ingresso de um tradutor na Record nem sempre foi um processo que tenha se dado de acordo com algum tipo de critério. No passado - um tempo não marcado cronologicamente por ela - qualquer pessoa que se apresentasse à Record como tradutor era agraciada com um trabalho de tradução. Segundo informou, as traduções produzidas nesse período, quando de um provável relançamento, normalmente geram despesas adicionais com a retradução, tendo em vista a qualidade duvidosa do primeiro trabalho, feito, na maioria das vezes, por leigos. Não fosse por isso, uma revisão da primeira tradução seria suficiente, pois teria por objetivo talvez apenas atualizar e adequar ortografia e vocabulário. Já se prevendo a necessidade de uma retradução, o cronograma de relançamento dessas obras é planejado com a antecedência necessária para ser o mais elástico possível, visto que será uma nova reescrita tradutória com todas as adequações textuais e de pesquisa que o mercado editorial exige.

Ainda sobre a escolha do tradutor para a tradução de uma obra determinada literária, fator que diz respeito mais especificamente à subárea sociologia do traduzir (CHESTERMAN, 2017, p. 309), as editoras tomam por base, conforme alega Anderson (2015, p. 37), “uma série de fatores: sua familiaridade com o assunto, qualificação, experiência, disponibilidade, remuneração etc”. Partindo dos quesitos enumerados pela autora, depreende-se, então, que o tradutor desejado pelo mercado editorial é aquele que conhece o assunto ou o gênero textual a ser traduzido, o que facilitará e agilizará o seu trabalho. Isso, consequentemente, contribuirá sobremodo para que ele cumpra, pelo menos com certa tranquilidade, o prazo acordado com ou estabelecido pela casa editorial, que opera na condição de agente de patronagem, para empregar aqui o conceito e a nomenclatura desenvolvidos por André Lefevere. Segundo informou Silvia Leitão (2018), o Grupo Editorial Record trabalha com um quadro de colaboradores externos, e cada um executa bem um tipo de tradução: biografia, 
ficção, não ficção e outros gêneros. Pelo que se infere da resposta da ex-editora do grupo, a admissão de novos tradutores com o intuito de “oxigenar a equipe", como sugeri em uma das perguntas, parece ser algo raríssimo. A resposta de Renata Pettengill (2018) acerca desse assunto corrobora essa estabilidade do quadro de tradutores da editora, pois, segundo ela, ao contratar um título estrangeiro, já tem em mente, de antemão, o tradutor ideal para aquele texto específico, ou seja, diante de um novo título estrangeiro, Pettengill recorre ao plantel de tradutores já existente na editora, o que revela, eu me arriscaria a dizer, uma certa impenetrabilidade no quadro de tradutores do grupo. Essa seleção prévia do tradutor ideal, como esclareceu Pettengill, pode afetar, inclusive, a questão do custo da tradução, como já observado, visto que o fato de ser considerado o profissional adequado para a tarefa poderá ensejar algum tipo de negociação em torno do valor da lauda. A escolha de quem vai traduzir uma obra, sobretudo se escrita numa língua com pouca oferta de tradutores, leva em conta o currículo do profissional: o quanto domina aquela língua, o quanto conhece o autor ou o gênero literário a ser traduzido, a sua experiência e o seu repertório de traduções.

Uma outra questão que se apresenta é quais os critérios que as editoras adotam para escolher os tradutores que julgam adequados para as obras que pretendem editar. Pelo que pude apurar, dependendo do capital simbólico (mais um conceito bourdieusiano a que se recorre, como já mencionado no capítulo 1 , seção 1.5.1 deste trabalho) que um(a) tradutor(a) tenha, poderá ser esse fator, inclusive, motivo de adiamento da publicação de um título traduzido. O exemplo dado por Silvia Leitão ilustra esse aspecto, pois a editora optou por aguardar o tradutor ideal para a coletânea de aventuras de Sherlock Holmes, fato que será comentado mais adiante. Também vinculado à ideia de capital simbólico está o fator remuneração citado por Anderson (2015). Segundo informou Pettengill (2018), para o tradutor que não ostenta um nome expressivo dentro do campo editorial, o Grupo Editorial Record, por determinação da diretoria da empresa, trabalha com uma tabela em que se firma um valor por lauda, esta, por sua vez, também com formatação pré-estabelecida. A título de exemplo, a editora citou o caso de uma tradução que ela julgou ser adequada para uma tradutora muito cobiçada, mas que costuma cobrar valores muito além das limitações 
orçamentárias do grupo. Segundo Pettengill, tradutores de prestígio, hoje em dia, só prestam serviço para as editoras que podem arcar com esse custo, sendo, no entanto, casos isolados dentro de um universo numericamente considerável de profissionais. Arrisco-me a dizer que, nesse caso, muito provavelmente há negociação para se ter a tradução com uma chancela de prestígio, muitas vezes conferida a um tradutor que, na verdade, tem renome por também ser escritor.

No tocante a essa questão, Pettengill informou que, quando esse tradutor ideal se trata de um tradutor de renome, de valor reconhecido pelo meio editorial, ou seja, com expressivo capital simbólico, esse acréscimo no valor da lauda, de fato, pode ocorrer. Pelo que posso concluir das informações da editora, esse tradutor ideal não é o tradutor comum que regularmente entrega um bom trabalho que esteja dentro dos padrões de qualidade da editora e que, em razão disso, exija poucas alterações do profissional do copidesque. Esse tradutor ideal é aquele cujo trabalho, considerado primoroso, ultrapassa as expectativas da editora, que corresponde ao texto fonte ao ponto de praticamente dispensar o trabalho de copidesque. Cumpre frisar, no entanto, que, a despeito da excelência do trabalho desse tradutor, a etapa do copidesque é inescapável. O trabalho considerado quase irrepreensível desse tradutor confere-lhe cacife suficiente para negociar com a casa editorial um valor de lauda diferenciado, visto que a sua chancela agrega valor ao produto final. O que precisamos ter em mente é que a tradução está sendo aqui analisada também sob uma perspectiva mercadológica. Assim, a produção do livro traduzido, aqui considerado como produto comercial, gera custos, não só com relação ao material empregado, como na remuneração dos agentes envolvidos na cadeia editorial. No caso de se contratar um tradutor renomado com o qual se acordará um valor de lauda mais elevado, como informou Pettengill, a editora procurará uma contrapartida ao recorrer ao copidesque interno, cortando, assim, a despesa com o copidesque externo. Essa compensação financeira, por assim dizer, tem por objetivo evitar que o preço final do livro aumente sobremodo, o que comprometeria as vendas.

Ainda sobre a figura do tradutor ideal, Teresa Carneiro (2018) alega que, de acordo com a sua observação, esse profissional precisa ter um talento autoral. Segundo ela, as editoras buscam um tradutor que, durante o processo tradutório, consiga antever o que vai funcionar ou não na língua alvo, no caso aqui, o 
português do Brasil. Do ponto de vista comercial, para as editoras, esse talento autoral proporcionará o desejado texto fluente que, por sua vez, ensejará uma revisão mais célere. Essa reescrita tradutória inteligível, que proporciona uma leitura sem obstáculos resultará numa disponibilização do produto (livro traduzido) igualmente mais rápida no mercado. Pelos depoimentos da editora e da ex-editora do Grupo Editorial Record, deduzo que os critérios que norteiam a escolha do tradutor para a tradução de um determinado título parecem ser puramente empíricos, pois, dentre os tradutores que já prestam serviço para a empresa, já se sabe “quem traduz melhor o quê”. Assim, com base no histórico de traduções feitas pelo profissional, o editor escolhe o tradutor adequado para o gênero textual a ser traduzido. Observando-se essa distribuição de gêneros pelos tradutores, detecta-se latente o conceito bourdieusiano de habitus, pois o que faz cada tradutor perito na tradução desse ou daquele gênero textual ou desse ou daquele autor é a sua expertise ou, por vezes, a sua formação acadêmica e também a sua trajetória, como o exemplo da tradutora do selo Best Business, graduada em economia. Mais uma vez, flagra-se uma dinâmica coletiva por trás da atividade tradutória, aparentemente individual e solitária: a equipe de editores destina as traduções aos tradutores que, em razão de seus respectivos habiti e competências, poderão realizar a tarefa a contento.

A relação de causa e efeito entre o conceito boudieusiano de habitus e o que a editora considera uma "boa tradução", não só em termos de qualidade textual, mas também em termos de cumprimento de prazo, garantirá, pelo menos no que compete aos agentes dessa etapa, a completude de toda a cadeia produtiva da tradução. Uma tradução inadequada, na visão dos editores do conglomerado Record, afetará todo o processo aqui em foco. O exemplo citado por Leitão (2018), o do caso do tradutor que, por ser profundo conhecedor da obra de Sir Arthur Conan Doyle, seria o profissional indicado para traduzir uma coletânea com quinze aventuras do personagem Sherlock Holmes, ilustra bem essa combinação de domínio de conteúdo e boa elaboração do texto traduzido. Seu talento como tradutor, somado à intimidade que travou com o icônico personagem de Doyle ao longo de sua experiência como leitor, fez com que a Record aguardasse por alguns meses até que o profissional estivesse disponível para traduzir a coletânea. O segundo exemplo fornecido pela ex-editora é o de uma 
tradutora que prestava serviços para o selo Best Business durante o tempo em que Leitão editorou para o grupo. Economista por formação, a tradutora poupava a casa editorial do custo extra com revisão técnica, pois dominava o jargão usado na área, o popularmente chamado “economês”. Renata Pettengill (2018) também citou dois casos que evidenciam a importância do que Bourdieu conceitua como habitus para a busca do tradutor ideal. O primeiro se refere a um engenheiro do IME que, fã de ficção científica e editor da Isaac Asimov Magazine, é sempre a sua primeira escolha para a tradução de obras do gênero. O segundo foi o da escolha do tradutor para o romance Tolos e mortais, do autor britânico Bernard Cornwell. Ambientada na Inglaterra elisabetana, a trama gira em torno da figura e da obra de William Shakespeare, contendo, portanto, em determinados pontos da narrativa, trechos da obra do autor. Para garantir uma tradução rigorosa desses excertos, a editora recorreu à expertise do tradutor José Roberto O’Shea, sugerido à época pela Prof ${ }^{a}$ Marcia Martins, da PUC-Rio. No que tange à retradução de um clássico, por exemplo, o tradutor desejado será alguém com lastro profissional que o avalize para essa tarefa. Entretanto, Pettengill alertou que, embora o fato de o tradutor em questão ser engenheiro e aficionado por ficção científica tenha um peso considerável, de nada adiantaria se ele não tivesse a habilidade de produzir um bom texto traduzido para o português, um texto com a fluência sempre desejada. Pelo que se pode entender, essa habilidade a que Renata Pettengill fez referência parece ser o que a Teresa Dias Carneiro chamou de "talento autoral". Da mesma forma que é crucial aliar domínio do assunto abordado no texto fonte e habilidade redacional na língua de chegada, a questão da pontualidade no cumprimento de prazo também é um importante fator a se considerar. Assim como profissionais de outras áreas, o tradutor precisa associar qualidades que não apenas as relativas ao quesito técnico especificamente. Outras, de natureza ética, como a pontualidade, certamente são sempre observadas pelo contratante. A respeito do quesito "prazo", Pettengill (2018) acrescentou que, no caso de tradutores respeitados, a editora costuma aceitar o prazo proposto pelo profissional. Em contrapartida, o prazo para o copidesque e a revisão são diminuídos, pois a empresa sabe que o texto que virá do tradutor praticamente dispensa reparos. 
Diante do texto finalizado, o leitor nem imagina os obstáculos que o tradutor precisou transpor para que lhe proporcionar aquela leitura prazerosa. Para a tradutora Raquel Zampil (2018), são as dificuldades de cunho cultural, mais até do que as de natureza linguística que se constituem no maior desafio para o tradutor, mesmo o mais experiente. Em consonância com o que disseram Pettengill, Leitão, Carneiro e Sette, Zampil afirmou que não basta ao tradutor ter um bom conhecimento da língua/cultura fonte, mas, sobretudo, ter um bom domínio da língua/cultura alvo. Afinal, para ter condições de adaptar na língua de chegada elementos culturais encontrados no texto fonte, mas inexistentes na cultura de chegada, é condição essencial que o tradutor saiba, ou pelo menos intua, a que recursos oferecidos pela língua alvo recorrer para que lhe seja possível tal adaptação. À guisa de exemplificação dos nós tradutórios de caráter cultural enfrentados pelo tradutor, Zampil citou os neologismos que, além do caráter cultural, apresentam a dificuldade de natureza morfológica que, por sua vez, produz efeitos semânticos. Segundo informou a entrevistada, essa dificuldade se acentua sobremaneira quando se trata da tradução de uma série, que apresenta personagens, fatos, e marcas discursivas recorrentes. Isso porque, além de precisar recriar na tradução termos e expressões presentes no texto de origem, as soluções encontradas precisam ser mantidas em toda a série, não apenas com o intuito de manter uma unidade textual, mas também para impedir que uma indesejada mudança de referencial venha a confundir o leitor. A experiência narrada por ela durante o nosso encontro diz respeito aos neologismos criados pela autora da série Nevermoor: os desafios de Morrigan $\mathrm{Crow}^{85}$, romance de estreia da autora australiana Jessica Towsend e lançado em 2019 pela mesma editora Rocco que lançou a série Harry Potter, sendo que, desta feita, pelo selo Rocco Jovens Leitores. O termo wundersmith, criado para designar os seres fabricantes de wunder, uma espécie de combinação de combustível e tecnologia que move tudo o que há em Nevermoor, dá origem a uma série de outros neologismos com o mesmo componente morfológico, como, por exemplo, wundrous (adjetivo referente a wunder) e wunderground (o metrô de Nevermoor). Mesmo havendo

\footnotetext{
${ }^{85}$ As informações sobre esse romance foram fornecidas por Raquel Zampil, tradutora da obra e entrevistada para este estudo (2018).
} 
em português a palavra “maravilha”, correspondente para wonder, palavra inglesa que parece ter inspirado o neologismo wunder, Zampil optou por ter como termo primitivo o vocábulo “fábula”, de onde pôde criar tanto “fabulônio" para wundersmith e "fabulotrem” para wundergound, como recorrer ao já existente "fabuloso" para wundrous. O que muitas vezes ocorre, segundo informou Zampil, é que o tradutor consegue pensar em mais de uma solução para o mesmo elemento neológico criado pelo autor do texto de origem. Nesse caso, o que ela costuma fazer, segundo informou, é enviar por email ao editor todas as opções que criou, pois, afinal, é sempre dele a última palavra não só sobre qualquer escolha feita pelo tradutor, mas também sobre qualquer emenda feita pelo copidesque. A propósito desse canal aberto entre editor e profissionais do texto, Carneiro (2018) e Sette (2018) informaram não se recordar de alguma ocasião em que, na condição de tradutoras, contataram o editor ou por ele foram contatadas para darem esclarecimentos acerca de suas soluções. O depoimento dessas duas tradutoras experientes e que trabalham para várias casas editoriais sinaliza que os editores, de um modo geral, talvez até se mostrem dispostos a dirimir quaisquer dúvidas que tradutores e copidesques possam ter, mas, creio também que, devido ao ritmo frenético imprimido a cada etapa do processo editorial, esse espaço de interlocução só deva ocorrer em circunstâncias muito especiais.

Ainda em referência aos neologismos, o professor e tradutor Adail Sobral (2003), no posfácio à coletânea de entrevistas que organizou ao lado de Ivone Benedetti, cita um exemplo muito interessante e bastante contemporâneo: o do surgimento e subsequente emprego dos substantivos fathering e mothering. Segundo Sobral, os referidos substantivos, que derivam dos verbos to father e to mother, respectivamente, "surgi[ram] na esteira da criação de parenting a partir de to parent” (SOBRAL, 2003, p. 212). O organizador da coletânea de entrevistas alega que os neologismos fathering e mothering se opõem, respectivamente, a fatherhood e motherhood, pois, enquanto que o sufixo - hood expressa o estado de quem é pai ou mãe, remetendo, assim, ao aspecto biológico, o sufixo - ing expressa o exercício da paternidade ou da maternidade, tendo por referencial quem desempenha a função de cuidar de uma criança, como conceitua o Longman Dictionary of Contemporary English, "as habilidades e as atividades que ser pai 
envolve”86 (2003, p. 576) e "o processo de cuidar de crianças como faz uma mãe»87 (2003, p. 1071). Todo esse trabalho do tradutor será, a seguir, submetido às etapas de revisão, abordadas no próximo capítulo. Passo então a discutir uma outra questão importante que é o grau de visibilidade desse profissional na sociedade, fator essencial para o acúmulo de capital simbólico.

Considerando que o Brasil é um ávido consumidor de literatura traduzida, seria lícito se esperar que os tradutores - e a tradução - tivessem visibilidade e prestígio, mas não é bem isso que se verifica, como podem ilustrar os casos de eventos literários locais como a Bienal do Livro e a FLIP, já mencionados. Na edição de 2017 da, ocorridas na cidade do Rio de Janeiro esteve presente a escritora britânica Paula Hawkins, autora do best-seller A garota no trem. O alto índice de vendas do título, mesmo antes do lançamento de sua versão cinematográfica, só foi possível porque, dentro da cadeia produtiva da literatura traduzida, havia um agente, o tradutor, que viabilizou a leitura do romance escrito em inglês e reescrito em português, língua da cultura tradutora. Entretanto, não consta que, do evento de que participou Hawkins, tenha estado presente nem a tradutora de A garota no trem ou o tradutor de qualquer uma de suas obras traduzidas para o português. Indagada sobre a não participação de tradutores nesses eventos, Leitão respondeu que seria inócuo simplesmente "colocar o tradutor num estande, sem um evento que o contextualize” (LEITÃO, 2018). É bem verdade que, como argumentou Leitão e alega Casanova (2010), uma vez integrante de uma malha de agentes e atividades, o tradutor precisa estar inserido num contexto (editorial) para que sua participação nesses eventos faça sentido. Segundo informou a editora, não é de praxe tradutores participarem de eventos literários, a não ser no caso de obras com vendas estrondosas que tiveram uma repercussão enorme junto ao público, a exemplo de Lia Wyler, tradutora da série Harry Potter, em que o tradutor é circunstancialmente alçado ao status de celebridade, que a presença do profissional é aventada. No entanto, é importante salientar que a condição de "tradutor-celebridade” proporciona ao profissional não apenas os bônus do sucesso. Se, por um lado, os holofotes dos meios de comunicação retiram dos bastidores editoriais o tradutor e a tradução, nos dias de

\footnotetext{
${ }^{86}$ The skills and activities involved in being a father.

${ }^{87}$ The process of caring for children in the way a mother does.
} 
hoje, o meio digital franqueia espaço por intermédio das redes sociais para que o leitor comum manifeste sua opinião - elogiosa ou desfavorável - a respeito do tradutor e da tradução, como abordarei no capítulo 5. Segundo a editora entrevistada, produtivo seria se o tradutor participasse de um café literário em que poderia falar "sobre produção textual, sobre temas ligados à área editorial. Te[ria] que estar dentro de um contexto. Por exemplo, um debate sobre a produção do livro. O tradutor faz parte dessa cadeia” (LEITÃO, 2018, p. 184).

Entendo que, para “contextualizar” o tradutor em eventos literários, seria necessário promover painéis, por exemplo, em que o foco seria o tradutor e o seu trabalho, ocasião em que algum representante da editora apresentasse o profissional. Esse contato direto entre tradutor e público, para surtir o efeito desejado não apenas pela classe, mas também, e talvez principalmente, por pesquisadores da área de tradução que anseiam pelo devido e merecido reconhecimento do profissional e da atividade, precisaria ser planejado e incluído no material de divulgação do evento, para que se aguçasse o interesse do leitor. Direcionar os holofotes sobre a tradução e o tradutor, mostrar os meandros do processo, abrir espaço para que o tradutor fale de si e de sua experiência, seria, a meu ver, uma parte do que eu chamaria aqui de “making of editorial”. Por outro lado, indago se seria de interesse da indústria livreira essa exposição do tradutor e da tradução, uma vez que fazem parte dos bastidores da produção editorial, além de ter o efeito - talvez indesejado - de chamar a atenção dos leitores para o fato de que eles não estão lendo um texto “original”. Em outras palavras, essa visibilidade estaria desfazendo a ilusão do acesso direto, não mediado, ao autor e à obra estrangeiros, como argumenta Lawrence Venuti, em reflexão que será retomada mais adiante.

Ao longo da minha pesquisa, detectei que se justapõem duas visões distintas do tradutor e da tradução: a formada pelos Estudos da Tradução e a formada pelo mercado editorial. A primeira, fruto de algumas décadas de estudo, procura não só dar conta da atividade tradutória sob vários ângulos, mas também delinear os perfis de tradutor que a executam. Essa perspectiva acadêmica, de natureza analítica, vem construindo uma visão da tradução e do tradutor que leva em consideração toda a complexidade já revelada pelas pesquisas feitas. A segunda, formada pela indústria livreira, de viés marcadamente pragmático, vê a 
tradução e o tradutor apenas como peças de sua própria engrenagem. Indago se essas visões são inteiramente excludentes ou se há alguma probabilidade de se integrarem. Talvez essa integração só seja possível por meio de ações afirmativas como a interferência legislativa que gerará efeitos jurídicos, como propõem Ribeiro e o PL 1220/2015, propostas que obviamente requerem aprimoramento, mas que já poderiam servir de ponto de partida.

O depoimento de Leitão traz à baila dois temas que se podem discutir sob o prisma teórico dos Estudos da Tradução: o tradutor como elo da cadeia produtiva da tradução e a invisibilidade desse agente e de sua tarefa, primordial no processo aqui em análise. Em relação ao primeiro, Pascale Casanova (2010, p. 299) alega que:

[u]m entendimento genuíno do papel do tradutor requer situá-lo dentro de um contexto, um continuum de funções e agentes: o tradutor não é um descobridor ou consagrador que opera sozinho, é parte de uma complexa cadeia de mediadores em que se incluem [...] especialistas, editores, críticos, agentes literários etc. ${ }^{88}$

A invisibilidade do tradutor e da tradução, por sua vez, é resultado da desvalorização que a atividade tradutória vem sofrendo historicamente. Vista como secundária e derivativa, a tradução sempre foi concebida como uma falsificação em potencial, como alega Lawrence Venuti (2008, p. 6). O termo “invisibilidade”, como ele mesmo propõe, refere-se não só ao apagamento da figura do tradutor, mas também ao apagamento da atividade que ele exerce, a tradução. Essa neutralização é detectável em dois níveis: o textual e o social. Ao elaborar um texto traduzido de forma a proporcionar ao leitor uma leitura fluente, sem percalços ou estranhamento de qualquer natureza, sustenta Venuti (2008, p. 1), o tradutor dá a esse leitor a ilusão de estar lendo o texto tal como foi escrito na língua de origem, ou seja, "no original”. Assim, imprimindo fluência ao texto traduzido, o tradutor, então, se torna imperceptível aos olhos do leitor e, por conseguinte, da sociedade, visto que esconde o seu trabalho sob o véu da fluência do texto por ele próprio traduzido, sobrando-lhe apenas a discreta menção ao seu nome na folha de rosto ou na ficha catalográfica da obra. No que se refere ao

\footnotetext{
${ }^{88}$ A genuine understanding of the role of translators requires situating them within a context a continuum of functions and agents; translators are not discoverers or consecrators operating alone; they are part of a complex chain of mediators which includes [...] specialists, publishers, critics, literary agents etc.
} 
aspecto social da invisibilidade do tradutor, sempre tendo o cenário tradutório da cultura anglófona (a norte-americana e a britânica) como objeto de análise, Venuti (1995) faz uma observação importante, mesmo se considerando que, entre o panorama por ele descrito e o momento atual, existe o intervalo de mais de duas décadas. Venuti argumenta que, embora tenha se verificado um aumento de instituições e programas voltados para a tradução e os tradutores nos últimos cinquenta anos, “o fato é que o tradutor recebe um reconhecimento mínimo por seu trabalho - incluindo os tradutores de textos capazes de gerar publicidade em razão de terem boa vendagem, de terem ganho prêmios, de serem polêmicos ou de terem sido censurados” (p. 7) ${ }^{89}$.

A questão da fluência do texto traduzido, à qual Venuti atribui a invisibilidade textual do tradutor, é um conceito que suscita polêmica. O copidesque Rodrigo Austregésilo (2019) informou que é comum o tradutor estar comprometido com mais de uma tradução simultaneamente e, com isso, acaba por não ter tempo suficiente para revisar o seu próprio trabalho. Assim, a missão de imprimir ao texto traduzido a "fluência" desejada e perseguida pelo mercado editorial fica integralmente a cargo do profissional do copidesque. A pretexto desse ponto especificamente, o da tão propalada (e criticada por alguns tradutores e por muitos teóricos) “fluência”, indaguei ao entrevistado se, no caso de um texto fonte repleto de características textuais peculiares, como complexas e intencionais inversões sintáticas e sofisticadas construções imagéticas, por exemplo, as editoras, de um modo geral, recomendam que, em nome dessa "fluência" (ou “fluidez”), se devam apagar essas características estilísticas. Austregésilo, então, respondeu que, num caso como esse, de um texto estilisticamente sofisticado, é de praxe o editor alertar tradutores e copidesques sobre essa peculiaridade do autor, solicitando que essa característica seja preservada na tradução e, por conseguinte, na revisão. No entanto, acrescentou que, na sua opinião, obras que apresentem esse requinte estilístico muito provavelmente não fazem parte do acervo que as casas editoriais brasileiras adquiram atualmente. Pelo que se pode concluir, a opção é por adquirir os direitos autorais de obras que tenham maior apelo

\footnotetext{
89 “[...] the fact remains that translators receive minimal recognition for their work - including translators of writing that is capable of generating publicity because it is bestselling, prizewinning, controversial, censored"
} 
comercial, ou seja, que ofereçam leitura mais “digerível” por apresentarem temática e texto mais inteligíveis ${ }^{90}$. Uma vez que um texto mais sofisticado vai na contramão do que se possa classificar como comercial, pode-se deduzir que a incidência desse tipo de literatura no catálogo das editoras brasileiras deva ser baixa. Assim, pelo que se pode depreender da resposta de Austregésilo, o texto de partida da maioria das obras importadas para tradução no Brasil, via de regra, oferece leitura mais acessível, sendo ele próprio, na sua versão primígena, fluido, como adjetivam os agentes do campo editorial, proporcionando, por conseguinte, um texto traduzido igualmente fluido. Desse modo, ao que parece, a maior preocupação da indústria editorial brasileira, como um todo, é a de confeccionar uma versão traduzida a mais próxima possível do original, adaptando apenas o que for necessário.

Por sua vez, a tradutora Ivone Benedetti (2003) faz um interessante comentário no prefácio a uma coletânea de entrevistas com tradutores, organizada por ela em parceria com o tradutor e professor Adail Sobral, obra da qual extraí algumas entrevistas às quais fiz referência neste trabalho. A propósito da invisibilidade textual - um dos dois tipos que, segundo Venuti, afetam a figura do tradutor, conforme mencionado há pouco - Benedetti identifica uma incongruência, pois, conforme argumenta, é justamente na "fluência" (ou "fluidez", como denominam alguns agentes) do texto traduzido que se manifesta a habilidade textual do tradutor. Sobre este ponto em especial, Benedetti conclui que

[a] invisibilidade do tradutor equivaleria a não se enxergar o tradutor. Há aí uma imprecisão. Porque o que não se enxerga, na realidade, é o processo de tradução, é a própria tradução, e essa invisibilidade da tradução é, na realidade, consequência da maior interferência do tradutor sobre o texto, logo, de sua maior visibilidade como produtor textual. Assim, embora socialmente invisível, ele se faz textualmente mais visível, e é o não reconhecimento social da sua presença e da sua necessária participação que leva a não detectar a sua grande presença como manipulador do texto. Portanto, a afirmação teórica de que há invisibilidade quando um tradutor produz um texto fluente corresponde, nos fatos, a uma visibilidade maior sua no processo de tradução: quanto mais fluente o texto, mais influente o tradutor. (BENEDETTI, 2003, p. 27-28)

\footnotetext{
${ }^{90}$ Essa informação fornecida por Austregésilo, de certa forma, conflita com o que disse Bacellar (ver Capítulo 2) sobre a insistência de muitos editores brasileiros em publicar obras de perfil mais erudito, na intenção de formar um público leitor mais intelectualizado.
} 
Benedetti (2003), então, faz distinção entre a invisibilidade do tradutor, de caráter social, e a invisibilidade da tradução, esta de cunho textual. Conforme entende a tradutora, é a invisibilidade no seu matiz social que precisa ser vencida, pois o árduo e importantíssimo trabalho do tradutor precisa ser conhecido e reconhecido pelo grande público, este mesmo público que se beneficia dessa tarefa de tão difícil execução e, como já comentado na introdução deste trabalho, de grande relevância histórica. A invisibilidade de natureza textual, por sua vez, segundo argumenta a tradutora, é a prova material da atuação do tradutor. A fluidez do texto traduzido indicaria, como propõe Benedetti, que o tradutor foi capaz de reescrever o texto fonte em toda a sua complexidade.

A invisibilidade da tradução e do tradutor, a meu ver, reflete-se também nos espaços físicos e virtuais de livrarias e editoras. Ao entrar numa livraria ou acessar seu site ou o de uma editora, o leitor comum que quiser adquirir o último lançamento de Dan Brown ou John Grisham, por exemplo, deverá se dirigir à estante, no caso da livraria física, e no caso do site, clicar no catálogo, onde se encontram os títulos de "literatura estrangeira”. Verifica-se já na nomenclatura escolhida pelo mercado editorial para denominar o gênero a omissão do trabalho do tradutor, cuja atividade foi crucial para que a leitura daqueles títulos fosse possível para o leitor da cultura tradutora. Pelo que se percebe, a tradução ainda é vista pelo mercado editorial como apenas uma das etapas de um processo que, apesar de importante, é simplesmente o elo de uma corrente que se caracteriza sobretudo por uma mecanicidade e que se submete a um escrutínio (copidesque e revisão) para que a harmonia entre os elos dessa corrente não seja afetada e para que o produto final atenda aos padrões de qualidade impostos pelo agente de patronagem (a casa editorial). Visando a dar visibilidade ao tradutor e a tradução, o deputado estadual Jorge Felippe Neto apresentou ao Plenário da Assembleia Legislativa do Rio de Janeiro o Projeto de Lei 1220/2015 que, dentre outras medidas, propõe a substituição do termo "literatura estrangeira” por "literatura traduzida” em seus espaços físicos e virtuais. No que se refere a esse projeto especificamente, é interessante observar que, a despeito de ter sido aprovado em todas as comissões por que passou, recebendo apenas uma única emenda de natureza redacional, o texto, pelo menos até o momento, ainda não foi levado para 
discussão em plenário. Note-se que a assinatura da redação do vencido ${ }^{91}$ data de 28 de março de 2017, ou seja, cerca de três anos atrás. É importante assinalar também que, considerando a matéria do projeto de lei em questão, bastaria que fosse aprovado por maioria simples que, no caso da Alerj que possui atualmente 70 deputados, seria composta por 36 deputados. Em conversa informal, o assessor parlamentar Genario Simões Junior, da Câmara Municipal do Rio de Janeiro e com experiência de mais de trinta anos em elaboração de proposições legislativas, assinalou que o P.L. 1220/2015, por contemplar matéria de natureza financeira de alcance nacional, teria mais chances de produzir efeitos concretos se fosse um projeto de lei federal. Afinal, ao propor que editoras e livrarias procedam a modificações não só em seus espaços físicos e/ou virtuais, mas também nos bens que produzem e comercializam, o projeto, depois de aprovado e já na condição de lei, cria obrigações que orbitam na seara do direito comercial que, conforme dispõe o inciso I do art. 22 da Constituição Federal, é prerrogativa da União legislar.

Um outro aspecto abordado por Venuti acerca do conceito de invisibilidade é o papel fundamental desempenhado pelo leitor nesse processo de apagamento do tradutor e da tradução. Alega Venuti $(2008$, p. 1) que, ao ler um texto traduzido, o leitor segue

a tendência geral de ler traduções principalmente pelo significado, de reduzir traços estilísticos do texto ou do escritor estrangeiro e de questionar qualquer uso linguístico que possa interferir na aparentemente imperturbável comunicação da intenção do autor estrangeiro [...]. Quanto mais fluente a tradução, mais invisível o tradutor e, presumivelmente, mais visível o autor ou o significado do texto estrangeiro. $^{92}$

Se, por um lado, Venuti atribui ao leitor de traduções uma certa responsabilidade pela invisibilidade do tradutor por voltar a sua atenção única e

\footnotetext{
${ }^{91}$ Segundo definição constante do site do Senado Federal, chama-se "redação do vencido" a "redação do texto de uma proposição aprovada em primeiro turno sob a forma de substitutivo, ou seja, com emendas que alteram o conteúdo da proposta original. Encerrada a primeira votação, a proposição e suas respectivas emendas são encaminhadas à comissão competente para a redação do vencido, isto é, a elaboração do novo texto - já incluindo as alterações feitas - para ser submetido ao segundo turno de votação, chamado turno suplementar”. Disponível em $<$ https://www12.senado.leg.br/noticias/glossario-legislativo/redacao-do-vencido> . Acesso em $18 / 12 / 2019$.

${ }^{92}[\ldots .$.$] the general tendency to read translations mainly for meaning, to reduce the stylistic features$ of the translation to the foreign text or writer, and to question any language use that might interfere with the seemingly untroubled communication of the foreign writer's intention. [...] The more fluent the translation, the more invisible the translator, and, presumably, the more visible the writer or meaning of the foreign text.
} 
exclusivamente para o enredo de uma obra de ficção, por exemplo, em detrimento do trabalho textual elaborado pelo tradutor, por outro, a tradutora Raquel Zampil (2018) relatou estar experimentando uma aproximação com o leitor, aproximação esta cada vez maior e que só vem sendo possível graças às redes sociais. Tradutora dos três últimos livros da série Percy Jackson, lançada pelo selo Galera, do Grupo Editorial Record, Zampil informou que recebeu inúmeras mensagens de fás da série, que, após verem seu nome na ficha catalográfica, entraram em contato com ela via mensagem eletrônica. Pelo menos em tese, esse insight de procurar na ficha catalográfica o nome do tradutor de uma obra com a intenção de fazer contato demonstra, na minha opinião, o quanto o público leitor brasileiro do século XXI, mesmo (ou talvez sobretudo) a camada mais jovem, está atento ao fato de que aquela obra que tanto vem aguçando o seu interesse passou pelas mãos de um tradutor. Em suma, o leitor brasileiro, na contemporaneidade, tem consciência de que aquela obra é, sim, uma obra estrangeira, como indicam os sites das editoras e das livrarias, mas que foi traduzida para a sua língua materna. O caso narrado por Zampil, pelo menos a priori, demonstra que o tradutor de obras literárias no Brasil não está tão invisível como afirmam muitos teóricos do campo dos Estudos da Tradução.

Outro assunto pertinente à figura do tradutor é a presença - ou a ausência de paratextos editoriais escritos por esse profissional, que executa a atividade central do processo aqui em tela. Identificar numa obra traduzida a inclusão de um prefácio escrito pelo tradutor, por exemplo, seria constatar materialmente a presença do profissional que possibilitou a leitura daquela obra pelo público leitor da cultura tradutora. O termo "paratexto" - e outros identificadores de uma subdivisão, como “epitexto” e "peritexto” - foi cunhado pelo crítico literário francês Gerard Genette, que o define como:

o reforço e o acompanhamento [de um texto] [...] como um nome de autor, um título, um prefácio, ilustrações [...] que [...] o cercam e o prolongam exatamente para torná-lo presente, para garantir sua presença no mundo, sua “recepção” e seu consumo. [...] [O] paratexto é aquilo por meio de que um texto se torna livro e se propõe como tal a seus leitores, [...], ao público. (GENETTE, 2009, p. 9)

Com referência à presença de paratextos de autoria do tradutor, um exemplo interessante é o do prefácio ao romance Mary Barton, de Elizabeth 
Gaskell (1810-1865), escrito pela tradutora da obra, Julia Romeu. Por sugestão da própria Romeu, que alegou ser o romance de Gaskell rico em dados históricos da época que lhe serve de pano de fundo, a Record decidiu publicar o prefácio escrito por ela a fim de ambientar o leitor brasileiro na Manchester de meados do século XIX. No entanto, mesmo tendo cumprido a função de apresentar a obra por intermédio de um prefácio, fornecendo ao leitor o contexto histórico ali representado, a tradutora poderia ter aproveitado o espaço concedido pela Record para direcionar um pouco de luz para o seu próprio trabalho, comentando as dificuldades, os nós tradutórios, enfim, mostrar ao leitor da obra traduzida o caminho que ela, tradutora, precisou trilhar para que aquele texto em português se materializasse. Ao omitir o trabalho da tradução, entende-se que Romeu, ainda que não intencionalmente, contribuiu para que a figura do tradutor e a tradução permanecessem invisíveis. Desse modo, a tradutora acabou por privilegiar o trabalho autoral em detrimento do trabalho tradutório. Essa assimetria valorativa, por assim dizer, em relação à chamada obra original e à tradução, também se denuncia na forma como Romeu assinou seu prefácio ao romance Mary Barton. Considerando que Julia Romeu, como informa o site da editora Companhia das Letras $^{93}$, atua como tradutora literária há mais de dez anos e possui no seu currículo a coautoria de três musicais que assina com a mãe, a escritora Heloísa Seixas, infere-se que Romeu conta com um repertório de traduções muitíssimo mais numeroso do que os três musicais dos quais é coautora. No entanto, ao assinar o prefácio supracitado, Romeu se autointitula primeiramente como escritora e, em segundo lugar, como tradutora ${ }^{94}$.

A opção de Julia Romeu pela ordem das profissões que exerce nos remete ao poeta inglês S.T. Coleridge (1772-1834) que, em sua Bibliographia Literaria (1817), fala dos conceitos de Fancy e Imagination. Segundo Coleridge, Imagination [seria] o supremo e orgânico poder criativo em oposição ao inerte mecanismo de Fancy"95 (BASSNETT, 2014, p. 73). Ao se identificar primeiro como escritora e, em segundo plano, como tradutora, Romeu parece ter endossado

\footnotetext{
93 Disponível em: <www.companhiadasletras.com.br/autor.php?codigo=02815>. Acesso em 10/11/2017.

${ }^{94}$ Ver ANEXO A.

${ }^{95}$ Imagination [would be] the supreme creative and organic power, as opposed to the lifeless mechanism of Fancy.
} 
as ideias de "superioridade" do "supremo e orgânico poder criativo" ("Imagination" = obra autoral) e de "inferioridade" do "inerte mecanismo" ("Fancy” = tradução). Essa desproporção considerável entre o valor da obra autoral e o valor da tradução é ratificada pelo depoimento de Renata Pettengill quanto a paratextos assinados pelo tradutor, que considera uma exceção à regra:

Talvez um texto de orelha ou algo assim, mas só em casos especiais, em que a tradução tem valor igual ou quase igual ao do texto do autor, ou quando há influência do tradutor, ou quando a escolha daquele tradutor vai ser determinante para que as pessoas queiram ler o livro não só por causa do autor, mas também por causa do tradutor. (PETTENGILL, 2018, p. 166)

Outro exemplo citado por Silvia Leitão parece evidenciar a(s) dicotomia(s) “obra autoral x obra traduzida” e "autor x tradutor”. Ao ser indagada se a Record, como um todo e não somente os selos editoriais por que respondeu na condição de editora do grupo, imprimia o nome do tradutor na capa de uma obra traduzida, Leitão respondeu que:

no passado, era muito comum [...] ter escritores consagrados fazendo tradução; se você consegue juntar no mesmo livro o peso do autor e o peso do tradutor, aí os dois nomes vão para a capa: "Herman Hesse com tradução de Lya Luft”, "Emily Brontë com tradução de Raquel de Queiroz". Sem dúvida, soma muito. (LEITÃO, 2018, p. 183)

A exemplo de Julia Romeu, que primeiro se identificou como escritora e, depois, como tradutora a despeito de seu consolidado repertório de traduções, a afirmação de Leitão vem corroborar o peso considerável conferido ao trabalho autoral. Afinal, o fiel da balança para a decisão de "ir para a capa” foi, antes de mais nada, o fato de Lya Luft e Raquel de Queiroz serem escritoras consagradas, que ocupam um lugar de destaque no sistema literário da cultura tradutora e que, circunstancialmente, estavam exercendo a função de tradutoras. O que não se pretende aqui é equiparar obra autoral e tradução, visto que são empreendimentos laborais distintos, com características peculiares. Seria prudente retomar aqui o que disse Teresa Dias Carneiro quanto ao "talento autoral” que as editoras buscam no tradutor. Entende-se que esse conceito de talento seja, na verdade, uma habilidade redacional, ou seja, a capacidade que se deseja que o tradutor tenha em aliar tradução e produção textual. Conforme alega Gouanvic (2005), não há uma hierarquia em que o trabalho autoral ocupa uma posição superior em relação à 
tradução e, sim, uma relação horizontalizada em que há apenas a questão cronológica, ou seja, para que a tradução se perfaça, é condição sine qua non que o trabalho autoral tenha sido feito primeiro. O que urge é mostrar essa relação horizontalizada, revelando as dificuldades enfrentadas pelo tradutor durante a tarefa de recriar o texto de origem na língua e cultura de chegada. É nessa habilidade de recriação tão peculiar que reside o valor do tradutor. Segundo Gouanvic (2005, p. 158) o habitus do escritor difere do habitus do tradutor, e não há que se confundir as duas atividades, apesar de, muitas vezes, a área de contato entre as duas se mostrar indistinta. Para o teórico, “o tradutor se torna agente do autor, ao transferir o discurso do autor para a cultura meta”96, ou seja, ao reelaborar o texto original na língua meta, o tradutor passa a atuar como um “procurador” do autor, uma vez que se torna, ainda que imperceptivelmente, seu representante na cultura de chegada.

Desse modo, o exemplo do prefácio da tradutora Julia Romeu ao romance Mary Barton e os relatos de Pettengill e Leitão a respeito da baixa ocorrência de paratextos de autoria do tradutor parecem evidenciar o quanto a atividade tradutória e a figura do tradutor são desprestigiados até por quem deveria lutar por reconhecimento: o próprio tradutor. Assim como muitos profissionais da área, Julia Romeu atribuiu um peso expressivo ao trabalho autoral, deixando de considerar o quanto é árdua a tarefa de recriar, transmutar ou ainda "transcriar", como propuseram os irmãos Campos, uma obra escrita numa língua e cultura diferentes da que a está recebendo. Obter da casa editorial a autorização para escrever o prefácio a uma tradução sua sem sequer incluir no texto a palavra “tradução” foi abdicar da oportunidade de mostrar ao leitor os bastidores da confecção daquele texto traduzido; foi colaborar para que se mantenham nas estantes das livrarias as placas indicativas onde se lê "literatura estrangeira" em vez de "literatura traduzida".

Ainda no tocante à utilização de paratextos como instrumento para dar visibilidade ao tradutor, Marcos Marcionilo fala sobre "traços" que o tradutor pode deixar na obra traduzida, traços estes que podem revelar pelo menos algo do perfil desse agente. Ao traduzir um texto, o tradutor imprime suas digitais

\footnotetext{
${ }^{96}[\mathrm{t}]$ he translator becomes the agent of the writer, transferring the writer's discourse into the target culture.
} 
linguísticas, principalmente através de suas escolhas lexicais e da forma como decide fazer as construções sintáticas. Essas marcas de natureza linguística, por assim dizer, Marcionilo denomina “implícitas”, pois encontram-se subjacentes à sua escrita, ou no caso do tradutor, à sua reescrita. Os paratextos de autoria do tradutor, por sua vez, são textos complementares ao principal em que o tradutor poderá falar da obra em si, do autor e, o que seria ideal, mas que raramente acontece, falar sobre o processo que resultou naquela tradução se deu. Se, por um lado, na condição de tradutor, Marcionilo se mostra favorável ao uso de paratextos de autoria do tradutor, por outro, já na posição de editor, ele se confessa cauteloso, pois esse espaço, que o tradutor poderia utilizar para falar de seu ofício, muitas vezes pode servir de "campo aberto de litígio entre as esferas da autoria e da tradução” (MARCIONILO, 2016). Como exemplo, o editor cita a versão traduzida do Evangelho de Lucas na tradução ecumênica da Bíblia ${ }^{97}$, em que o tradutor, um padre ferrenho opositor da tradução ecumênica ${ }^{98}$, se valeu de uma nota do tradutor para tecer duras críticas a essa vertente da tradução dos textos sagrados. Dentre os paratextos que podem dar visibilidade ao tradutor mais imediatamente, pelo menos do ponto de vista visual, é, sem dúvida, a capa. Sobre esse quesito, Marcionilo afirma que a Parábola Editorial traz "para a capa o nome dos tradutores, numa demonstração de que a tradução é por nós qualificada como coautoria a título pleno” (MARCIONILO, 2016; grifo meu). O editor da Parábola Editorial acrescenta ainda que

[e]ssa é uma regra que deveria ser aplicada por todo o mercado editorial, que ainda comete o erro grosseiro de fazer divulgação de obras traduzidas sem fazer constar o crédito da tradução, ou que registra esse mesmo crédito pelo menos no frontispício de cada obra, escondendo-o na página de créditos e na ficha catalográfica. (MARCIONILO, 2016)

\footnotetext{
${ }^{97}$ Vale lembrar que a Parábola Editorial não publica obras literárias, apenas acadêmicas, na área de linguística e de literatura.

${ }^{98}$ A tradução ecumênica da bíblia é um projeto que teve início no ano de 1963 graças à iniciativa do grupo formado por padres dominicanos, então responsáveis pela Bíblia de Jerusalém. Desejosos de fazer uma revisão no texto, convidaram especialistas de orientação protestante para integrarem o grupo de trabalho, o que resultou no que veio a se chamar "tradução ecumênica". Posteriormente, aos exegetas católicos apostólicos-romanos e aos protestantes, somaram-se católicos ortodoxos. (Fonte: www.abiblia.org/ver.php?id=334).
} 
No entanto, se se examinar a edição brasileira da obra Tradução: história, teorias e métodos ${ }^{99}$, publicada pela Parábola Editorial e traduzida pelo próprio Marcionilo, constata-se que o que editor defendeu durante a entrevista não se verificou no título citado. O editor Marcos Marcionilo deixou passar despercebida a omissão do nome do Marcos Marcionilo tradutor na capa da obra publicada pela editora em que também atua como editor e da qual é sócio. Ainda que inadvertidamente, a Parábola Editorial cometeu o "erro grosseiro" de não dar os devidos créditos ao tradutor Marcos Marcionilo no “fronstispício” da obra mencionada, "escondendo-o na página de créditos e na ficha catalográfica”.

Este capítulo foi dedicado ao que denominei “fase 1" da produção do texto traduzido, abordando o papel do tradutor, agente da tarefa que considero central no processo aqui em exame. No próximo, serão focalizados os profissionais a quem se confia o aperfeiçoamento do texto entregue pelo tradutor, atividade esta designada aqui como a "fase 2" da produção textual, escrutínio inescapável quando se trata de indústria livreira.

${ }^{99}$ Ver ANEXOS B, C e D. 


\section{A produção (fase 2): copidesques (preparadores de originais), revisores, designers de capa e outros agentes}

Muito provavelmente por ser uma atividade produtiva no seu sentido mais estrito, ou seja, uma atividade que tem por propósito a produção, a tessitura de um texto, é inviável para o tradutor revisar o que elabora ao longo da tradução. Afinal, no briefing que lhe foi entregue pela editora contratante, há um fator de suma importância que o profissional precisa ter sempre em mente: prazo. É em função dessa data limite que vão se desenrolar as etapas que sucedem a tradução. Dessa forma, é muito pouco provável que o tradutor consiga elaborar um texto irrepreensível, cuja leitura transcorra sem qualquer sobressalto, como o querem as editoras brasileiras, de um modo geral. O tradutor capaz desse feito, como disse Pettengill, é o desejado pelo Grupo Editorial Record, pois envia um texto tão bem escrito em português que não fica retido muito tempo no copidesque e na revisão. No entanto, advertiu a editora, por mais experiente que seja o tradutor, por melhor que seja o texto que ele produza, as etapas de revisão são inescapáveis, e alterações de toda ordem são feitas invariavelmente. Em suma, para que o texto traduzido atenda aos requisitos de qualidade de quem o encomendou, é necessário que se faça, ao menos, uma leitura para que o leitor de olhos treinados, o copidesque, em maior grau, e o revisor, em menor, possam detectar obstáculos que se impuserem a uma leitura que precisa ser feita sem entraves. Como observado, no Grupo Editorial Record, o texto estrangeiro, depois de traduzido, passa por uma primeira revisão que lá é denominada copidesque. É esse profissional, o copy, que faz o cotejo entre original e tradução, lendo linha a linha, para verificar se o que está dito no texto de partida está dito também no de chegada. Findo o trabalho de copidesque, o texto traduzido, e agora copidescado, retorna à editoria, para que se confira se as emendas (marcações) feitas pelo profissional foram pertinentes. Emendas checadas, o texto segue para uma segunda revisão, esta denominada propriamente de “revisão" dentro do organograma da empresa. Pettengill (2018) esclarece que não cabe ao profissional responsável por essa segunda revisão a checagem da tradução, tarefa exclusiva do 
copy. É da alçada do revisor verificar eventuais erros de pontuação, ortografia e, muito raramente, o emprego inapropriado de uma palavra, mas nunca a checagem da tradução propriamente dita. Tanto assim o é que o revisor não lê o texto na íntegra, atendo-se apenas às emendas feitas pelo copy. Alegou a editora que, essa divisão clara de competências garantirá não só um bom texto em português, mas também a agilidade do processo de lapidação textual. Como definiu a própria editora, essa segunda revisão é o "pente fino” por que passam as traduções publicadas pelo grupo. Ela destacou ainda que, quando se trata de tradutores novatos, inexperientes, os editores recomendam aos revisores que redobrem a atenção.

Da mesma forma como ocorre com os tradutores, no Grupo Editorial Record, os revisores também formam uma equipe fixa e integram o quadro de “colaboradores externos” da editora. Visto que nem tradutores e nem revisores possuem vínculo empregatício com a empresa, trabalhando, portanto, por contrato a cada obra encomendada, o termo “colaborador externo”, ao que parece, é uma outra denominação para freelancer. Levando-se em conta que tradutor e revisor são os dois agentes da cadeia editorial que têm por funções, respectivamente, a tessitura e o escrutínio do texto traduzido, seria de se esperar que houvesse uma ação coordenada entre esses profissionais, assim como propõe Alasdair MacIntyre (ver Capítulo 1, seção 1.6), com o intuito de confeccionar um produto de alta qualidade. Entretanto, segundo Pettengill (2018) e Leitão (2018), não há um contato direto entre esses dois agentes que, de certa forma, partilham do mesmo objeto de trabalho: o texto traduzido. Concluída a tradução, o tradutor envia o texto ao editor, que encaminha para o profissional encarregado do copy. Segundo Leitão, "é de bom tom" devolver ao tradutor o texto para que ele veja as modificações feitas pelo profissional do copidesque. Mesmo não sendo de praxe na Record, conclui-se que, quando esse retorno ocorre, outorga-se ao tradutor uma posição hierárquica de prestígio, pois concede-se a ele o poder de reverter qualquer emenda feita pelo copy, se assim o julgar prudente. Renata Pettengill relatou que também costuma retornar a tradução ao tradutor depois de o texto passar pelo copidesque. No entanto, esclareceu ela, dependendo de quem seja o tradutor, esse retorno terá propósitos diferentes. No caso dos “medalhões”, dos “tradutores de pedigree”, como denominou a própria editora, esse retorno ocorre 
para que o tradutor, detentor de considerável capital simbólico e, portanto, em posição hierárquica superior à do copidesque, avalize ou não as alterações feitas em sua reescrita tradutória. No caso de tradutores menos experientes, esse retorno tem propósito pedagógico, para que o profissional saiba que aspectos do seu trabalho precisam ser melhorados (PETTENGILL, 2018). Do ponto de vista organizacional, pelo que se depreendeu dos depoimentos de Pettengill e Leitão, o tradutor parece ocupar, ainda que tacitamente, uma posição hierárquica privilegiada na cadeia editorial, não só por caber a ele a tarefa central do processo aqui pesquisado, mas também por possuir um capital simbólico específico que é decorrente de sua habilidade tradutória, dentre outros fatores.

Como informaram as participantes da pesquisa, é diversificada a nomenclatura empregada no campo editorial para se referir ao que tradicional e comumente se chama "revisor”. “Copidesque”, "preparador de originais” e o usual "revisor” são termos que designam o profissional a quem caberá a tarefa de ler o texto traduzido e, em função das normas editoriais e do seu feeling de leitor especializado, proceder às modificações que se fizerem necessárias para que, a posteriori, o texto traduzido seja lido sem entraves pelo leitor comum. Parece ser legítimo afirmar, então, que o revisor, não importando como seja nominado, atuará como o primeiro termômetro da recepção daquela tradução pelo público leitor da comunidade linguística a que se destina. Cada alteração textual que vier a fazer terá por objetivo atingir a fluência de leitura almejada pela casa editorial contratante, ou seja, pelo agente de patronagem promotor da cadeia editorial em questão.

Em seu artigo “A (não) relação entre tradutores e copidesques no processo de edição de obra estrangeira”, Flávia Carneiro Anderson (2015) faz uma detalhada análise dessa "lacuna relacional”, por assim dizer, ou como ela mesma chama essa “(não) relação entre tradutores e copidesques”. Anderson abre seu texto com uma epígrafe contendo a opinião da tradutora Regina Motta de que a natureza do trabalho do revisor reside na neutralidade. Como se vê pelo depoimento em destaque, é cobrada do revisor uma imparcialidade ainda maior do que a imposta ao tradutor em relação ao autor. Note-se que quem identifica essa neutralidade como inerente ao trabalho do revisor é uma tradutora, cuja atividade é marcada pela mesma cobrança de isenção. No âmbito teórico, argumenta-se que 
essa "neutralidade” é a grande responsável pela “invisibilidade do tradutor”, tema desenvolvido por Venuti nos Estudos da Tradução e já discutido anteriormente. Desse modo, como propõe o próprio teórico norte-americano, em não permitindo que o seu trabalho se manifeste aos olhos do leitor da cultura receptora, o tradutor acaba por se confinar nos bastidores da cadeia editorial. Como se percebe, a invisibilidade é ainda mais acentuada quando se trata do copidesque, cujo nome quase sempre é omitido da ficha catalográfica, embora seja informado na página de expediente. Na hipótese de se desenvolver aqui uma relação entre tradutor, copidesque e revisor, tomando por base o fator "invisibilidade", teremos a seguinte expressão:

INVISIBILIDADE DO REVISOR > INVISIBILIDADE DO COPIDESQUE > INVISIBILIDADE DO TRADUTOR

Desse modo, à medida que o texto segue o seu fluxo na cadeia editorial, maior será a invisibilidade do agente que dele se ocupa: a invisibilidade do revisor, via de regra algum funcionário da editora, é maior do que a do copidesque (cujo nome dificilmente consta da ficha catalográfica), que ainda é mais invisível do que o tradutor (a quem sempre se dão os créditos da tradução).

Admitindo uma considerável diversidade terminológica ${ }^{100}$ para designar a função de revisor em voga no campo editorial, Anderson (2015, p. 39) adota, para fins do estudo que se propõe aqui, as definições que se discutirão a seguir:

- o profissional que realiza a atividade de copidesque e que, por um processo metonímico, recebe a mesma denominação, é quem faz o cotejo entre original e tradução; a finalidade desse cotejamento é "verificar eventuais erros de interpretação, redação, saltos etc”; além disso, cabe ao copidesque observar se o estilo do texto de partida foi preservado durante a tradução e se o produto final foi elaborado de forma consistente;

- o revisor, por sua vez, não tendo acesso ao texto fonte, possui como campo de observação apenas o texto traduzido; assim, cabe a ele "verifica[r] se o tradutor conseguiu adequá-1[o] satisfatoriamente à língua meta e [corrigir] eventuais deslizes gramaticais” (p. 39);

\footnotetext{
100 A terminologia apresentada aqui é a adotada por Anderson (2015), porém é sabido que há outras em que figuram outros termos. Dentre esses, por exemplo, encontram-se os que designam o que genericamente se denomina "revisor". Machado (2018, p. 39), por exemplo, refere-se à tarefa do "copidesque" como "leitura ou revisão comparada (também chamada de cotejo ou cotejamento).
} 
- o revisor técnico, como o próprio termo já sugere, atua em casos de tradução de textos técnicos e tem por função avaliar sob a ótica de sua expertise, "a pertinência e [a] adequação dos termos e conceitos técnicos" (p. 39);

- o termo "preparador", que em algumas casas editoriais ganha o complemento “de originais”, é, na nomenclatura adotada por Anderson (2015), o agente da cadeia editorial que se ocupa tão-somente do aspecto gráfico do texto; em algumas editoras, porém, como informa a autora, o termo "preparador [de originais]" equivale ao que ela designa por “copidesque”.

Sobre as definições de Anderson, cabem aqui algumas considerações. No tocante à figura do copidesque, é ele o agente da segunda fase da produção que está credenciado pela casa editorial a modificar a tradução sempre que julgar necessário. O verbo “julgar”, aqui, tem duplo significado: “entender” e “decidir”. É se valendo deste último que o copidesque julga o que o tradutor fez e retifica as inadequações por ele detectadas. Pelo que se pode inferir, portanto, é exigido também do copidesque, se não um conhecimento acadêmico de literatura e de produção textual, pelo menos um senso apurado do que seria um bom texto traduzido, além da habilidade tradutória que o credencia a modificar as escolhas do tradutor. De acordo com a conceituação de Anderson, é cobrado, inclusive, que o profissional de copidesque identifique o estilo literário do autor/texto e verifique se o tradutor o preservou durante a tradução. Enfim, pela definição da autora do artigo, ao profissional de copidesque, pelo menos na prática, é conferida uma espécie de poder deliberativo sobre o trabalho do tradutor. A ementa do curso oferecido pelo NESPE (Núcleo e Estratégias e Políticas Editoriais) ${ }^{101}$ parece comprovar a necessidade de o copidesque possuir as competências anteriormente descritas. Intitulado "Preparação de textos traduzidos”, o curso oferece, dentre outros itens, "estilo do autor vs. idioma de origem" e "gêneros peculiares: poesia, teatro”. Assim sendo, detentor de conhecimento e treinamento específicos, o copidesque, estará apto a promover as intervenções necessárias para a obtenção do texto traduzido que a indústria editorial almeja. O trabalho do copidesque, pelo que se pode inferir, funciona como um indicador de qualidade do trabalho do

\footnotetext{
${ }^{101}$ Disponível em: $<$ http://nespe.com.br/curso-preparacao-e-revisao-de-textos/>. Acesso em $15 / 07 / 2020$
} 
tradutor. No caso dos tradutores sem chancela, ou seja, com pouco (ou nenhum) capital simbólico, a quem raramente se devolve a tradução depois de examinada pelo copidesque, é a versão desse profissional que prevalece, indo, assim, ao prelo. No entanto, sendo o nome do tradutor que consta da ficha catalográfica, no caso de uma revisão benfeita de uma tradução sem a mesma qualidade, é ao tradutor que se atribuirá aquele texto "bem traduzido". O inverso, no entanto, também se verifica: no caso de um copidesque malfeito, recairão sobre os ombros do tradutor os "pecados" cometidos pelo outro profissional. O revisor, por sua vez, da forma como o conceitua Anderson, parece nos remeter aos estudos descritivos de Toury, que têm por premissa a ideia de que a tradução é um produto da cultura receptora e que recorrer à cultura fonte nem sempre é uma necessidade imperiosa. Seria o revisor, então, a segunda triagem, ou melhor, seria ele o agente da cadeia a ter antecipadamente a experiência que o leitor comum virá a ter depois que todo o processo aqui investigado chegar ao fim. O revisor técnico, por seu turno, a exemplo do tradutor técnico, precisa aliar o conhecimento técnico relativo ao tema sobre o qual versa o texto estrangeiro a ser traduzido e a habilidade tradutória propriamente dita. Por fim, o preparador (de originais) tendo como função a revisão do aspecto gráfico do livro, pelo relato de Anderson (2015), parece ser pertinente a algumas editoras, que não é o caso do Grupo Editorial Record, cujo modus operandi tem sido objeto de maior escrutínio no presente trabalho.

Num texto bem-humorado, datado de janeiro de 2011 e disponível no blog da editora Companhia das Letras ${ }^{102}$, a jornalista e tradutora Vanessa Barbara traça um perfil do copidesque, a quem chama de "preparador”103. Já no título, “O preparador, esse desconhecido”, a autora já denuncia a invisibilidade desse agente da segunda fase do estágio da produção. Segundo Barbara, “um bom preparador é caso psiquiátrico", uma vez que, para executar sua tarefa do modo mais satisfatório possível, ele(a) precisa “sofr[er] de um leve transtorno obsessivo-

\footnotetext{
${ }^{102}$ Disponível em: <http://www.blogdacompanhia.com.br/2011/01/o-preparador-essedesconhecido $>$. Acesso em 15/01/2018.

${ }^{103}$ A denominação dessas etapas de revisão, lato sensu, é muito flutuante, pelo que pude apurar durante a pesquisa, variando de editora para editora. Algumas casas editoriais, como Vanessa Barbara informa em seu artigo, designam o copidesque, ou seja, o primeiro "revisor" do texto, o que faz o cotejo entre texto estrangeiro e texto traduzido, como "preparador de originais".
} 
compulsivo e se[r] persistente, perfeccionista e incansável”, pois deverá ter o instinto de pesquisador e sair em busca de filigranas, seja a composição química de uma substância ou o nome da peça íntima que costumava vestir uma personagem histórica, exemplos citados por Barbara. Ainda delineando o perfil do preparador, Vanessa Barbara menciona Paulo Werneck, ex-editor da Companhia das Letras, que dizia que a palavra que define um bom profissional da revisão é “desconfiança”. Ao suspeitar de tudo, o preparador parte em busca de informações e, obcecado por desvelar o desconhecido, acaba por contribuir enormemente para a perfeição do produto final, seja um livro nacional ou uma tradução. Comentário semelhante fez Pettengill, mas em referência ao tradutor ideal. Dotado dessa mesma obsessão pela pesquisa e pela fluência do texto traduzido, o tradutor ideal enviará à editoria um texto sem arestas, cuja leitura transcorrerá sem sobressaltos nas etapas do copidesque e da revisão.

Além de traçar um perfil do preparador, Barbara fala sobre a atividade da preparação de originais em si. A tradutora diz que, nas casas editoriais de um modo geral, o preparador é o agente que realiza a primeira revisão de um livro, ainda em arquivo Word. Segundo ela, por ser a primeira filtragem, a preparação de originais é a mais trabalhosa, pois tem por objetivo limpar o texto, eliminando imperfeições e, com isso, acaba por aperfeiçoá-lo. Barbara prossegue na descrição da atividade, definindo-a como "uma leitura, escorada por vasto material de apoio e dicionários vernáculos [e estrangeiros]” (BARBARA, 2011). Durante essa leitura escrutinadora, por assim dizer, o preparador observará com toda a atenção detalhes referentes a sintaxe, coerência, ortografia, ambiguidade, repetição desnecessária, vícios de linguagem e “ecos de língua estrangeira”. Este último fator, como enumera Barbara, consiste em falsos cognatos, ritmos frasais e outras questões de natureza literária. Eliminados esses traços da língua de partida, “o texto [...] fluir[á] bem, sem engasgos” (BARBARA, 2011). A avaliação de Barbara corrobora o que revelaram Leitão e Pettengill: a fim de se obter um texto traduzido "de forma fluente", é necessário reescrevê-lo conforme as normas da cultura tradutora. Com base nesses depoimentos, parece legítimo afirmar que a fluência de que falam Pettengill, Leitão e Barbara consiste em imprimir no texto traduzido as normas textuais da cultura receptora que resultarão num texto redigido conforme a sintaxe e o léxico da língua de chegada. Vale ressaltar, mais 
uma vez, que, conforme o relato de Barbara, é exigida do copidesque uma expertise tradutória, conhecimento este que avalizará o seu poder de decisão sobre as escolhas do tradutor, considerando aqui o tradutor comum e não o tradutor “com pedigree”, como denominou Pettengill durante a entrevista.

Por sua vez, Anastácia Cabo (2018), responsável pelo blog Notas Literárias, observou que muitos blogueiros que dedicam suas páginas à literatura não têm conhecimento de como se processa a produção textual no mercado de livros. A maioria, segundo ela, atém-se às informações contidas na ficha catalográfica e, no caso de uma obra traduzida cujo texto contenha inadequações, quando observam esse aspecto, costumam atribuir a responsabilidade única e exclusivamente ao tradutor. Afinal, a editora dá o crédito apenas ao agente da tradução. Em virtude de sua atividade como editora pela The Gift Box Editora, Cabo costuma atribuir ao preparador de originais e não necessariamente ao tradutor a responsabilidade por uma tradução malfeita que acaba indo ao prelo. Por atuar no campo editorial, ela está ciente de que há uma cadeia de atividades e que a preparação de originais (= copidesque) é o processo de refinamento por que o texto traduzido sempre passa. Dessa forma, é função do preparador de originais detectar e corrigir equívocos de tradução, aperfeiçoar construções sintáticas e checar vocabulário, por exemplo. O exemplo dado por Cabo ilustra bem a sua afirmação de que uma boa preparação de originais garante a fluidez do texto, característica do texto traduzido exigida pela maioria (se não pela totalidade) das editoras, como já mencionado. Segundo a blogueira/editora, é o preparador de originais que vai garantir uma boa recepção da tradução por parte do leitor da cultura alvo. É esse profissional que vai evitar que o leitor da cultura de chegada sinta estranheza ao ler, por exemplo, uma trama policial e se deparar com algo inusitado do tipo "pessoa de interesse”104. Somente no decorrer da leitura, estando atento ao texto e ao contexto, é que o leitor deduzirá que se trata de um “suspeito”, ou seja, “uma pessoa que seja de interesse da investigação”. É bem verdade que o tradutor teria que ter sido o primeiro a estranhar o termo no momento em que lesse o texto por ele próprio traduzido. Nesse caso, seria ele

\footnotetext{
${ }^{104}$ Person of interest: A person who is suspected by the police or other law enforcement agency of knowing about or committing a crime. Disponível em:

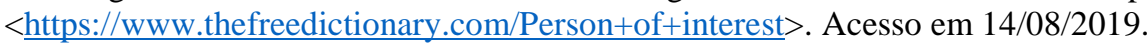


dotado não só do talento autoral de que falou Teresa Carneiro (2018), mas também, e sobretudo, do feeling de falante proficiente na língua de chegada para estar apto a descobrir que há “algo fora do lugar”, ou seja, “pessoa de interesse” é um termo que, pelo menos em um primeiro momento, parece não pertencer à língua da tradução. Deveria ter entrado em cena aí a porção pesquisadora do tradutor que, num rápido acesso a um dicionário online, teria descoberto se tratar de “suspeito". Se tempo tivesse, ainda poderia tentar verificar se, no jargão policial local, o termo é usado. Como alertou Cabo, porém, muitas vezes, o trabalho laboral da tradução envolve o tradutor de tal forma que estranhezas no âmbito vocabular podem passar despercebidas, deixando marcas da língua estrangeira no texto traduzido. Além disso, o tradutor executa a sua tarefa sob a pressão do prazo e, com isso, a prioridade passa a ser a completude do serviço. Afinal, o tradutor sabe que o texto traduzido passará por uma rigorosa revisão, executada por outros agentes, de quem a editora também exige competência tradutória, e cuja função na cadeia editorial é justamente a de aprimorar a tradução.

Em entrevista concedida em julho de 2019, o copidesque Rodrigo Austregésilo, que, no mercado editorial, assina como Daniel Austie, abordou alguns pontos importantes relativos à sua função de agente da fase aqui em foco. Apesar da formação em Publicidade, a experiência profissional de Austregésilo se circunscreve ao mercado editorial, estando ele, atualmente, acumulando as funções de profissional de marketing numa editora baseada no Rio de Janeiro e a de copidesque, como freelancer, para outras casas editoriais, dentre elas o Grupo Editorial Record. Conforme relatou, Austregésilo aprendeu empiricamente a desempenhar seu ofício de profissional sem ter sido submetido a qualquer tipo de treinamento oferecido pelas editoras as quais presta serviço. Sobre as intervenções que faz com maior frequência nas traduções cujo copidesque lhe é confiado, Austregésilo afirmou que, no geral, o que ele identifica com maior regularidade é a necessidade de se transformar o texto "mais duro", o que vem do tradutor, num texto "mais fluido" (ou "mais fluente”). Quanto ao contato (ou a ausência dele) entre o tradutor e o revisor ao longo do processo de tradução e revisão de um texto estrangeiro, assunto exaustivamente analisado por Flavia Carneiro Anderson (2015), Austregésilo informou que foram raras as vezes em que, na condição de 
profissional de copidesque, sentiu a necessidade de estabelecer esse contato direto com o tradutor, dirimindo suas dúvidas diretamente com o editor. E acrescentou ainda que, de um modo geral, realiza o copidesque dos mesmos tradutores e, em razão disso, conhece as características da reescrita tradutória de cada um deles. Nessas oportunidades excepcionais, o canal só se deu mediante a anuência do editor em questão, que, segundo relatou, nunca se opôs a essa comunicação direta. Entretanto, na era digital, em que o serviço de copidesque é feito em arquivo Word e não mais em laudas impressas, a interação entre tradutor e copidesque pode se efetivar, ainda que de forma indireta, via editor, caso o texto retorne ao primeiro depois de efetuadas as alterações pelo segundo. As mensagens que vierem a ser trocadas entre esses dois agentes serão feitas pelos comentários ensejados pelo recurso de controle de alterações disponível no Word. Se esse retorno do texto ao tradutor não vier a ocorrer, pelo menos, estarão registradas no arquivo de texto as justificativas para algumas das escolhas e das alterações feitas, respectivamente, pelo tradutor e pelo copidesque.

Justamente a propósito dessa “(não) relação entre tradutor e revisor”, como grafa Anderson (2015), indaguei ao entrevistado se havia uma espécie de hierarquia dentro do campo editorial em que ao tradutor fosse conferido um status privilegiado em detrimento do revisor. Austregésilo respondeu que, de certa forma, o tradutor goza dessa posição mais privilegiada, sim, mas que isso seria justificável, segundo ele. Essa diferença entre “posições hierárquicas” se deveria mormente ao fato de que a tradução é uma autoria. Afinal, é o tradutor, e não o copidesque, que precisa assinar um termo de cessão de direitos autorais para a casa editorial. Esse status de autor é alcançado pelo tradutor, argumenta o copidesque entrevistado, porque é o tradutor que precisa "mergulhar naquele universo, especialmente na ficção” (AUSTREGÉSILO, 2019). Em razão dessa imersão total no texto fonte, segundo ele, é o tradutor que conhece com maior profundidade cada aspecto daquele microcosmo ficcional, seja no eixo textual, linguístico, seja no eixo temático, para poder se habilitar a reescrever, recriar, reelaborar todo aquele universo com todos os elementos que o compõem. Por essa intimidade com a criação do autor, Austregésilo afirma que o tradutor é o elemento "mais sensível” da cadeia editorial formada com vistas à tradução de uma obra literária. Para que essa recriação se faça da maneira mais plena e 
satisfatória possível, o tradutor pesquisa vocabulário, pensa em soluções para tantos impasses textuais que se lhe interpuserem o caminho.

A figura do tradutor como "o elemento mais sensível da cadeia editorial” vai ao encontro do que disse a tradutora Raquel Zampil ao classificar o tradutor como o agente executor da leitura mais completa de uma obra estrangeira. Por conseguinte, a tradução é o resultado textual (output) dessa leitura (input). Zampil compara a sua posição de leitora comum, quando consome uma obra traduzida num momento de lazer, por exemplo, e a sua posição como leitora-tradutora. Para ela, o tradutor é o agente da interligação entre duas comunidades linguísticas diferentes, e sua atuação é fundamental nesse processo. O primeiro passo para que essa conexão se implemente é a leitura minuciosa e profissional feita pelo tradutor. Mesmo admitindo que ninguém pode avocar para si a "verdadeira” e “única” interpretação de um texto, a leitura do tradutor será especializada, guiada pela pesquisa.

Após examinar o aspecto estritamente textual que, nesta segunda fase da produção da obra traduzida, está representado pelo espectro da revisão, volta-se agora o foco para um componente estratégico na confecção do livro como produto comercial, a capa, que sempre mereceu atenção especial das casas editoriais. Em homenagem ao Dia do Vendedor de Livros, comemorado no dia 14 de março, Juliana D’Arêde (2018) publicou no site Vai Lendo ${ }^{105}$ matéria sobre a importância da figura do livreiro na hora de ajudar o leitor a identificar uma obra cujo título e/ou autor lhe escapa da lembrança. "É aquele livro de capa vermelha” e "Sabe me dizer qual é aquele livro que tem uma moça na capa?” são frases que, por serem comumente ouvidas por livreiros, foram utilizadas para abrir o texto. A capa, como se vê, funciona como uma “digital plástica” da obra literária. Quando se trata de um livro traduzido, então, a capa parece requerer atenção redobrada, pois as informações visuais contidas na versão estrangeira decerto também necessitam ser "traduzidas”, ou seja, a capa poderá vir a ser reformulada para que haja uma identificação cultural com o público leitor da cultura de chegada. Em tempos de internet, porém, advertem Pettengill (2018) e Leitão (2018), o leitor da era digital toma conhecimento antecipadamente da existência daquela obra e, na

\footnotetext{
${ }^{105}$ Disponível em: < https://www.vailendo.com.br/2018/03/14/profissao-livreiro-vendendo-livrose-sonhos/> Acesso em: 20/11/2018.
} 
hora de adquirir a versão traduzida, tem a capa como identidade primária da obra. Nos dias de hoje, esse é um fator muito importante e, por isso, é sempre levado em consideração pelos editores brasileiros. Mudanças no layout da capa só ocorrem quando se julgar que a capa da versão original não surtirá o efeito comercial desejado ou quando, por alguma razão, os direitos autorais para a reprodução da capa não são adquiridos pela editora brasileira. Mais uma vez, entra a figura do livreiro, cuja opinião poderá ser o fiel da balança na hora de a editora decidir entre elaborar uma nova capa para a tradução ou manter a que ilustra a versão de origem. Mais adiante, no próximo capítulo, comentar-se-á um exemplo que ilustra bem esse aspecto.

Para compreender melhor esse processo criativo, em novembro de 2018, foi realizada entrevista com a designer de capa Renata Vidal, que atua no campo editorial desde o início dos anos 2000. Durante o encontro, além de fornecer informações sobre sua formação acadêmica e sua experiência profissional, Vidal falou sobre alguns aspectos da produção da capa de uma obra, incluindo nesse rol as traduzidas. O primeiro ponto a ser esclarecido por ela foi o fato de que o designer de capa trabalha com bancos de imagens que são selecionadas para compor um layout condizente com o tema, com o gênero literário e, até mesmo, que seja a marca da obra de um autor. Segundo Vidal, são raros os designers de capa, também chamados de arte-finalistas, que fazem ilustrações. Quando do briefing consta a elaboração de uma ilustração sofisticada, com traços sofisticados, o editor terá que recorrer a um ilustrador, outro tipo de agente, este com a habilidade específica do desenho. Vidal alertou também para o fato de que, diferentemente do que se possa supor, a etapa de concepção da capa de um livro envolve, além do designer, outros agentes da cadeia editorial. Conforme relatou, para cada briefing recebido das editoras para as quais trabalha, ela faz, pelo menos, três layouts. No caso da Record, por exemplo, Vidal informou que, quase invariavelmente, o layout de sua predileção não coincide com o escolhido pela editora. Como se trata de um fator de ordem quase que preponderantemente comercial, é a opinião da equipe comercial e de marketing que acaba por prevalecer. Muitas vezes, quanto à capa, o voto de minerva é dado pelo próprio autor. É o caso da escritora norte-americana Danielle Steel, denominada como “a 
dama do romance»"106 pelo próprio Grupo Editorial Record, que faz questão de avaliar as capas de seus livros, publicados no Brasil pelo selo Record. As capas de seus romances só são confeccionadas após a aprovação da autora.

A fim de abordar a questão da representação da cultura estrangeria por meio da tradução, desta feita no campo imagético, mostrei as duas capas que revestem o romance Inferno ${ }^{107}$, de Patrícia Melo. A capa da versão brasileira, publicada pela Companhia das Letras, mostra a imagem aérea distorcida de uma favela; por sua vez, a capa da versão estrangeira, traduzida por Clifford E. Landers e lançada pela Bloomsbury Publishing, exibia um menino portando um armamento pesado. Ao observar as duas imagens, Vidal alegou que a capa da versão estrangeira dificilmente seria a opção de alguma editora brasileira. Em primeiro lugar, pelo fato de expor uma realidade incômoda, que o público brasileiro quer esquecer; em segundo, porque a legislação brasileira (Estatuto da Criança e do Adolescente) vedaria a utilização de uma imagem que ligasse um menor ao mundo do crime. De qualquer forma, é importante notar as duas diferentes representações da favela brasileira que as culturas envolvidas tentaram oferecer aos seus respectivos leitorados. Enquanto a brasileira, por intermédio da Companhia das Letras, tentou amenizar a realidade muito provavelmente descrita no livro com a imagem aérea e desfocada de uma favela localizada num morro, muito comum no estado do Rio de Janeiro, a britânica, tendo por representante a Bloomsbury Publishing, coloca como ícone da cultura traduzida um menor segurando um armamento pesado, sugerindo um possível vínculo com o tráfico.

Falar sobre a escolha da capa de uma obra, nacional ou traduzida, é falar de marketing editorial. Sobre isso, em entrevista concedida ao site Homo Literatus $^{108}$, Bruno Zolotar, diretor de marketing do Grupo Editorial Record, diz que uma das principais funções do setor pelo qual é responsável é “fazer o leitor julgar, sim, o livro pela capa. E mais: ficar seduzido a ponto de levá-lo para casa” (ZOLOTAR, 2014). Componente visual do produto "livro”, a capa, muitas vezes, será toda a campanha de divulgação que um livro terá. Em razão disso, o setor de

\footnotetext{
106 Disponível em: <http://www.record.com.br/livro_sinopse.asp?id_livro=22090>. Acesso em: 14/08/2019.

${ }^{107}$ Ver ANEXO E.

108 Disponível em www.homoliteratus.com/escrever-e-uma-parte-do-trabalho. Acesso em 08/09/2019
} 
marketing procura a todo custo fazer com que a capa escolhida capte o espírito da narrativa e tente "traduzir o que o livro é" (ZOLOTAR, 2014). No tocante às capas que embalam versões traduzidas de livros estrangeiros, Zolotar afirma que, geralmente, as editoras brasileiras optam por fazer uma capa diversa da original. Isso ocorre em razão de dois fatores: a necessidade de adaptação à cultura receptora e o alto custo dos direitos autorais para a reprodução da capa estrangeira. Segundo ele, vez por outra, as editoras brasileiras se deparam com capas que contêm elementos visuais que apontam para dados da cultura fonte que são desconhecidos do leitor brasileiro. Em casos como esse, a capa original não fornecerá ao leitor pistas do mote do livro, ou seja, a função referencial que a capa precisa desempenhar não se verificará. Quanto à questão dos direitos autorais sobre a capa, a exceção parece ser a literatura voltada para o público infantojuvenil, que, via internet, acompanha os lançamentos no exterior (ZOLOTAR, 2014). Desse modo, a capa do original é mantida independentemente do alto valor dos direitos autorais, pois a editora tem altas expectativas de vendas quando se trata desse nicho mercadológico. Um outro exemplo citado por Zolotar que ilustra a influência crucial da internet na tomada de decisões do mercado editorial foi o romance Fallen, de Lauren Kate. Em vez de traduzir o título original pelo óbvio "anjo caído”, a Record houve por bem manter o título original, visto que a identidade nominal da obra já havia sido absorvida pelo público alvo, já amplamente divulgada no meio digital.

Também de grande relevância mercadológica, o título, assim como a capa de obras traduzidas, compõe uma etapa da segunda fase da produção que merece atenção especial. Ambos os elementos - título e capa - são determinantes para a boa vendagem de uma obra, seja uma produção nacional ou uma produção estrangeira traduzida para o português do Brasil. O critério de escolha desses dois itens, que funcionam como um cartão de visitas do produto editorial, é baseado mormente no feeling do editor. Como informou Pettengill (2018, p. 167), um dado a se considerar é o feedback dos compradores das livrarias que, por sua vez, recebem informações dos livreiros, estes os agentes que “estão lá na ponta e [...] estão vendo o que está chamando a atenção das pessoas na loja”. Tomando por base os cenários observados pelos livreiros em contato com a editora, parece ser legítimo afirmar que é esse profissional que capta a resposta (ver este conceito no 
Capítulo 1) dessa clientela específica àquele título traduzido veiculado por aquela capa plasticamente sedutora.

Durante a entrevista, Renata Pettengill (2018) citou dois exemplos bastante ilustrativos de como o título e a capa podem alavancar ou comprometer as vendas de um romance. Segundo a editora, sua primeira opção é, pelo menos a princípio, a de manter o título traduzido o mais próximo possível do original. No entanto, se, do ponto de vista comercial, essa tradução que segue mais de perto o título original não funcionar na língua alvo, recorre-se a uma segunda alternativa, mais adaptada, que seja mais palatável ao público leitor brasileiro. O primeiro exemplo é o do romance da escritora alemã Nina George, cujo título original é Das lavendelzimmer, que, em português, significa “O quarto lavanda”. Já ao longo da tradução do alemão para o inglês ${ }^{109}$, houve uma mudança radical no título, pois não se preservou nenhum dos elementos constantes do título em alemão. Da imagem tão particular, tão privada que evoca o sintagma “o quarto lavanda”, partiu-se para um cenário mais amplo sugerido pelo título The Little Paris Bookshop. Conforme disse Pettengill, o título em inglês, em comparação com o austero e conciso original em alemão, tinha muito mais apelo comercial. Além disso, o enredo do romance, de fato, gira em torno de uma pequena livraria parisiense. No entanto, Pettengill sentia que, em português, ainda faltava alguma coisa. Entrou em cena, então, o seu feeling profissional, fator a que a própria editora havia se referido anteriormente. Foi nesse momento que, inspirada pelo próprio protagonista do romance, um livreiro que tem o dom de captar o problema por que passa o cliente e, a partir disso, recomendar o livro ideal para ajudá-lo a superar aquela dificuldade, Pettengill teve a ideia de substituir o adjetivo “pequena” (little) do título em inglês por “mágica”. Como alegou a editora, além de o título em português, a exemplo da versão em inglês, ter feito jus ao núcleo narrativo do romance, o fato de haver nele uma palavra que remeta ao fantástico, ao esotérico, mesmo que não se trate de algo do gênero, produz significativos efeitos no público leitor brasileiro. Pettengill alegou ainda que o leitor brasileiro de traduções se apega aos títulos do original e, quando há a necessidade de adaptálos, antes de decidir a forma final do título, as editoras recorrem não só ao

\footnotetext{
${ }^{109}$ Trata-se, portanto, de uma tradução indireta, pois o texto original foi escrito em alemão, depois traduzido para o inglês, que serviu de texto de partida para a tradução para o português.
} 
tradicional livreiro, mas também aos blogueiros das páginas literárias. São esses dois agentes que estão em contato direto com o consumidor de literatura traduzida.

Um outro exemplo comentado por Pettengill foi o da capa do romance de Keith Stuart, $O$ menino feito de blocos ${ }^{110}$. Segundo sua opinião, a capa da versão original, inglesa, composta de elementos visuais (blocos de encaixar - um elemento lúdico, portanto - sobre os quais parecem brincar duas figuras, uma representando um menino e a outra, um homem adulto) remetia ao público infanto-juvenil, enquanto que o público alvo do romance era, na verdade, o adulto. Partilhando da mesma opinião que Pettengill, o livreiro alertou que a capa, por estar aparentemente sugerindo o público alvo errado, poderia afetar negativamente as vendas. Atento ao prazo contratual que estava prestes a expirar, o diretor comercial da editora sugeriu que se pesquisassem as capas que aquele romance de Stuart havia recebido em outros países, e fez-se uma enquete entre os membros da equipe. A escolhida foi justamente a capa original, a que havia sido rejeitada por Pettengill e pelo livreiro. O argumento usado pelos que optaram pela capa original já foi referido aqui: com a internet, o leitor brasileiro, com frequência, tem acesso ao lançamento do original muito antes de os direitos autorais serem adquiridos pela editora brasileira. Desse modo, cria-se na mente do leitor uma identidade visual do produto veiculada pelo meio digital, e a capa é uma das referências mais marcantes na hora de se identificar uma obra.

O capítulo que ora finda teve por objetivo abordar os agentes responsáveis pela fase de produção e aperfeiçoamento textual, desempenhados respectivamente pelo tradutor e pelos profissionais da revisão, lato sensu, e também pelos profissionais das artes visuais que elaboram o invólucro que abriga o produto textual. No próximo, passarei a analisar como o produto final elaborado ao longo da etapa de produção, foco dos capítulos 3 e 4, chegará ao seu destino final, o leitor. Assim, observarei os agentes envolvidos no processo de distribuição, a sua atuação no comércio livreiro e, por fim, como a tradução é recebida pela cultura tradutora, voltando a minha atenção mormente às formas - profissional e leiga de crítica da tradução.

\footnotetext{
${ }^{110}$ Ver ANEXO F.
} 
5

\section{A pós-produção: distribuição, o papel das livrarias e dos livreiros, recepção em geral (resenhas, fortuna crítica) na chegada do livro traduzido aos leitores}

O quinto capítulo da minha tese tem por objetivo descrever e analisar o que, em sociologia da tradução, entende-se por recepção. Assim como já antecipado, nesta seção tento dar conta dos desdobramentos da etapa que sucede a confecção do texto traduzido, ou seja, depois de traduzido, revisado, editado, impresso, intitulado e revestido pela capa escolhida, qual será o trajeto que o livro estrangeiro, agora vertido para o idioma da cultura receptora, precisará percorrer para chegar às mãos do consumidor final (leitor). Sempre observando o ordenamento cronológico desta fase final do processo investigado, volto primeiramente o foco sobre o cronograma de lançamento da obra traduzida, pois é essa a operação que servirá de ponte entre a editora e o público. Em seguida, abordo a figura do livreiro, importante agente da fase de pós-produção, tendo como fonte o livro de memórias de Pedro Herz (2017), já citado no terceiro capítulo deste trabalho, e o artigo disponível no site Vai Lendo, aludido no capítulo anterior, e o blog Livros, Livreiros e Livrarias, de Jaime Mendes. Essa última fonte, na verdade, é uma compilação de entrevistas feitas com três livreiros que, ao falar de suas experiências, acabam por traçar um perfil dessa profissão tão particular. Por fim, discuto a questão da crítica da tradução, isto é, examino como a tradução de obras estrangeiras costumavam ser avaliadas num passado nem tão distante e como o são hoje, em plena era digital.

No tocante à questão do lançamento de obras traduzidas, segundo a editora Renata Pettengill (2018), são raros os casos em que a versão original e a versão em português são lançadas simultaneamente em seus respectivos mercados. Mais uma vez, entra a internet como marco, pois, na atualidade, o leitor brasileiro toma conhecimento da existência do livro no momento, ou mesmo antes, do lançamento da versão original, e, desde então, passa a aguardar o seu lançamento no Brasil. Há aí um outro ingrediente importante: a questão das culturas hegemônicas. Eu me arriscaria a dizer que o leitor brasileiro é, em maior ou menor grau, muito 
influenciado pela crítica internacional e que, nesse caso, essa avaliação externa pode funcionar como uma credencial para a versão traduzida. Uma vez que se faz o lançamento simultâneo de original e tradução, o leitor brasileiro fica sem esse referencial de qualidade. Pettengill acrescentou ainda que o cronograma de lançamento de uma obra traduzida também pode ser drasticamente comprometido por uma tradução tida como malfeita. O exemplo citado pela editora ocorreu há cerca de quatro anos e se tratava de um thriller psicológico de autoria de uma escritora ${ }^{111}$ muito em voga à época. O equívoco aí se deu porque se confiou a reescrita tradutória a uma escritora brasileira, cuja obra autoral vinha sendo publicada pelo grupo ${ }^{112}$. Dessa forma, verifica-se subjazendo a essa escolha a crença de que o texto autoral é mais difícil, dado o traço eminentemente criativo que lhe é inerente. Uma vez que a tradutora escolhida era considerada capaz de conceber sua própria obra (enredo e texto), a casa editorial parece ter deduzido, ao que parece equivocadamente, que uma tradução, “mero transporte de significados”, haveria de ser feita pela escritora/tradutora com a mesma competência, o que não se verificou naquela ocasião. Entretanto, apesar desse contratempo, as vendas foram um sucesso em razão de dois fatores: o esforço conjunto de uma equipe interna que reparou os problemas identificados na tradução, aprimorando sensivelmente o texto traduzido, e o lançamento do filme homônimo que, tendo rendido uma ótima bilheteria, transferiu o sucesso do cinema para a versão traduzida da obra literária que lhe serviu de origem. Inferese daí que, via de regra, a editora opta por aguardar o lançamento da versão original para, só então, lançar a versão traduzida, com o intuito de gerar no público brasileiro a expectativa de ler aquele livro de cuja existência se tomou conhecimento pela internet. É importante atentar, porém, para o fato de que as editoras brasileiras precisam administrar muito bem o fator "tempo" para que não se gere um gap cronológico muito significativo entre o lançamento do original e o da versão traduzida, para que o leitor não perca o interesse pela obra. Com base nesses dados, parece legítimo afirmar que subjacentes a essa ideia de que o

\footnotetext{
${ }^{111}$ Pelo que se pôde apurar, o último livro de autoria da referida escritora data de 2017. A omissão do nome da autora é proposital para preservar a sua identidade.

${ }^{112}$ Em busca no site oficial da Record realizada em 10/01/2020, detectaram-se dois pontos a considerar: o segundo livro da autora estrangeira lançado pela Record teve outra tradutora, e o nome da escritora/tradutora não figura mais dentre os autores publicadas pelo grupo.
} 
público leitor brasileiro é dependente do referendo internacional para receber bem uma obra estão os conceitos de "cultura dominante” e "cultura dominada”. Essas ideias seriam uma extensão de significado a partir dos conceitos de "língua dominante” e "língua dominada”, elaborados por Pascale Casanova (ver seção 2.6). E pelo que se pode concluir, essa cultura dominante que avaliza a importação de obras literárias para a tradução é, a princípio e em grande parte, anglófona, visto que o inglês é o idioma que há mais de 70 anos vem liderando o ranking de línguas e, por conseguinte, de culturas traduzidas no Brasil.

Responsável pelas compras por parte da(s) livraria(s), o livreiro funciona como termômetro comercial das editoras, e é a sua expertise e o seu senso de observação que as editoras consultam sempre que precisam saber das tendências do momento, se o seu último lançamento está tendo boa vendagem e toda sorte de informação que diga respeito à questão comercial. Vale lembrar que a casa editorial ocupa o setor secundário (indústria) e a livraria, o terciário (comércio), e é o livreiro, ator da cadeia editorial que está mais em contato com o consumidor/leitor, que acaba por construir a ponte entre esses dois setores da economia. Em suma, considerando a cadeia comercial que envolve o produto “livro”, por ser o livreiro o agente que ouve o cliente final desse processo, pode-se tê-lo como o elo entre a indústria editorial e o comércio de livros. Afinal, são as livrarias - físicas ou virtuais - o escoadouro da commodity do mercado editorial. Umas das entrevistas comentadas no artigo disponível no site Vai Lendo foi concedida por Vânia Abreu, diretora comercial da Editora Valentina, mas que atuou como livreira, chegando a ser reconhecida pela Associação Nacional de Livrarias como a Livreira do Ano em 1995. Como define Abreu, o livreiro opera como um mediador entre as editoras e o leitor, pois é ele que sabe o que o cliente final (leitor) busca. Outro profissional entrevistado foi Roberto Pedretti que, dos 16 anos em que atuou no ramo, passou 12 como livreiro especializado na Livraria da Travessa. Além de endossar o que disse Vânia Abreu, Pedretti vai mais além ao atribuir à figura do livreiro a função de “curador”. Para ele, portanto, o livreiro é um profissional que, qualificado para exercer a função, orienta o cliente (leitor), acabando, desse modo, por incrementar o fluxo de leitura. A propósito da profissão, Jaime Mendes, com longa experiência no mercado editorial e hoje diretor de vendas institucionais do GEN (Grupo Editorial Nacional), vinculado à 
Universidade Federal do Rio de Janeiro, em matéria de 2008 veiculada em seu blog Livros, Livrarias e Livreiros ${ }^{113}$, aborda a questão sob alguns ângulos, dentre eles o lexical. Rejeitando a genérica denominação "vendedor”, ele alega que o termo "livreiro" imprime uma identidade ao funcionário de livraria encarregado de atender o cliente e, ao mesmo tempo, ajuda a desfazer uma equivocada imagem de atividade temporária que o senso comum parece ter formado em torno da figura do livreiro. A fim de sustentar seu argumento, Mendes compara o livreiro a vendedores de outros ramos do comércio e alega que um vendedor de artigos de vestuário ou de calçados, por exemplo, não estaria apto a atuar numa livraria. Isso porque, por mais modelos que possa haver disponíveis num estabelecimento comercial desse nicho, estaria ele treinado a trabalhar com apenas três categorias de calçados que são destinadas às fatias da clientela com as quais lida: masculino, feminino e infantil. Já o livreiro precisa lidar com “mais de 2 milhões e 600 mil títulos, para entrega imediata ou a encomendar, e divididos por centenas de áreas” (MENDES, 2008), o que lhe impõe, sobremaneira, o domínio de uma série de áreas, com uma infinidade de subáreas, autores e exemplares cada.

Uma questão recorrente também nesse cenário que, em razão do progressivo avanço tecnológico, tende a se reconfigurar cada vez mais amiúde, é a do futuro da profissão de livreiro. Com o crescimento vertiginoso do comércio eletrônico e com o surgimento dos e-books, previram-se a obsolescência e o consequente fim dessa função. Mesmo admitindo que a profissão precisa passar por profundas mudanças, Roberto Pedretti não teme pela sua extinção, precipitadamente decretada pelos mais pessimistas. Segundo ele, as tradicionais livrarias físicas, de fato, perderam espaço para as virtuais e, em razão disso, o livreiro, de agora em diante, precisará se valer das mídias modernas (blogs, sites, vídeos etc.) para oferecer ao seu cliente (leitor) uma "curadoria digital”. Todo esse panorama tecnológico contrasta sobremaneira com o descrito por Herz em suas memórias. Em meados de 1958, a fim de submetê-lo a uma experiência no exterior e também de prepará-lo para dar continuidade à livraria da família, os pais de Herz o matricularam na Buchhändler Schule, escola para formação de livreiros, localizada na cidade suíça da Basileia. Se o livreiro do século XXI

\footnotetext{
${ }^{113}$ Disponível em: http://livroslivrariaselivreiros.blogspot.com/2008/. Acesso em 04/12/2019.
} 
precisa travar considerável intimidade com as novas mídias que surgem numa velocidade cada vez maior, ao livreiro de meados do século passado eram exigidos conhecimentos administrativos e contábeis que, hoje, são necessários às equipes que lidam estritamente com a parte burocrática do ramo. Desse modo, no distante ano de 1958, para dar conta da livraria da família, Pedro Herz precisou sair do Brasil, carente de cursos dedicados especificamente à formação de livreiros, para aprender a executar tarefas tais como controle de estoque e conferência de faturas. Além do treinamento em tarefas administrativas, o livreiro de meados da década de 1950 também aprendeu a dispor física e visualmente a sua mercadoria - o livro - de forma a dar às prateleiras um toque de "[...] beleza, d[e] uniformidade gráfica” (HERZ, 2017, p. 43), fator ainda de grande importância comercial em se tratando das livrarias físicas, e ainda de competência do livreiro do século XXI. Comparando os relatos dos livreiros entrevistados pelo site Vai Lendo, de um lado, e os de Herz em suas memórias, do outro, parece legítimo afirmar que, acompanhando a tendência contemporânea da formação profissional como um todo, o livreiro, hoje, funciona como um orientador, um influenciador presencial e virtual do leitor/consumidor, tendo, pelo visto, abandonado as atividades burocráticas. Hoje, no Brasil, conforme se pôde apurar, duas instituições oferecem cursos com vistas à formação de profissionais de vendas do ramo livreiro: a UNESP e sua Universidade do Livro, e a Câmara Brasileira do Livro, com a Escola do Livro. Não havendo informações claras com relação à natureza desses cursos, é possível deduzir que se trata de cursos livres, cujo tema de cunho profissionalizante, com módulos independentes e com temas voltados para a área, mas com a organização e o planejamento necessários para formar livreiros de acordo com o as exigências do mercado em pleno século XXI. Dessa forma, tanto a Universidade do Livro (UNESP) quanto a Escola do Livro (CBL) disponibilizam cursos cujo tema está em consonância com as mudanças ocorridas no cenário do comércio livreiro, e que visam a atender às atuais demandas mercadológicas. Assim, em ambas as instituições, os interessados encontrarão programas dirigidos ao mercado editorial lato sensu, contemplando não só a área comercial (gestão), mas também a editorial propriamente dita (revisão e preparação de textos). É curioso notar que, dentre esses últimos programas voltados para questões de natureza textual, nenhum deles está 
diretamente relacionado com a tradução, seja literária ou não. Considerando-se que a tradução integra a cadeia editorial, indaga-se aqui quais as razões que poderão ter motivado tal omissão. No tocante à questão financeira das livrarias, diante do fechamento de filiais de grandes redes de livrarias como a Cultura e a Saraiva, pelo menos num primeiro momento, pode-se atribuir uma relação de causa e efeito entre esse fato e a crise financeira que se abateu sobre o país no período compreendido entre os anos de 2014 a 2016, além do fortalecimento do comércio eletrônico no campo editorial. Em nota intitulada "A falta que um livreiro faz”, publicada na edição de 01/01/2018 do jornal O Globo, o jornalista Ancelmo Góis reproduz a fala de Marcus Gasparian, da Livraria Argumento. Conforme consta da nota, Gasparian deposita na figura do "bom livreiro" a chance de se amenizar qualquer crise, afirmando que "o livreiro não é um simples vendedor”. Ainda sobre a figura do livreiro, ou melhor, sobre a saída de cena desse profissional, a editora Sílvia Leitão (2018) classifica como "livreiro virtual” as "sugestões de leitura”, dadas por sites de livrarias que registram as buscas feitas por clientes. Quando se busca um romance de suspense, por exemplo, em algum lugar da página aparecem outros títulos do mesmo gênero com a inscrição "Estes podem ser do seu interesse”, ou algo similar.

Após o término da etapa editorial propriamente dita, porém, paralelamente à que se ocupa da chegada do produto livro às mãos do consumidor, há uma outra que, dotada de viés analítico e também propagandístico, funcionará como uma espécie de tutor de leitura, favorecendo ou prejudicando a recepção daquela obra traduzida por parte do leitorado da cultura de chegada. Dentre as atividades que constituem essa etapa, podem-se citar: a resenha literária, que consiste em texto jornalístico focado em um livro especificamente, via de regra, recém-lançado; a crítica literária que, abrangendo um gênero de não ficção, é menos imediatista do que a resenha e, por conseguinte, apresenta um certo aprofundamento no assunto; e a fortuna crítica que, por sua vez, pode se conceituar como um conjunto de textos críticos voltados para uma obra ou um autor em particular. Na maioria das vezes, como agentes dessas atividades, encontram-se jornalistas especializados na área da cultura, escritores consagrados, além de mestres e doutores inseridos nos estudos literários, cuja avaliação poderá chancelar a obra analisada e, no caso das traduzidas, poderá, a reboque, avaliar o trabalho do tradutor. Desse modo, é o 
agente da crítica que poderá aproximar ou afastar o leitor da obra e, consequentemente, ajudar a alavancar ou a sepultar as vendas de uma obra literária. Assinale-se aqui, no entanto, que, conforme pude constatar durante a pesquisa e como abordarei mais extensamente a partir deste ponto, muito raramente os agentes da crítica literária se debruçam em especial sobre o trabalho do tradutor, avaliando, no caso de um romance, por exemplo, a obra e seus constituintes narrativos, como os temas abordados, os personagens, a linguagem, sem se deixar claro que o texto ali comentado não é exatamente o escrito pelo autor e, sim, o que foi reescrito pelo tradutor. Em suma, a crítica literária no Brasil, ao apreciar uma obra traduzida, quase nunca leva em consideração o fator "tradução", discorrendo sobre a obra ali em foco como se estivesse em análise o texto autoral. Esquecem-se os críticos, porém, de que houve um mediador que, bilíngue e dotado de habilidade tradutória, possibilitou-lhes a leitura da obra e, por conseguinte, a elaboração do texto analítico que periodicamente publicam em algum jornal. Em razão disso, concluo que, pelo menos no momento atual, não se pratica propriamente uma crítica de tradução como o fizeram Guilherme Figueiredo e Agenor Soares de Moura durante a década de 1940, como veremos mais adiante. O trabalho do tradutor, aos olhos da crítica literária, pelo que se pode inferir, é uma mera etapa editorial, merecendo alguma atenção apenas no caso de um trabalho considerado mal executado.

Sob uma perspectiva diacrônica, Wyler (2003) procura identificar os primórdios da crítica da tradução literária no Brasil, verificando, então, que o exame da qualidade das traduções teve seu início na Era Vargas (1930-1953). Isso porque foi nesse período da nossa história que se implementou um ambicioso programa de combate ao analfabetismo, acarretando, assim, o desenvolvimento da indústria livreira nacional. Ciente de que a literatura estrangeira, de existência incomparavelmente mais longa, consistia numa inestimável fonte de temas, narrativas e padrões estéticos, a então incipiente indústria editorial brasileira intensificou o fomento à tradução de obras provindas de outros sistemas literários. No tocante a um ranking de obras estrangeiras, Wyler nota que, durante esse período, principalmente com o fim da segunda grande guerra, a antes dominante literatura francesa, de forma contínua, perdia terreno para a norte-americana, além da introdução de clássicos da literatura russa. Como consequência da crescente 
importação de obras estrangeiras que se deu no período, veio a também crescente demanda por traduções. Pelo relato de Wyler, deduzo ter havido um desequilíbrio entre os dois quantitativos em tela: a quantidade de obras estrangeiras para a tradução era consideravelmente maior do que o número de profissionais habilitados para executar a tarefa tradutória. Na época, prestando esse serviço para as editoras brasileiras estavam escritores renomados que, dominando as línguas estrangeiras das quais mais se traduzia, teriam a competência necessária para produzir um texto traduzido com a qualidade correspondente à do texto de partida. No entanto, a assimetria numérica a que me referi anteriormente parece ter imposto um impasse: as traduções urgiam e decerto não havia tradutores suficientes para dar conta de tamanha demanda, levando os autores/tradutores a optar por uma das seguintes alternativas: ou traduzir sem fazer a devida revisão ou delegar a tradução a terceiros nem tão qualificados, apenas emprestando o seu nome para agregar valor à obra traduzida. Pelo que pude inferir a partir do que relatou Wyler, o resultado dessa desproporção entre obras a traduzir e tradutores aptos para a tarefa por certo foi uma profusão de traduções avaliadas como de péssima qualidade, fato que se evidenciava em frases de construção estranha à sintaxe portuguesa e termos sem sentido na nossa língua.

Foi justamente nesse período, em meio a uma quantidade de traduções de texto truncado e repletas de incongruências lexicais e sintáticas, como imagino, que, no início da década de 1940, o teatrólogo e ensaísta Guilherme Figueiredo, a convite do jornalista Raul Lima, passou a dirigir o suplemento literário do Diário de Notícias, jornal de grande circulação na cidade do Rio de Janeiro, então capital da República. Já cansado de publicar artigos críticos em que comentava romances por ele tidos como de qualidade duvidosa, conforme relata Ivo Barroso em seu prefácio à obra À margem das traduções (2003), Figueiredo resolve trazer à tona a vulnerabilidade das traduções brasileiras, incluindo as feitas (ou apenas assinadas) por grandes nomes da nossa literatura. Tal empreitada teve por motivação, como relata Barroso, a tradução de O livro de Jó assinada pelo cultuado escritor Lucio Cardoso. A partir daí, a cada edição do jornal, Figueiredo comentava as inadequações - “erros”, sendo que alguns ainda mereciam o adjetivo de “palmares” (“evidentes”), nos dizeres de Barroso (2003, p. 16) - que identificava em traduções brasileiras de obras literárias estrangeiras, independentemente de 
quem tivesse aposto sua assinatura à tradução em foco. Com o apoio de Lima, redator-chefe do jornal, Figueiredo, por meio do suplemento literário então sob sua direção, passou a convocar a participação dos leitores que tivessem detectado estranhezas em traduções. A intenção de Figueiredo era, por meio da participação espontânea dos leitores, alertar os editores para que fossem mais seletivos quando da escolha dos tradutores. Afinal, era a manifestação do cliente final em relação a um produto “com defeito” confeccionado pela casa editorial. Foi então que, dentre a correspondência enviada por leitores, uma se destacou em particular. Assinada por Agenor Soares de Moura, professor da cidade mineira de Barbacena, a carta trazia detalhados comentários acerca de traduções que tinham por textos de partida obras produzidas em sistemas literários como o inglês, o francês, o alemão, o espanhol e o italiano, demonstrando, segundo a avaliação de Figueiredo, não só um profundo conhecimento linguístico e literário, mas também um inequívoco talento para a tradução, além de uma inconteste noção de como se produzir uma tradução de boa qualidade. Diante da profundidade de conhecimento revelado na carta de Moura, Figueiredo decidiu convidá-lo para atuar regularmente como crítico de tradução do jornal. A fim de evitar inimizade com escritores de renome que à época traduziam, Figueiredo teve a ideia de publicar as críticas de Moura sob o pseudônimo C.T. (crítico de traduções). Mesmo com essa blindagem em torno do verdadeiro nome de Moura, foi inevitável o efeito de suas críticas às traduções feitas por escritores consagrados. O Diário de Notícias, então, passou a sofrer pressões não só dos escritores/tradutores criticados, mas também das casas editoriais cujos livros eram objeto do escrutínio de Moura. Como resultado, deixaram de enviar o exemplar estrangeiro e o traduzido para o português do Brasil, sem os quais o cotejo entre original e tradução seria impossível. Para dar continuidade ao trabalho, Moura precisou custear do próprio bolso ambas as edições, a estrangeira e a traduzida, cruciais para realizar o trabalho de crítica que prestava ao jornal. Com o passar do tempo, o alto custo da aquisição das obras, sobretudo as edições estrangeiras, acabou por inviabilizar o trabalho de Moura, que se viu forçado a encerrar suas atividades como crítico de traduções do Diário de Notícias (BARROSO, 2003).

Em uma coletânea de entrevistas lançada em 2016 em comemoração pelos 20 anos do periódico Cadernos de Tradução, nomes proeminentes da tradução no 
Brasil abordam, dentre tantos outros assuntos, a questão da crítica da tradução. Em seu depoimento, Paulo Henriques Britto constata o que afirmei anteriormente: de um modo geral, os textos que têm por finalidade comentar obras literárias, no caso específico das traduzidas, ignoram a tradução, etapa que entendo ser central no processo examinado nesta pesquisa. José Roberto O’Shea, por sua vez, além de corroborar o que disse Britto sobre as raras menções feitas pela crítica à tradução, acrescenta que há pouco espaço aberto pela mídia para esse tipo de análise. Para ele, uma crítica de tradução efetiva, além de precisar contar com um espaço próprio proporcionado pelos meios de comunicação, deveria levar em conta os propósitos a que atende aquela tradução especificamente, assim como os efeitos que possa ter produzido na cultura receptora. A invisibilidade do tradutor que a crítica ajuda a manter é outro tema abordado por O’Shea, que relata um episódio ocorrido com ele mesmo. Ao apreciar um livro traduzido por ele, o resenhista exaltou não só a agilidade, mas também o prazer proporcionado pelo texto (“do autor”), ressaltando que, com tamanha qualidade, a escrita (do autor) conseguiu fazer com que o leitor visse como uma aventura envolvente um período da história pouco estudada nos bancos escolares brasileiros. Mônica Cristina Correa $^{114}$, por seu turno, cita José Paulo Paes ao dizer que "a crítica exige um parti pris” (PAES apud CORREA, 2016, p. 104), ou seja, para que a crítica possa dar seu veredito sobre o quanto uma tradução atende às expectativas do mercado editorial e do público leitor, é preciso estabelecer claros parâmetros avaliativos, critérios estes que mudarão conforme a natureza do texto resenhado e também de acordo com o contexto em que se produziu a tradução avaliada e o público leitor a que se destina. Lia Wyler, notabilizada por traduzir a saga Harry Potter e já mencionada anteriormente, afirma que a crítica da tradução pode se revelar utilíssima, desde que pautada em preceitos teóricos, mormente os desenvolvidos por teóricos brasileiros que se debruçam sobre traduções também brasileiras. Afinal, como postula Toury (1995), a tradução é um fato pertinente à cultura que produz traduções. Ainda na coletânea de entrevistas mencionada (GUERINI et al., 2016), o tradutor e ensaísta Ivo Barroso defende a ideia de que a forma mais "honesta” - termo por ele empregado - de se fazer crítica a um trabalho de

\footnotetext{
${ }^{114}$ Tradutora do francês de obras literárias, de textos jornalísticos e da área de ciências humanas.
} 
tradução é apresentando uma versão melhor do que a criticada. Para tanto, seria condição sine qua non que o crítico fosse também tradutor. Como exemplo, Barroso cita o caso do tradutor francês Henri Meschonnic, que analisou oito diferentes versões para o francês do soneto 27 de Shakespeare. Era de se esperar que o crítico, depois de elencar inúmeros deslizes em cada versão por ele analisada, apresentasse soluções melhores do que as encontradas pelos tradutores criticados. No entanto, segundo avaliação de Barroso, à versão de Meschonnic caberiam as mesmas ressalvas feitas por ele às demais. Por sua vez, João Ângelo Oliva Neto, professor de Letras Clássicas da USP e tradutor do grego e do latim, faz um longo comentário sobre o papel ideal de uma crítica de tradução, abordando tanto a questão terminológica e conceitual, quanto a função que tal atividade deveria exercer. É em razão da multiplicidade de informações contidas em sua resposta que achei por bem desenvolvê-las num parágrafo à parte.

Na concepção de Neto, o raio de ação da crítica de tradução, a rigor, é amplo e contempla desde a resenha feita logo após o lançamento da obra traduzida até a análise dos efeitos produzidos por aquela obra na cultura que a recebe. Para dar conta de todo esse processo, alega Neto, seria necessário que houvesse um certo intervalo temporal para que se pudessem observar os efeitos da recepção. Somente após o decurso desse tempo seria viável examinar aspectos tais como: o quanto aquele autor ou gênero e outras obras produzidas na cultura de origem repercutiram no leitorado receptor; quantos leitores aquela obra conquistou; e se a dimensão desse sucesso foi suficiente para inspirar "outras traduções e obras originais” (NETO, 2016, p. 160). Neto não deixa claro aqui, porém, a que “obras originais” ele se refere, dúvida que se intensifica diante das reflexões teóricas que questionam o termo "original” para se referir a uma obra autoral que serve de texto de partida para uma tradução. Penso que uma obra autoral que tenha alcançado um significativo número de exemplares vendidos (e, consequentemente, lidos) venha a inspirar outras obras autorais não só na cultura de origem como nas demais que a traduziram, como o caso da série $A$ arma escarlate, de autoria da jornalista e escritora carioca Renata Ventura que será comentada mais adiante. Em suma, um grande sucesso editorial é a centelha que fará com que se propaguem obras com características estilísticas semelhantes, cujos autores acalentam o sonho de obterem êxito e reconhecimento, semelhantes 
aos conquistados pelo autor da obra primígena. Para Neto, a crítica de traduções, na condição de análise, deve ter por objetivo precípuo examinar a influência exercida por uma obra traduzida na cultura que a traduziu, seja um texto unitário ou um grupo de textos traduzidos que compartilhem características estilísticas. Como exemplo do que o próprio Neto chama de "repercussão", ele cita o caso dos clássicos da literatura russa que foram traduzidos para o português do Brasil indiretamente, a partir de uma tradução anterior para o francês. Mesmo considerando as imprecisões e os problemas verificados nessas traduções brasileiras, ocasionadas por equívoco do tradutor ou por uma mutilação no original promovida pelo editor para reduzir o texto de partida e acelerar o trabalho tradutório, foi por intermédio dessas versões que, durante a década de 1940, que o leitor brasileiro teve acesso a obras de autores como Dostoviévski, Tolstói e Tchekhov. Esse exemplo citado por Neto enseja aqui a oportunidade para se trazer ao debate o conceito de repercussão, um dos conceitos-ponte desenvolvidos por Chesterman (2007) e apresentados no Capítulo 1 deste trabalho. Segundo o teórico, se por intermédio da tradução - seja de uma obra literária unitariamente ou inserida no que Neto denomina "conjunto orgânico" - uma obra estrangeira for elevada ao status de "cânone" dentro da cultura receptora, se essa obra provoca mudanças na língua alvo, ou se essa obra enseja mudanças nas normas e nas práticas tradutórias, ou mesmo se essa obra for responsável por mudanças na percepção de uma cultura estrangeira, por exemplo, é sinal de que os efeitos produzidos por ela se deram no âmbito cultural. Isso equivale a dizer, como alega Chesterman (2007, p. 180), que a versão traduzida da obra estrangeira conseguiu reverberar de tal forma na cultura de chegada que foi absorvida por seu sistema literário. Como consequência dessa assimilação, acabou por conquistar seu lugar dentre as classificadas como canônicas, ajudando, assim a consolidar o conjunto de obras consideradas como "alta literatura” dentro do sistema literário receptor.

Para fechar este capítulo, examino como a crítica da tradução pode se dar na atualidade, ainda que eventual e pontualmente e, quando ocorre, é feita, quase que, via de regra, de forma amadorística. Assinalo, porém, que não será um exame acurado da crítica de tradução, o que exigiria um profundo estudo sobre o assunto, tema este que por si só consumiria um vultoso número de laudas. Em vez disso, a minha intenção é fornecer uma ilustração de como se dá a recepção - nesse caso, 
a avaliação crítica relativa à tradução, exame análogo ao realizado pela crítica literária - em que abordo um caso envolvendo a tradução de Harry Potter para o português do Brasil. E falar de recepção de obra literária na contemporaneidade é falar de leitura em pleno século XXI, o que, a meu ver, implica necessariamente falar de internet. Como já dito neste trabalho, a era digital não afetou negativamente a atividade da leitura e, muito menos, decretou o seu fim, como se previu de modo equivocado. Contrariando todos os prognósticos, o mundo digital vem se revelando um eficaz espaço de divulgação de obras literárias e, o que considero igualmente importante, vem facilitando sobremodo o cruzamento de fronteiras culturais e linguísticas, permitindo que leitores do mundo todo tenham acesso aos lançamentos (e relançamentos também) da indústria livreira. O mesmo mundo digital que dá acesso à produção do mercado editorial promove também a interação entre leitores que partilham da paixão pelo mesmo gênero ou autor. Essa interconexão ensejou a formação de blogs como o Notas Literárias, administrado por Anastácia Cabo, e outros tantos em que leitores debatem obras as mais variadas. No entanto, conforme disse Cabo, comentários acerca da tradução são esporádicos, tendo a obra em si como o foco das discussões na maior parte das vezes, à semelhança do que ocorre na crítica literária.

Em 6 de julho de 2010, no entanto, o blog Da Penseira ${ }^{115}$ 116, criado para fãs da série Harry Potter, abriu espaço para que internautas debatessem o trabalho de tradução realizado por Lia Wyler. Por intermédio de dois de seus membros, identificados apenas como Patrícia e Daniel, encaminharam-se à tradutora e-mails contendo dúvidas de leitores acerca das soluções por ela encontradas para driblar as dificuldades que se interpuseram em seu caminho. Deve-se salientar aqui que boa parte desses questionamentos versava sobre a questão lexical, visto que a autora J. K. Rowling criou todo um léxico para designar elementos componentes de um mundo também criado por ela. Entretanto, abrindo a sessão e antecedendo os comentários sobre as respostas de Wyler às perguntas dos internautas,

115 Disponível em: http://dapenseira.blogspot.com/2010/07/lia-wyler-e-a-traducao-de-harrypotter.html . Acesso em 20/05/2019.

${ }^{116} \mathrm{O}$ nome do blog é uma referência a um objeto em que os alunos de Hogwarts depositam seus pensamentos, nominado por Rowling como "pensieve" e reescrito por Wyler como "penseira". Fonte:

https://pt.wikipedia.org/wiki/Tradu\%C3\%A7\%C3\%B5es_de_Harry_Potter\#Nomes_de_pessoas,_l ugares_e_coisas. Acesso em 12/03/2020. 
compartilha-se um texto de autoria de Carol, uma terceira participante, em que fala sobre as qualidades de Wyler como tradutora e sobre o seu trabalho de tradução da série Harry Potter especificamente. Além de fã da série, a blogueira se confessa fã também do trabalho de Wyler (“Lia-lover”117, como se autodefine). Os comentários de Carol demonstram uma clara noção de que, para se fazer a análise crítica de uma tradução, é preciso “manter um olhar crítico”"118, isto é, é necessário manter o máximo possível de distanciamento em relação à obra para que a avaliação não se contamine com preferências pessoais. Daniel, o outro participante incumbido de enviar e-mails a Wyler, por ser à época estudante de Letras, foi “considerado mais apto" para tal tarefa, ou seja, o fato de ter conhecimento teórico de língua e literatura lhe serviu de credencial para fazer a triagem das dúvidas a serem enviadas à tradutora.

Em um de seus comentários, o internauta Flavio Jr. tece elogios à tradução de Wyler, destacando as soluções encontradas por ela para nomes como "Maroto" (para "Marauder”, em que a tradutora privilegia o aspecto fonético em detrimento do semântico) e “Quadribol” (para “Quidditch”, jogo fictício criado por Rowling, em cuja reescrita Wyler trabalhou com o sufixo "bol" para remeter à ideia de esporte). No mesmo texto, porém, o leitor se declara "irritado" diante da denominação "Monstro" - infantil, segundo sua avaliação - para "Kreachure”, flagrante referência ao vocábulo "creature". O tom distenso do texto do internauta, ensejado pela informalidade do blog, revela um senso amador de julgamento, não demonstrando possuir o autor qualquer experiência tradutória ou conhecimento teórico sobre a tradução. Já Luan Côrtes, outro participante do debate, apresenta um texto notadamente mais formal, com flagrante atenção ao registro culto. Segundo ele, a manutenção de termos na forma como estão no original denuncia a “desvalorização da língua portuguesa”. Sobre a tradução da obra de Rowling ele avalia que

\footnotetext{
117 Disponível em: http://dapenseira.blogspot.com/2010/07/lia-wyler-e-a-traducao-de-harrypotter.html . Acesso em 20/05/2019.

118 Disponível em: http://dapenseira.blogspot.com/2010/07/lia-wyler-e-a-traducao-de-harrypotter.html . Acesso em 20/05/2019.
} 
Em seu longo comentário, o internauta, além da escrita esmerada, demonstra ter certa noção de teoria da tradução - ou pelo menos intuí-la - ao empregar um termo como "idioma-destino". Além disso, ele entende que, no texto traduzido, inevitavelmente há marcas culturais do tradutor, ou seja, a tradução, na condição de reescrita, contém traços culturais, no caso, de quem a produziu. E esses traços, na sua concepção, precisam prevalecer e se manifestar na língua alvo (“idioma-destino", em suas palavras), para que não se apague na tradução a cultura que recebeu o texto fonte e que produziu a sua tradução.

Participando ativamente do que eu chamaria aqui de "fórum" sobre o trabalho tradutório de Lia Wyler, detectou-se um total de 25 participantes que, ao interagirem entre si, geraram 65 comentários. Mesmo considerando que, para efeitos de um levantamento estatístico mais rigoroso, a marca de 25 no universo de fãs brasileiros de Harry Potter não seria relevante do ponto de vista quantitativo, penso que seja um número suficientemente expressivo para demonstrar que esse debate pode servir de amostragem para os conceitos-ponte de reação e resposta desenvolvidos por Andrew Chesterman (ver Capítulo 1). Cada leitor/fã que comenta os esclarecimentos de Wyler às dúvidas dos leitores revela em seu texto o quanto a tradução afetou cognitivamente cada um deles, como propõe Chesterman (2007, p. 179) na conceituação de reação, visto que a sua recepção do texto traduzido o fez refletir acerca das soluções da tradutora, julgando-as pertinentes em alguns aspectos e, em outros, despropositadas. Dessa forma, o blog reuniu em seu espaço digital 25 internautas que manifestaram suas opiniões a respeito da tradução por eles lida (recepção). Dentre avaliações elogiosas e outras nem tanto, o quadro que se me delineou foi a de um conjunto formado pela expressão do ponto de vista de leitores em relação a uma tradução de cuja leitura partilhavam, o que me credencia a identificar aí o conceito de resposta, ensejado pelo somatório de todas essas reações.

A força narrativa da obra de Rowling, assim como o impacto editorial por ela provocado, produziu efeitos em larga escala no mundo todo, estabelecendo um novo paradigma de narrativa voltada para o público infantojuvenil que em pouco tempo se revelou um sucesso editorial, tendo sido traduzida para dezenas de idiomas. O fascínio exercido pela obra de Rowling inspirou outros autores a produzirem obras com componentes narrativos semelhantes e envoltos na mesma 
atmosfera impregnada de magia, como já dito em outra oportunidade (ver Capítulo 1). Penso que a reverberação dessa influência possa ser entendida como a manifestação empírica de um dos exemplos de repercussão que Chesterman (2007, p. 180) menciona. Se se compreender aqui o termo "cânone"119 como “modelo”, e não propriamente como o entendem os estudos literários, concluo que a saga Harry Potter possa ser vista como um cânone, ou seja, como um padrão de criação literária que, se não propôs uma nova estética exatamente, fez ressurgir por meio da escrita particular de sua autora elementos arquetípicos antes adormecidos, mas que jamais perderam o seu apelo, o seu poder de sedução, como observou Umberto Eco (ver Capítulo 2). No âmbito internacional, também dentro de uma comunidade linguística igualmente anglófona, pode-se detectar a influência da obra de Rowling em Nevermoor: os desafios de Morrigan Crow ${ }^{120}$, romance de estreia da autora australiana Jessica Towsend e publicado em 2019 pela mesma editora Rocco que lançou a série Harry Potter, sendo que, desta feita, pelo selo Rocco Jovens Leitores. O paratexto contido na orelha da edição brasileira fornece elementos que imediatamente remetem o leitor a Harry Potter. Assim como o protagonista da obra de Rowling, Morrigan Crow, desta vez uma menina, carrega desde o nascimento uma maldição, segundo a qual ela morrerá à meia-noite de seu décimo-primeiro aniversário. Assim como Potter, que é levado da casa de seus tios pelo diretor e por uma professora de Hogwarts, Morrigan é resgatada por um homem misterioso que a leva a Nevermoor, cidade cujo conselho administrativo ela passa a integrar depois de vencer perigosos desafios, a exemplo dos heróis da mitologia greco-romana. Note-se o quanto o sobrenome da protagonista $^{121}$, presente no título, é sugestivo para o leitor anglófono, que, ao lêlo, poderá captar, talvez de imediato, que se trata de uma obra marcada por mistério, magia e atmosfera gótica. Uma vez que o nome não foi traduzido na

\footnotetext{
${ }^{119}$ O termo (do grego, “kanon”, espécie de vara de medir) entrou para as línguas românicas com o sentido de "norma" ou "lei". [...] Nas artes em geral e na literatura, que nos interessa mais de perto, cânon significa um perene e exemplar conjunto de obras - os clássicos, as obras-primas dos grandes mestres -, um patrimônio da humanidade (e, hoje percebemos com mais clareza, esta "humanidade" é muito fechada e restrita) a ser preservado para as futuras gerações, cujo valor é indisputável” (REIS, 1992, p. 70).

${ }^{120}$ As informações sobre esse romance foram fornecidas por Raquel Zampil, tradutora da obra e entrevistada para este estudo, realizada em outubro de 2018.

${ }^{121}$ Ao dar à protagonista o sobrenome Crow (corvo, em inglês), a autora já reveste a personagem de uma atmosfera sombria, o que, por ser sobrenome, pode se revelar algo relativo à sua própria origem.
} 
edição brasileira, é provável que o mesmo efeito muito provavelmente não se produza no leitor da cultura de chegada, mesmo se levando em conta que, hoje em dia, o leitor brasileiro, de um modo geral, tenha acesso mais facilitado ao ensino e ao conhecimento de língua inglesa.

No Brasil, no ano de 2011, a jornalista e escritora Renata Ventura lança pela editora Novo Século o primeiro livro de sua trilogia intitulado A arma escarlate, posteriormente lançando também A comissão chapeleira e $O$ dono do tempo, este dividido em dois volumes. Assumidamente inspirada pela leitura da série Harry Potter, da qual se declara fã, Ventura procurou transportar para a cultura brasileira praticamente todos os componentes narrativos da obra de Rowling. Dessa forma, sai de cena Harry Potter e entra Hugo Escarlate, Hogwarts cede lugar à escola de magia Nossa Senhora do Korkovado e seres fantásticos como o Bichento e o Monstro são substituídos por personagens do folclore brasileiro como o curupira, o boitatá e o saci-pererê. Assim como a autora da obra que lhe serviu de inspiração, Ventura aborda por intermédio de sua escrita não só temas pertinentes à adolescência, mas também tempera sua narrativa com assuntos locais como desigualdade social e a violência causada pelo tráfico de drogas, que marcam o cotidiano das favelas cariocas, meio de onde se origina o protagonista. Mesmo não sendo tema contemplado no escopo deste estudo, julgo importante observar, ainda que sem muita profundidade, a questão que envolve a natureza do processo de criação literária de que se valeu Ventura e sua posição em relação à obra de Rowling. Se, por exemplo, Harry Potter e a pedra filosofal é a versão traduzida para o português do Brasil de Harry Potter and the Philosopher's Stone, que teve por mediadora a tradutora Lia Wyler, a mesma relação não se pode estabelecer entre o livro de estreia da saga de Harry Potter e A arma escarlate, o livro que apresenta Hugo Escarlate ao leitor brasileiro. Como tipificar, então, a composição literária de Ventura? Seria uma adaptação da obra de Rowling? Nesse caso, seria o mesmo conceito de adaptação que comumente se usa nos Estudos da Tradução? No entanto, considerando que não houve uma tradução interlingual como em Harry Potter e a pedra filosofal, seria o trabalho de Ventura uma tradução num sentido metafórico? Ou será que o processo criativo de que se valeu Ventura para engendrar as aventuras de seu Hugo Escarlate teria sido uma apropriação? Conforme teoriza Julie Sanders (2006), se a adaptação guarda uma 
semelhança considerável com o texto de origem, a apropriação consiste numa “jornada decisiva que se afasta da fonte de informação e mergulha em um produto e em um domínio culturais inteiramente novos”122 (SANDERS, 2006, p. 26). Pelas análises feitas nos textos consultados para fins deste trabalho, é justamente isso que Ventura parece ter feito em sua trilogia. Apesar de manter os elementos estruturais do texto fonte na construção da sua narrativa, como o protagonista adolescente com poderes mágicos, seres fantásticos e uma instituição escolar criada para desenvolver tais poderes, a autora desloca esses elementos para um panorama completamente diverso do que constituiu pano de fundo para o texto que lhe serviu de inspiração. Um outro ponto que reputo importante assinalar é que, assim como a adaptação, a apropriação é muitas vezes vista como de menor valor, como um sinal de inabilidade criativa por parte do autor, sendo muitas vezes considerada plágio. No entanto, a trilogia $A$ arma escarlate, ao que me parece, e segundo admitiu a própria autora, consiste em uma homenagem à autora cuja obra fez da jornalista Renata Ventura uma autora de livros infantojuvenis. Afinal, como conclui Sanders (2006)

precisamos ver a adaptação e a apropriação literárias sob um ponto de vista mais positivo, encarando-as como novas possibilidades culturais e estéticas que convivem com os textos que as inspiraram, enriquecendo-os, e não os 'roubando' ${ }^{123}$. (SANDERS, 2006, p. 410)

\footnotetext{
122 " [...] a more decisive journey away from the informing source into a wholly new cultural product and domain”. (SANDERS, 2006, p. 26)

${ }^{123}[\ldots]$ we need to view adaptation and appropriation from this more positive viewpoint, seeing it as creating new cultural and aesthetic possibilities that stand alongside the texts which have inspired them, enriching rather than 'robbing' them.
} 


\section{Considerações finais}

Tendo em vista os dados coletados junto a editores e outros agentes que atuam no processo de publicação de obras traduzidas no Brasil, boa parte deles com vínculo atual ou anterior com o Grupo Editorial Record, creio ser legítimo afirmar que o cadinho do mercado editorial brasileiro revelado no presente trabalho já possibilita chegar a algumas conclusões que se poderiam classificar aqui como finais. O que me credencia a fazer tal afirmação é o fato de que as casas editoriais brasileiras, via de regra, seguem normas muito semelhantes no que tange à confecção de obras traduzidas, a despeito de algumas diferenças concernentes aos seus respectivos modi operandi. Tendo isso em mente, passarei a expor as conclusões a que pude chegar ao longo desta pesquisa, tendo por norte não apenas as informações fornecidas pelos entrevistados, muitos deles ligados direta ou indiretamente ao Grupo Editorial Record, mas também as referências teóricas que dão sustento a este estudo. Para fins de organização, seguirei a ordem cronológica aqui adotada, começando pelo estágio da pré-produção, passando pela etapa da produção do texto traduzido (a tradução propriamente dita e os serviços de copidesque e revisão), até chegar à fase de pós-produção, como recapitularei a seguir.

Com base tanto nos relatos dos entrevistados quanto na leitura dos textos teóricos voltados para a tradução no campo editorial, penso ser lícito afirmar que se revelou inequivocamente a ideia da obra traduzida como um produto comercial, confeccionado para atender à demanda de um dos nichos da indústria do entretenimento. Para que a manufatura desse bem de consumo seja executada em sua plenitude, no entanto, é necessário que se articule uma rede de agentes e atividades, como já dito anteriormente. Dotados de habilidades específicas e experiência profissional, esses agentes atuam de forma organizada em cada uma das etapas que constituem o processo de confecção da obra traduzida, de modo geral desconhecidas dos leitores: a de pré-produção (escolha da obra estrangeira e aquisição de direitos autorais), a de produção, esta desdobrada em duas fases (a da tradução propriamente dita e, posteriormente, a da revisão) e a pós-produção (desde a distribuição da obra traduzida no mercado até a sua chegada às mãos ou à 
tela do dispositivo móvel do leitor). Por se tratar de um produto cuja matériaprima é a literatura, mas, ainda assim, um produto manufaturado com vistas à sua comercialização, procurei examinar, da forma mais detalhada possível e tendo por referência o relato de agentes que atuam no campo editorial, as estratégias empregadas para tentar atingir o equilíbrio entre a força exercida pelo vetor artístico-literário e a força exercida pelo vetor comercial. Os exemplos extraídos de entrevistas disponíveis na internet ilustram a dificuldade de se conseguir equalizar esse campo de forças, sobretudo os citados pela editora Laura Bacellar (2014), que praticamente chega a estabelecer uma relação de exclusão entre alta literatura e sucesso de vendas, ideia da qual discordo parcialmente, pois as obras classificadas como tal possuem vendas de cauda longa, ou seja, vendem poucas quantidades por vez, mas essas vendas esporádicas ocorrem ao longo de todo o ano. Isso sem contar com o fato de que, não raro, a indústria cinematográfica faz periodicamente releituras de clássicos, provocando a reboque um aumento das vendas da obra literária que lhe deu origem. A respeito dessa divisão entre alta literatura e literatura comercial, a editora Silvia Leitão (2018) informou que as editoras, de um modo geral, quando resolvem publicar obras de escritores consagrados, autores do que pode se denominar aqui “alta literatura”, estão cientes de que aqueles títulos não terão “vendas massivas e tiragens maiores”. Entretanto, publicar obras esteticamente sofisticadas, além de atender a um nicho específico do público leitor, imprime uma diversidade ao catálogo da editora, o que evita rotular a empresa como puramente comercial. A propósito dos agentes da fase de pré-produção de obras traduzidas, acredito ser possível concluir, com base não só nos relatos das editoras entrevistadas, mas também no material disponível online e aqui utilizado como referência, que o agente literário parece ter a sua atenção mais voltada para o quesito comercial, observando sempre o potencial de vendas de um romance estrangeiro para a tradução. O scout, por sua vez, tem por função identificar, dentro do sistema literário em que está inserido, obras que se coadunem com o perfil da editora que o contrata. Essa diferença parece se evidenciar no que diz a scout Maria Campbell (ver Capítulo 2) a esse respeito: o editor que estiver tão-somente interessado em best-sellers, ou seja, em livros de venda garantida, desconhece totalmente o trabalho desenvolvido pelo scout. A respeito desse agente, em especial, deve-se informar aqui que todas as tentativas 
de se contatar algum foram infrutíferas. Comentando esse insucesso com a editora Suelen Lopes (2019), ela alertou para o fato de que, muito provavelmente, por desempenhar uma função que envolve segredo comercial, o scout - talvez até por orientação da editora que o contrata - evite contato com indivíduos que não sejam diretamente ligados à empresa. Lopes acrescentou ainda que, na casa editorial em que trabalha, mesmo atuando como editora, ela desconhece os scouts que lhes prestam esse serviço.

Em referência à seleção de uma obra com vistas à tradução, primeira tarefa concernente à fase de pré-produção, portanto, pude observar que, a despeito da existência de modernos canais de ligação entre casas editoriais e obras literárias candidatas a tradução, as tradicionais feiras literárias continuam sendo as zonas francas do mercado editorial, sendo a de Frankfurt a mais tradicional e emblemática. É nesses eventos que se dá o contato físico entre agentes literários e representantes de editoras, ou seja, é nas feiras literárias que ocorre a interconexão entre oferta e procura, respectivamente, já que aqui se considera a obra literária um produto comercial. Também concernente à fase de pré-produção, é relevante e, pelo menos para mim, uma novidade, a informação que obtive da designer Renata Vidal (2019; ver Capítulo 4) de que os direitos autorais sobre a publicação de uma obra literária para a tradução encontram-se "fatiados": os direitos autorais sobre uma obra em si, ou seja, sobre o texto propriamente dito, constituem um processo, e os direitos sobre a reprodução da capa constituem outro. A conclusão a que pude chegar em relação ao quesito “direitos autorais” é a de que o texto literário a ser traduzido e o layout que o reveste, por serem de naturezas e de autores distintos, requerem processos de aquisição de direitos autorais feitos igualmente à parte. Há situações, porém, segundo o relato do diretor de marketing Bruno Zolotar (2014), em que texto e capa podem ser inclusos no mesmo pacote comercial, caso a editora brasileira julgue, de antemão, ser importante que se reproduza a capa original. É o caso das obras voltadas para o leitorado jovem. Ainda concernente à aquisição dos direitos autorais, está a questão dos leilões, promovidos no caso de obras e/ou autores que atraem o interesse de mais de uma editora. O leilão, pelo que posso inferir, é um bom termômetro para avaliar o potencial de vendas da obra de um autor novo ou, então, para aferir o capital simbólico de um autor com expressivo lastro de obras vendidas. 
No tocante à etapa de produção do texto traduzido, há alguns aspectos que observei durante a minha pesquisa e que registro aqui à guisa de conclusões finais. Reitero, porém, o que foi dito logo no início desta tese quanto a ter sido necessário, por uma questão de recorte de pesquisa, optar por priorizar a geração de dados junto ao Grupo Editorial Record por se tratar de uma editora de grande porte, que abriga diversos selos, com práticas editoriais não necessariamente homogêneas, além de ter sido a editora que sempre se mostrou receptiva ao meu trabalho.

O primeiro ponto para o qual chamo a atenção se refere à formação do tradutor. Mesmo sabendo que, no âmbito do estado do Rio de Janeiro, a PUC-Rio, por exemplo, forma, tanto em nível de graduação quanto de pós-graduação lato sensu, profissionais qualificados na área de tradução, poucos são os tradutores prestando serviço para a Record que têm essa formação específica, seja pela PUCRio ou por outra instituição de ensino. A tradutora Raquel Zampil, pelo que se percebe, é uma exceção num universo quantitativamente considerável de profissionais traduzindo para um grupo editorial da envergadura da Record, este, por sua vez, composto por selos editoriais que publicam bastantes obras traduzidas. Pelo que pude verificar com base nos relatos dos entrevistados, boa parte dos tradutores prestando serviço para a Record tem por característica o domínio de determinados assuntos em discussão no texto fonte, no caso de não ficção, e, no caso de obras literárias, um sólido conhecimento sobre algum autor ou algum gênero literário em especial. Somado a isso, a editora exige de seus tradutores habilidade redacional de modo a produzir um bom texto traduzido, entendendo-se por "bom”, de acordo com a ótica do mercado editorial, um texto que espelha o original (conteúdo e forma) e, em caso de itens de intraduzibilidade, tenham a aptidão para adaptá-los de forma a não causar estranhamento ao leitor da tradução. Um outro dado que pude verificar ao longo das entrevistas é que, atualmente - e, ao que parece, isso não se restringe ao Grupo Editorial Record os tradutores hoje em atividade no campo editorial brasileiro começaram a traduzir por indicação. O que parece apropriado afirmar é que, de uma forma ou de outra, o primeiro trabalho de tradução feito para a editora contratante servirá de referência para se avaliar a qualidade profissional do tradutor. E, na organicidade 
do processo editorial, a baliza aferidora do trabalho do tradutor é o saldo total de interferências feitas pelo copidesque no texto traduzido.

O segundo ponto a se considerar concerne à ausência de uma inter-relação entre tradutores e revisores, lacuna que detectei quando prestei serviços de copidesque a uma editora concorrente da Record. Os relatos dos participantes desta pesquisa só vieram a corroborar algo que já à época intuí: a ausência de contato, físico ou virtual, entre os agentes responsáveis pela confecção e pelo aperfeiçoamento do texto traduzido. Apesar de tradutores, copidesques (= preparadores de originais), revisores, independentemente da nomenclatura adotada pela editora, compartilharem o mesmo "subproduto", que é o texto traduzido ainda em fase de produção, raramente há uma interação entre esses atores objetivando dirimir dúvidas, trocar informações, ideias e sugestões, com vistas ao aprimoramento do resultado final: um texto que proporcione ao leitor uma leitura que transcorra sem obstáculos, como recomenda o briefing da editora contratante. Exceções a essa regra podem ocorrer no caso de tradutores específicos, aqueles com grande capital simbólico e que desfrutam de total confiança dos editores. Mesmo quando esse processo de lapidação textual é executado por equipes internas das casas editoriais, dificilmente se estabelece uma intercomunicação entre tradutor, colaborador externo, e o revisor, neste caso, na maioria das vezes, funcionário da editora. Considerando a importância dessa integração interpessoal para a obtenção de um bom resultado final, como propõe Alasdair McIntyre (ver Capítulo 1, seção 1.6), mesmo reconhecendo haver, por parte de alguns copidesques e revisores, o desejo de ascender ao status de tradutor, pus-me a aventar hipóteses que pudessem dar conta da(s) razão(s) para que essas atividades sejam desenvolvidas de forma isolada e praticamente estanque. A conclusão a que cheguei, sem descartar qualquer outra possível, diz respeito especificamente ao cronograma elaborado pela editora para o lançamento de obras traduzidas. Vale lembrar que tanto nas entrevistas realizadas para este estudo quanto nas disponíveis no meio digital e aqui consultadas, o fator "internet” foi citado como divisor de águas no que tange à adoção, por parte da indústria editorial, de uma nova política de produção e divulgação, sobretudo em se tratando de obras traduzidas. Assim, o leitor, ao tomar conhecimento do lançamento de um romance estrangeiro, por exemplo, passa a ficar alerta para o lançamento dessa obra no 
Brasil. Se entre os dois eventos houver um interstício considerável ${ }^{124}$, as vendas da versão traduzida serão drasticamente afetadas. Esses fatores me levam a inferir que, na hipótese de a editora franquear essa interconectividade entre tradutores e copidesques, poder-se-iam travar inúmeras e infindas discussões acerca das escolhas do tradutor e suas subsequentes alterações feitas pelo copy, o que certamente afetaria negativamente a sinergia editorial. A propósito desse assunto, o copidesque Rodrigo Austregésilo (2019) informou que toda e qualquer mediação entre tradutor e revisor que se faça necessária é realizada pelo editor. Isso equivale a dizer que a decisão final sobre o que vai ou não ao prelo é do editor, ou seja, o texto traduzido que o leitor lê é resultado final da deliberação do editor. Ao que parece, essa pressão referente ao cronograma parece ter uma maior intensidade quando se trata de obras de cunho comercial, uma vez que, considerando-se o quesito "interesse do leitor", esse tipo de obra parece ser consideravelmente efêmero. Por conseguinte, no caso de obras que se insiram na categoria “alta literatura”, dada a sua perenidade, a tensão relativa à agenda de lançamento no Brasil parece ser mais amena, salvo se, por alguma razão especial, haja necessidade de se abreviar esse processo.

Ainda dentro da fase de produção do texto traduzido, outro fator que saltou aos olhos se refere à imparcialidade cobrada de tradutores e revisores. O interessante foi observar que o distanciamento em relação ao texto original, de cuja cobrança se queixam muitos tradutores, é exigido do copidesque não só por parte da editora contratante, mas também por parte de uma tradutora, como mostra a epígrafe ao artigo de 2015 de Flavia Carneiro Anderson (ver Capítulo 3). As palavras da tradutora Regina Motta, citada por Anderson, parecem indicar que há uma crença tácita de que, em relação ao texto traduzido, o tradutor goze de uma certa condição de autoria, não conferida ao copidesque. O que as práticas editoriais examinadas deixam implícito, então, é que a tradução constitui uma atividade executiva, no sentido de "produtora", enquanto que a do copidesque, de cujo agente se cobra habilidade tradutória - é vista como de natureza meramente receptiva. Do ponto de vista legal, o status de autoria é conferido ao tradutor pela Lei 9610/1998 (inciso XI, artigo $7^{\circ}$ ), fazendo-se refletir, formal e ostensivamente,

\footnotetext{
${ }^{124}$ Segundo a editora Suelen Lopes, dois meses de intervalo entre os dois eventos já é suficiente para trazer prejuízos à casa editorial.
} 
no documento de cessão de direitos autorais que o tradutor precisa assinar ao ser contratado para a tradução de uma obra, obrigação de que o revisor é dispensado. Ao que tudo indica, o campo editorial atribui a tradutores e revisores patamares de importância diferentes, o que parece se refletir na ficha catalográfica e demais páginas informativas, que raramente exibem o nome do responsável pela preparação de originais, para empregar aqui o outro termo adotado para designar ao profissional do texto responsável pelo cotejo entre texto fonte e texto alvo.

Ainda sobre a questão da autoria - ou coautoria - do tradutor, creio que à ideia de avocar para o tradutor a autoria do texto, de certa forma, subjaz a noção de superioridade da autoria em relação à tradução, ou seja, parece haver uma necessidade de aplicar à figura do tradutor o rótulo de "autor”, mesmo admitindo que o processo de tessitura do texto traduzido, com toda a complexidade que o envolve, é trabalho, ou melhor, é obra do tradutor, como assim o reconhece o texto da lei de direitos autorais. Entendo que, no que diz respeito ao tradutor e à tradução, o que falta é conscientizar o consumidor de traduções a importância não só da atividade como também de seu executor, pois, sem eles, a leitura da obra estrangeira seria, se não impossível, pelo menos dificultosa para o leitor. Talvez fosse o caso de as entidades representativas, como o SINTRA e a ABRATES, promoverem eventos divulgados pela grande mídia, ou mesmo se utilizando das redes sociais, com o intuito de trazer à tona algo que foi ocultado pela ilusão de se estar lendo o original. Esse trabalho de divulgação revelaria a natureza do trabalho do tradutor, que é a habilidade de recriar aquela obra literária numa cultura e língua diferentes das de origem. Se o trabalho do escritor conta com o beneplácito da liberdade criadora, o trabalho do tradutor precisa se submeter às amarras das diferenças culturais e linguísticas e, não raro, às restrições editoriais que parecem ter por norte a ideia de "seguir de perto o original". Por essa razão, creio que a competência do tradutor reside na sua habilidade de criar um novo texto que represente o estrangeiro que lhe deu origem, talento que, segundo compreendo, é a junção de duas habilidades: a de interpretar o texto fonte, no sentido jakobsoniano (2010, p. 81), processá-lo e, em seguida, transformá-lo de modo a ser aceito pela cultura receptora. Ao cumprir essas etapas - interpretação, processamento e transformação - o tradutor terá atuado como o mediador do ato comunicativo em que consiste a tradução. 
Falar da imparcialidade requerida de tradutores, copidesques e revisores nos remete ao conceito venutiano de invisibilidade. A esse respeito destaco a posição de Ivone Benedetti, posição da qual partilho, como já afirmado no capítulo 3 deste trabalho. Considerando os dois tipos de invisibilidade, a textual e a social, entendo que, se, por um lado, é a invisibilidade social que há de ser combatida por vias legislativas como propõem Ribeiro (2015) e o PL 1220/2015, por outro, creio ser na invisibilidade textual que resida a tônica da atividade do tradutor. Talvez a rede de ensino poderia ser uma poderosa parceira nessa empreitada para jogar luz sobre a tradução e o tradutor. Creio que os programas de literatura do ensino médio, por exemplo, poderiam incluir traduções de obras estrangeiras, dentre clássicos e obras contemporâneas, orientando os professores para chamar a atenção do alunado sobre o fato de que, para que aquela leitura fosse possível, foi necessário que um profissional da linguagem, o tradutor, intervisse para reescrever aquele texto em português que eles têm nas mãos. Penso que a figura do tradutor só será socialmente visível quando se mostrar ao leitor, cliente final da indústria livreira, a complexidade da atividade tradutória que resultou no texto que ele está levando para casa. O leitor precisa ser conscientizado do árduo trabalho que possibilitou que ele estivesse com aquela obra vertida para o seu vernáculo, a despeito da existência de ferramentas tecnológicas que amenizam toda essa dificuldade e abreviam o tempo empregado na tarefa tradutória. No que diz respeito à gênese da invisibilidade do tradutor, um outro dado que Benedetti acrescenta e que, para mim, foi esclarecedor, é o fato de a tradução literária, diferente da técnica, se dar num meio em que a tradução é um fim em si mesmo. Pelo fato de o tradutor literário e o agente de patronagem que publica obras literárias transitarem pelo mesmo campo, o editorial, não há um distanciamento entre os dois atores, posicionados hierarquicamente, figurando o tradutor como prestador de serviço e a casa editorial como contratante. Desse modo, editores, representantes da casa editorial perante os tradutores, ainda que sem experiência tradutória, entendem que estão a cavaleiro para avaliar a qualidade do trabalho do tradutor, decidindo se ele continuará ou não a traduzir para a editora.

Uma questão ainda pertinente à fase da produção do texto traduzido concerne à proximidade ou ao afastamento da tradução em relação ao texto fonte, 
sendo, portanto, referente à atividade em si e não ao seu agente em especial. Pelo que pude apurar, há uma tendência a se preservar ao máximo o texto de origem na sua “totalidade”, ou seja, manter no texto alvo todos os elementos culturais representados no espaço ficcional criado pelo autor no texto de partida, com o intuito de proporcionar ao leitor brasileiro a experiência de conhecer um cenário diverso do seu, mas transformado linguisticamente de tal modo que essa imersão não seja afetada. Diante dos casos de intraduzibilidade, por exemplo, pelo que pude depreender do relato de Raquel Zampil (2018), o tradutor apresenta as soluções que lhe ocorreram para que o editor avalie e decida se alguma delas procede. Do contrário, essa dificuldade é encaminhada à equipe interna, que decidirá o que irá ao prelo. Acredito que as exceções se restrinjam a determinados projetos tradutórios destinados a um público muito específico, como o infantil e o juvenil, por exemplo, em que a editora opta por adaptar dados culturais muito diversos dos da cultura receptora, em nome de uma leitura o mais fluente possível.

No que tange à última fase do processo examinado, alguns pontos merecem destaque. O primeiro se refere à mudança de cenário promovida pela internet, fator já mencionado neste trabalho. Oferecer ao consumidor de obras traduzidas um preço reduzido, proporcionado pela ausência dos custos gerados por uma loja física (aluguel, energia elétrica, serviços de telefonia e banda larga, para citar alguns), sem falar na remuneração do vendedor, popularizou o comércio eletrônico de bens de consumo de um modo geral, incluindo os produzidos pela indústria editorial. A despeito dessa mudança, ao que parece, a profissão de livreiro está mais ativa do que nunca, fato que se comprova pela existência de cursos como os oferecidos pela Universidade do Livro (UNESP) e pela Escola do Livro (CBL), com a finalidade de formar e qualificar livreiros e cujas grades curriculares refletem essa abertura de perspectiva, como abordado no capítulo $5^{125}$

Ainda no tocante à recepção da obra traduzida, um dado interessante se revelou: a figura do fã. A razão de minha surpresa em relação a esse ator, que

\footnotetext{
${ }^{125}$ Haviam sido planejadas entrevistas com livreiros no intuito de investigar a participação desses profissionais nos sites oficiais das livrarias e também em blogs e canais do Youtube, por exemplo. Entretanto, todas as minhas tentativas nesse sentido foram infrutíferas.
} 
ocupa a ponta final da cadeia aqui examinada, é que a geração analógica a que pertenço foi estigmatizada por não cultivar o hábito da leitura, preferindo consumir o que, à época, se denominava “enlatados televisivos”. Tal estigma foi tão marcante para a geração que adolesceu durante a década de 1970 que a ausência do hábito da leitura chegou a ser tema de redação no vestibular, outrora unificado. Em contrapartida, a geração que já nasceu imersa no mundo digital vem se revelando um grupo formado por leitores contumazes. Esse mesmo meio digital que, a princípio, poderia pôr fim ao hábito da leitura, ao contrário, vem servindo como meio de divulgação de obras especialmente escritas para o deleite desses jovens leitores. Eventos literários como a Bienal do Livro e a Flip, a cada edição, vêm atraindo milhares de fãs, empolgados para conferir as novidades do mercado editorial e, em alguns casos, ver pessoalmente o autor de cujos livros são aficionados. É importante ressaltar, porém, que o leitor contemporâneo, sobretudo se pertencer à parcela nascida já no século XXI, hoje já na casa dos 20 anos, não se restringe à condição aparentemente passiva do leitor das gerações anteriores, cujo canal de comunicação com as editoras se limitava ao envio de cartas. O leitor contemporâneo, principalmente se também ocupa o status de fã, tem uma participação mais ativa e, valendo-se do meio digital, expressa sua opinião sobre os lançamentos da indústria editorial. Alguns foram mais além, como o caso dos fãs da série Harry Potter, e se puseram a refletir sobre as escolhas da tradutora para o vocabulário particular da obra, emitindo suas opiniões, umas elogiosas e outras discordantes. Ao observar a discussão online acerca da tradução de Lia Wyler para a obra de J.K. Rowling, foi inevitável fazer a conexão à convocação feita por Guilherme Figueiredo, em meados da década de 1940, aos leitores do Diário de Notícias para que, por meio de cartas, apontassem as soluções encontradas pelos então tradutores/escritores. Identifico na ponte entre os leitores do mundo digital e os do Brasil pós-guerra uma rica fonte de pesquisa para se formar perfis de leitor, o que creio ser útil para a indústria livreira.

A partir deste ponto, tentarei fazer uma conexão entre teoria e prática tendo por campo de observação os relatos dos participantes das entrevistas realizadas para esta pesquisa. A primeira delas diz respeito ao postulado de EvenZohar de que a literatura traduzida se integra à nacional trazendo consigo novos gêneros textuais e novas poéticas. Em se tratando do sistema literário brasileiro, 
no prefácio à coletânea de artigos "Literatura traduzida e literatura nacional" (2008, p. 7), inclusa nas referências, os organizadores citam escritores, tidos como canônicos, que se nutriram de literatura traduzida para produzirem as suas próprias obras: Gregório de Mattos, Castro Alves, Machado de Assis, Guimarães Rosa e Clarice Lispector. Penso ser inegável o fato de que a literatura traduzida opera como vetor de oxigenação estética do sistema literário tradutor. O que verifiquei é que, a despeito de instrumentos legais como o Decreto 75.699/75 que, ao promulgar a Convenção de Berna, reconhece que a tradução é propriedade intelectual do tradutor a cuja figura, assim, confere relevância, as editoras e as livrarias brasileiras, de um modo geral, ainda deixam velada a atividade linguístico-cultural que viabilizou a leitura daquela obra estrangeira por parte do público leitor. Desse modo, creio que, se o leitor brasileiro, ao acessar os espaços digitais ou físicos de editoras e livrarias, visse expresso "literatura traduzida” em vez de "literatura estrangeira", a atividade tradutória estaria ali patente. Ainda que, num primeiro momento, a substituição causasse alguma estranheza no leitorado receptor, deduzo que essa troca, pelo menos a médio prazo, contribuiria de forma subliminar para lançar luz sobre a tradução e o tradutor, atividade e profissional imprescindíveis para a indústria editorial de uma cultura significativamente tradutora como a brasileira, mas que ainda se encontram diluídos numa cadeia de agentes e atividades.

Um outro ponto a acrescentar aqui diz respeito à premissa de Gideon Toury de que a literatura traduzida ingressa no sistema literário receptor para preencher algum tipo de lacuna, seja como veículo para inserir um gênero literário desconhecido da cultura tradutora ou uma nova proposta poetológica. Por tudo revelado ao longo do meu estudo, considerando o campo por mim observado e analisado, parece-me lícito afirmar que, muito mais do que suprir uma "carência literária”, por assim dizer, a tradução de obras estrangeiras se constitui, na verdade, num modo de circulação de capitais de toda natureza: de bem de consumo (o livro propriamente dito), que, a meu ver se trata de um produto de valor agregado; de capital cultural (o conteúdo literário veiculado pela tradução); e de capital simbólico (o autor do texto fonte que, se novato, poderá ter notabilizado o seu trabalho ou, se já consagrado, manterá seus status de “personalidade literária”). No tocante a este último, seria interessante que 
entidades representativas dos tradutores como o SINTRA e a ABRATES dessem continuidade ao seu projeto de concentrar esforços, por intermédio de ações concretas, como, por exemplo, a apresentação de proposições legislativas compostas com sugestões feitas pelos próprios tradutores, para que a classe possa um dia vir a usufruir de capital simbólico semelhante ao do autor, o que só seria possível se o tradutor vier a se tornar visível aos olhos do grande público. Vale lembrar também que a indústria editorial não só se "autoalimenta”, ou seja, produz para oxigenar a si mesma, como também alimenta outros nichos dessa mesma indústria, como o cinema, a televisão (aberta ou por assinatura) e as mídias mais contemporâneas, como as plataformas de transmissão online (streaming), como o Netflix, por exemplo. A pujança econômica da indústria editorial revela-se notadamente nos esforços empreendidos pelas editoras brasileiras, incluídos aí todos os agentes a elas ligados direta ou indiretamente, quando das feiras literárias. Em suma, a tradução literária é uma peça integrante de uma engrenagem industrial e comercial, que é o mercado livreiro.

Outro conceito que ficou claramente demonstrado durante a minha pesquisa foi o de patronagem, concebido como um sistema por André Lefevere. Observei pelos relatos dos entrevistados, agentes que desempenham alguma função dentro do campo editorial, que uma rede de profissionais se articula de forma ordenada, ou seja, de modo sistêmico, como propõe Lefevere, objetivando a importação de literatura para a sua subsequente tradução. Dentre esses agentes, incluem-se casas editoriais representadas por agentes literários, scouts e os próprios autores que, mesmo tendo ali por procuradores seus agentes literários, estando presentes nas feiras literárias, podem não só acompanhar a negociação dos direitos autorais sobre suas obras, mas também potencializar o capital simbólico que já possuem por terem sido por eles escritas. A partir da observação dos dados coletados, entendo que o sistema de patronagem que se organiza e opera para produzir e vender literatura, nacional ou traduzida, subdivide-se em dois grandes setores: o editorial (setor secundário, a indústria) e o livreiro (setor terciário, o comércio), ambos trabalhando em parceria para vender livros, dentre eles os traduzidos. Em suma, casas editoriais e livrarias se articulam para promover a confecção e a comercialização de literatura, incluindo a traduzida, ou seja, a indústria editorial e o comércio livreiro constituem um sistema binomial 
com vistas a vender o produto literário. Essa parceria, porém, vem sofrendo drásticas mudanças causadas pelo comércio online. Se antes as editoras dependiam das livrarias para escoarem a sua produção, hoje as vendas podem ser feitas pelo site das próprias editoras, fato que vem transformando em concorrentes as outrora parceiras. Outro fator que vem contribuindo para essa mudança de cenário foi o surgimento de sites de vendas como o Amazon, por exemplo, que se notabilizou, pelo menos num primeiro momento, por ser uma plataforma de vendas de livros.

Quando da escolha de uma obra estrangeira e do profissional para traduzila, os conceitos de habitus e de capital simbólico, concebidos por Pierre Bourdieu, mostram-se evidentes. Assim, verifica-se o valor da obra e/ou autor dentro do seu sistema literário de origem, assim como uma eventual topicalidade e/ou relevância para a cultura meta, para, só então, importá-la/o, trazê-la/o para esse último sistema. Obra estrangeira selecionada, em seguida, na fase da tradução, procura-se o tradutor que, ao longo de sua vida profissional, travou intimidade, desenvolveu um profundo conhecimento daquele gênero textual, daquele assunto ou do estilo daquele autor. Identifico aí uma relação de causa e efeito entre os conceitos bourdiesianos de habitus e de capital simbólico, pois entendo que este é a coroação, a legitimação daquele. Dessa maneira, mediante o conhecimento e os trabalhos realizados ao longo de sua carreira, autores e tradutores, dadas as devidas diferenças e proporções, alcançam status de respeitabilidade, de prestígio em suas respectivas tarefas.

No que tange à ideia de Lawrence Venuti de que, via tradução, podem-se formar imagens de outras culturas, imagens estas muitas vezes equivocadas e imbuídas de preconceito e/ou fantasia, como evidenciado nas capas feitas para o romance Inferno, de Patrícia Melo, conforme mencionado no Capítulo 3, devo admitir que minha tentativa de verificar esse aspecto foi frustrada, uma vez que não foi possível coletar dados suficientes para formular uma hipótese. Segundo seu relato, a designer de capa Renata Vidal nunca recebeu nenhum briefing do qual constassem orientações que viessem a culminar numa representação doméstica de uma cultura estrangeira. No entanto, ao ampliar a objetiva voltada para a ideia de Venuti, pude identificá-la diluída durante as etapas seletiva (préprodução) e elaboradora (produção) do processo editorial. Na etapa de pré- 
produção, ao selecionarem títulos para a tradução, agentes literários e scouts escolhem quais culturas vão entrecruzar com a cultura tradutora no campo editorial. Na etapa seguinte, a de produção textual, essas culturas estrangeiras são lidas e traduzidas (tanto no sentido lato quanto no estrito), em um processo em que a digital da cultura fonte estará indelevelmente imprimida na cultura receptora. Concluída a fase textual, sobrevirá a etapa de apresentação da obra traduzida em que os elementos paratextuais fornecerão ao leitor informações que formarão um conjunto de traços identitários que, por sua vez, influenciarão a forma como o leitor perceberá a cultura ali representada. Fora do campo editorial, no acadêmico, outros agentes operam para configurar as obras traduzidas dentro da cultura de recepção. Professores conferem importância a determinadas obras estrangeiras (e traduzidas) ao incluí-las em suas bibliografias e ementas. Considerando o número de pessoas que partilham da leitura das mesmas obras traduzidas, seja essa leitura feita por motivação acadêmica ou apenas por lazer, parece legítimo afirmar que a atuação dos agentes tanto do campo editorial quanto do campo acadêmico acaba por provocar o que Chesterman nomeia como "repercussão".

No que diz respeito aos conceitos-ponte invocados por Chesterman (ver Capítulo 1, seção 1.5.1), creio que todos, à exceção do último, “convergência”, que concerne mais propriamente ao aspecto teórico dos Estudos da Tradução, puderam ser identificados, clara ou subliminarmente, nos dados coletados. O primeiro conceito-ponte comentado por Chesterman, a causalidade, permeia toda a cadeia, foco desta pesquisa, visto que se trata do que motivou a tradução de um texto estrangeiro (causa) e os reflexos produzidos por essa tradução no grupo social que a solicitou (efeitos). Penso que a causalidade, da forma como conceitua Chesterman, manifeste-se mais nitidamente na fase de pré-produção, quando se decide que obra estrangeira importar e traduzir e, na pós-produção, sobremaneira, nas resenhas críticas e, mais contemporaneamente, nos blogs literários de que participam leitores, fãs de autores e gêneros textuais. Quanto ao trinômio “prática, discurso e habitus”, infiro serem os conceitos que permeiam a fase da tradução propriamente dita. Segundo Chesterman, a tradução, historicamente, se autodefine como uma prática, executada por um agente humano dotado de conhecimento, visão de mundo e experiência tradutória (habitus $=$ conhecimento + visão de 
mundo + experiência) que, ao traduzir, articula o texto por ele traduzido não só com outros textos, mas também com o contexto em que estão inseridos naquele momento. O seguinte grupo tripartite de conceitos, "normas, briefing e estratégia”, transita entre as fases de pré-produção e de produção. As normas e o briefing, de um lado, são elaborados pelo agente de patronagem e precedem a tradução, servindo de norte para a confecção do texto traduzido. As estratégias, por seu turno, são os recursos de que dispõe o tradutor para elaborar a tradução em observância às normas e ao briefing, ou seja, para que a demanda do agente de patronagem seja satisfeita da forma mais plena possível, é preciso que o tradutor se valha de seu habitus para lançar mão das estratégias adequadas para cada projeto tradutório. Por fim, o grupo "reação, resposta e repercussão" se refere à forma como a tradução é recebida pelo leitor, seja o crítico literário ou pelo leitor comum. Em se tratando da recepção deste último grupo, penso que o fórum promovido pelo blog Da Penseira para discutir a tradução de Lia Wyler da série Harry Potter, comentado no capítulo 5 deste trabalho, ilustre a forma sequencial como o processo da reação-resposta-repercussão, partindo dos efeitos da tradução produzidos num indivíduo, em seguida, produzidos num grupo e, por fim, numa cultura.

Por tudo até aqui exposto, penso que minha pesquisa tenha coletado dados suficientes para evidenciar que a tradução, na condição de atividade, de ato performático com uma determinada finalidade, como propõem os funcionalistas, move uma malha de agentes para que a sua execução se perfaça em conformidade com a solicitação do agente de patronagem contratante. A indústria editorial, como componente da indústria do entretenimento, envolve um considerável número de profissionais que se engajam em projetos, incluindo aí aqueles que têm por objetivo publicar obras estrangeiras, importadas para a tradução, visando a atender às necessidades de um determinado público leitor. Esse leitor, como afirmado na introdução deste trabalho, raramente tem consciência da complexidade operacional e do número de agentes engajados em cada uma das etapas em que se desdobra o processo de confecção de um produto literário traduzido. No entanto, entendo que a tradução, mesmo sendo uma dentre várias etapas, constitui-se na atividade central no processo de publicação de obras literárias traduzidas. E ainda que não seja a primeira a ocorrer ao longo de toda a 
linha do tempo em que ocorre esse processo, a tradução literária, na condição de atividade fim, como destaca Benedetti (2003, p. 23-24), é a que viabilizará as demais que compõem essa cadeia produtiva, que nem sempre é visível ao grande público. 


\section{Referências}

AGUIAR, Ofir Bergemann de. Tradução e literatura: os folhetins traduzidos e a introdução da obra de ficção em prosa. In: MARTINS, Marcia (org.). Tradução e multidisciplinaridade. Rio de Janeiro, Lucerna, p. 136-152, 1999.

ANDERSON, Flávia C. A (não) relação entre tradutores e copidesques no processo de edição de obra estrangeira. Tradução em Revista, n.2, versão online, p. 37-67, 2015.

AUSTREGÉSILO, Rodrigo. Entrevista concedida a Lana Beth Ayres Franco de Araujo. Rio de Janeiro, 15 de jul. 2019.

BACELLAR, Laura. Entrevista disponível em < http://didabessana.wixsite.com/historiasdolivro> Acesso em 09/09/2019.

BARBARA, Vanessa. O preparador, esse desconhecido. Disponível em: $<$ http://www.blogdacompanhia.com.br/2011/01/o-preparador-essedesconhecido>. Acesso em 15/01/2018.

BASSNETT, Susan. Translation Studies. London/New York: Routledge, 2014.

BELTRÃO, Renata. Harry Potter contra o preconceito literário. Disponível em: https://lombadaquadrada.com/2017/07/01/harry-potter-contra-o-preconceitoliterario/. Acesso em 27/12/2019.

BENEDETTI, Ivone; SOBRAL, Adail (orgs.). Conversas com tradutores: balanços e perspectivas da tradução. São Paulo: Parábola Editorial, 2003.

BEST BOLSO. Disponível em: $<$ http://www.record.com.br/grupoeditorial.editora.asp?id.editora=12>. Acesso em 04/10/2018.

BEST BUSINESS. Disponível em:

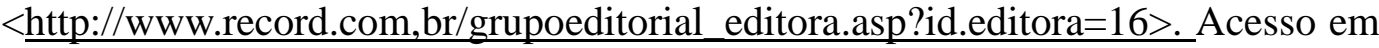
02/10/2018.

BRASIL, Lei $\mathrm{n}^{\circ}$ Lei $\mathrm{n}^{\circ}$ 9. 610, de 19 de fevereiro de 1998. Altera, atualiza e consolida a legislação sobre direitos autorais e dá outras providências. Disponível em http://www.planalto.gov.br/ccivil_03/leis/19610.htm. Acesso em: 08/12/2019.

BRASIL, Portaria No 3.264, de 27 de setembro de 1988, publicada no Diário Oficial em 3 de outubro de 1988. Disponível em < https://www.sintra.org.br/osintra/>. Acesso em 17/07/2020. 
BROOKS, John. Aventuras empresariais. Disponível em: < https://www.record.com.br/produto/aventuras-empresariais/, Acesso em 09/03/2020.

BUZELIN, H. Sociology and Translation Studies. In: MILLÁN, C; BARTRINA, F. The Routledge Handbook of Translation Studies. London/New York: Routledge, 2013, p. 186-200.

BUZELIN, H. Unexpected Allies. How Latour's Network Theory Could Complement Bourdieusian Analyses in Translation Studies. In: INGHILLERI, M. (Ed.) Bourdieu and the Sociology of Translation and Interpreting. The Translator, Special Issue. Manchester, UK: St. Jerome, 2005, p. 193-218.

CABO. Anastácia. Entrevista concedida a Lana Beth Ayres Franco de Araujo. Rio de Janeiro, 06 nov.2018.

CARNEIRO. Teresa Dias. Entrevista concedida a Lana Beth Ayres Franco de Araujo. Rio de Janeiro, 28 de novembro de 2018.

CASANOVA, Pascale. Consecration and Accumulation of Literary Capital: Translation as Unequal Exchange. In: BAKER, Mona (ed.). Critical Readings in Translation Studies. New York : Routledge, 2010, p. 285-303.

CASARIN, Rodrigo. O homem que é rei de um reino onde não vive ninguém nem ele mesmo. Disponível em:https://paginacinco.blogosfera.uol.com.br/2017/06/28/o-homem-que-e-rei-deum-reino-onde-nao-vive-ninguem-nem-elemesmo/\#: :text=P\%C3\%A1gina\%20Cinco,O\%20homem\%20que\%20\%C3\%A9\%20rei\%20de\%20um\%20reino,vive\%20nin gu\%C3\%A9m\%20\%E2\%80\%93\%20nem\%20ele\%20mesmo\&text=O\%20rei\%20 Javier\%20Mar\%C3\%ADas. Acesso em 27/12/2019.

CHESTERMAN, Andrew. Bridge Concepts in Translation Sociology. In: WOLF, M.; FUKARI, A. (eds). Constructing a Sociology of Translation. NY/Amsterdam: John Benjamins, 2007, p. 171-183.

CHESTERMAN, A. O nome e a natureza dos estudos do tradutor. Trad. Patrícia Rodrigues Costa; Rodrigo D’Ávila Braga Silva. Belas Infiéis, v. 3, n.2, p. 33-42, 2014.

CIVILIZAÇÃO BRASILEIRA. Disponível em: $<\underline{\text { http://www.record.com.br/grupoeditorial_editora.asp?id_editora }=5}>$. Acesso em 15/09/2019.

COMPANHIA DAS LETRAS. Disponível em: $<$ www.companhiadasletras.com.br/autor.php?codigo $=02815>$. Acesso em $10 / 11 / 2017$. 
DA PENSEIRA. Blogspot. Disponível em: http://dapenseira.blogspot.com/2010/07/lia-wyler-e-a-traducao-de-harrypotter.html . Acesso em 20/05/2019.

D’ARÊDE, Juliana. Profissão: livreiro - vendendo livros e sonhos. Disponível em: <https://www.vailendo.com.br/2018/03/14/profissao-livreirovendendo-livros-e-sonhos/> Acesso em: 20/11/2018.

Dicionário eletrônico Houaiss da língua portuguesa 3.0.

EDITORA ALBATROZ. Disponível em: < https://editoraalbatroz.com.br>. Acesso em 08/09/2019.

EDITORA RECORD. Disponível em: <http://www.record.com.br/grupoeditorial.30/07/2019>. Acesso em 30/07/2019

GALERA RECORD. Disponível em:

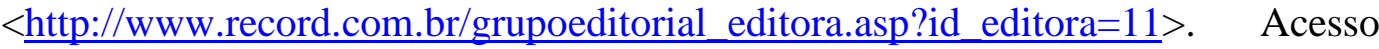
em 22/09/2019.

GALERINHA RECORD. Disponível em: $<$ http://www.record.com.br/livro_sinopse.asp?id_livro=28688>. Acesso em 22/09/2019.

GASKELL, Elizabeth. Mary Barton. Tradução e prefácio de Juliz Romeu. 1a edição, Rio de Janeiro, Record, 2017.

GENETTE, G. Paratextos editoriais. Trad. Álvaro Faleiros, Cotia, SP: Atheliê Editorial, 2009.

GOUANVIC, J. A Bourdieusian Theory of Translation, or the Coincidence of Practical Instances. Field, "Habitus", Capital and "Illusio". In: INGHILLERI, M.(Ed.) Bourdieu and the Sociology of Translation and Interpreting. The Translator, Special Issue. Manchester, UK: St. Jerome, 2005, p. 147-166.

GRÁFICO DE TÍTULOS EDITADOS E PRODUZIDOS - Novos Números de ISBN. Disponível em: http://pesquisaeditoras.fipe.org.br. Acesso em 15/12/2019.

GUERINI, Andréia et al. (org.). Literatura nacional e literatura traduzida. Rio de Janeiro: 7Letras, 2008, p. 7-50.

GUERINI, Andréia; TORRES, Marie-Hélène C.; COSTA, Walter Carlos (Orgs.). Vozes tradutórias: 20 anos de Cadernos de Tradução. Florianópolis: DLLE/UFSC, 2016.

HALLEWELL, Laurence. O livro no Brasil: sua história. Trad. Maria da Penha Villalobos, Lólio Lourenço de Oliveira e Geraldo de Souza. $3^{\mathrm{a}}$ ed. São Paulo: Editora da Universidade de São Paulo, 2012. 
HEILBRON, Johan. Towards a Sociology of Translation: Book Translations as a Cultural World System. In: BAKER, Mona (ed.). Critical Readings in Translation Studies. New York : Routledge, 2010, p. 304-316.

HEILBRON, J.; SAPIRO, G. Outline for a Sociology of Translation: Current Issues and Future Prospects. In: WOLF, M.; FUKARI, A. (eds). Constructing a Sociology of Translation. NY/Amsterdam: John Benjamins, 2007, p. 93-105.

HERZ, Pedro. O livreiro: como uma família que começou alugando 10 livros na sala de casa construiu uma das principais livrarias do Brasil, São Paulo, Planeta do Brasil, 2017.

HOLMES, James. The Name and Nature of Translation Studies. IN: (https://archive.org/stream/Holmes1972TheNameAndNatureofTranslationStudies/ Holmes\%201972\%20The\%20Name\%20and\%20Nature\%20of\%Translation\%20S tudies_djvu.txt).

IMMONEM, S.; MÄKISALO, J. Pauses Reflecting the Processing of Syntactic Units in Monolingual Text Production and Translation. IN: https://www.researchgate.net/publication/320588892.

JAKOBSON, Roman. Linguística e comunicação. São Paulo, Cultrix, 22a edição, 2010, p.79-91.

JOSÉ OLYMPIO. Disponível em < Disponível em: https://www.record.com.br/editoras/jose-olympio/. Acesso em 27/10/2019.

KLEIN, Lisa. Ofélia. Disponível em: <https://www.record.com.br/editoras/joseolympio/>. Acesso em 09/03/2020.

KOŞ, Ayşenaz. Analysis of the Paratexts of Simone de Beauvoir's Works. In: PYM, Anthony; PEREKRESTENKO, Alexander (eds). Translation Research Projects 1. Tarragona: Intercultural Studies Group, p. 59-68 (http://www.intercultural.urv.cat/research/kos/).

LEFEVERE, A. Tradução, reescrita e manipulação da fama literária. Tradução de Claudia Matos Seligman. Bauru, SP, Edusc, 2007, p. 29-49.

LEITÃO, Silvia. Entrevista concedida a Lana Beth Ayres Franco de Araujo. Rio de Janeiro, 6 set. 2018.

LIVROS, LIVRARIAS E LIVREIROS. Blogspot. Disponível em: $<$ http://livroslivrariaselivreiros.blogspot.com/2008/>. Acesso em 04/12/2019.

LOPES, Suelen. Entrevista concedida a Lana Beth Ayres Franco de Araujo. Rio de Janeiro, 20 nov. 2019.

MACHADO, Carolina. Manual de sobrevivência do revisor iniciante. Belo Horizonte, Moinhos, 2018. 
MELO, Patricia. Inferno. São Paulo, Companhia das Letras, 2000.

MELO, Patricia. Inferno. Translated by Clifford E. Landers. London, Bloomsbury Publishing, 2002.

MILTON, John. A importância de fatores econômicos na publicação de traduções: um exemplo do Brasil. TradTerm, 17, 2010, p. 85-100.

MISES, Ludwig von. As seis lições. Tradução de Maria Luiza Borges, $7^{a}$ edição, São Paulo, Instituto Ludwig von Mises Brasil, 2009, p. 13-25.

. Marxismo desmascarado. Tradução de Alexandre S. Campinas, SP, VIDE Editorial, 2015, p. 125-139.

MOURA, Agenor Soares de. À margem das traduções. Apresentação: Paulo Rónai; organização: Ivo Barroso, São Paulo: Arx, 2003.

MONTEIRO, Júlio Cesar Neves. Literatura brasileira e literatura traduzida no Brasil. Cadernos de Tradução n 31, Florianópolis, 2013/1, p. 141-153.

MORTIMER, Ian. Centuries of Change. Disponível em: https://www.goodreads.com/book/show/20493659-centuries-of-change. Acesso em 27/10/2019.

MUNDAY, Jeremy. Introducing Translation Studies - Theories and Applications. London/New York: Routledge, 2012.

NESPE. Núcleo e Estratégias e Políticas Editoriais. Disponível em: $<$ http://nespe.com.br/curso-preparacao-e-revisao-de-textos/>. Acesso em 15/07/2020.

OUSTINOFF, Michaël. Tradução: história, teorias e métodos. Tradução do francês de Marcos Marcionilo, São Paulo, Parábola Editorial, 2011.

PARÁBOLA EDITORIAL. Disponível em https://www.parabolablog.com.br/index.php/blogs/a-importancia-da-traducaopara-o-mercado-editorial?tmpl=component\&print=1\&format=print. Acesso em 10/12/2019.

PAZ E TERRA. Disponível em: $<$ http://www.record.com.br/livro_sinopse.asp?id_livro=29354>. Acesso em 18/09/2019.

PETTENGILL, Renata. Entrevista concedida a Lana Beth Ayres Franco de Araujo. Rio de Janeiro, 4 set. 2018. 
PORTO ALEGRE. Matéria da coluna de cultura. Disponível em $<\underline{\text { https://gauchazh.clicrbs.com.br/cultura-e-lazer/noticia/2020/04/autor-canadense- }}$ processa-editora-por-incluir-trechos-petistas-em-seu-livrock9f73yiw000001s0q943599t.html>. Acesso em 13/07/2020.

PYM, Anthony. On the Social and the Cultural in Translation Studies. In: PYM, Anthony; SHLESINGER, Miriam; JETTMAROVÁ, Zuzana. Sociocultural Aspects of Translating and Interpreting. Amsterdam: Benjamins Translation Library 67, 2006, p. 1-25.

PYM, Anthony. The Translator as Non-Author, and I am Sorry About That. In: BUFFAGNI, Claudia; GARZELLI, Beatrice; ZANOTTI, Serenella (eds). The Translator as Author: Perspectives on Literary Translation. Berlin, Lit. Verlag, 2011, p. 31-44.

REIS, Roberto. Cânon. In: JOBIM, José Luiz (org.) Palavras da crítica. Rio de Janeiro: Imago, 1992, p. 65-92.

SAPIRO, Gisèle. Translation and the field of publishing. Translation Studies. 1: 2, 2008, 154-166.

SANDERS, Julie. Adaptation and Appropriation. London/New York, Routledge, 2006, p. 26-41.

SETTE, Maria de Lourdes. Entrevista concedida a Lana Beth Ayres Franco de Araujo. Rio de Janeiro, 5 dez. 2018.

SETTE, Maria de Lourdes. Nem autor, nem coautor. Tradutor. Revista de Letras da Faculdade da Região dos Lagos - FERLAGOS, vol. 1 (1), 2003.

SHUTTLEWORTH, M. Polysystem theory. IN: BAKER, Mona (ed.). Routledge Encyclopedia of Translation Studies. London/New York, Routledge, 1998.

SIMEONI, Daniel. Between Sociology and History: Method in Context and in Practice. In: WOLF, M.; FUKARI, A. (eds). Constructing a Sociology of Translation. NY/Amsterdam: John Benjamins, 2007, p. 187-204.

STUART, Keith. O menino feito de blocos. Tradução de Ana Carolina Delmas, Rio de Janeiro, Record, 2016.

The Free English Dictionary. Disponível em

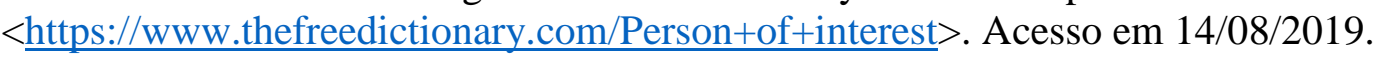

TOURY, Gideon. Descriptive Translation Studies and Beyond. NY/Amsterdam: John Benjamins, 1995, p. 23-39.

TOURY, Gideon. Descriptive Translation Studies and Beyond. NY/Amsterdam: John Benjamins, 2012, p. 197-211. 
TYMOCZKO, Maria. Ideology and the Position of the Translator: in What Sense is a Translator "In Between”? In: CALZADA-PEREZ, M. (ed). Apropos of Ideology. Manchester, UK: Sr. Jerome, 2003. P. 181-201.

VENUTI, L. A formação de identidades culturais. In: VENUTI, L. Escândalos da tradução. Trad. L. Pelegrin, L. Villela, M. Esqueda e V. Biondo. Bauru: EDUSC, 2002, p. 129-167.

VENUTI, L. The Translator's Invisibility: A History of Translation. Second Edition, London/New York. Routledge, 2008, p. 1-34.

VIDAL, Renata. Entrevista concedida a Lana Beth Ayres Franco de Araujo. Rio de Janeiro, 23 nov. 2018.

WOLF, M. The Emergence of a Sociology of Translation. In: WOLF, M.; FUKARI, A. (eds). Constructing a Sociology of Translation. NY/Amsterdam: John Benjamins, 2007, p. 1-36.

WYLER, L. Línguas, poetas e bacharéis: uma crônica da tradução no Brasil. Rio de Janeiro: Rocco, 2003.

ZAMPIL, Raquel. Entrevista concedida a Lana Beth Ayres Franco de Araujo. 14 out. 2018.

ZOLOTAR, Bruno. Entrevista disponível em < $<$ www.homoliteratus.com/escrevere-uma-parte-do-trabalho>. Acesso em 08/09/2019. 


\section{ANEXO A}

Gaskell acredita ser a solução para a sociedade de Manchester é um retorno a uma ética cristã, em que a solidariedade e a capacidade de perdoar fariam com que as diferenças naturais entre ricos e pobres deixassem de ser cruéis.

O triângulo amoroso de Mary Barton e a trama policial na qual ele resulta complementam de forma perfeita a discussão da condição dos pobres trazida por meio da figura de John Barton. Gaskell consegue amarrar as duas partes do livro num final emocionante, digno de um romance policial, dando à heroína, Mary, um papel muito mais ativo do que o da maioria das protagonistas da época. Com isso, mesmo que discorde da solução de Elizabeth Gaskell para mitigar as desigualdades entre classes, o leitor contemporâneo terá dois bons motivos para se interessar por Mary Barton: 0 retrato realista de uma cidade e seus habitantes numa época que repercute no modo em que vivemos até hoje; e uma velha e boa história de amor e assassinato, daquelas de nos deixar roendo as unhas até a última página.

Julia Romeu escritora e tradutora

GASKELL, Elizabeth. Mary Barton. Tradução e prefácio de Juliz Romeu. $1^{\text {a }}$ edição, Rio de Janeiro, Record, 2011. 


\section{ANEXO B}

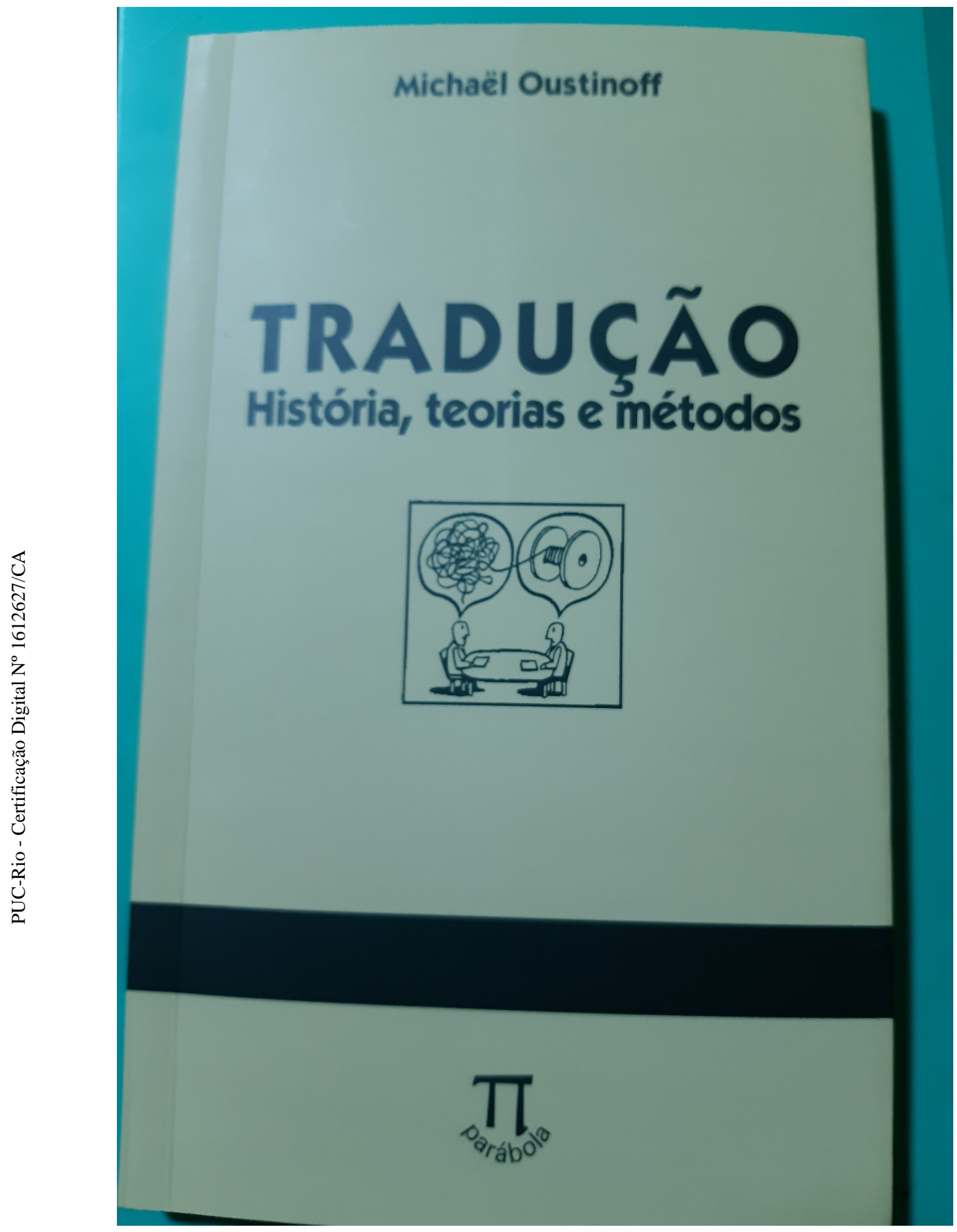

OUSTINOFF, Michaël. Tradução: história, teorias e métodos. Tradução do francês de Marcos Marcionilo, São Paulo, Parábola Editorial, 2011. 


\section{ANEXO C}

\section{Michaël Oustinoff}

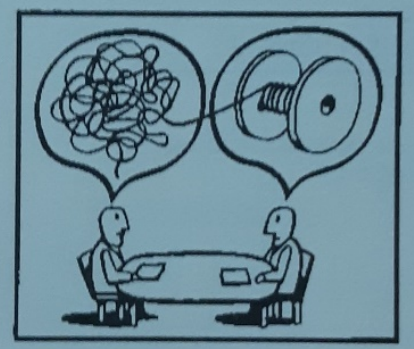

\section{TRADUÇÃO DO FRANCÊS}

Marcos Marcionilo

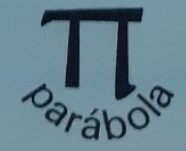

OUSTINOFF, Michaël. Tradução: história, teorias e métodos. Tradução do francês de Marcos Marcionilo, São Paulo, Parábola Editorial, 2011. 


\section{ANEXO D}

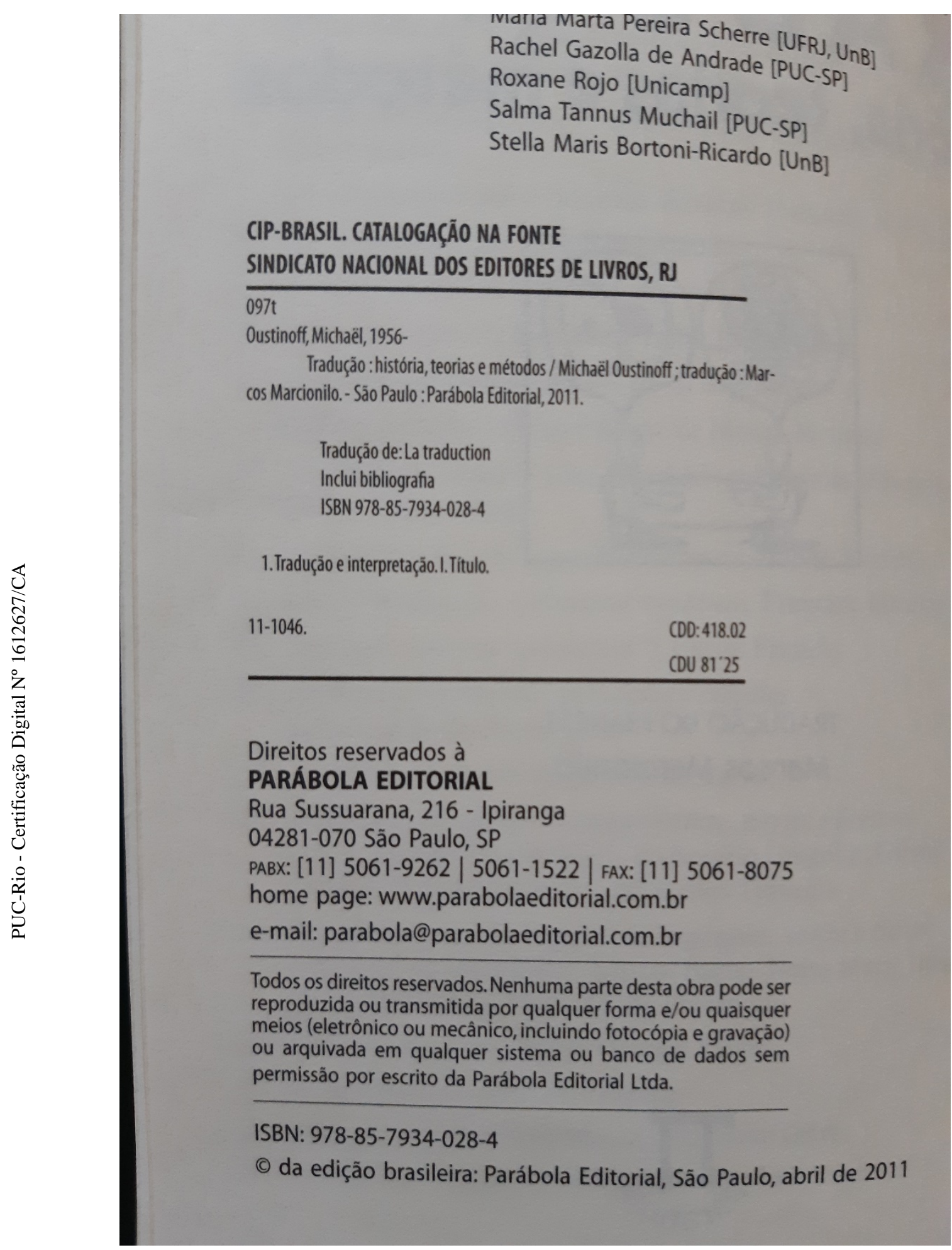

OUSTINOFF, Michaël. Tradução: história, teorias e métodos. Tradução do francês Marcos Marcionilo, São Paulo, Parábola Editorial, 2011. 


\section{ANEXO E}

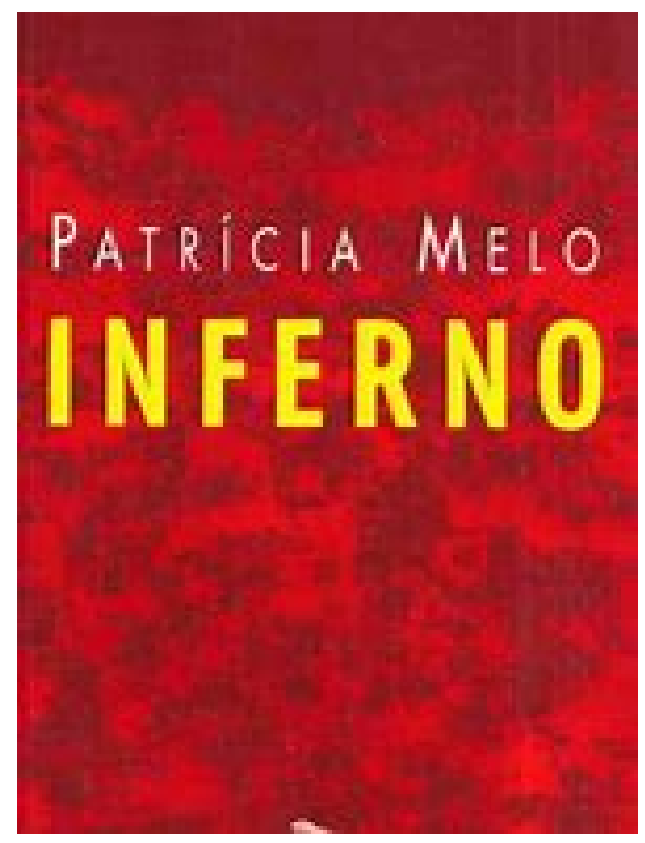

Capa original (Companhia das Letras)

MELO, Patricia. Inferno. São Paulo, Companhia das Letras, 2000.

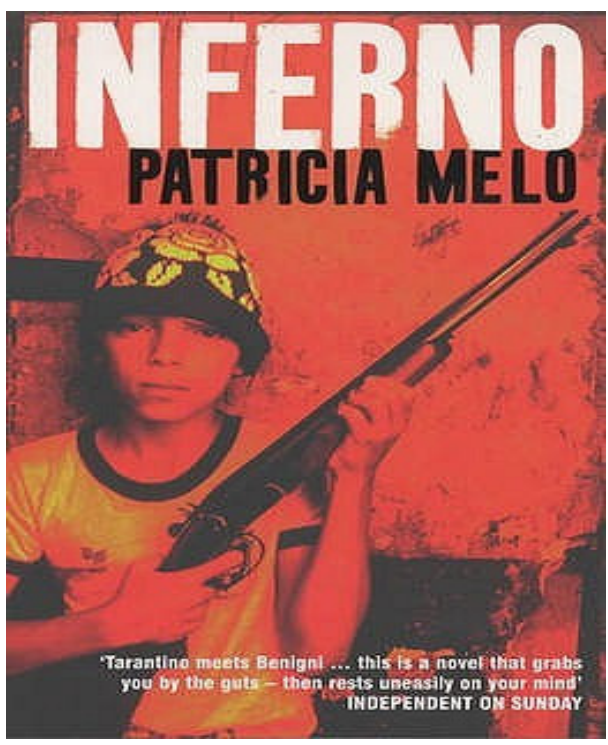

Capa da versão traduzida para o inglês (Bloomsbury Publishing) MELO, Patricia. Inferno. Translated by Clifford E. Landers. London, Bloomsbury Publishing, 2002. 
ANEXO F

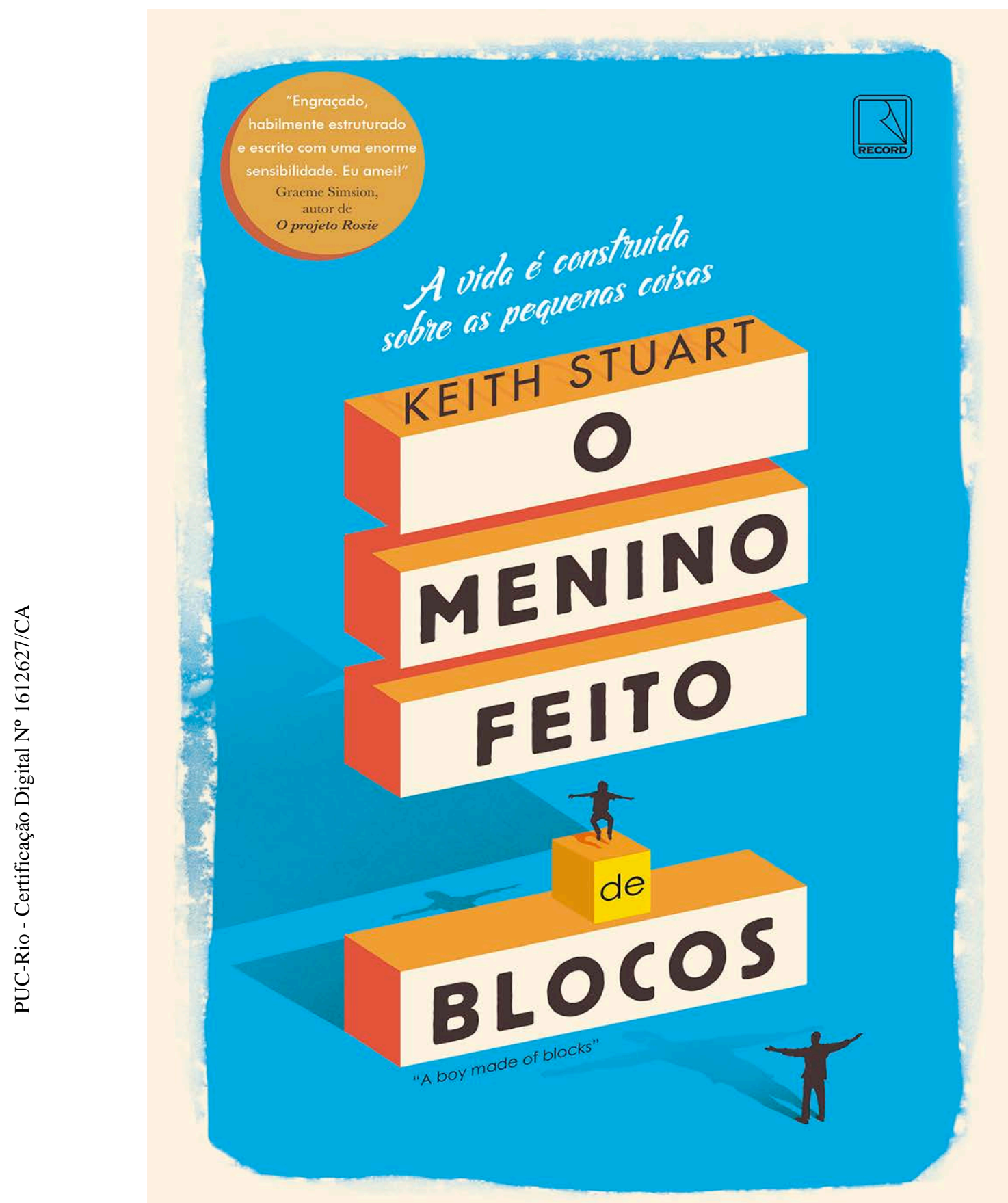

STUART, Keith. O menino feito de blocos. Tradução de Ana Carolina Delmas, Rio de Janeiro, Record, 2016. 


\section{ANEXO G \\ Entrevista concedida pela editora Renata Pettengill, do Grupo Editorial Record (04 de setembro de 2018)}

Lana: Quais os critérios do Grupo Record para a escolha de um livro para ser traduzido?

R. Pettengill: Quando se trata de tradução, a gente tem a opção de escolher de uma gama de livros publicados no mundo inteiro. Então, a gente pode chegar a esse livro por pesquisa particular. Eu resolvi ir atrás de um livro que eu sei da existência dele informalmente pelas redes sociais, pela internet, jornal ou uma revista ou, o que é mais comum, os livros são apresentados a nós pelos agentes literários. Todo ano, eu vou pelo menos a três encontros, em que eu falo com agentes literários do mundo todo. Normalmente em março ou abril é a London Book Fair, em setembro eu vou a Nova York conversar com os proprietários americanos dos livros lançados nos Estados Unidos especificamente, em outubro tem a Feira de Frankfurt, onde agentes literários de todas as nacionalidades se encontram. Aí você tem reuniões das 9 da manhã às 6 da tarde e de meia em meia hora você conversa com um agente literário diferente que vai apresentar a você os livros que ele acha que vão ser melhores para a sua editora, para o seu mercado. Então, a partir daí, a gente olha, de toda a gama disponível no mundo todo e avalia o que a gente consegue e escolhe um ou outro. A gente tem ajuda de scouts. A gente tem scout na Inglaterra e nos EUA. E o que faz um scout? Todo dia eles recebem material novo de agentes e editoras. O dos EUA faz relatório semanal e os ingleses, diário de tudo o que há de novo lá. Eles fazem a leitura dos livros e fazem os relatórios de leitura e apontam o que acham que vai ser mais interessante para nós, porque eles já conhecem mais o nosso mercado, mais do que o agente literário, porque os scouts trabalham para nós (para o Grupo Record) e os agentes literários trabalham para o mundo todo. $\mathrm{O}$ scout sabe o que a gente quer e fica de olho no que está disponível no mercado. Assim que a gente faz a escolha, o livro vai a leilão - ou não - por ele. No momento (...) a assinatura do contrato para publicar o livro. É assim que a gente faz a seleção.

Lana: Então esse scout trabalha especificamente para uma editora, enquanto o agente literário trabalha com várias?

R.P.: Exatamente. Cada editora no Brasil tem o seu scout e cada scout tem contato com todos os agentes literários daquele mercado e aí eles fazem os reports. Os reports dos livros de autores americanos são feitos pelos scouts em Nova Iorque e os dos autores ingleses pelos scouts em Londres.

Lana: Esses leilões que você mencionou são comuns de acontecer, quer dizer, é comum se adquirirem os direitos autorais via leilão?

R.P.: Quando o livro interessa a mais de uma editora, e as duas editoras mandam uma oferta para o agente literário, o agente literário tem que abrir um leilão para 
não ter que escolher uma em detrimento da outra. Aí as editoras fazem os seus lances e, se depois de algumas rodadas, ainda não se chegou a uma conclusão, se não houver muita diferença entre uma oferta e outra, aí eles determinam uma data de best offer em que a gente oferece o máximo e quem oferecer a maior best offer ganha o leilão.

Lana: E em relação à escolha do tradutor, por exemplo. Vocês devem ter vários perfis de tradutor, acredito.

R.P.: Eu gosto de escolher o tradutor que tenha algum histórico de traduzir aquele tipo de livro ou aquele tipo de assunto, porque vai ficar mais fácil para ele fazer o trabalho. Aqui na Record especificamente, no passado, qualquer pessoa que se dissesse tradutor acabava traduzindo pra cá e isso deu muito problema, porque tem muito livro antigo que, quando a gente resolve publicar e vai olhar a tradução está toda horrível. Aí você tem que passar por uma revisão de tradução e o negócio fica mais caro e demorado. O que eu tenho feito agora é: primeiro, pensar na pessoa que eu acho que seria ideal para fazer aquele livro e depois pedir que ela faça uma primeira parte, umas dez páginas, pra que a gente possa fazer um cotejo e já dar um feedback para que, antes de ela dar continuidade ao trabalho, saber a minha opinião sobre o que ela fez para que, no fim, saia de acordo com o que eu estou esperando, que corresponda às minhas expectativas.

Lana: Vocês exigem ou dão preferência a tradutores que tenham formação em Letras, que tenham alguma formação acadêmica na área de tradução ou não?

R.P.: É sempre um algo a mais, passa na frente de pessoas que não tenham, mas, por exemplo, eu tenho um caso muito interessante que é de um cidadão que é do IME, é engenheiro e é fã de ficção científica e aí, na década de 90, quando eu trabalhei aqui pela primeira vez, ele ajudava a editar a Isaac Asimov Magazine e fazia umas traduções e ele é muito bom. Aí, depois, quando eu saí da Record em 98, eu perdi contato e, quando eu voltei, eu me lembrei dele e disse "vou tentar entrar em contato com ele”, porque eu tinha contratado uma ficção científica e aí eu pensei "Poxa, ia ser perfeito!”. Ele aceitou fazer e ficou maravilhoso. Ele é engenheiro, mas é muito bom tradutor. Ele traduz livro de cálculo e coisas assim, mas, mesmo para prosa, literatura, ele é maravilhoso. A tradução dele fica perfeita. Então, não necessariamente (a pessoa precisa ter formação em Letras), não é nenhuma restrição, não.

Lana: E, por exemplo, você tem a tradução de um best-seller, de leitura fluida, fácil, e a retradução de um clássico.

R.P.: Ah, não, aí a gente tem que pegar tradutor de pedigree. Por exemplo, a gente tinha Umberto Eco ano passado pra mandar pra tradução e eu não conhecia bons 
tradutores de italiano além do Marco Lucchesi, mas o Marco Lucchesi estava ocupado e não podia fazer. Aliás, ele comentou que estava fazendo mais tradução de poesia. A gente tentou também o Caetano Galindo, mas o prazo era justinho e ele não se sentiria bem fazendo. Aí, eu continuei procurando até que achei a Ivone Benedetti, que é fantástica, e aí a gente... não tem jeito, tem que ir pra um tradutor que tenha pedigree.

Lana: O que você chama de pedigree exatamente?

R.P.: É quando a pessoa é premiada, que tem traduções premiadas, quando tem milhares de anos de experiência, que é reconhecido em todo o mercado, se você pedir indicação do melhor tradutor de italiano (por exemplo) e todo mundo vai indicar aquela pessoa e que, quando a tradução chegar, você não vai mexer em nada, porque, se você mexer, ela vai reclamar. Foi o caso de uma tradução do italiano para o português feita pela Ivone Benedetti. A gente fez a revisão aqui, mas ela quis ver cada uma das correções e não aprovou várias delas e explicou por quê, ou seja, a pessoa sabe o que está fazendo. Quando a maioria dos tradutores ainda está engatinhando, está testando, faz o melhor que pode, mas não necessariamente o que deveria ser feito, ela não, ela faz tudo maravilhoso. Há também o exemplo de um livro do Bernard Cornwell, que é historiador. A história desse livro se passa na época em que Shakespeare estava escrevendo Romeu e Julieta e Sonhos de uma noite de verão. É claro que ele não usa palavras que vão atrapalhar a compreensão, mas é um inglês mais polido, mais rebuscado, um inglês que o leitor do original não usa no cotidiano. Ao encomendarmos a tradução desse livro, alertamos o tradutor que o objetivo era justamente proporcionar ao leitor brasileiro essa mesma experiência. Queríamos que o leitor da tradução tivesse uma experiência a mais próxima possível da que teve o leitor do texto original.

Lana: E em relação ao revisor, como é essa relação entre o tradutor e o revisor, eles têm contato durante a execução do trabalho, existe, na estrutura da Record, uma relação hierárquica entre um e outro, o que prepondera no produto final é a solução do tradutor ou a do revisor?

R.P.: Eu vou the dizer o que seria o ideal. O ideal seria tradutores como a Ivone Benedetti, por exemplo, que você tem certeza absoluta de que está sabendo o que está fazendo, então você respeita todas as escolhas, porque você sabe que todas as escolhas foram pensadas e repensadas. Ela sabe realmente o que está fazendo. Com isso, o copidesque vai ser aquela fase em que o profissional, o freela, vai fazer o cotejo do original com o português pra tentar identificar alguma pouca coisa que tenha passado, talvez falha ou algo que poderia ser melhorado. Nesse caso, todas as mudanças sugeridas vão voltar pra ela aprovar ou não. A mesma coisa aconteceria no caso da revisão. Isso seria o ideal e por quê? O tradutor é o que ganha mais no processo todo editorial, desde a tradução até o livro impresso, dos colaboradores externos, a remuneração do tradutor é bem maior do que a dos outros. É o nome do tradutor que sai assinando a tradução. Não faz sentido que 
seja diferente disso. Esse é o mundo ideal. Na prática, quando a gente não tem uma Ivone Benedetti ou outros tradutores que são assim acima de qualquer suspeita, e a gente tem uma oferta grande de livros e a gente precisa ter os livros todos traduzidos e você acaba tentando encontrar alguém que seja bom para aquele livro, mas que não é tão bom quanto uma Ivone Benedetti acontece de... Isso é uma opinião minha; nada do que eu estou dizendo aqui reflete a opinião da editora; é uma opinião pessoal - o que acontece dali pra baixo são pessoas que até podem ser boas, mas não são quase perfeitas, que cometem alguns erros de compreensão. Quando são poucos os erros de compreensão, quando são poucos os erros de salto, etc, você vai fazendo o cotejo e só corrige porque você identificou que ali tem um erro, está errado mesmo, você tem certeza e você vai e corrige. Não necessariamente que precisaria de aprovação. Depois que você acaba o copidesque todo, eu gosto de mandar para o tradutor para que ele aprove essas correções. Até porque isso pode ajudar o tradutor a melhorar o seu trabalho. Só que, algumas vezes, quando chega uma tradução em que a gente vê uma quantidade de erros de compreensão muito grande por parte do tradutor e isso acontece muito mais do que você imagina, você perde a confiança no profissional, você não quer nem dar satisfação, você quer corrigir tudo e nunca mais passar trabalho pra ele, o que eu não gosto. Essa é a nossa primeira reação e é uma reação natural, porque, pra você fazer o livro ficar bom, você teve que refazer praticamente todo o trabalho, cotejando frase a frase, perdendo um tempo fazendo uma coisa que não era pra você fazer. O que às vezes eu faço - e aconteceu recentemente um caso desse - em que veio a tradução e eu tive de fazer linha a linha e corrigi muitos erros, mas, mesmo assim, eu quis dar uma segunda chance à pessoa, porque eu vi que a pessoa tinha potencial. Eu peguei o arquivo e fiz o seguinte: peguei o arquivo de Word da tradução como me foi entregue e, depois, quando o livro já estava pronto para ir pra gráfica, eu peguei o arquivo do design onde foi feita a diagramação e colei no Word. Com dois documentos de Word lado a lado, você tem aquela ferramenta de fazer uma comparação automática. Quando gerou o terceiro arquivo com as diferenças entre um e outro, eu peguei esse arquivo e salvei com outro nome e mandei para a tradutor e falei "Olha... ela já estava com outro livro começando... você vai olhar todas as alterações, tem muito erro de compreensão, tem muito erro de todo tipo até de digitação, onde era “mão" estava "mãe”. Isso pode ser assim até o fim. Você vai olhar todos eles e vai me garantir que, no próximo, não vai ter nenhum erro de nenhum... nenhum não, porque eu sei que todo mundo é humano, mas, com aquela quantidade, não dá mais. Se o próximo vier assim, eu vou ver que não tem jeito, vou dizer pra ela estudar, praticar e, quando ela se sentir mais confiante de fazer um trabalho bom, daqui a alguns anos, aí a gente vai recebê-la de portas abertas. Mas isso dá um trabalho muito grande pra gente.

Lana: Esse tipo de coisa pode comprometer o cronograma de vocês, não é?

R.P.: Ah, compromete... 
Lana: E o que a Record entende por “boa tradução”? Sei que você responderá por você mesma, mas, de qualquer forma, você representa a empresa.

R.P.: O que eu digo pra todo tradutor é o seguinte: vamos dividir entre alta literatura e livro comercial, um best seller. Vamos falar primeiro do best seller. Ele tem que ser capaz de... primeiro, fazer com que a imagem gerada na cabeça do leitor brasileiro seja a mesma gerada na cabeça do leitor estrangeiro. Então, se numa frase o leitor inglês leu aquela frase e criou uma imagem daquilo, o leitor em português deverá ser capaz de criar aquela mesma imagem. Então... às vezes eu falava assim: pega a frase do inglês, lê a frase do inglês, entende, faz a sua imagem mental, entende o que ela quis dizer, o que ela quis informar ou comunicar, esquece o inglês e diz aquela mesma coisa em português de forma que você faça com que o leitor brasileiro crie aquela mesma imagem, seguindo a estrutura do original quando possível e não seguindo quando não for possível. A tradução, às vezes, é uma adaptação do original em que, no caso do livro bestseller, o conteúdo é mais importante do que a forma. Então, o que ele vai comunicar é mais importante do que a forma como ele comunica. Se ele não tiver nenhuma pretensão literária, esse é o meu objetivo. É isso que eu falo para as pessoas. É claro que você vai, o máximo possível, respeitar as escolhas de linguagem do original, do autor, você vai respeitar o máximo do autor que você puder. Mas, quando você vir que esse respeito está fazendo com que a fluência do texto em português não fique tão boa, que a experiência da leitura do original, em relação ao português, não está tão boa, você tem que fazer alguma coisa para que ela fique. Porque a reação do leitor àquela leitura tem que despertar a mesma ansiedade do thriller, o medo, não sei o quê. Um texto truncado com uma linguagem que não flua bem, com diálogos que sejam travados, etc, eles vão acabar gerando uma experiência de leitura inferior à do original. Com livros literários, aí é outro assunto. Aí você tem que respeitar o ritmo, você tem que respeitar toda a parte da forma, todas as imagens, todas as metáforas, adaptar só quando extremamente necessário para a compreensão de uma forma que respeite... É uma outra categoria de tradução. A maior parte dos livros aqui é comercial, da minha editoria. Então, na maior parte das vezes, a minha briga com os tradutores é para que eles não sejam tão literais, não respeitem demais as estruturas, porque, quando transportam para o português sem ser de uma forma muito eficaz, elas travam o texto, fazem com que a experiência de leitura não seja tão... O desempenho do livro lá fora pode ser muito bom, mas se a tradução não ficar tão bem resolvida quanto o texto original, ele pode ser avaliado como um livro ruim e isso afeta as vendas

Lana: E em relação a elementos paratextuais, é comum um tradutor fazer algum prefácio ou isso varia de acordo com a categoria literária...

R.P.: Desde que voltei pra Record, isso só aconteceu uma vez. Foi com o Demian, do Ivo Barroso, porque o Ivo Barroso é um nome. Essa inciativa de fazer a revisão da tradução de Demian partiu dele. Ele traduziu o Demian do alemão há 
muitos anos e, depois que ele foi aprendendo mais alemão, ele foi percebendo que ele tinha traduzido umas coisas que ele sentiu necessidade de corrigir. Ele é que sugeriu que nós fizéssemos a revisão da tradução. Ele revisou tudo e, para essa nova edição, ele escreveu um prefácio, assinou, um projeto assim quase que ... eu não digo autoral, mas era muito pessoal. Era uma história dele. Mas não é uma prática daqui, não. Talvez um texto de orelha ou algo assim, mas... só em casos muito particulares, em que a tradução vai ter um valor igual ou quase igual ao do autor, quando há influência do tradutor, quando a escolha daquele tradutor vai ser determinante para que as pessoas queiram ler o livro não só por causa do autor, mas também por causa do tradutor...

Lana: Como se fosse um selo de qualidade, de fidedignidade... Entendi. E em relação à escolha do título? O título é o cartão de visita do livro assim como a capa. Vocês enfrentam muito problema com isso, vocês adaptam, vocês dão preferência a uma tradução mais literal, vocês adicionam subtítulo, é uma jogada comercial...

R.P.: Uma das coisas que os livreiros levam em consideração - e eu vou lhe dar um exemplo muito interessante - na hora de supor, de tentar imaginar se um livro vai vender ou não, são duas coisas: o título e a capa. Em geral, a gente tenta fazer uma tradução o mais próximo do original. Quando não fica forte pelo lado comercial, a gente vê se existe alguma alternativa. E o exemplo que eu vou te dar é... a primeira alteração do título nem foi feita aqui. Foi feita do alemão para o inglês e a gente ainda fez uma alteração extra do inglês para o português. Em alemão é Das lasvendelzimmer, que significa "O quarto lavanda”. Quando foram vendidos os direitos para os E.U., o editor lá leu a história e viu que "O quarto lavanda” não ia vender nada com esse título e, pela história, resolveu fazer um título muito eficaz e funcionou muito bem pra eles que foi The Little Paris Bookshop, que era a história de um livreiro que o livro dele era um marco em Paris. The Little Paris Bookshop. Quando eu comprei os direitos da tradução, que eu fui tentar ver como poderia ficar o título em português, A pequena livraria de Paris me pareceu fraco. Aí eu fiquei fazendo um exercício... como no livro tem uns elementos "mágicos", porque esse livreiro tem o poder de olhar pra você e perceber os problemas pelos quais você está passando e sugerir o livro certo pra você e não querer vender um outro que vá fazer mal a você. E é uma intuição, uma habilidade que ele tem que é meio mágica. Aí eu botei A livraria mágica de Paris. E está em todas as livrarias, todos os livreiros... a história é muito linda, mas eu tenho certeza de que a nossa capa... a capa que a gente fez ficou mágica, ficou romântica, o título é bom. Com isso, você aumenta as chances de o livro chegar a mais pessoas, porque o primeiro cliente de toda editora é o livreiro. Se você consegue que o comprador da livraria fique empolgado com o livro, ele vai fazer um pedido de exemplares grande, vai fazer uma colocação nas lojas dele grande, o livro vai ter mais visibilidade, vai ter mais chance de mais gente saber que ele existe e querer comprar. É por isso que o título e a capa ajudam muito. Esse é o feedback que eles nos dão. 
Lana: Em relação à capa, qual é o perfil de leitor brasileiro que faz com que uma capa seja mudada, por exemplo, o que faz com que a capa da versão traduzida seja completamente diferente da capa da versão original?

R.P.: Isso é uma coisa que varia de editora para editora e varia muito do feeling do editor. Ele olha para aquilo e acha que não vai funcionar. Eu vou te dar um outro exemplo do que... em geral, a gente gosta de ter o feedback dos compradores das livrarias, porque eles estão lá na ponta e eles estão vendo o que está chamando a atenção das pessoas na loja. Deve estar chegando agora às livrarias, é $O$ menino feito de blocos. O título original é A Boy Made of Blocks. Eu achei que a capa original, que é inglesa, parecia, remetia um pouco para talvez um livro infanto-juvenil. Como o livro é para o público adulto, eu pensei "Vai que na Inglaterra funciona bem isso, mas aqui não sei, porque o jovem que se interessar por essa capa vai achar que é um livro pra ele, quando não é. Vai acabar comunicando para o público errado.". Aí eu comentando aqui dentro, eu pedi para a designer aqui da Record pra fazer uma versão, que também tinha ilustrações, mas me pareceu mais adequada. Quando chegou a época em que o nosso diretor comercial foi apresentar os próximos livros, ele levou a capara que a gente tinha feito aqui e o feedback do pessoal das livrarias foi exatamente aquele que eu estava tentando evitar. Aí eles falaram "Ah, mas isso aí está parecendo mais livro infanto-juvenil”. Aí eu falei assim: “O que a gente faz?”, porque já estava ficando meio em cima, o livro já estava perto de ir para a gráfica. Aí o diretor comercial falou assim: "E como é que estão as capas de outros países?”. Aí eu disse que mandaria para ele naquele momento os arquivos com as capas de todos os países para ele levar para os livreiros. Todos preferiram a capa da Inglaterra, aquela que eu tinha achado que talvez não fosse funcionar aqui. Com esse feedback, a gente comprou os direitos de usar a imagem do UK e foi essa que a gente usou. A gente só trocou o título em inglês pelo em português, tinha uma frasezinha em cima assim que a gente traduziu e mais nada. Varia muito. Eu gosto muito de usar a capa original, mas, de país pra país, o estilo de capa muda muito. Por exemplo, Daniele Steel, que é uma grande autora de livros comerciais, uma grande autora de best-sellers nos E.U e na Inglaterra... e os dois países de língua inglesa, nos E.U, as capas dos livros dela seguem uma estética e na Inglaterra, é uma estética diferente. Tem uma identidade visual de coleção “entre aspas”, mas são dois estilos. Um funciona bem para o gosto do público inglês e o outro funciona bem para o gosto do público americano. Não sei nem se do público ou do editor. Imagino que mais do editor. É uma questão meio subjetiva, eu acho. Se você me perguntasse essa mesma coisa na década de 90, eu talvez respondesse de forma diferente. O que faz com que hoje seja interessante aproveitar a capa do original sempre que possível é o fato de que as pessoas estão sabendo da existência do livro com aquela capa com antecedência pela internet, pelas redes sociais. Elas já criam uma identificação que eu imagino que, se elas ficam interessadas naquele livro com aquela capa quando ele sai no original, possa ajudá-las a achar na livraria aqui: "Ah, esse é aquele livro que eu queria comprar e que já está traduzido”. Mas muitos dos meus colegas preferem fazer capas originais e não aproveitar (a da versão original). "Ah porque a nossa capa vai ficar muito mais 
bonita”. Não que eu necessariamente concorde. Há casos em que, sim (a melhor opção é fazer uma capa para a versão traduzida). Por exemplo, neste ano a gente teve um livro chamado Distância de resgate, que, em espanhol, é Distancia de rescate. A capa do original não... eu pensei assim "Meu Deus! Não dá nem pra entender”. Foi lançado na Espanha. "Gente, que estranha essa capa! Não faz o menor sentido!”. Eu não estava conseguindo entender a capa. Aí eu passei o livro para a designer, a mesma designer ler e ela também é ilustradora. Ela fez uma capa tão linda e que tem tudo a ver. Quando olha de primeira, você não identifica, você não entende direito, mas, depois que você lê, você entende. A capa é linda, linda, linda. Às vezes, a gente... Não tem uma regra.

Lana: E em relação ao cronograma que vocês estabelecem? Já aconteceu de o lançamento do original e o da tradução terem sido simultâneos?

R.P: Neste ano aconteceu um caso. Eu achei importante que a gente lançasse junto, mas acabou que não deu certo em vendas, não. Aqui no Brasil... isso é uma observação dos últimos anos... eu vejo que o livro já sai com um potencial maior de vendas quando o livro lá fora já começou a fazer sucesso e as pessoas aqui se espelham muito. Elas buscam o que está o que está funcionando lá fora. É talvez um boca a boca, um modismo, o que está fazendo sucesso lá fora eu tenho que ler...

Lana: É a cultura hegemônica.

R.P.: Exatamente. Então, não funciona muito bem. Eu estou revendo essa estratégia para esse ano para afastar um pouquinho, nem que seja por três meses. Por exemplo, em A garota no trem, ele foi contratado tipo um mês antes de entrar na Record. E não estava traduzido nem nada, nós passamos para a tradução, trabalhou nele, mas ele estava com uma tradução problemática. Quando chegou da tradução... eu não vou falar quem foi, mas está lá no livro, né? Era uma autora da Record que, por algum motivo, as pessoas acharam que ela poderia traduzir. Era autora, escrevia bem e passaram pra ela.

Lana: Reescrita é uma coisa e escrita é outra.

R.P.: Aí a gente tinha programado por causa dessa tradução problemática para lançar no fim do ano, até pra dar tempo de fazer o trabalho com calma. Só que começou a bombar muito lá fora e as pessoas começaram a comprar pra ler em inglês. Aí o pessoal do comercial atento a essa movimentação falou: "Olha, tem que lançar logo.”. Isso foi no início do ano, tipo março mais ou menos. Aí eu peguei para eu fazer. Fiquei umas duas semanas até de noite, cotejando linha a linha, corrigindo tudo e a gente conseguiu lançar em agosto. Foi em torno de um semestre, mas o suficiente para criar um buzz tão grande que, quando ele chegou aqui, as pessoas já estavam ansiosas pela chegada dele. Foi o mais vendido de agosto do ano passado até agora. E agora, com o filme, melhorou mais ainda. Acho que, se você der uma distância... Acho que tem que analisar caso a caso, porque tem muito livro que as pessoas compram direto do inglês, dependendo, por 
exemplo, se for místico... por exemplo, se foi livro destinado ao público nerd, você sabe que o público nerd vai ler o original e outros casos, não. Por exemplo, tem uma autora... eu acabei de receber o "ok" da oferta dela, que já foi publicado na década de 90, mas nunca foi publicado aqui. É um gênero que está fazendo muito sucesso hoje, mas que as pessoas que gostam desse gênero não fazem distinção se o livro é novo ou se é antigo, que é o romance histórico, daqueles "hot”, do tipo “o duque que pegou a...”.

Lana: Algo do tipo Ligações perigosas?

R.P.: Coisas sexy, porque a gente também tem os romances históricos, como os da Phillipa Gregory, que são mais fiéis à história mesmo. Eles chamam agora de "romance de época”. Então eu estou feliz porque a gente... Então, (para esse público), não faz diferença quanto tempo já saiu lá, a distância... Só acho que lançar simultâneo pode atrapalhar.

Lana: E aqui vocês têm algum levantamento estatístico de línguas... quais as línguas mais traduzidas? É o inglês ainda, não é? E é seguido por quais outras?

R.P.: Francês e espanhol acho que na mesma medida e depois o alemão.

Lana: Italiano lá embaixo, né?

R.P.: Lá embaixo... e agora com a morte do Umberto Eco então...

Lana: Ah, é verdade. Ele era o...

R.P.:... o autor. Na minha editoria, eu tenho inglês, francês... tem o caso dos nórdicos que a gente não consegue encontrar tradutores muito bons dessas línguas norueguês, sueco, finlandês etc... e que às vezes, por contrato, pede a tradução para o inglês. Inclusive, tem um caso curioso que é do John Nesbø que, antes de eu entrar para a Record, os livros dele eram traduzidos por uma norueguesa. E aí vinha tudo truncado, uma coisa horrível e o pessoal ficava se matando para o trabalho ficar bom e era sempre aquilo meio Frankenstein. Aí, o John Nesbø veio ao Brasil e a gente estava na Livraria Argumento e, quando a gente parou para tomar um café, e ele perguntou pela tradutora e eu falei que era uma norueguesa. Ele ficou passado. "Como assim é uma norueguesa que traduz para o português. E fica bom?”. Aí eu falei, "Ficar perfeito não fica na hora que chega dela, mas a gente faz ficar perfeito”. Aí ele... "Não! Vocês têm que traduzir os meus livros do inglês, porque não só vai ficar mais fácil de vocês acharem tradutor para traduzir do inglês, como os meus livros ficam melhores em inglês”. Quando o livro é publicado originalmente, ele segue um cronograma que, em geral, é pressionado por tempo e tudo o que você faz pressionado por tempo sai com erro. Quando 
você faz tradução... na tradução, você consegue encontrar todas as falhas do original e essas falhas do original são corrigidas para a edição em inglês. E aí, lá pela segunda ou terceira edição norueguesa, elas são incorporadas, mas a edição em inglês é mais bem-feita do que a do original. Isso nas palavras do próprio autor.

Lana: Então, quer dizer que a tradução melhora o original e as melhorias feitas ao longo do processo tradutório vão ser incorporadas nas edições futuras do original.

R.P.: Tem uma história muito engraçada de quando eu estava traduzindo $A n$ Abundance of Katherines, do John Green, que ficou em português $O$ teorema Katherine, ele é um livro infantojuvenil e o passatempo favorito do protagonista é fazer anagramas e anagrama você não traduz. Anagrama você adapta. Foi muito divertido. Eu adorei fazer...

Lana: É um quebra-cabeça, né?

R.P.: Foi muito legal. Eu fiquei dias e dias fazendo aquilo, mas foi maravilhoso. Só que num processo que eu imagino que a edição original tenha sido feita a toque de caixa e é uma coisa mais ou menos complexa. Em algumas partes do livro, o cara era um gênio, um prodígio, e fazia coisas do tipo memorizar todos os 99 mil dígitos de $\Pi$ (pi). Pra fazer isso, ele criou uma frase em que cada palavra começava com a letra equivalente em posição no alfabeto ao algarismo da sequência. Aí eu falei "Bom, vamos lá, vou tentar manter um pouco do sentido porque, no original, era uma nonsense, mas que fazia algum sentido. Aí, eu peguei uma planilha de Excel botei em cada linha uma palavra, confirmei com um matemático do INPA (Instituto de Ciência, Tecnologia, Inovações e Comunicações) os números do $\Pi$ pra ter certeza que eu estava trabalhando com o número certo e eu botei do lado o algarismo na sequência, traduzi a palavra pra ter a equivalência do que tinha sido escrito no original e depois tentei, com o que eu havia entendido, criar uma nova frase que contivesse algum sentido do original, mas que cada palavra começasse com a letra certa. Nesse processo, eu descobri que duas das palavras estavam com a equivalência errada dos números e que, na verdade, não tinha 99, tinha cem. Aí, na época, eu falava direto com o John Green, mandava email pra ele. Aí ele ficou chocado. Eu mandei essa e mais uma planilha de Excel com mais 30 erros, porque a pessoa, quando está lendo, não vai conferir. Você só descobre essas coisas quando está traduzindo. Esse foi o exemplo mais complexo, mas há outros mais simples que você também não pega. Aí eu mandei todas as correções com cópia para a editora do original para que eles corrigissem na próxima edição.

Lana: Há pouco, Renata, você mencionou “manuscrito”. O que vem a ser o manuscrito de uma obra? 
R. Pettengill: Hoje funciona assim, tanto no país de origem do autor quanto no mercado internacional: o autor acaba de escrever o livro, uma primeira versão, lá no computador dele, arquivo Word. É a primeira versão, não editada, bruta, que ele envia para os agentes literários, que fazem uma seleção. Estou falando de um autor iniciante, porque, com autores consagrados, a coisa é um pouco diferente. Ele acaba de escrever o livro e manda para vários agentes literários para saber qual vai se interessar pela obra dele e vai querer representá-lo. Aí um deles gosta do livro e aquele agente literário responde, dizendo que gostou do livro e se oferece para representá-lo. Aí, a partir da assinatura de um contrato, aquele agente literário vai tentar vender o livro para uma editora ou editoras, no país de origem e/ou no exterior. As editoras vão ler e ver se aquele livro segue a linha editorial adotada, no caso de haver mais de uma interessada, vai a leilão. Por exemplo, um autor inglês com representação de um agente literário inglês para várias editoras inglesas, sendo que os direitos de publicação foram para língua inglesa, mas não comprou os direitos para o mundo. Pode ser que uma outra agência literária entre nessa negociação, mas para vender os direitos para o mercado externo. Esse processo pode ser dividido em etapas. Pode acontecer de o livro estar sendo apresentado dentro do seu país de origem e, ao mesmo tempo, para o resto do mundo. Pode acontecer de a compra dos direitos para a publicação no exterior anteceder à compra dos direitos para a publicação no país de origem. Nesse caso, a primeira versão que se lê no mundo ser a primeira versão do livro, o manuscrito. Como a quantidade de livros novos oferecidos no mercado é enorme, a gente não consegue ler tudo. Aí a gente entra em contato com os scouts, que fazem uma triagem dos títulos que estão surgindo no mercado.

Lana: E quanto à escolha do tradutor? Por exemplo, esse livro que mencionamos, A mulher do meu marido, como vocês chegaram ao tradutor dele?

R. Pettengill: Quem poderia fazer melhor aquela tradução, quem tem mais conhecimento e experiência naquele assunto, quem demonstrou ser mais capaz de pesquisar mais, independente do assunto. No caso do livro do Cornwell, que é um outro exemplo, como se estava falando de Shakespeare, achei que seria importante que o tradutor conhecesse essa literatura, mesmo não sendo primordial que ele soubesse traduzir poesia shakespeariana propriamente. Foi por isso que pedi indicação para a Prof ${ }^{a}$ Marcia Martins, sua orientadora, que me passou o contato do José Roberto O’Shea.

Lana: A propósito desse livro sobre Shakespeare, você disse que o texto original tem um paladar de época, é sempre opção da editora preservar esse paladar?

R.Pettengill: O caso do Cornwell, que é historiador, o livro se passa na época em que Shakespeare estava escrevendo Sonhos de uma noite de verão e Romeu e Julieta. É claro que ele não usa palavras que vão atrapalhar a compreensão, mas é um inglês mais polido, mais rebuscado, um inglês que o leitor do original não usa 
no cotidiano. Ao encomendarmos a tradução desse livro, alertamos o tradutor que o objetivo era justamente proporcionar ao leitor brasileiro essa mesma experiência. Queríamos que o leitor da tradução tivesse uma experiência a mais próxima possível da que teve o leitor do texto original.

Lana: E quanto ao revisor, como a editora delimita a divisão de searas entre tradutores e revisores?

R. Pettengill: O copidesque é o profissional que faz o trabalho de cotejamento. Ele lê linha a linha, original e tradução para saber se o texto traduzido para o português diz exatamente o que diz o original. Por exemplo, no caso de um tradutor novato, inexperiente, nós alertamos o copy para redobrar a atenção. Depois de conferida a tradução, o texto volta para nós para sabermos se nós aceitamos as emendas feitas por ele. Isto feito, o texto traduzido vai para uma segunda revisão, esta feita pelo revisor, que vai ter por objeto de observação o texto conferido pelo copidesque. O revisor não tem a obrigação de aferir a tradução. É de sua responsabilidade observar eventuais erros de ortografia, pontuação, às vezes, o emprego de uma ou outra palavra, mas não em relação à tradução em si. Ele só recorre ao original num caso de dúvida mesmo. Essa é a segunda revisão de paginada, que é para ver se há alguma coisa que não está fluindo bem em português. Delimitando claramente o objetivo da primeira revisão de paginada (сору) e da segunda (revisão), agiliza-se o trabalho. Essa segunda revisão de paginada é o pente fino que se passa no texto traduzido. Depois que sai do copy, o texto traduzido e, agora, copidescado, vai para o revisor com as emendas feitas pelo profissional do copidesque. O revisor da segunda paginada só vai nas emendas, diferente do copy, que lê o texto todo, cotejando original e tradução. Só se fazem emendas nessa segunda etapa, se for um caso de erro crasso, alguma frase truncada, alguma coisa que tenha passado pelo copy. No caso de um tradutor iniciante, com pouca experiência no ofício, para garantir um texto traduzido com boa qualidade, submetemos a tradução a uma terceira revisão de paginada.

Lana: Pelo que entendi, essa “cadeia de revisão” depende muito de uma tradução benfeita. Quanto melhor a tradução, menos emendas. É isso?

R. Pettengill: Sim, mas sempre haverá emendas, porque tanto a tradução quanto as duas etapas de revisão (copy e revisão propriamente dita) são feitas por pessoas e a escolha das palavras é uma coisa pessoal.

Lana: Você disse que o serviço de copidesque consiste no cotejamento entre original e tradução, com o objetivo de verificar se a tradução foi feita corretamente, ou seja, se o texto traduzido possui o mesmo conteúdo do original. 
Partindo dessa premissa, entendo que se espera do profissional do copy uma habilidade tradutória, por assim dizer. É isso?

R. Pettengill: Sim, mas são atividades diferentes. O copy não produz a tradução; o tradutor, sim. Às vezes, acontece de o copy também ser tradutor, e isso o faz se sentir compelido a mudar o que o tradutor escreveu. Muitas vezes, nesse caso, troca-se o seis por meia dúzia. Acontecia isso comigo, quando eu traduzia. Às vezes, eu levava dias para achar aquela palavra adequada, que mais cabia na frase, e o copy vinha e mudava. Dava muita raiva.

Lana: Existe, então, essa "cadeia de revisão" que lapida muito bem o texto, com cada profissional com suas funções muito claramente definidas. Isso dispensa um contato entre tradutores e revisores?

R. Pettengill: O ideal é devolver o texto ao tradutor para que ele veja o que foi modificado. É importante que o tradutor tenha a humildade de entender que, no momento em que ele está fazendo a tradução, muitas vezes, não lhe ocorre a melhor solução para uma palavra, um termo. Muitas vezes, é preciso um olhar externo para encontrar aquela palavra, aquele termo que caberá melhor ali, naquela frase, que vai tornar o texto mais natural em português. Observo que há uma geração (de tradutores), mais jovem, que acha que sabe tudo. São prepotentes, não tem a menor modéstia. $O$ inverso também pode ocorrer: o tradutor sabe que o texto será revisado e, durante a tradução, não se dá ao trabalho de pesquisar, de procurar a melhor opção para aquela palavra.

Lana: Você saberia dizer se essa geração tem formação em tradução?

R. Pettengill: Não. Ninguém trabalhando em editora tem formação em tradução mesmo. A maioria tem formação em Comunicação Social, em Letras, mas não especificamente em tradução. Quando eu entrei na Record, em 1990, eu tinha 20 anos e só tinha o segundo grau. Ninguém que trabalhava comigo tinha formação acadêmica em Letras ou algum treinamento em tradução. Havia as gramáticas, os dicionários, muita vontade de trabalhar, de aprender com quem já fazia isso há mais tempo e, sobretudo, humildade. Havia um senhor que trabalhou com a gente aqui por um bom tempo, chegou a se aposentar, mas voltou a trabalhar na editora. Ele só parou de trabalhar mesmo quando fez 70 anos. Ele também não tinha faculdade, mas era de uma dedicação exemplar! Era um pesquisador e um leitor incansável! Para mim, não é o fim do mundo a pessoa não ter nível universitário. O mais importante é ter paixão pela leitura, pelo universo dos livros, e ter a humildade, a consciência de que ninguém sabe tudo.

Lana: Renata, os tradutores e os revisores não possuem vínculo empregatício com a editora, certo? 
R. Pettengill: Não. São todos freelancers: tradutores, copidesques e revisores. A Record mantém uma equipe de copidesques aqui, trabalhando in loco, cuja chefe é a Gloria, com um expediente de seis horas.

Lana: Renata, agora fale um pouco de você, um pouco da sua experiência como editora, a sua formação.

R. Pettengill: Eu fazia Letras na UERJ e Ciências Sociais na UFRJ, mas as coisas ficaram difíceis lá em casa e eu precisei acumular estudo e trabalho. Só que eu não queria trabalhar em qualquer coisa. Eu queria trabalhar em alguma coisa que me proporcionasse prazer. Comecei a olhar enlouquecidamente os classificados dos jornais até que, um dia, eu vi um anúncio “cargo de revisor”. Aí eu fui à agência de empregos que estava contratando e disse aquela coisa clássica "Não tenho experiência, mas preciso da oportunidade do primeiro emprego”. Aí, a psicóloga que estava me entrevistando me perguntou se eu sabia os sinais de revisão. Eu respondi que não, mas, se ela me indicasse um livro que tivesse os sinais, eu compraria, estudaria e voltaria no dia seguinte sabendo todos eles. E assim aconteceu. Ela me deu o nome do livro, saí de lá, passei numa livraria e comprei o livro. Cheguei em casa e devorei o livro. No dia seguinte, voltei e provei que eu tinha estudado e aprendido os sinais. Ela ficou impressionada com a minha atitude. Ela me disse que tinha gostado da minha aura. Só que a editora estava precisando de alguém com experiência realmente e contrataram um cara que preenchia esse requisito. Aí aconteceu que, uns dois ou três meses depois, um revisor aqui da Record, muito religioso, estava se sentindo incomodado com o volume de obras cujo conteúdo o agrediam na sua fé, na sua postura de vida, enfim. Ele acabou pedindo demissão. Aí, a psicóloga se lembrou de mim e me chamou. Aí, eu comecei a trabalhar na Record e fazendo duas faculdades. Por problemas de horário, precisei trancar a UERJ e prossegui na UFRJ. Tive também uma passagem pela UFF, em jornalismo, mas tranquei em 1997, quando casei. Assim, academicamente, sou formada em Ciências Sociais. Eu estava trabalhando aqui já havia um bom tempo não só revisando, mas fazendo outras coisas, como copy, sempre procurando aprender mais. Eu queria traduzir também, mas eu sentia que não era capaz de traduzir sem uma formação acadêmica. Foi quando eu fiz a especialização na PUC e, depois disso, comecei a traduzir uma coisinha ou outra. A questão é que, para acumular as minhas funções aqui e as traduções, só me restavam as noites e os fins de semana. Fiquei um tempo longe da Record. Isso foi em 1998. Saí daqui e fui para o Reader’s Digest, que publicava matérias só para assinantes da revista Seleções. Fiquei 16 anos lá. Apesar de eu fazer lá o mesmo que eu faço aqui, as propostas editorias são diferentes. Lá o público é fechado e garantido. São os assinantes da revista. 
Lana: Qual é exatamente a diferença, Renata?

R. Pettengill: Lá na Reader’s Digest eu trabalhava mais com não ficção, com matéria jornalística, mas lá também tem uma linha de ficção. Aí eu pedi para trabalhar com essa linha, porque eu estava com saudade. A diferença é que o alcance do seu trabalho na Reader's Digest é menor, pois o público é direcionado, limita-se aos assinantes. Assim, a editora não participa de feira literária, FLIP, BIENAL, de evento nenhum que envolva o mercado editorial. Era um universo meio paralelo. Por outro lado, era ótimo, pois o salário é maior do que em outros lugares, pois é uma multinacional. Só que não havia desafio.

Lana: Navegando pelo site da sua linha editorial, eu vi que há umas republicações de clássicos e best-sellers. São retraduções?

R. Pettengill: Depende. Se for uma tradução datada, há a necessidade de se revisar e fazer um texto mais atual, mais contemporâneo. Nós temos uma equipe aqui de editores que fazem uma triagem.

Lana: Você falou dos scouts e dos agentes literários. São duas profissões, duas atividades que não se confundem, certo?

R. Pettengill: O scout é estrangeiro e contratado por uma editora de outro país. Quando ele vê que há no país dele um projeto que ele imagina que vai agradar àquele país, àquela cultura, aí ele entra em contato e apresenta o livro. O agente literário faz uma curadoria dos títulos e recebe um valor fixo. Ele manda um catálogo do que existe no mercado exterior. Diferente do scout, o agente literário não faz juízo de valor dos livros que ele apresenta. Ele é um prestador de serviço. O scout seleciona os livros que lê e faz um report para mandar para o agente literário que vende os livros com base nos reports do scout. Na verdade, o agente literário é um vendedor.

Lana: O que é um bom tradutor para a Record?

R. Pettengill: O bom tradutor é aquele que dá menos trabalho pra gente. E o que é dar menos trabalho? É quando o tradutor faz uma tradução que proporciona ao copy e ao revisor uma leitura mais prazerosa. E o que é dar trabalho? Por exemplo, no texto há uma palavra que tem uma série de acepções, mas ele escolhe logo a primeira que aparece, sem pesquisar, sem procurar entender o que está dito no original. Quando o texto vem para o copy, de cara se percebe que o tradutor não pesquisou, não dedicou tempo para encontrar a palavra mais adequada. Aí, o copidesque terá que fazer o trabalho dele. Quanto mais ocorrências dessas houver, mais marcações o copy terá que fazer e, consequentemente, mais tempo o revisor terá que dedicar àquela revisão. E isso atrasa o cronograma. Aí, na hora de escolher entre um tradutor que dá trabalho e um que não dá trabalho, escolho o 
segundo, claro. Muitas vezes, eu tento me colocar no lugar daquele tradutor que dá trabalho, pois quero ajudá-lo a aprimorar o seu trabalho, mas, dependendo da situação, o que vai pesar é a fluidez do trabalho em equipe. Se eu tenho tempo e recursos financeiros para continuar insistindo nessa pessoa, eu insisto. Se não, opto pelo que não dá trabalho. Eu costumo dizer que pessoas com TOC são bemvindas (rs). As pessoas com Transtorno Obsessivo Compulsivo são excelentes tradutores, pois tem obsessão pela correção e desconfiam de tudo. Assim, saem em busca da melhor solução.

Lana: As equipes de tradutores e revisores se mantêm com certa regularidade? Há a admissão de novos profissionais ou não?

R. Pettengill: Antigamente era mais comum a admissão de novo profissionais. A gente só deixa de traduzir com um tradutor que, muito solicitado, muito consagrado no mercado, passa a cobrar valores que a editora não pode pagar.

Lana: Por falar nisso, Renata, qual é a política de valores da editora? Negocia-se com o tradutor, cada profissional é um preço, como é?

R. Pettengill: Aqui na Record é sempre tabela. Isso é uma determinação da direção da empresa. Nós estávamos com um livro aqui que pensei na Denise Bottman para traduzir. Aí eu mandei uma mensagem privada pra ela no Facebook e perguntei o valor. Agradeci, mas não havia a menor possibilidade de pagar o que ela cobra. Alguns tradutores, que por serem muito cobiçados, só trabalham com as editoras que bancam os valores que eles cobram, mas são casos isolados.

Lana: Durante o almoço, você estava falando de alguma coisa que me interessou muito. O que foi mesmo?

R. Pettengill: Foi a respeito de título. Deixe eu pegar um exemplo muito bom. Esse livro aqui, Tudo aquilo que nos separa, da Rosie Walsh. Os direitos foram vendidos ao mesmo tempo para os Estados Unidos e para a Inglaterra, dois países de língua inglesa. O título da versão americana é Ghosted, que quer dizer algo como "dar um perdido", quer dizer, aquela pessoa que, depois de um tempo saindo com você, some sem deixar rastros. Só que, na Inglaterra, o livro se chamou The Man Who Didn't Call. É a história de uma mulher que conheceu um cara e criou toda uma expectativa de ele ter se apaixonado por ela com a mesma intensidade com que ela se apaixonou por ele. Só que há uma série de desencontros e o decisivo para separá-los foi arquitetado pela mãe dele, a megera da história. Aí, quando o livro chegou para nós, resolvemos fazer um brainstorming para chegar a um título bom no português do Brasil. Fomos para uma sala de reunião e eu contei a história do livro. Depois disso, as mulheres começaram a falar todas ao mesmo tempo, uma em cima da outra, e aí, de repente, o Bruno, que tinha ficado calado a reunião inteira, sugeriu Tudo aquilo que nos separa. Todo mundo ficou em silêncio, que só quebrado pela salva de palmas que 
fizemos para ele! Aí, no mês de janeiro, se não deste ano, o do ano passado, eu estava de férias, em Portugal, quando recebi um email da agente literária me convidando para participar de um strategy day no escritório de Londres com a autora do livro. Como eu estava relativamente perto, resolvi ir. Comuniquei à editora de que abrira mão de um dia das minhas férias para participar do encontro. Estavam todos os editores da Europa. Cada um foi apresentando o título que o livro recebeu no seu país como se fosse um plano de marketing. O nosso título foi o que mais saía da caixa. Todos os outros giravam em torno do título original, da ideia de alguém que sumiu, que não deu mais notícias, que não deixou rastro. Comercial e linguisticamente falando, era um título possível em inglês: All that keeps us apart. Se a reunião tivesse acontecido antes dos lançamentos nos países, esse poderia ter sido o título do livro no mundo todo. Quem identifica essa pegada comercial é o editor e o agente literário. A questão é que os leitores brasileiros de tradução se apegam aos títulos em inglês. Hoje em dia, há os blogs de leitores, tão poderosos no mercado editorial no momento, e nós pedimos o feedback desses blogueiros para escolhermos o melhor caminho. Outro componente comercial importante, além do título, é a capa. Vou lhe dar um exemplo. A capa deste romance de época aqui foi especialmente criada para remeter a uma história de época, com esta moldura dourada, circundando esta figura. Aí aconteceu de as vendas serem surpreendentes, não só por toda a estratégia de marketing, mas a capa teve um peso considerável. E que acontece? As editoras veem o movimento do mercado e tentam pegar carona numas coisas pra ver se tem o mesmo sucesso. A editora Planeta entrou em contato com a Renata Vidal, a designer dessa capa, e a chamou para fazer a capa para um lançamento deles. Só que esse tipo de capa, esse tipo de layout é para romances de época. Há toda uma gama de elementos plásticos que rementem a uma história que se passa em tempos distantes. E as leitoras têm esse olhar crítico, elas percebem, captam isso muito bem. Só que, na hora de passar o briefing para a Renata, a Planeta só insistiu na questão do layout, insistiu para que a deles fosse bem similar à da capa do nosso romance de época. A capa, apesar de muito benfeita, nada tinha a ver com o gênero de romance, que não era de época. O erro foi da editora, que passou o briefing errado. Aí, num blog de leitoras, o Notas Literárias, foi criada uma hashtag, acho que “\#MudaotituloPlaneta”, ou algo assim. Essa questão do feedback, hoje em dia, é muito intensa, mas, antigamente, não. Eu me lembro que, uma vez, entrevistei o autor inglês Neil Gaiman e toquei nesse assunto, o da interação com o leitor, e ele disse que raramente recebia email de leitores brasileiros, mas que se lembrava de uma vez só. Citando o exemplo, eu disse que tinha sido eu. Foi a tradução de uma palavra num livro infantil dele que ficou muito ruim. Aí, você chega à conclusão de que ou as traduções para o português do Brasil são maravilhosas ou o leitor brasileiro não é nada crítico.

Lana: Talvez pela visão que o leitor tenha de que a editora é uma instituição "superior" e fique acanhado de criticar. Talvez se sinta intimidado por ser ele uma pessoa criticando algo maior. 
R. Pettengill: Pode ser isso, sim. Essas traduções que eu chamo de “macarrônicas” são muito comuns nos livros infanto-juvenis. Acho que tanto os tradutores desse gênero quanto as editoras têm a certeza de que o leitor, jovem, não perceberá a tradução ruim e, assim, não vão se manifestar. O tradutor é visto como alguém "superior" e o leitor mediano não se sente à vontade para apontar falhas, talvez por achar que o tradutor ("superior") não comete erros, mesmo sentindo que "há alguma coisa estranha no texto". 


\section{ANEXO H \\ Entrevista com Silvia Leitão, ex-editora do Grupo Editorial Record (06 de setembro de 2018)}

Lana: Silvia, fale um pouquinho da sua experiência como editora, da sua formação profissional.

S. L.: Sou formada em Comunicação Social pela UFRJ e, na época, eram três habilitações: jornalismo, publicidade e produção editorial. Eu optei por produção editorial e gostei muito desde o início. Ainda no curso de graduação, tive a oportunidade de fazer um estágio e foi nessa oportunidade que me encantei. Era exatamente o que eu pensava e um pouco mais. Foi aí que eu tive a oportunidade de ter acesso aos originais, ao trabalho de texto, tornar aquele texto adequado ao público, como pensar numa capa, como pensar no público a que se destina aquele livro, se está bem adequado, padronizado. Foi encantadora essa experiência.

Lana: Então, você, como editora, teve a oportunidade de acompanhar e de participar de todo o processo que eu investigo.

S. L: Exatamente. Desde a aquisição do título, que é a obra. Os agentes literários enviam para os editores (uma lista de títulos) e os editores encomendam. Há várias possibilidades de um título chegar a uma editora: através do agente literário, entrando em contato com o próprio autor, que pode ser um especialista no assunto e fazer a encomenda do livro, pode receber por correio, por email. Há também os scouts, que são agentes especializados, que moram fora do Brasil e agem como se fossem olheiros. Estão sempre antenados com as novas tendências, com os autores que estão despontando. Hoje em dia, os autores não precisam das casas editoriais para publicarem seus livros. Existe o que se chama de autopublicação, que é feita nos meios digitais, numa Amazon, por exemplo. Dependendo do sucesso que o livro tenha, o autor acaba migrando para as editoras convencionais.

Lana: Você poderia falar sobre os três selos que estiveram sob sua responsabilidade, o Best Bolso, o Viva-Livros e o Best Business? Quando foram criados, qual é o público que cada um almeja, que tipo de produto (considerando todos os aspectos envolvidos, do texto à capa) é oferecido por essas marcas?

S. L. Os três selos fazem parte do Grupo Record. No Best Bolso publicamos os livros clássicos em formato bolso: antologias, textos de domínio público e que estão fora de catálogo. O Best Business é mais voltado para negócios e administração. Já o Viva Livros, assim como o Best Bolso, também um selo de bolso, mas voltado para religião, motivação, saúde. Os tradutores precisam ter afinidade com a área. Tanto na Best Bolso quanto na Viva Livros temos um percentual de $80 \%$ de traduções. A maioria dos livros lançados pelo Best Business 
é de livros estrangeiros, cerca de $70 \%$ escritos em inglês e os $30 \%$ restantes, de autores brasileiros. Fizemos uma tradução do alemão, mas usamos o original em inglês para tirar dúvidas e fazer cotejo. No Best Bolso, o ranking de línguas é mais diversificado, pois, em se tratando de clássicos, além das em inglês, temos obras em alemão e francês. Há ainda os inéditos, recentemente preparamos uma coletânea com quinze aventuras do personagem Sherlock Holmes. É um livro paradidático, voltado para o público infanto-juvenil. Outras editoras também lançam coletâneas de textos de domínio público, mas o que é exclusivo é a seleção dos textos que compõem essas coletâneas. Cada editora faz a sua seleção. Nós fizemos a seleção de acordo com a faixa etária do público alvo: nono ano do Ensino Fundamental. Fazemos a tradução do texto na íntegra. Quanto à tradução, ela é exclusiva para uso da editora, porque o tradutor assina um contrato de cessão de direitos autorais. Por exemplo, o tradutor dessa coletânea das aventuras do Sherlock foi nosso funcionário aqui e já sabíamos que ele era fã do Sherlock e conhecia bem a linguagem. Nesse caso de textos que serão usados como textos paradidáticos, procuramos contemplar tradutores jovens, pois haverá uma identificação maior entre o texto traduzido por esse tradutor e o público jovem a que essa coletânea se destina. No caso desse tradutor, ele foi funcionário aqui da casa e migrou para colaborador externo. Eu esperei ele terminar duas traduções que estavam em andamento para poder pegar a nossa, porque sabia que viria um texto bom. Mesmo reunindo essas qualidades, a de ser fã de Sherlock, a de ser jovem e de fazer um trabalho que já conhecíamos, pedi para que ele fizesse um teste com os capítulos iniciais e, só então, ele deu sequência ao trabalho. Esses da Best Bolso são os livros clássicos, cultura contemporânea também, mas são obras já conhecidas e que, em algum momento, foram publicadas pela casa. No caso dos livros de negócios, nós temos uma tradutora que é formada em economia e ela é a minha preferida, porque, quando o livro vai pra ela, não preciso pagar revisão técnica. Todo o know-how corriqueiro da área ela domina. Por exemplo, há um livro em produção em que aparecem muitas vezes as palavras coaching e mentoring. Coaching é usual e nem precisa vir em itálico, porque já foi absorvido pelo português, mas mentoring, que é o trabalho do mentor, é pouco usual. Acho que não vamos colocar em itálico porque vai ficar graficamente feio, pois o termo aparece no livro todo. O certo, num primeiro momento, seria grafar em itálico, mas estamos reavaliando essa questão. Tanto a tradutora como nós da editora começamos a pesquisar e vimos que esse termo já está sendo bem usado no meio corporativo.

Lana: Considerando esses três selos, você afirmaria que há três perfis diferentes de tradutor, um para cada uma dessas marcas? Em caso afirmativo, como você descreveria cada um desses perfis de tradutor? Há casos de tradutores que traduzem para dois desses selos ou mesmo para os três?

S. L.: São três perfis diferentes de tradutor conforme o perfil de cada linha editorial. $\mathrm{Na}$ verdade, existe o tradutor técnico e existe o não técnico. Essa primeira categoria, de maneira geral, é o tradutor de livros acadêmicos. Traduzem 
livros de medicina, de direito. Esses são os tradutores técnicos. Há os tradutores juramentados, que fazem tradução de contrato, de documentos, e os tradutores literários, que traduzem ficção e não ficção. Em geral, o tradutor literário traduz obra de entretenimento. Essa "não ficção” a que eu me refiro são biografias.

Lana: Como esses tradutores são escolhidos? Eles passam por algum tipo de teste? Em caso afirmativo, esse teste tem por objetivo apenas aferir a qualidade como tradutor, ou seja, a qualidade do tradutor se reflete tão-somente no produto que ele confecciona ou há algum tipo de entrevista pessoal, em que outras qualidades são observadas? Em caso afirmativo, que qualidades são essas?

S. L.: Há um quadro de colaboradores externos e cada um faz bem um tipo de tradução. Tais colaboradores fazem bem biografias, por exemplo, outros fazem bem ficção, outros fazem bem não ficção. Quando entra em produção um título novo e ficamos em dúvida pra quem passar, pedimos os testes. Pedimos um capítulo para avaliar e, quando é bem aceito, quando a linguagem está boa, o tradutor dá continuidade ao trabalho. Passa por duas ou três pessoas da equipe interna, cotejando com o original e uma terceira lê só o texto traduzido. Há os revisores externos também. Geralmente, um tradutor que traduz bem ficção dificilmente é bom na tradução de não ficção. Existem perfis. O histórico de outros livros que o tradutor já tenha traduzido é um bom termômetro para o editor decidir. Quando o editor tem muita dúvida, passa dois capítulos e pede para o tradutor fazer a título de teste antes de dar o livro todo. Isso é muito comum quando o assunto do livro é muito específico. Ocorreu recentemente com uma obra que é sobre o universo da série Game of Thrones, mas é uma obra de não ficção. A autora, que é professora de literatura inglesa, resolveu pegar todas as obras da série Crônicas de gelo e fogo, de autoria de George Martin e que deu origem à série, e comparar com a adaptação para a televisão. O assunto do texto é literatura, mas o texto em si é um texto acadêmico. Aí, a editora optou por buscar a tradutora que fez todas as traduções das obras do George Martin no Brasil por conhecer a terminologia. Foi um caso à parte, porque a tradutora, embora seja tradutora de ficção, foi a mais indicada para traduzir uma obra de não ficção por conhecer o tema e a terminologia. Isso foi decisivo para a escolha da tradutora. Só que, no geral, isso não ocorre, porque são linguagens diferentes. A não ficção é mais próxima à linguagem jornalística. A da ficção é mais romanceada.

Lana: E os revisores? Como são escolhidos? Os critérios para a seleção de tradutores e revisores variam de selo para selo ou há um conjunto de critérios adotados pelo grupo editorial? É exigida dele uma habilidade tradutória? Afinal, ele está revisando uma tradução. À semelhança do que ocorre com o tradutor, há tipos de revisor?

S. L.: Já há uma equipe fixa de revisores que, assim como os tradutores, são colaboradores externos. A maior parte da produção textual é feita fora do âmbito da editora, para agilizar o trabalho, mas eventualmente nós, da equipe interna, 
fazemos uma leitura, um cotejo. O ideal é que ele tenha, pelo menos, um conhecimento mediano do idioma do qual a obra foi traduzida para saber se tem alguma coisa estranha ali. Aí, a partir da marcação do revisor, vamos ver se foi um erro de tradução, se é um problema em língua portuguesa. Tem a revisão que se faz logo após a tradução, que é a preparação de originais, que algumas editoras denominam copidesque. Hoje em dia, usa-se mais "preparação de originais", que é o cotejamento entre original e tradução, que é feito ainda no Word, e tem a leitura de prova após a diagramação. Aí o livro já está diagramado e a leitura é feita no papel.

Lana: Na condição de editora, você prefere trabalhar com tradutores já conhecidos pela empresa ou você acha que arriscar um tradutor novo pode ser positivo, pois oxigenar a equipe é sempre desejável?

S. L. : Uma situação que me ocorre agora foi a de 2007, quando a Editora Record fez uma associação com a canadense Harlequin Books, uma editora que lança livros que são vendidos em bancas, livros femininos produzidos em série, como periódicos. A canadense montou um escritório aqui dentro da empresa. Como a distribuição era feita em banca de jornal, não podia falhar. Era que nem jornal, revista. Aí, precisou-se formar um grupo de tradutores e havia uma especificidade que era a seguinte: a edição original em inglês tinha 288 páginas, por exemplo, então a edição traduzida tinha que ter o mesmo tamanho, 288 páginas. Só que na tradução em geral o livro ganha em torno de 20 a 30\% de volume, a tendência é a versão traduzida do inglês para o português ter mais páginas. Foi preciso então formar duas equipes, uma de tradutores e outra de "condensadores", que eram tradutores hábeis em "enxugar texto”. E que enxugamento era esse? Esses livros eram muito vendidos no interior para um público formado por mulheres jovens, literatura de entretenimento, geralmente tinham um casal na trama, havia umas histórias mais picantes, outras menos picantes, mas, em geral, eram livros com texto de fácil leitura. Eram histórias com personagens que se repetiam. A gente até brincava internamente: "Essa é a série do sheik, essa é a série do comandante”. As personagens eram mocinhas que sonhavam com uma vida bacana. Pelo perfil (gênero literário), eram textos com muitos adjetivos, muito detalhe, muitos trechos descritivos e esses condensadores iam direto nesses adjetivos e nessas descrições. Para dar conta do prazo imposto pela periodicidade da distribuição, formou-se um mutirão. Era uma equipe de 30 tradutores, trabalhando home office. Essa associação Record-Harlequin durou 8 anos, e deu oportunidade de trabalho para muitos tradutores.

Lana: Em algum momento do processo de confecção do texto traduzido (a tradução propriamente dita e a sua consequente revisão) tradutor e revisor mantêm contato? 
S. L.: Terminada a tradução, o tradutor entrega para o editor, que, por sua vez, entrega para o copidesque. O que é de bom tom se fazer? O editor manda o texto na íntegra depois de passar pelo copidesque ou uma prova diagramada para o tradutor ver o que foi modificado. Nessa cópia diagramada que o editor envia para o tradutor, aparecem marcadas as alterações feitas pelo copidesque. Então o tradutor dará o “OK” (ou não) para o prosseguimento ao trabalho. Esse processo de reenviar a tradução para o tradutor não é obrigatório, mas é de bom tom fazer. O copidesque revisa a tradução em si, coteja com o original e tem mais liberdade de ajustes. Já a revisão que se faz na prova diagramada não tem o intuito de examinar a tradução em si, embora sempre é bom enviar o original. A finalidade desse último estágio de revisão é de verificar o volume de texto, ou seja, se houve omissão de palavra, frase ou até mesmo parágrafo.

Lana: Nos selos sob sua responsabilidade, já houve algum projeto em que a tradução precisou ser dividida por uma equipe de tradutores? Em caso afirmativo, como se deu esse processo? O mesmo se aplica à revisão dessa tradução dividida?

S. L.: Acontece, por exemplo, de a pessoa adoecer ou pode até surgir alguma fatalidade, então a tradução passa para outro tradutor. Neste caso, os créditos são dados aos dois tradutores, se o primeiro chegou a entregar alguma parte, os nomes dos dois aparecem na folha de rosto. Pode até ser mais específico: tradutor tal até tal capítulo e tradutor tal do capítulo tal em diante, mas isso é raro. Sendo dois tradutores, ao final do trabalho há que se fazer uma revisão minuciosa para se uniformizar, padronizar o texto traduzido.

Lana: No tocante às normas editoriais, são as mesmas para os três selos? Em caso negativo, o que difere os critérios que norteiam a confecção do texto traduzido editado por cada um desses três selos?

S. L.: As normas são gerais do Grupo Record: onde usar aspas, onde usar travessão, onde usar número arábico, palavras que devem ser grafadas em itálico. Isso é do Grupo. Por exemplo, dependendo do caso, num romance da década de 1920, há uma palavra que já caiu em desuso, mas não é recomendável que seja substituída. O tradutor pode fazer uma nota de rodapé. Um exemplo é de um livro sobre Nietzsche em que no original havia o termo "tartufice", que é uma referência ao personagem-título Tartufo, da peça de Molière. A nota de rodapé se fez necessária, mas a explicação poderia vir no texto, entre travessões, o que eu prefiro. O que menos gosto é quando a nota vem no fim do livro, porque o leitor precisa interromper a leitura para virar uma série de páginas para ter acesso àquela informação. Se for uma informação de até duas linhas que você possa colocar entre parênteses, entre travessões, é melhor. Se for uma explicação extensa, aí precisa vir em nota de rodapé mesmo. 
Lana: Ainda sobre as normas, tradutor e revisor podem negociar essas normas? Quais delas são inegociáveis?

S. L.: Podem, sim. O que acontece em termos de normas editoriais é que precisa haver uma padronização dentro do livro. As normas da editora são para o conjunto do catálogo. Por exemplo, um mesmo autor tem dez obras. Para as de número 1, 2, 3 e 4, as normas são essas, mas a 5, por alguma razão, requer uma flexibilização dessas normas. Se puder manter o mesmo padrão em todos os livros daquele autor, publicado pelo mesmo selo, melhor. Se não, dentro de um único livro é obrigatório ter um padrão.

Lana: A Record, na condição de editora, lida com um produto muito especial, pois não é um simples produto que possua uma finalidade imediatista, prosaica. É um produto cultural. No entanto, é um negócio que, como tal, implica risco. Assim sendo, que fatores concorrem para que a editora decida por publicar uma obra estrangeira a ser traduzida e uma obra de um autor brasileiro?

S. L.: No passado era muito comum você ter escritores consagrados fazendo tradução. Por exemplo, Lya Luft fazendo uma tradução de Hermann Hesse. É um nome. Você tem Rachel de Queiroz fazendo uma tradução da Emily Brontë. Se você consegue juntar no mesmo livro o peso do autor e o peso do tradutor, aí os dois nomes vão para capa: "Hermann Hesse com tradução de Lya Luft", "Emily Brontë com tradução de Rachel de Queiroz”. Sem dúvida, soma muito. E, numa decisão de publicar, a tradução a ser publicada é a da Raquel de Queiroz, que tomou a liberdade de reescrever vários trechos, do que a tradução da "Maria Serafim”. De um modo geral, as editoras investem em autores conhecidos. Ser conhecido é um critério. Entre um livro de um autor estrangeiro conhecido e um livro de autor brasileiro desconhecido, opta-se pelo primeiro, pois já há um histórico de vendas. Por exemplo, você vai tratar de vendas com a Saraiva, por exemplo, e oferece um lançamento de autor conhecido e um de um estreante. É um trabalho hercúleo o do departamento de marketing, imprensa, comercial. De um autor conhecido, ele vai encomendar um número significativo, enquanto que do estreante vai encomendar 10 exemplares, porque a livraria não vai empatar capital. Hoje em dia, a gente ainda usa muito a consignação, porque, para as livrarias, ocupar o espaço de uma prateleira tem um custo alto. Como dizia um colega nosso aqui, prateleira de livraria não é de borracha, não dá pra esticar. A empresa lida com um produto que sabe que vai girar e com outro que ela não sabe se vai girar. No caso do autor nacional, para valer a pena o investimento, ele precisa ser um acadêmico que circula nesse meio, precisa haver matérias jornalísticas sobre ele. Esse escritor precisa ser "autor-atleta”, que corre atrás, que vai promover a sua obra, mantém blog, investe na divulgação da sua obra. 
Lana: A Record possui os direitos autorais sobre algum autor brasileiro? Caso possua, há intenção por parte da empresa em negociá-los para tradução em outros países? Se essa venda se der, como será esse processo?

S. L.: Tem, sim. Tem alguns agentes que fazem essa ponte, mas, em geral, no exterior não se lê português. O próprio autor pode fazer a versão para a língua estrangeira ou a editora encomenda a tradução de alguns trechos, não do livro todo, claro, porque é um serviço muito caro. É versão, serviço mais caro do que a tradução. Há um autor conhecido que ele próprio bancou todo esse processo. Ele selecionou poucas editoras, umas três, mas eram editoras que ele sabia que se interessariam em publicar o livro dele. Ele levou mais de um ano alinhavando tudo, contratou a tradução, tudo por conta dele. Nesse cenário, a exceção é aquele nome que fez fama fora da literatura. Por exemplo, o Chico Buarque. Ele se consagrou na música e esse sucesso passou para a literatura. A gente chama de “autor-celebridade”. “Autor-celebridade” é muito mais fácil de a editora levar pra fora. Não sendo o "autor-celebridade”, por exemplo, pode ser o caso de um autor premiado. É um escritor que ganhou o Prêmio São Paulo de Literatura, que hoje tem tanto peso quanto o Jabuti. E o da Biblioteca Nacional também está ganhando muito espaço. Depois que o autor é premiado, o que a editora faz? Ela relança a obra premiada com capa nova em que figura essa informação. Então, a editora tenta vender o livro lá fora com essa nova capa, em que consta essa informação que agrega valor ao nome do escritor. Quais são os autores que conseguem ser publicados lá fora? Os “autores-celebridade”, que se consagraram em outras áreas e esse sucesso se transferiu para a sua carreira dentro da literatura, ou o "autorchancela”, que conquistou prêmios literários importantes. Às vezes, o autor que nem é celebridade e nem chancela, mas tem bons contatos no exterior que podem abrir portas, que já morou lá fora sei lá quanto tempo, então, pode conseguir, mas, em geral, são esses dois perfis.

Lana: E, por exemplo, um tradutor da casa, conceituado, não necessariamente famoso, mas respeitado, numa viagem ao exterior, se ele se deparar com um título interessante, ele pode sugerir à editora?

S. L.: Pode, sim. Se é um tema que é super atual lá fora e que não é conhecido aqui, mas é uma tendência. Vamos apostar? Vamos apostar. Então o título é levado ao departamento comercial, para avaliação, também se conversa com a diretoria e o editor usa os argumentos que comprovem que vale a pena apostar. Precisa pesquisar quem publica lá fora, quem é o proprietário, faz-se uma oferta, um contrato, pode-se passar para aquele tradutor. Esse tipo de sugestão parte de tradutor que já tem um relacionamento com a editora, que conhece a linha, que pesquisou aquele tema e aquela obra. A editora sabe de quem está partindo a sugestão. Não é um tiro no escuro. Não vai acontecer de a editora publicar um livro sugerido por alguém desconhecido que manda uma mensagem pelo serviço de atendimento ao cliente. 
Lana: Pelo que se observa, levar para seu estande numa feira de livros um autor conhecido, com um público leitor cativo, é um plus que as editoras, de um modo geral, oferecem aos seus leitores. Afinal, é ele a estrela da festa. No entanto, no caso de obras traduzidas, é o tradutor que possibilita essa leitura que atingiu o público alvo. A Record já pensou em reservar um espaço para que o tradutor se tornasse conhecido do público e com ele tivesse uma espécie de interação? Pelo que posso lembrar, nenhuma editora brasileira jamais fez isso. O que você pensa dessa ideia?

S. L.: Em geral o que acontece são mesas redondas, mesas de debate. Colocar o tradutor lá no estande, sem um evento que o contextualize e que vá atrair o público, não vai acontecer nada. Por exemplo, colocá-lo em um Café Literário, um espaço que tem uma agenda com vários debates, neste caso pode funcionar. O tradutor pode falar sobre produção textual, sobre temas ligados à área editorial. Tem que estar dentro de um contexto. Por exemplo, um debate sobre a produção do livro. O tradutor vai fazer parte dessa cadeia.

Lana: No tocante ao que, nos Estudos da Tradução, nós chamamos de "paratextos editoriais” (prefácio, posfácio, orelha, quarta capa), algum desses textos é redigido pelo tradutor?

S. L.: O prefácio, se a editora encomendar. Por exemplo, a Julia Romeu, tradutora do Mary Barton, da Elizabeth Gaskell, uma autora inglesa do século XIX, disse que o texto era tão rico em elementos históricos e culturais e perguntou se poderia fazer um prefácio ambientando o leitor. Essa questão do tradutor, de quem é o tradutor afeta no valor que se paga pela tradução. Há uma tabela de valores, mas aquele tradutor que agrega valor à obra, que a gente tem que entrar na fila para ter o texto traduzido por ele, o preço que a gente paga é negociado, pois vale a pena. A gente sabe que vem um texto bom que vai enriquecer muito o texto final.

Lana: E em relação à capa? A capa é o cartão de visitas do livro. Qual o cuidado que se tem na confecção da capa de um livro traduzido que não se tem na confecção da capa de um livro escrito originalmente em português? No caso de um livro traduzido, normalmente se repete a capa do original ou se produz uma capa nova? Entendo que título e capa andam muito juntos, não é?

S. L.: O primeiro passo é a escolha do título. Às vezes, se traduz o título ao pé da letra e não fica bem resolvido. O título é uma marca. Por isso precisa ser bem escolhido. A partir de um título bem escolhido poderão surgir outros produtos, pode até surgir uma coleção dali. Geralmente, o tradutor faz algumas sugestões, umas duas ou três, e, a partir dessas sugestões, chega-se a uma denominador comum. 
Lana: E a capa?

S. L.: O primeiro passo é a escolha do título. Escolhido o título, parte-se para a segunda etapa, que é a capa. Aí, pesquisam-se as capas estrangeiras daquela obra. Normalmente, as capas alemãs são as melhores, pois a Alemanha é o berço da imprensa, de Gutemberg, das artes gráficas, dos recursos gráficos. Então, eles têm uma noção de design muito boa. Em capas bem resolvidas, a gente pode usar o mesmo conceito, comprar o layout e adaptar para o Brasil. A grande decisão é: vai se reproduzir ou adaptar alguma capa estrangeira ou vai se fazer uma totalmente nova? A partir dessa decisão do editor, o capista faz o seu projeto de adaptação ou de $100 \%$ de criação.

Lana: E, ao longo da sua experiência como editora, quais os livros que mais the deram prazer de editorar? Os autores, os tradutores com os quais você gostou de trabalhar, os revisores... bem, os revisores têm uma importância diferente da do tradutor, não é?

S. L.: O tradutor é um criador, mas todas as etapas são importantes. Com relação aos livros, quanto mais trabalhoso, mais marcante ele é, mas, se, depois de todo o trabalho, ele fica bem finalizado, é bem recebido, aí não tem preço.

Lana: Agora você tocou num ponto importante: "quando o livro é bem recebido pelo leitor”. Qual é o termômetro que você tem dessa recepção?

S. L.: Hoje em dia, o leitor tem muito acesso para dar feedback. O SAC, que é o serviço de atendimento ao cliente, é um desses canais. Mandam mensagem dizendo que gostou ou não da capa, da própria tradução. "Olha, tal expressão foi traduzida 'assim', mas o correto é ‘assado'”.

Lana: Você tem conhecimento de algum título que tenha sido uma grande aposta e que acabou sendo um fracasso? Não precisa ter sido você a editora.

S. L.: Às vezes acontece de ser um livro de momento. Nesses casos, você tem que fazer o processo todo correndo, comprar o título correndo, traduzir correndo. Se você publicar dois meses depois do boom, já era. Acontece também de, lá fora, o livro ter sido um sucesso, pois teve um grande investimento por parte do autor, que participou de vários lançamentos, houve também um investimento no produto, por exemplo, um book trailer, que hoje se faz muito, entrevista... Aí, chega ao Brasil, faz-se um bom produto, lança-se com um bom preço, mas não há verba para fazer toda essa divulgação. Aí o produto não tem o mesmo sucesso que teve lá fora. 
Lana: Entendo que existe um fluxo mercadológico entre as editoras e o leitor em que as livrarias funcionam como um mediador. Como se dá a relação entre as editoras e as livrarias?

S. L.: Esse fluxo está mudando, né? As livrarias já não são mais os únicos canais de distribuição. Hoje temos sites como Mercado Livre, Lojas Americanas, o D2W, a própria Amazon, e o editor pode vender e disponibilizar lá no site e o leitor comprar direto. Não há mais o intermediário da livraria. 


\section{ANEXO I \\ Entrevista com a tradutora Raquel Zampil (14 de outubro de 2018)}

Lana: Fale um pouco sobre a sua experiência como tradutora, citando exemplos de traduções que fez para a Record e que foram marcantes por alguma razão.

R.Z.: Sou formada em Letras. Assim que saí do curso, fui trabalhar na Record com revisão. Trabalhei por um ano e meio, dois anos. Depois, fui fazer um curso nos Estados Unidos. Fiquei lá 9 meses, mas não interrompi o meu vínculo empregatício com a editora. Só fiz uma pausa, mas, logo que retornei para continuar a fazer revisão, imediatamente me puxaram para a editoria de bestsellers. Ao mesmo tempo, fiz um teste pra lá mesmo, para atuar como tradutora. Em 99\% das editoras, não vou dizer 100\%, porque sempre há uma exceção, o tradutor trabalha como freelancer. Como a minha carga horária diária na editoria era de 6 horas, eu tinha tempo livre para traduzir. Foi quando resolvi investir na minha carreira de tradutora. Descobri que eu adorava o trabalho e me inscrevi na graduação de formação de tradutores. Eu já trabalhava como tradutora, mas sentia falta de teoria. Bem, acho que estou colocando a carroça na frente dos bois. Deixe eu ordenar as etapas. Primeiro fui para o editorial; ao mesmo tempo, comecei a traduzir e fiquei uns dois ou três anos acumulando as duas funções. Só que eu gosto de estudar e sentia a necessidade de aprender um pouco de teoria. Muito embora o trabalho de tradução seja essencialmente prático, ou seja, quanto mais você faz, mais você se aprimora, eu sentia falta de conversar com as pessoas sobre uma teoria, conhecer mais gente que atuasse na área e manter com elas encontros regulares. Aí cursei um semestre da graduação. A Marcia foi uma das professoras que me sugeriram que eu fosse direto para a pós. Foi então que troquei a graduação pela especialização. Continuei traduzindo para a Record até que, em 1996 ou 97, eu decidi que queria só traduzir. Não queria mais fazer as duas coisas, editoria e tradução. Então, saí da Record e vim pra cá (Readers’ Digest), e fiquei uns dois anos só traduzindo para a revista (Seleções). Depois recebi uma proposta da revista para atuar como editora, uma proposta bem interessante. Como era um trabalho fulltime, pensei comigo "Não vou mais traduzir", porque queria me dedicar à editoria. Só que eu não aguentei ficar longe da tradução. Comecei a pegar uma coisinha aqui, outra ali... Inclusive, voltei à tradução a conselho de um amigo, que sabia que eu gostava de traduzir, que me disse para não sair do mercado. "Deixe um pezinho lá, porque, senão, as pessoas vão se esquecer de você". Eu tive a sorte de já estar inserida no mercado, porque eu sei que não é fácil você conseguir entrar. Na Record, o primeiro trabalho de tradução que fiz foi sobre meditação. Fiz uns dois ou três livros de autoajuda até eu pegar o meu primeiro livro de ficção, meu primeiro romance, que é o que amo fazer. Na verdade, eu fazia de tudo um pouco, mas $80 \%$ eram ficção e alguma outra coisa de não ficção. Quando eu tive a minha primeira filha, comecei a me interessar por literatura infantil. Descobri, então, que não era aquela bobagenzinha que eu achava até então. Eu me interessei tanto por literatura infanto-juvenil que fui fazer um curso de pós sobre o assunto na UFF. A partir daí, passei a traduzir basicamente literatura infanto-juvenil. Traduzi bastante para a linha editorial Galera, da Record, e para a Editora Intrínseca também na linha infanto-juvenil. O que ocorreu foi que eu era editora-assistente aqui na revista. Quando o meu chefe saiu, assumi o lugar dele e acabei por diminuir bastante a minha produção como 
tradutora. Antigamente, no caso de um livro de trezentas páginas, por exemplo, você tinha em torno de três meses para entregar para a editora a versão traduzida. Hoje, com a globalização, com as redes sociais, o leitor passou a ter mais acesso às editoras e, inclusive, seguem os autores como se fossem pop stars. Com isso, passam a exigir o lançamento quase que simultâneo de original e tradução, o que aumenta a pressão no tocante ao fator prazo. Isso também contribuiu para a diminuição da minha produção como tradutora, porque não tenho toda essa disponibilidade. Tenho muito trabalho na revista. Hoje só consigo traduzir livros que ofereçam um prazo maior. Essa pressão de tempo eu senti bastante no selo Galera, da Record. Por exemplo, se um livro é lançado no país de origem agora, daqui a dois meses não se fala mais nele lá. Aí, não faz mais sentido traduzi-lo. Se você entrar na página da editora, vai ver a gurizada cobrando "Olha, eu quero ler o livro tal”. Traduzi os três últimos livros da série Percy Jackson e recebi mensagem de muitos leitores, que viram o meu nome na ficha. Ficavam me cobrando quando sairia o próximo e eu tinha de explicar que essa questão era com a editora. Com as redes sociais, hoje em dia, o tradutor deixou de ser aquela figura de bastidores. Essa procura por contato com o tradutor é muito mais frequente por parte do público jovem. Eu tive essa experiência por causa da séria Percy Jackson. Também traduzi a série que deu origem à animação Como treinar seu dragão ${ }^{126}$. A série é composta por onze livros e a autora escreveu um por ano, ou seja, ela dedicou onze anos da vida dela para produzir a série. É muito interessante observar que os primeiros livros são bem leves e os últimos são marcados por uma atmosfera bem sombria. Identifiquei um amadurecimento dela como escritora que se refletiu no texto. Eu me apaixono por todos as traduções que eu faço. É muito difícil eleger uma. Mesmo que seja um romance “água com açúcar”, a leitura mais completa de um livro é a leitura do tradutor, porque é a leitura que não deixa passar nenhum detalhe. O tradutor pensa em tudo: no vocabulário, na estrutura dos períodos, nas frases, nos termos e elementos que podem ter duplo sentido, nas frases que não estão muito claras. Então, você dedica muito tempo para esmiuçar todos aqueles pedacinhos. Por isso, na minha opinião, é uma leitura completa mesmo. Não é a única leitura ou a leitura mais precisa, mas é uma leitura atenta, que para em cada pedacinho. Mesmo aquele texto mais simples requer do tradutor uma leitura muito atenta. Às vezes, como leitora, eu não compraria aquele livro que eu estou traduzindo, mas, ao longo do processo, acabo descobrindo algo interessante, um personagem, um jeito de apresentar aquele enredo. Acho que nunca houve um livro que, ao final da tradução, eu tenha dito “Graças a Deus!”. Não, nunca.

Lana: Quais são as maiores dificuldades - dentre as de natureza linguística e as de natureza cultural - para se traduzir um texto?

R.Z: As de natureza cultural, sem dúvida. O principal, na minha opinião, para um tradutor, além do conhecimento muito bom da língua de origem, é, sobretudo, o conhecimento da língua alvo, que tem que ser ainda maior. Hoje em dia, você tem tantos recursos, porque, se você é um leitor atento, tem um

\footnotetext{
${ }^{126}$ Série homônima, de Cressilda Cowell
} 
“desconfiômetro”... É porque eu, como atuo como editora também, às vezes vejo umas traduções e me pergunto “Como a pessoa não desconfiou disso aqui?”. Aí recorro ao original e vejo que também não conheço aquela estrutura, aquele termo, mas está na cara que não é o que está na tradução. É porque o tradutor não pesquisou. Hoje em dia existem muitos recursos. Além de contar com todo tipo de dicionário online, pode-se tentar contato com especialistas que conhecem o jargão ali empregado. Uma vez, traduzi um livro que era a história de um jóquei. Então, entrei em contato com cavaleiros para saber detalhes. Muitas vezes, você vê uma palavra conhecida, mas que, naquele contexto ali, tem outro sentido. Então, o tradutor tem que ter essa percepção. Além de o fator cultural ser muito importante, o tradutor precisa ser movido pela curiosidade, tem que ler, pesquisar, informarse. Se você começar a falar sobre alergia, vou ficar ligada, porque, um dia, aquela informação poderá ser importante. Agora, existem traduções que exigem muita criatividade por parte do tradutor. Por exemplo, no caso de haver no original neologismos criados a partir de elementos lexicais da língua fonte, terei que recriar na língua alvo esses termos inexistentes. Essa questão ainda é mais capciosa quando se trata de uma série, pois aqueles termos que estão sendo recriados na tradução estarão presentes nos outros livros. É um fator muito importante para o tradutor decidir sozinho. Num caso como esse, o que eu faço? Mando para o editor uma lista de sugestões, pois, muitas vezes, conseguimos criar mais de uma opção para o mesmo termo do texto fonte. Muitas vezes também, nenhuma das opções satisfaz plenamente o tradutor, mas é o que ele conseguiu recriar. No entanto, a decisão final de usar ou não os termos criados pelo tradutor é do editor. Existem também palavras e termos de duplo sentido, frases que rimam. No momento, estou traduzindo um romance para a Record que apresenta uma dificuldade. O título original é The songs of us e é o primeiro romance da autora, Emma Cooper, que é inglesa. É a história de uma mulher, cujo marido desaparece, e que tem dois filhos ainda pequenos. Num determinado momento, ela leva um tombo, bate com a cabeça, fica desacordada e uma sequela provém desse acidente: ela passa a ter uma compulsão por cantar em qualquer situação em que ela esteja. Por exemplo, se ela está aqui conosco e qualquer uma de nós diz uma palavra que a remeta a uma música, ela começa a cantar a tal canção sem conseguir se conter. E qual é a dificuldade aí especificamente? É que, em inglês, a coisa flui naturalmente, porque as canções foram originalmente compostas em inglês, com letras em inglês, ou seja, a palavra que detona o processo mental e comportamental da personagem é em língua inglesa e a música se encaixa no texto. E qual é o recurso que estou usando? Mantenho o verso em inglês, original, e depois coloco a tradução, porque não posso mudar a letra da música. Comuniquei à Renata sobre essa minha estratégia e depois eles lá veem se é isso que eles querem. Há uma cena interessante em que ela está na fila do supermercado e percebe que o nome da caixa é Sue. Aí ela se lembra de uma música, que, aliás, eu não conhecia. É uma música country americana que conta a história de um garoto a quem o pai deu o nome de Sue, que é um nome feminino. O pai abandona a mãe, quando ele ainda é criança. Para se defender do bullying que sofria por ter nome de mulher, ele precisou se tornar agressivo. No fim, ele encontra o pai num bar. Eles têm uma briga violenta, mas, por algum motivo, o pai o reconhece. Então, ele diz ao filho que ele tem que lhe agradecer pelo fato de lhe ter dado um nome de mulher, pois foi isso que o fez "forte". A personagem do livro começa a cantar essa música para a caixa do supermercado e a moça se sente 
ofendida e tal. Bem, esse não é um texto que o tradutor pegue para traduzir com tranquilidade, sem parar para remover obstáculos. Tem que parar, pensar, pesquisar. A questão também é que eu não sei se o leitor conhecerá todas as músicas ali usadas como referência. Há algumas bem conhecidas, como uma dos Beatles, por exemplo, mas há muitas desconhecidas também. Se a Record mantiver a minha sugestão de ter original e tradução no texto, o leitor curioso vai pesquisar no YouTube, por exemplo.

Lana: Depois de traduzido, o texto vai para a revisão. Você tem acesso às alterações que o revisor faz à sua tradução? Existe algum contato entre tradutor e revisor? Esse contato seria desejável?

R.Z.: São raríssimos os casos. Sempre me coloco à disposição do revisor. Também já fiz copy e tinha vontade de perguntar "Por que o tradutor escolheu esse termo?”. Sei que o profissional não é leviano, que deve ter pesquisado esse termo. Antes de escolher a palavra, ele pesou prós e contras. Agora, não há esse contato direto entre tradutor e revisor. Agora, como tradutora, no texto do email em que encaminho ao editor o arquivo com a versão traduzida, sempre informo os meus contatos para o caso de o copy querer tirar dúvida. A Renata, por exemplo, é uma editora super aberta nesse aspecto. Não aconteceu comigo, mas aconteceu com uma amiga minha que traduz pra ela. A própria Renata colocou as duas em contato. Era uma tradução com prazo apertadíssimo, em que a tradutora traduzia um capítulo e mandava para o copy. Acho que a maioria das editoras pode fornecer ao tradutor a versão copidescada, se o tradutor pedir. Agora, tem o seguinte: nesse caso, o máximo que pode ocorrer é o tradutor tentar defender uma escolha sua importante, um termo que tenha dado trabalho para achar, porque, na verdade, a tradução é uma cessão de direitos. A partir do momento em que você entrega o texto traduzido para o editor, ele deixa de ser seu e passa a ser da editora. A troca de termos escolhidos pelo tradutor feita pelo copy é uma questão subjetiva, mas, uma vez, numa tradução minha, o copy substituiu o certo pelo errado. Foi um caso de colocação de pronome átono, quando, na frase, havia um "não”, que puxa o pronome (próclise). Aí fui olhar no meu arquivo e estava certo, com o pronome proclítico, como devia ser. Nesse caso, foi o copy que mudou equivocadamente para a posição de ênclise. Isso eu acho péssimo.

Lana: A classe dos tradutores literários, em sua grande maioria pelo menos, se não na sua totalidade, é composta de freelancers. Como você vê essa condição? Seria interessante para o tradutor ter vínculo com as editoras?

R.Z.: Agora, vou dar a minha opinião contaminada pela minha visão de editora também. Não funcionaria o tradutor como funcionário, não o tradutor de ficção. Existem as firmas de localização de software que contratam tanto freela quanto aquele que vai todo dia e cumpre horário. Só que é um caso de tradução mais mecânica, que tem aqueles recursos como o Trados, por exemplo, que já guarda os termos usados no assunto ali. Por exemplo, o revisor de texto literário traduzido é contratado e tem expediente a cumprir, mas é um trabalho mais rápido. E qual é o problema de você ter um tradutor literário como contratado, que 
tenha carga horária diária para cumprir? Há dias em que o tradutor não está a fim de traduzir. Eu digo por mim. Há dias em que acordo empolgadíssima, traduzo até sábado à noite, porque estou ali envolvida. Impor ao tradutor o cumprimento de um expediente das 9 às 17, por exemplo, não funciona porque o profissional não vai dar o seu melhor. Ele vai ser obrigado a sentar lá e traduzir durante aquele tempo. A tradução não é uma atividade à qual você se obrigue. Não estou dizendo que a tradução não seja um trabalho e que o tradutor não tenha compromisso. Tem e cumpre prazos, mas, por exemplo, estou aqui preocupada com a nota do meu filho e preciso resolver isso primeiro. Não vou conseguir me concentrar no texto. Aí, resolvido esse problema, compenso num outro momento traduzindo o dia inteiro. Tem dias em que o tradutor está uma máquina de trabalhar, mas, em outro, não. Vejo isso como uma vantagem.

Lana: Como é, na sua experiência, o processo de escolha do tradutor para um determinado livro? Na Record há espaço para o tradutor propor a tradução de um título para a editora?

R.Z. Tenho, sim. Aliás, espaço para falar com o editor todo mundo tem, mas não existe muita oportunidade pra isso. Por quê? As editoras grandes já trabalham com uma rede de scouts, agentes literários, que já fazem isso. Dificilmente, vou chegar lá com um livro que identifique como a cara da Record e que a Renata, por exemplo, já não conheça. Eles sabem muito antes do que qualquer um.

Lana: Na sua visão, até que ponto o tradutor é responsável por uma tradução publicada, considerando a atuação de outros profissionais (agentes), como o editor e os diferentes tipos de revisor?

R.Z.: Aí vai ser uma relação de confiança entre o tradutor e o editor. Por exemplo, eu, na condição de editora, e você, tradutora. Você me entrega a sua tradução. Só haverá alteração no seu texto, se for uma coisa muito importante. Não vou trocar seis por meia dúzia. Mesmo que seja um errinho que me incomode, se for uma coisa boba, não será modificada. Porque é chato, quando a revisão substitui o certo pelo errado. Aí, você pega o livro já no mercado e vê um erro que não foi você que cometeu. Por exemplo, no caso de um neologismo, como eu falei antes, e a editora achar que não ficou bom. Aí, provavelmente, vão me ligar para me comunicar que vão mudar a minha sugestão para uma outra, que a editora julgou que seria melhor. Independentemente de eu concordar ou não, é a escolha da editora que vai prevalecer, mas, pelo menos, sou comunicada antecipadamente da troca. 
Lana: O que é tradução para você? E qual o papel do tradutor?

R.Z.: É a clássica: a ponte que liga dois mundos que não falam a mesma língua. Eu vejo como esse canal mesmo. Agora, considerando a tradução como um tipo de leitura, eu diria que é a leitura mais completa de um texto. Eu, como leitora e tradutora, vejo que estou numa posição privilegiada de poder fazer essa leitura. Como leitora apenas, não vou ter a oportunidade de esmiuçar como tradutora. Fora essa visão da tradução como leitura completa, é esse canal. Ao traduzir, vou levar a obra para um universo que não teria a oportunidade de lê-la. Mesmo aquele leitor que pode ler na língua de origem, às vezes, por alguma razão, pode optar por ler a versão traduzida. A tradução tem um alcance maior, claro, dentre os leitores que não dominam a língua fonte. Agora, comparando original e tradução, eu diria que o livro traduzido não "espelha" o texto de origem, porque não existem correspondentes perfeitos entre duas línguas diferentes. A tradução é o mais próximo do texto fonte que o tradutor conseguiu produzir na língua alvo. Estou longe de saber ao certo o que o autor quis dizer, mas foi o mais próximo que pude chegar do texto daquele autor. O tradutor, por sua vez, é quem promove esse canal. Ele vai captar o que ele entendeu daquele texto estrangeiro e passar para as outras pessoas. É um papel muito, muito importante, porque, sem ele, eu não poderia leu um livro escrito em russo, por exemplo. Então, acho o tradutor uma figura essencial. Acho que sou um ponto meio fora da curva nesse aspecto, porque, enquanto alguns amigos meus procuram sair dos bastidores, quero permanecer ali. Hoje em dia, com as novas mídias, a saída do tradutor dos bastidores está acontecendo cada vez mais. Algumas livrarias, não todas, colocam o nome do tradutor na ficha catalográfica. A Amazon e a Travessa fazem isso.

Lana: Como você vê o papel das resenhas na recepção e avaliação, pelo público, de um livro traduzido? O que você acha do tratamento que as resenhas de livros dão de modo geral ao tradutor da obra?

R.Z.: A gente sempre diz que, se o tradutor não é citado nas resenhas, é porque a tradução está boa. Na verdade, só citam o tradutor para criticar o seu trabalho. Dificilmente, você vai encontrar numa resenha um elogio ao trabalho do tradutor, que a tradução corresponde ao original. Já vi resenhas criticando muito a tradução e, nesse caso, o resenhista cita o nome do tradutor. Estando boa a tradução, o máximo que você encontra é apenas uma referência ao nome dele: livro tal e, entre parênteses, tradução de fulano.

Lana: Qual o grau de autonomia tradutória que você (e outros tradutores da Record) possuem? (Em termos de escolha de estratégias tradutórias etc.)

R.Z.: Total autonomia. Há casos em que você precisa justificar, porque o copy, que é o revisor que pega a tradução, pode ter uma outra opinião. Por exemplo, um termo que atravessa a história, que aparece em vários pontos da narrativa, um neologismo, como eu já mencionei. Aí procuro justificar por que fiz daquela 
forma. A editora, é claro, tem o poder de rejeitar a minha sugestão, de discordar do que eu propus e, nesse caso, quando há uma relação estreita entre tradutor e editor, este avisa que aquele termo que o tradutor criou ou sugeriu não ficou bom e que, por isso, será mudado. Já aconteceu comigo e eu já traduzo desde... mas nunca aconteceu comigo de mudarem radicalmente à minha revelia algo que eu tivesse criado ou sugerido.

Lana: Você tem acesso ao autor dos títulos que você está traduzindo, ou lida com intermediários?

R.Z.: Ah, sim. Hoje em dia, com as redes sociais, isso é muito fácil. Eu sigo a página de todos os autores que estou traduzindo, mas, por respeito ao editor, só entro em contato com o autor, se o editor me autorizar, porque há editores que não gostam. E isso eu entendo perfeitamente. Digamos que você seja a agente, eu, a editora e o fulano traduziu um livro do seu autor, seu cliente. Aí, o tradutor entrou em contato direto com ele e eu comento isso com você, que não está sabendo de nada. Algo do tipo “Ah, aquele problema que o seu tradutor apresentou...”. E você, editora, está completamente alheia ao que aconteceu. Pega muito mal para o editor, que tem que acompanhar todos os processos. Aconteceu comigo uma vez. Era um livro de ficção científica. Havia alguma coisa na história que não batia. Não me lembro exatamente o que era. Não sei se era um erro de continuidade. Era um erro do próprio original. Expliquei à editora o que estava acontecendo e ela me pediu para entrar em contato direto com o autor. E foi o que eu fiz, mas só fiz depois de comunicar a ela e depois de ela me autorizar a fazê-lo. E todas as mensagens que recebi do autor em resposta às minhas dúvidas copiei para a editora, para que ela estivesse ciente de tudo o que falei com o autor. 


\section{ANEXO J \\ Entrevista com a designer de capa Renata Vidal (22 de novembro de 2018)}

Lana: Fale um pouco da sua formação acadêmica e da sua trajetória profissional e também como você chegou até a Record.

R.V.: Eu me formei em jornalismo primeiro. Só que, durante a faculdade, eu já estava meio inclinada a seguir outro caminho. Eu queria trabalhar com design editorial. Por "n" questões, na época, eu não tive como mudar de curso, mas o destino foi me direcionando [para a área editorial]. O meu primeiro estágio foi na reitoria, no setor de relações internacionais, e eu tinha que escrever materiazinhas sobre bolsas e convênios da UFRJ e, aí, eu quis reformular o projeto gráfico do jornal. Mudou o reitor e o estágio acabou. Foi então que a minha chefe me chamou para estagiar na Ana Néri, a escola de enfermagem da UFRJ, no setor de publicação, onde eu fiquei por um ano. Eu fazia a diagramação da revista de enfermagem. Ali eu tive a certeza de que eu queria mesma era trabalhar com isso. Na Ana Néri, eu fiz amizade com um rapaz, que é meu amigo até hoje. Aí ele me disse que estava saindo de lá, mas que ia me chamar para trabalhar com ele. Ele saiu da Ana Néri e foi trabalhar no Festival do Rio. Foi quando ele me chamou para fazer o catálogo de filmes. Isso foi em 2000. Terminado o festival, ele me indicou para ser assistente da antiga designer do Estação, que também trabalhava como freelancer para editoras, a Tita Nigri. Ela saiu do Estação e ficou só como freela trabalhando para editoras. Ela é designer mesmo, é capista. Eu trabalhei com ela durante quatro anos. Aprendi muita coisa com ela. Foi através da Tita que eu tive o primeiro contato com a Record, pois ela própria fazia capa pra lá. A minha chegada à editora foi um processo longo. Ela fazia as criações de capa e eu fazia só correção. Ela costumava passar para mim o serviço de diagramação. Esse trabalho de diagramação que eu fazia para a Record era indireto, pois era encomendado a ela, que repassava pra mim. A Record encomendava um projeto de miolo, que era ela que fazia, e eu fazia a diagramação. Eu trabalhe com ela de 2000 a 2004, quando ela fechou o escritório. No ano seguinte, fui trabalhar na Fundação CECIERJ para trabalhar com livro didático. Fiquei lá por 8 anos. Foi durante esse período que fiz faculdade de design.

Lana: Como designer de capa, você trabalha com imagens prontas ou você mesma desenha à mão?

R.V.: Não. Muito raramente. Boa parte dos designers não ilustra, ou então, faz coisas mais simples. Há uns que fazem as duas coisas, mas a maioria, não. O design de capa é o seguinte: o editor me passa um briefing, uma sinopse do romance. Em alguns casos, pode pedir para ler o livro todo, mas normalmente fornece o briefing. Às vezes, já passa uma ideia pronta; às vezes, dá liberdade para criar. É um trabalho de pesquisa. Com base no tema, no assunto, no gênero, no público daquele livro, o designer vai pesquisar o que se costuma fazer em termos de capa para aquele gênero de literatura, o que o mercado tem. Eu vou seguir a mesma linha que o mercado segue ou vou fazer alguma diferenciada? Só que esse 
"novo” precisa ser uma coisa que o público aceite. Esse “diferenciado”, às vezes, é difícil de ser aprovado justamente por causa desse temor. Aí, eu começo a selecionar tipografia adequada, a trabalhar o título, tem que ter um certo conhecimento de tipografia. Às vezes, o lettering (tipografia, o tipo de letra) é feito à mão, mas nem todo designer faz assim. Eu também vou acessar zilhões de bancos de imagens, para fazer uma pesquisa temática pra achar uma imagem. Às vezes, vai ser uma composição com várias imagens que eu vou compor pra criar uma outra coisa e ressignificar. Às vezes, pode ser uma ilustração, às vezes é uma coisa até que eu ilustre, mas é difícil. Tem designer que ilustra, mas não é sempre. Eu, por exemplo, não ilustro. A não ser que seja uma coisa muito simplificada, mas, se for algo do tipo "um guerreiro na montanha”, não faço, não. Tem que contratar alguém pra isso. Agora, o designer pode ter uma ideia de ilustração e passar para o ilustrador. É possível essa encomenda de ilustração partir do editor. O editor já contrata o ilustrador com uma ideia. Isso também pode ser papel do designer de chegar e sugerir essa encomenda de ilustração. Isso é direção de arte. Vai definir até a cor que tem mais a ver com aquele assunto, com aquele público (3). A elaboração de capa envolve um monte de gente. Por isso, eu acho que não é uma coisa só minha. É todo um trabalho de equipe. Vai desde o autor, que escreveu o livro, que dá o embrião de todo o processo, é o editor, que dá um direcionamento, o comercial, que vai dizer o que vai funcionar melhor, o marketing, a equipe interna de design da Record também. Eles fazem reuniões pra decidir o que aprovar. Eu não participo dessas reuniões, porque é a equipe interna da editora. Como freela, eu envio o meu trabalho (proposta de capa), que é avaliado durante essas reuniões. Às vezes, a capa é aprovada de cara. Às vezes, pedem que mude um aspecto. Às vezes, pedem que mude tudo, que comece do zero.

Lana: Por exemplo, chega um briefing pra você. Aí, você tem mais de uma ideia para aquele livro. O que você faz? Você faz mais de uma e manda para que eles escolham uma?

R.V.: Isso vai variar conforme o design. Há uma corrente no design que defende que se envie ao cliente apenas um layout, porque mandar mais de uma opção demonstra que você não está 100\% certo daquele trabalho. Eu até entendo essa linha de raciocínio, tem um fundamento, mas eu acho que não funciona na prática. É até um pouco de arrogância eu ter a certeza de que aquela minha única sugestão é 'a' sugestão. Eu acho que é importante o editor, o comercial avaliarem. Mandar um só, se esse layout não agrada de cara, o editor vai devolver com sugestões, recomendações e, aí, você acaba fazendo mais de um. Eu, particularmente, prefiro mandar mais de um. Quando eu vou rascunhar, fazer os esboços, os estudos para aquela capa, eu vou fazer várias coisas. Aí, quando eu acho que está satisfatório, eu mando alguns caminhos. Aí, tem a questão da foto, em que se precisa fazer uma mudança sutil em relação à cor, por exemplo. Aí, a equipe da editora vai analisar as sugestões que eu envio e depois eles me dão o feedback. Eles é que conhecem mais o livro, conhecem mais o mercado. É um trabalho em equipe. A editora tem essa estrutura. É diferente de quando eu faço o projeto da capa segundo o briefing do autor. Às vezes, eu até brinco com a Renata, porque mando, por exemplo, três sugestões de capa e, das três, a minha preferida é, digamos, a 1. 
Aí, a equipe escolhe a 3. Nunca coincide de eu gostar da mesma capa que a equipe da Record. Só que eu acabo dando razão a eles. A palavra do comercial tem um peso grande. Eles é que sabem o que vai funcionar melhor em termos de venda.

Lana: Em que linhas editoriais do grupo você atua como designer de capa?

R.V.: Eu comecei com o selo Galera, fazendo trabalhos indiretos, como eu havia falado. Eu fazia só o miolo dos livros. A Galera estava iniciando. Foi quando a Ana Lima e a Giuliana Alonso me pediram para, além do miolo, editar umas imagens. Aí elas gostaram do meu trabalho e começaram a passar trabalho direto pra mim. Isso foi por volta de 2007, 2008. Foram os primórdios da Galera. Eu acho também que eu tive sorte, porque, como era uma editoria nova, ainda não haviam fechado a equipe de colaboradores. Eu fiz muito trabalho pra Galera.

Lana: É uma exigência da Record que o nome do tradutor figure na capa, independentemente de quem seja esse tradutor?

R.V.: Não. Muito raramente. Só quando o livro é inscrito num programa governamental é que há essa exigência. Se eu não me engano, tem uma coleção que usa o nome do tradutor na capa. É uma coleção da Galera. Aí eu me lembro que uma das editoras me falou que era para pôr o nome do tradutor na capa. Eu ainda disse "Poxa, mais uma informação para eu pôr na capa". E foi aí que ela me disse que era uma exigência do governo. Se for aprovado no programa - acho que é o PNBE (Programa Nacional Biblioteca da Escola) - tem que estar com o nome do tradutor na capa. Há uma série de exigências, como todas as páginas numeradas, o nome do tradutor.

Lana: Entre fazer a capa de um livro nacional e a de um traduzido, qual é a que dá mais trabalho? Pergunto porque, no caso do livro traduzido, você tem a capa do original.

R.V.: Como eu falei antes, eu comecei na Record pela Galera. Depois fui fazer ficção estrangeira para a Record e nacional pra Best Seller e pra Nacional, mas a Nacional só me passou miolos. Eu nunca fiz capa pra Nacional. Capa pra livro brasileiro fiz no selo Galera.

Lana: Considerando a sua experiência na Record, a capa da versão traduzida é normalmente muito diferente da original ou são modificações discretas, procurando preservar o máximo da capa original?

R.V.: Depende do projeto. Quando não se compra o layout da capa estrangeira, é porque a editora não quis ou porque tem alguma restrição de contrato ou porque os direitos sobre a capa original estão caros. Aí se faz uma coisa completamente diferente, mas já aconteceu de eu fazer layout parecido. Nesse caso que eu estou citando, a imagem usada na capa original era cara. Era um valor absurdo. Aí eles queriam que usasse uma imagem parecida pra dar o mesmo efeito da capa original. Teve o caso de um outro livro que a Record já tinha publicado o volume 1 e aí lançaram uma série de TV. E aí, no exterior, começaram a reeditar o livro com a capa contendo a imagem da série, mas a Record não quis mudar. Preferiu 
seguir a linha da capa que já vinha sido feita. Eu me lembro que o volume 2 tinha um layout estrangeiro, que não tinha sido usado. Eles mandaram o JPEG e eu tive que me virar para conseguir descobrir onde estavam aquelas imagens. E, num outro (volume), que só seguiu a linha da série (de livros), começamos do zero, mas seguindo o padrão adotado nos volumes anteriores. Pode haver ainda adaptações de capa, quando a editora adquire os direitos da capa estrangeira, compra o layout deles. Aí recebemos os arquivos estrangeiros. Nesse caso, a capa lançada aqui é "igual” à capa gringa, exceto por formato, textos etc. que são adaptados para nosso país. Fiz muitas adaptações de capa para a Galera, por exemplo. E há adaptações mais rigorosas em que precisam passar por aprovações externas ou mesmo rodam fora, em parceria ou não, como é o caso de livros de projetos de grandes estúdios, como os dos filmes do Harry Potter, ou de Star Wars, ou Assassin's Creed.

Lana: Há instruções da editora no sentido de se elaborar uma capa que construa ou reforce a imagem de um autor ou de uma obra?

R.V.: Eles podem dar instruções, que vão nortear a criação do designer. A não ser que já haja alguma coisa pronta antes, uma tipografia, uma cor, mas o direcionamento dado pelo editor é uma coisa mais vaga. Em alguns casos, sim, o editor pode dizer pra seguir o que vem sendo feito com determinado autor ou, então, alguma capa que tenha sido apreciada e que o editor pede pra seguir aquela linha. Nesses casos, o editor pode dar uma referência visual mais específica para que eu possa trabalhar. Por exemplo, na minha opinião, acho que essa capa aqui, do menino segurando a arma, dificilmente vai ser feita aqui.

Lana: Nessa mesma linha de pergunta, você poderia citar exemplos em que a editora tenha decidido elaborar uma capa para a versão traduzida com elementos culturais locais para tornar o produto "livro" mais palatável ao público brasileiro?

R.V.: Isso vai depender muito do livro. Cada livro, cada autor, cada gênero tem uma linguagem diferente. Também depende muito do público. Para cada público, é um tipo de capa que vai funcionar. Dificilmente, a editora vai me dizer que cor eu vou ter que usar. Pode até acontecer, mas é muito raro. Por exemplo, recentemente eu recebi um email de uma outra editora. Eu tinha enviado umas propostas de layout e eles me responderam pedindo para eu fazer outros com cores mais vivas, mas é muito difícil fazer esse tipo de recomendação. Pode até acontecer, mas como feedback. Digamos, eu achei que uma capa com tons pastel ia funcionar para um determinado livro direcionado para um público específico. Aí a editora responde dizendo que acha que a história ali é meio sombria e que cores mais fechadas funcionam melhor. Isso já aconteceu, mas como feedback. Não foi uma exigência inicial. Houve um caso em que eu fiz uma capa para um romance "hot" de época. Normalmente, para esse tipo de romance, que mais se vê é capa do tipo Sabrina e Bianca, que mostra um casal apaixonado. Quando eu penso numa capa, eu me coloco da posição de leitora, de consumidora. Eu vou tentar pensar numa capa que me faria comprar aquele livro. Todo mundo que, de alguma forma, participa da confecção de um livro tem que gostar de ler, tem que gostar de livro. Eu sou do tipo de leitora que compra o livro pela capa. Se eu achar que o livro tem uma capa linda, eu sou capaz de comprar o livro só por causa da capa. No caso desse romance aqui, desse hot de época, a Record topou seguir a 
linha que eu propus. A ideia era simular visualmente um livro antigo, de época realmente. Para isso, seria usado o recurso de hot stamping, que é uma impressão de lâmina metalizada. Nesse livro, haveria ornamentação dourada e uma inspiração retrô. É um elemento visual que encarece, mas, como a autora é importante e venda certa, eles toparam. E foi ótimo, porque o público adorou. Essa capa ficou completamente diferente dos outros romances do gênero lançados pelas editoras, de um modo geral. Até essa capa aqui, o que havia no mercado era aquilo batido, de um casal. Quando, no briefing, pedem criação de capa, é porque a editora brasileira vai seguir uma outra linha. É difícil ter um caso de criação de capa que seja parecida com a original. Quando a editora quer uma capa nova para a versão traduzida é para se fazer algo completamente diferente, que vá funcionar melhor aqui. Os livros da Elizabeth Hoyt são um exemplo. As capas das versões originais são do tipo Sabrina e Bianca. Um caso oposto são os livros da Cassandra Clare que formam a série Instrumentos mortais. É do selo Galera, da Record. Eu só faço algumas poucas adaptações em relação à capa original. No geral, tem que seguir à risca o layout original. O problema nesse caso é o título, porque, à medida que vão sendo traduzidos os livros da série, eu vou fazendo a capa. Só que o ideal era manter o padrão de tamanho de letra a partir do maior título, e então todos os volumes da série terem o mesmo corpo. As lombadas serem padronizadas na posição de entrada de título e aí depende do tamanho do título e da lombada. Quando já temos todos os volumes, é possível fazer essa previsão antes e criar um padrão que fiquei igual para todos. O leitor brasileiro é exigente nesse tipo de questão. Ele quer os livros na estante combinando. 


\section{ANEXO K}

\section{Entrevista com Anastácia Cabo (blog Notas Literárias - 06 de novembro de 2018)}

Lana: Como surgiu o Notas Literárias?

A.C.: O Notas Literárias surgiu assim: eu já era colaboradora num outro blog, um blog maior, de maior alcance. Só que eu queria exatamente eu mesma decidir o conteúdo a ser trabalhado: o que eu ia ler, o que eu ia resenhar, os livros sobre os quais eu gostaria de falar e não necessariamente sobre aquilo que o blog queria. Então, decidi que eu precisava pensar em um espaço pra mim, algo que tivesse $100 \%$ da minha cara e foi assim que decidi que precisava criar esse espaço. Foi aí que o Notas Literárias nasceu.

Lana: Explorando o blog, observei que há parcerias firmadas com autores e editoras, dentre estas, o Grupo Editorial Record, meu estudo de caso. Como se dão essas parcerias?

A.C.: As parcerias com as editoras acontecem assim: eles abrem inscrição, divulgam nas redes sociais e os blogs se inscrevem. Aí eles vão lá avaliar o conteúdo, se você (o responsável) se identifica com a linha de publicação deles e aí eles fazem a escolha. Em relação aos autores, a maioria eu já conhecia antes, em âmbito pessoal, e acabamos firmando a parceria justamente pela minha identificação com aquilo que eles publicam. Então, lá no blog, especificamente no meu, no Notas Literárias, eu só resenho livro com cujo autor eu me identifique $100 \%$. Tanto é que você deve ter observado que não há um monte de gênero, porque não é tudo que me agrada. Eu prefiro não investir meu tempo naquilo que não vai ser $100 \%$ de agrado meu e também não deixar que a avaliação do romance e do autor seja negativa. Porque, às vezes, a obra não agrada a mim, mas agrada a outras pessoas.

Lana: A tradução dos romances resenhados no blog é um aspecto que chama a atenção das resenhistas? Em caso afirmativo, que método é utilizado para se avaliar o trabalho do tradutor? Você se lembra de alguns casos?

A.C.: Sim, eu me lembro de muitos casos, sim. Dependendo do autor, eu já li a obra original antes de chegar ao Brasil. O primeiro ponto está aí. Então, quando eu leio o traduzido, eu sei exatamente o que eu espero encontrar ali. Muitas vezes, não é uma questão de avaliar (intencionalmente) o trabalho do tradutor. Não é isso. É que eu li a palavra, eu li a frase, eu li o contexto e entendi de uma forma. Aí, eu pego a tradução é outra totalmente diferente. Isso me causa espanto. Isso às vezes me leva a questionar o trabalho que foi feito. E, às vezes, não é erro do tradutor. Pra mim, às vezes, o que falta é uma preparação de texto pra transformar aquilo ali numa coisa aceitável pra nossa realidade. Porque há coisas que existem em outros países e que não existem aqui. Se não se fizer uma boa preparação de texto ali, você não vai ter a realidade que se adeque ao que você precisa. Eu lembro, inclusive, do caso específico do título de um romance lançado 
pela Record. Houve um evento em dezembro, aqui no Brasil, de que a autora Brittany C. Cherry participou. Na ocasião, anunciaram o lançamento do livro dela cujo título em inglês era Behind the Bars. Esse "bars" do título se refere a barras musicais (pauta musical) e conta a história de uma cantora e de um saxofonista. O título em inglês tem duplo sentido. E qual foi o título sugerido em português? Pelos bares da vida. E por que esse título? A história se passa em Nova Orleans e, como no início do romance, o protagonista era menor de idade e não podia frequentar os bares à noite, ele ficava na parte de trás, ouvindo as músicas. Só que a história era muito mais do que isso. Então, o título em português foi bem questionado. Aí, a editora resolveu troca por No ritmo do amor. Ficou mais adequado, porque é uma história de amor, de fato, e tinha a questão da música porque o protagonista era um saxofonista muito bom, apesar de não ter formação acadêmica. Ele aprendeu informalmente com o tio e era um virtuose. Então, Pelos bares da vida não tinha nada a ver.

Lana: Depois de traduzido, o texto passa por, pelo menos, uma revisão, o copy, que, segundo informações que obtive, tem dentre seus objetivos retificar eventuais equívocos de tradução. As resenhistas do blog estão cientes de que o que está sendo avaliado pode ter sido uma alteração feita pelo profissional de copy à versão do tradutor?

A.C.: Isso aí é uma coisa muito importante. A função do tradutor é traduzir o texto e traduzir o texto dentro da realidade daquele país, daquela língua para a qual o texto está sendo traduzido. E muita gente não tem essa consciência. Muita gente que hoje tem blog não tem a menor consciência do que venha a ser uma preparação de livro. É o que se chama de “preparação de originais”. Não fazem a menor ideia de como a coisa funciona. Então, sabem que o livro foi traduzido da língua “x” para a língua “y” e que ficou uma porcaria. E aí, a “porcaria” é o tradutor, porque é o nome que sai na ficha catalográfica. Não se conhece a escala de produção (editorial) e nem como essa escala funciona. As pessoas (que possuem blogs literários) precisam entender $100 \%$ como funciona a preparação de originais e, aí, sim, elas iam entender. Numa preparação de originais bem-feita, expressões ou termos esdrúxulos não passam, pois causam estranheza no profissional.

Lana: O blog também divulga obras brasileiras, correto? Há algum levantamento do quantitativo de obras nacionais e o de obras traduzidas?

A.C.: Muitas! Eu não tenho essa divisão no blog. É até uma ideia que eu posso montar a partir de agora mas, no momento. Não tenho esse dado para fornecer. O que eu posso lhe dizer é qual é a resenha mais visualizada lá. Isso eu lhe digo agora (acessando o blog) e eu acho que é uma obra brasileira. Não. Hoje, no blog, a postagem mais visitada é a de um livro da Lucinda Reily, que é uma autora traduzida e publicada pela Editora Arqueiro, e a segunda mais visitada é Soul rebel uma obra brasileira, de uma autora muito jovem, a Kimberly Mascarenhas Essa obra ficou muito tempo como sendo a mais visitada do blog. É um livro que não tem meio termo: ou você gosta muito ou você detesta. Se a gente for fazer uma média de visitas, ele continua sendo o líder. É um livro voltado para o público juvenil. 
Lana: Pelo que pude observar, a maioria dos romances resenhados é traduzida do inglês. Essa informação procede?

A.C.: Procede, sim. Na verdade, não é que eu seja fluente em inglês, mas leio bem. Como tenho um bom domínio do inglês, eu dou preferência aos livros em inglês. Sobre outros idiomas, eu não tenho domínio. Espanhol eu "arranho", mas eu nunca me aventurei. Mesmo que o autor seja espanhol, se existe a edição em inglês, eu vou dar preferência. Por isso, eu não posso dizer que eu tenha um ranking de línguas. Dentre as colaboradoras do blog, a única que lê em outro idioma sou eu mesma.

Lana: Há na equipe do blog algum membro responsável por rastrear e avaliar o potencial literário e comercial de obras estrangeiras? Nesse caso, o blog sugere obras para as editoras parceiras?

A.C.: A essa editora, onde estou trabalhando hoje, eu já tinha tido acesso e indicado alguns livros. Em conversas informais, eu mostrava um romance e dizia "Se vocês conhecessem isso aqui, seria uma boa ideia para publicar". Quando eu leio um bom livro e não tem ninguém aqui publicando, eu sempre recomendo, eu sempre falo nas minhas redes sociais ou na minha resenha. Se é um autor que já tenha sido publicado por alguma editora brasileira, eu marco a editora e falo “Olha, tem esse livro aqui. Não quer, não? Fique atenta”. Eu costumo fazer essas indicações indiretas, porque eu não tenho acesso pra isso. Exceto a Renata. "Está vendo este livro aqui? Acho que você deveria publicar, por causa disso, disso e disso”. Esses casos que estou citando são de autores já publicados no Brasil, mas há também os casos de autores desconhecidos, mas talentosos, que eu indico também. Existem muitos livros bons que ainda não chegaram ao Brasil. Aí entra a questão do que é comercial. Às vezes, as editoras não querem livros com títulos que contenham duplo sentido, que possam ter conotação sexual ou um xingamento, por exemplo. E hoje, com a crise, as editoras não estão investindo em nada novo, diferente. Só publicam aquilo que sabem que vende. Por exemplo, a autora " $x$ ", que sabem que vende, então, publicam. Com a crise, é muito difícil as editoras investirem em autores que sejam totalmente desconhecidos do público brasileiro. Não arriscam nem um subgênero de um gênero conhecido e rentável e nem vai conhecer o que nunca viu. Se você vai se aventurar a publicar algo completamente novo, seja pela obra em si u pelo autor, você tem que fazer um trabalho de divulgação muito bom, ou seja, a editora tem que investir em marketing, o que encarece o livro, que é um produto como qualquer outro. Por exemplo, lançamento simultâneo de original e tradução é muito difícil de acontecer em tempos de crise. O último que houve, e nem foi exatamente "simultâneo", mas foi muito próximo, foi o da Rosie Walsh, Tudo o que nos separa, lançado pela Record, e um do Nicholas Sparks, por outra editora. O Sparks é certeza de venda mesmo e a Walsh, que é uma autora nova, foi lançada naquele projeto deles (da Record), o VIB, que é uma caixinha que eles mandam para alguns influenciadores, quando é algum autor novo, que estão inserindo no mercado. Eles enviam 45, 60 dias antes do lançamento para esses influenciadores falarem sobre a obra para despertar o interesse. Esse projeto é muito legal. 
Lana: Você se lembra de algum romance de que você tenha gostado, mas que não tenha sugerido por achar que não teria vendagem no Brasil?

A. C.: Lá fora, existe um subgênero chamado "dark", que, no Brasil, ainda teria muita resistência no Brasil por tratar de temas tabu. É dirigido para o público adulto. Brasileiro, não parece, não, mas é muito retrógrado no que tange à literatura, no que tange a qualquer assunto que não o deixe confortável. Ele não vai lá encarar. Ele se retrai. O Brasil, na década de 80, era bem “prafrentex” e, da década 90 pra cá, só regrediu. O público leitor restringe muito. Por exemplo, se tiver romance entre uma mulher mais velha e um homem mais novo, não vende. Se a protagonista não for uma mulher jovenzinha, o livro não vende. Se for uma relação homoafetiva, não vende. 


\section{ANEXO L \\ Entrevista com o copidesque Rodrigo Austregésilo/Daniel Austie (15 de julho de 2019)}

Lana: Qual é sua formação acadêmica?

R.A: Sou formado em Publicidade pela UFRJ. Entrei em 2010 e concluí em 2016. Hoje a estrutura do curso de Comunicação Social mudou, mas, na minha época, era dividido em 4 habilitações: jornalismo, publicidade, produção editorial e rádio/tv. Eu sempre amei fazer as 4! Eu ficava transitando entre uma e outra. Eu sou apaixonado por livros! Sempre fui! E sempre gostei muito de escrever. Acho que é uma característica de quem opta pela produção editorial. São pessoas que, quando crianças ou adolescentes, tinham o sonho de escrever ou trabalhar com livro de alguma forma. Aí, quando eu estava no primeiro ou segundo período, surgiu a oportunidade de um estágio na Editora. Foi uma oportunidade que eu encarei com a melhor que eu tinha para me inserir no mercado. Eu ainda não sabia o que eu ia fazer, mas fui. Desde então, $90 \%$ da minha experiência profissional é no mercado editorial, tanto na área de marketing quanto na parte editorial. Hoje, eu trabalho no departamento de marketing de uma editora, mas ainda faço trabalho editorial como freelancer. Já trabalhei também como estagiário na parte editorial também na Record. No Galera eu fiquei dois anos e quase um ano no BestBolso, que é o selo de bolso da Record e no Best Seller também.

Lana: Na sua experiência de revisor, você já recebeu algum treinamento, ou mesmo workshops, que tenha sido oferecido pela editora para que o seu serviço de revisão se adeque aos padrões da editora?

R.A.: Não oficialmente. A adequação às normas da editora a gente aprende na prática. Eu tive incríveis tutores! Acho que isso foi um diferencial na minha carreira. Eu tive ótimos “professores” no próprio mercado editorial, gente em que eu me espelho. Como, ainda na universidade, eu escolhi publicidade, no mercado editorial, foi o pessoal que já trabalhava na área que me acolheu, que me pegou pela mão, eu ainda novinho. A minha experiência com texto, com a parte editorial veio do mercado mesmo. A minha referência maior no campo editorial são essas pessoas. Há coisas que a gente vai construindo. Por exemplo, a norma culta ninguém domina inteiramente, então, a gente vai aprendendo aos poucos. Cada editora tem uma padronização. Os processos são muito singulares também. Normalmente, existe o padrão, o caminho que o livro toma desde que ele chega no original, é traduzido até virar o produto final, mas, dependendo do livro, esse padrão pode mudar, de acordo com a necessidade do livro. Isso em relação a prazo, a ser um projeto especial. Por exemplo, se o livro for uma coedição, quer dizer, a editora estrangeira cuida de todo o processo junto com as outras editoras mundo afora. Por exemplo, foi o caso do livro da série Harry Potter que eu traduzi. Nesse volume havia muitas imagens oficiais, que envolviam direitos 
autorais, e que, por isso, não podiam vazar. E como a coisa acontecia: eu mandava o meu texto para o editor que me contratou, que, por sua vez, enviava o texto para o exterior, depois de revisado, claro. Aí, a editora estrangeira inseria as imagens e rodava o livro lá fora. Depois de tudo pronto, os exemplares são distribuídos para os seus respectivos países

Lana: Na condição de copidesque, qual o tipo(s) de intervenção que você mais faz nas traduções que você revisa ou seja, quais são as inadequações que mais comumente você flagra em traduções?

R.A.: Muitas vezes, o texto vem para o copidesque muito “duro”, quer dizer, vem com soluções um pouco automáticas, algumas frases não muito fluidas. É claro que isso depende muito da pessoa. É uma outra pessoa fazendo, e cada um tem seu estilo. São pessoas diferentes em cada uma das fases da cadeia e às vezes você está num momento que não é tão bom e deixa passar alguma coisa. Isso é normal. Por exemplo, quando eu vou orientar alguém que vai fazer o copidesque de algum livro, eu falava para o copy ficar atento, porque o texto, muitas vezes, vem do tradutor duro, porque o tradutor pode estar fazendo mais de uma tradução ao mesmo tempo. Aí, a tradução vem um pouco mais automática, um pouco mais dura, um pouco mais truncada e o papel do copidesque é transformar aquele texto duro num livro. Não que ele já não venha um livro, mas é transformar num texto mais fluido, mais corrente, mais fácil. A maior ocorrência é essa. Não são propriamente erros. Às vezes, o tradutor usa ferramentas de tradução como auxílio, não para fazer a tradução toda. Eu mesmo, quando traduzia, usava para ver a tradução de uma palavra, de uma frase, que não é usada aqui. Eu costumo dizer que os meus melhores “amigos” são o dicionário de sinônimos e os dicionários informais gringos. Às vezes eu jogo lá uma palavra que eu não faço ideia do que signifique. É comum o tradutor estar num ritmo de trabalho muito apressado e deixa passar ou traduz literalmente. É aí que entra o copy, que vai fazer essas adequações.

Lana: Nesses dois anos de pesquisa em que entrevistei alguns profissionais do mercado editorial, uma palavra que ouvi muito, incluindo de você, que é o primeiro copy que entrevisto, é “fluidez" ou "fluência”. E se o texto original não for fluido, qual é a orientação da editora? Imprime-se uma fluência, uma fluidez para facilitar essa leitura?

R.A.: Não. Normalmente, isso é uma escolha editorial, mas, no caso, vem uma orientação editorial alertando que aquele autor tem um estilo diferente. $\mathrm{O}$ que acontece é que o copy tem duas tarefas: a primeira é a de tornar o texto mais fluido e a segunda é a de fazer o cotejo, ou seja, ele lê linha a linha, tradução e original. É nessa hora, na hora do cotejo, que você pega termos que o tradutor traduziu automaticamente, saltos que o tradutor faz sem querer. Neste caso, a gente tem que sinalizar que estavam faltando, por exemplo, dois parágrafos. Aí, 
não sendo uma coisa muito extensa, a gente traduz. Se for, o editor pede para o tradutor fazer. Se, no meu cotejo, eu perceber que o estilo do autor não é fluido, vou tentar adequar a tradução o mais próximo do original possível. Acho que, em relação ao estilo do autor, há escolhas que vão muito do editorial mesmo, como o editorial quer conduzir aquele livro. Vou dar o exemplo do Harry Potter. Eu só fui ler o original dessa série quando eu fui traduzir. Antes disso, eu só havia lido as versões traduzidas. Foi aí que eu fui ver que havia marcas de oralidade no original que não havia na tradução. Havia personagem que falava tudo errado, mas a opção foi a de que prevalecesse a norma culta. O máximo de marca de oralidade que eu vi nas versões traduzidas era o " $\mathrm{r}$ " de um personagem que tinha sotaque francês, mas é uma coisa a que o leitor brasileiro já está mais habituado. Havia outros que tinham outros sotaques como o escocês e o dinamarquês, mas esses não foram marcados, pois o leitor infantil poderia se confundir. Eu deduzo que tenha sido uma decisão do editorial, com a qual eu concordo. Muitas vezes, é preferível que se neutralizem algumas coisas. Infelizmente, a tradução não passa cem por cento do autor e da história. No caso do Harry Potter, eu acho que a prioridade era a história. Quanto mais o leitor fosse envolvido pela narrativa, melhor.

Lana: No total dos copies que você faz, qual é, em média, o percentual de intervenção que você precisa fazer?

R.A.: É de caso a caso. Tudo depende da qualidade do texto mesmo. Houve casos em que eu praticamente tive que reescrever a tradução e houve casos em que eu precisei enviar um email para o editorial avisando que eu quase não tinha feito emenda. Isso para que o editorial não achasse que eu não havia feito o serviço. Era porque o texto estava muito bom. Com a experiência, você já conhece o trabalho do tradutor, você já sabe que vai trabalhar muito ou quase nada. Há tradutores com os quais eu gosto de trabalhar, em cujo texto eu gosto de mexer. E faço isso com certa tranquilidade porque sei que as emendas que eu faço são sugestões e que serão avaliadas. Se, lá na frente, o editor achar que as minhas sugestões não valem, ele vai tirar. Eu tenho uma tendência a ser mais mexedor. Há outros copies que dizem que preferem respeitar mais o trabalho do tradutor e pouco alteram o texto, independente da qualidade da tradução. Isso depende muito de como o copy foi treinado. A pessoa que me treinou como copy é mexedora também. Agora, se for uma mudança que mexa no sentido, na intenção do autor, aí eu sinalizo: "O autor quis dizer isso, mas isso não funciona no Brasil”. Se, por exemplo, o autor diz alguma coisa que possa causar melindres, eu sinalizo. Aí, a editora decide se vale a pena contatar o autor e perguntar se pode adaptar. Eu tive uma experiência que era um livro da década de 1970 e que foi relançado. Nesse livro, o autor sugeria terapia de choque elétrico para a “cura de homossexuais” e aí eu apontei. Disse que era problemático e que eu achava que a gente poderia achar uma forma de dizer que a editora não pensava dessa forma. A solução que a editora encontrou foi a de colocar um aviso, uma nota, de que não concordava cem por cento com as soluções do autor. Era um livro de não ficção. São livros que foram lançados 
numa época, mas a editora não pode garantir que todos os leitores hoje vão entender dessa forma e que não vão se ferir com aquilo.

Lana: Se você tivesse que conceituar um texto bem traduzido, como você o definiria. Quais as características que, na sua opinião, um texto bem traduzido deve ter?

R.A.: Com certeza, a fluidez do texto, se for o caso de o original ter essa fluidez, mas normalmente tem. A ficção popular, mais mercadológica, mais pop, tem uma narrativa fluida. Fluidez, com certeza é o ponto principal. Há que se atentar à "subjetividade do original”. E o que eu quero dizer com isso? Vou dar um exemplo dentro do gênero com o qual eu tenho mais experiência, que é a literatura infantojuvenil, porque eu trabalhei no selo Galera por muito tempo. Por exemplo, às vezes, o tradutor está com um texto que é fantasia, uma aventura de fantasia, e ele usa termos populares, muito contemporâneos, muito urbanos, e essa fantasia não pede isso. Isso seria inadequado. Ou, então, o contrário: um texto super contemporâneo e ele não faz uma escolha boa de vocabulário, os diálogos ficam truncados e, aí, a gente adequa. Isso muda toda a "subjetividade do texto", o estilo do autor. Eu nunca traduzi ficção, mas, se eu fosse traduzir alguma, eu ia estudar o autor, entender como é que ele trabalha, que tipo de texto ele produz. Como eu só traduzi não ficção, eu acho mais fácil. Mas, mesmo como copidesque, eu preciso saber quem é o autor, para que eu possa avaliar se as soluções do tradutor estão adequadas. As que não estiverem, eu vou adequando. Mas a questão é que é inevitável que o copy passe por uma subjetividade nossa. Eu posso escolher uma palavra que você jamais escolheria e vice-versa. Todo mundo deixa a sua marca no seu trabalho. Já aconteceu de eu não reparar o nome do tradutor e começar o trabalho. Aí, eu começo a identificar quem é: “Nossa! Isso tem a cara do fulano”. E aí, eu vou ver e é exatamente a pessoa em quem eu pensei.

Lana: Como você avaliaria, de um modo geral, o tradutor brasileiro?

R.A.: É muito difícil fazer essa avaliação, porque o número de tradutores trabalhando para editoras é enorme. Pela minha experiência de copy, eu posso lhe dizer que é muito diferente o trabalho de cada pessoa. No geral, são bons trabalhos. Mesmo eu sendo mexelhão, eu posso dizer que, no geral, os trabalhos de tradução são bons. Eu faço mais trabalhos bons do que trabalhos difíceis.

Lana: Você faz mais traduções ou mais copy?

R.A.: Faço muito mais copy e faço também a liberação do copy. Às vezes, as editoras precisam mandar até isso pra fora. Normalmente, é um serviço interno, mas, às vezes, é necessário recorrer a alguém de fora da editora. Cada editora tem um processo e isso varia de caso a caso, mas, normalmente é o seguinte: chega o 
texto estrangeiro, que vai para a tradução, da tradução vai para o copy. Quando chega do copidesque, alguém de dentro da editora libera esse copidesque. Quando chega a liberação, vem o arquivo sem emenda, só com um comentário ou outro para eles avaliarem e, depois, liberarem. Depois, o livro vai para a diagramação. Aí, o livro vira um arquivo em PDF com páginas e, aí, o livro vai para a revisão. Quando chega da revisão, se eles não liberarem internamente o copidesque lá atrás, e eles tiverem mandado essa liberação pra fora da editora, vão obrigatoriamente liberar a primeira revisão. Aí, passa por uma segunda revisão e, se for muito problemático, o livro passa por uma terceira revisão, o que é raro hoje em dia. Aí, vêm as conferências, o checklist e tudo mais.

Lana: Você disse que faz menos traduções do que copidesque...

R.A.: É porque, hoje, eu trabalho no departamento de marketing de uma editora e tradução é um trabalho que consome bastante tempo. Às vezes, é um projeto que você para tudo pra fazer. Então, não estou fazendo muita tradução. Faço copy e liberação de copy também. Eu também não traduzi tantos livros. Traduzi quatro livros sobre o Harry Potter, dois para o selo Galera, da Record, e dois para a Harper Collins, e um livro de autoajuda que ainda não foi lançado.

Lana: Na condição de profissional do copidesque, você é um dos agentes da cadeia produtora de obras traduzidas. Ao longo da sua tarefa, você tem algum contato com o tradutor, há alguma interação entre você, copy, e o tradutor?

R.A.: Se necessário, dependendo do tradutor, sim. Aí, eu falo com alguém do editorial, pergunto se posso fazer contato. Nunca tive problema quanto a essa autorização. Mas é raro isso acontecer, porque o tradutor é um sujeito muito sensível da história, porque é quem mergulha inteiramente naquilo. É de praxe que o tradutor traduza tudo e revise a sua tradução em seguida. Então, normalmente, ele sinaliza alguma coisa que seja mais específica: "Olha, isso estava assim o original, eu pesquisei e a solução que eu encontrei foi esta”. Aí, você comenta ali: “Concordo", "Discordo. Eu diria assim”. É muito raro esse contato com o tradutor. Essa interação é via comentários no arquivo em Word. É muito raro eu ter que conversar com o tradutor diretamente. No máximo, quando o livro sai, eu vou lá e comento: “Ah, fui eu que fiz o copidesque desse livro! Eu amei!”. Mas é bem raro.

Lana: Enquanto fiz copy para uma editora grande aqui do Rio de Janeiro, eu sentia que havia uma hierarquia na cadeia editorial e que o tradutor estava acima do copy nessa estrutura hierarquizada. Procede essa minha impressão? Quando você disse que "o tradutor é um sujeito sensível” nessa cadeia, de certa forma, tem a ver com essa "hierarquia”? 
R.A.: Existe, sim, mas a posição hierárquica mais alta é a do editor. É por isso que eu não me importo muito de mexer no texto, pois sei que a última palavra é a do editor. Quando é o caso de um tradutor renomado, o editor avisa, que é para o copy segurar um pouco na mexida. Só que, em toda a minha carreira de copy, eu só recebi essa recomendação umas duas vezes. Acontece também de um tradutor muito conhecido ser quem vai liberar o copidesque, para avaliar as emendas. Aí ele vai dizer o que acha, mas isso é bem raro hoje em dia. Talvez até seja praxe em algumas editoras, mas, nas que eu trabalhei, esse retorno ao tradutor é muito raro.

Lana: Você já fez copy de alguma autotradução?

R.A.: Não. Nunca fiz. Seria um trabalho muito difícil mesmo. Como você iria fazer o copidesque de um livro cuja tradução foi feita pelo próprio autor?

Lana: Vou voltar à imagem do "tradutor como elemento sensível na cadeia editorial”. Você acredita que essa "sensibilidade” se deva ao fato de que o tradutor ser autor do texto traduzido, ou seja, o copy é mais uma leitura.

R.A.: Sem dúvida, o tradutor tem uma autoria. Tanto isso é verdade que é o tradutor que assina o termo de cessão de direitos autorais e não o copy. A tradução dele é uma autoria, mas não é só por isso, não. É porque é ele que mergulha naquele universo, especialmente na ficção. Ele precisa estar ali inserido para entender o tom daquele livro. É o tradutor que avisa sobre pontos do texto: "Olha, isso aqui significa isso. Eu pesquisei. Está aqui a referência”. É uma preocupação minha como copy também: se eu faço uma mudança muito grande na tradução, da mesma forma como o tradutor faz, eu aviso que estranhei isso, fui no original e pesquisei. Escolhi substituir por isso, porque é o que está escrito no original. Isso é mais frequente no vocabulário, mas acontece também em estrutura de frase. 


\section{ANEXO M \\ Entrevista com a editora Suelen Lopes (20 de novembro de 2019)}

Lana: O que faz um editor?

S. Lopes: Na verdade, o papel do editor varia de editora para editora. Na editora onde trabalho existem duas categorias de editores. O editor de aquisições, que é quem negocia os direitos autorais das obras vindas lá de fora. O editor de produções, que é o meu caso, começa o seu trabalho a partir do original estrangeiro. Eu coordeno todo o processo que começa na tradução até o livro impresso, a formatação final, miolo, capa. Eu não trabalho com a questão da aquisição do livro estrangeiro. Por isso, não tenho acesso aos scouts, aos contratos, aos royalties, a combinação de porcentagem de vendas, não trabalho com nada disso. Meu trabalho é com a produção mesmo.

\section{Lana: Existe alguma outra categoria de editor?}

S. Lopes: O que existia era um departamento de aquisições, que era separado do departamento de produção, o que não era bom para a execução do produto. Isso porque o editor de aquisições levava um tempo enorme para avaliar o livro e a editora só conseguia publicar dois anos depois, por exemplo. Hoje em dia, esses dois departamentos estão integrados, formando um grande editorial. O que existe hoje são três frentes: os livros "jovens", os livros mais comercias, que a gente chama de "trade" (ficção e não ficção) e os literários, que são livros mais complexos, que englobam ficção e não ficção. Na categoria “jovem” estão inclusos quadrinhos, muita ficção científica e picture books.

Lana: Sei que não é da sua competência a questão de aquisição de títulos, mas, no geral, quais os critérios que a editora onde você trabalha adota para escolher um livro para a tradução?

S. Lopes: No geral, os editores leem as histórias e, a partir dessa leitura, eles avaliam várias coisas. É claro que eles acabam sendo influenciados pelo seu próprio gosto pessoal, mas acho que o editor de aquisições, estando ali profissionalmente, acaba ultrapassando o seu gosto pessoal. Então, o editor de aquisições lê a história, entende aquela história dentro da sua cultura e analisa o potencial de vendas daquela história. Isso é debatido entre os editores de aquisição e o dono da empresa também, que é que normalmente tem a palavra final sobre os livros. Tem a questão dos leilões também que eles analisam muito antes de participar. Às vezes, é um leilão em que muita gente está fazendo oferta. Você vê que o livro é interessante, mas para ter um custo de publicação " $x$ ”, pois sabe que assim vai funcionar, mas, quando entra muita gente, até que ponto se sobe a oferta e aí o livro não responde o esperado nas vendas. O leilão é um funil, um gargalo, e é quando ficam no final as editoras com mais dinheiro. Uma editora menor, 
mesmo fazendo um trabalho bom, não consegue ficar. Por exemplo, nessas feiras internacionais, quando o livro já chega ali com muito burburinho é porque o valor dos direitos será muito alto.

Lana: No processo de publicação de livros traduzidos, a tradução é uma das etapas. Como o mercado editorial, de um modo geral, vê essa etapa, como central ou apenas como mais uma etapa?

S. Lopes: Se não vê como central, deveria. Eu não diria “central”, mas, como eu costumo dizer, quando um livro já nasce com uma tradução boa, as chances de ele ser incrível são muito maiores. Não sei se central, mas fundamental. Por isso a gente tenta priorizar o tradutor que apresenta um bom trabalho, um texto adequado, que a gente avalie como uma boa tradução. Em virtude da correria, a gente não pode privilegiar nenhuma etapa, pois, se não, acaba por negligenciar em outras, porque a questão mercadológica envolve outros fatores também. Mas reconheço que a etapa da tradução é fundamental para o livro ser bem-sucedido comercialmente.

Lana: Como você escolhe um tradutor para uma determinada obra? Quais os fatores que você leva em consideração?

S. Lopes: É aí onde começa o meu trabalho mesmo. Partindo do suporte do editor de aquisições (como o livro é, que história ele conta), eu avalio os possíveis problemas de tradução. As dificuldades da língua de partida podem ser recriadas na língua de chegada para não ter esse total afastamento da língua original. No geral, a gente trabalha com muitos tradutores de confiança. São pessoas cujo trabalho você conhece, que já traduziu muito para a editora, então, eu costumo priorizar essas pessoas. Nem sempre eu consigo avaliar um livro pra tradução, tendo lido, digamos, $90 \%$ do livro. O que eu consigo ler é 10\%, 15\% do livro. É o suficiente para eu identificar que tradutor dará conta daquele trabalho. No geral, são profissionais já consagrados no mercado. É muito difícil um tradutor novo conseguir uma porta. É complicado mesmo, porque é uma rede profissional em que as pessoas já se conhecem. Se o tradutor me apresenta trabalhos de qualidade, eu não tenho motivos para escolher outro. Até porque, no geral, a gente não tem muito tempo pra avaliar novas pessoas. O que às vezes eu faço é ver o site de outras editoras cujas publicações eu leio e considero boas traduções e vejo qual é o tradutor. Outra situação é quando nenhum dos tradutores da equipe está disponível e eu preciso buscar alguém de fora. Ou a gente pede recomendação ou, então, testa mesmo, porque é uma caixinha de surpresa. Às vezes, é uma pessoa recomendada e, quando você vai ver o texto, vê que vai dar muito trabalho para as etapas que vêm depois da tradução. Às vezes, é uma pessoa desconhecida que entrega um trabalho super bacana. Eu já tive as duas experiências. 
Lana: Pra você, Suelen, o que seria um tradutor ideal?

S. Lopes: Que pergunta difícil! Não sei se o termo aí é “ideal”, mas um bom tradutor é aquele que lê, que sabe avaliar os desafios daquele livro, o que aquele livro tem de importante, a voz. O bom tradutor também é um bom falante que domina bem a língua portuguesa. É claro que ele precisa dominar a língua de origem, seja ela qual for mas, se ele tem um bom português, já facilita $200 \%$ o trabalho. A tradução é um trabalho interpretativo e o tradutor vai colocar a sua subjetividade no trabalho de tradução. E também que seja uma pessoa que seja boa de lidar.

Lana: Bem, o tradutor é o agente da tradução. E como você definiria uma boa tradução?

S. Lopes: No geral, a boa tradução não difere do bom tradutor. O ideal é que o texto em língua portuguesa funcione, que seja fluida, que respeite o estilo do original, que tente reproduzir os desafios do original. Uma outra questão são as perdas. Quando no texto traduzido foram mantidos elementos não traduzíveis, a tradução fica capenga. Tem gente que preza pela tradução literal, achando que é a mais fiel possível ao original e, no geral, não, né? Quando você lê uma tradução literal, o estranhamento é muito grande, você tem dificuldade de ler. Então, será que é esse o caminho, o da tradução literal? É aí que entra o profissional da etapa que sucede a tradução, que vai ler lado a lado original e tradução, e tentam ajustar o texto. É claro que eles seguem diretrizes textuais para executar o seu trabalho, mas a ideia é que o texto final não seja igual ao de origem. Até porque é impossível ser igual. Seguir o original de perto não é fazer uma tradução literal.

Lana: Falando em cotejo, na sua editora há etapas de revisão?

S. Lopes: Em todas as editoras há etapas de revisão. A primeira, que faz o cotejo, pode se chamar "revisão de tradução”, "preparação" ou copidesque. Nessa etapa, o profissional trabalha com os dois textos, original e tradução. Nas outras etapas, chamadas mesmo de "revisão", o profissional nem tem acesso ao texto estrangeiro, pois o objetivo é ver como o texto vai ficar em língua portuguesa. Esses termos variam de editora pra editora.

Lana: O tradutor é freelancer. E os revisores, incluindo o copidesque, também são freelancers?

S. Lopes: Sim. Hoje em dia, poucas são as editoras que têm departamento interno de revisão. Desde o tradutor até o revisor, esses profissionais costumam ser terceirizados. 
Lana: Há uma delimitação de searas, por exemplo, o revisor não pode mexer em tais ou quais coisas, ou seja, há uma hierarquia em que o tradutor figure num patamar superior?

S. Lopes: De certa forma, existe, sim, porque o tradutor é o primeiro profissional que vai fazer as escolhas fundamentais para a obra ser o que é. Mas isso varia. Às vezes, o texto traduzido chega à primeira etapa de revisão pecando um pouco e, aí, o revisor se sente um pouco mais livre para fazer intervenções. Mas esse é um cenário que eu dificilmente vejo e que não é o recomendado. Então, existem essas delimitações, sim. O tradutor é o profissional que vai criar, ou melhor, recriar a obra em língua portuguesa que, embora seja uma nova obra, tem tudo a ver com a obra que lhe deu origem. O copidesque (ou revisor de tradução ou preparador) é que vai poder fazer grandes intervenções na tradução, mas isso se limita a inadequações, seja de construção de frase, um termo, uma voz irônica que se perdeu. É o copidesque que detecta essas inadequações e corrige.

Lana: E em relação aos paratextos (texto de orelha, prefácio) há situações em que o tradutor redija esses textos que tem por finalidade apresentar e, em alguns casos, guiar a leitura?

S. Lopes: Só quando solicitado. Dificilmente, o tradutor vai fazer uma apresentação. Na minha experiência, isso nunca aconteceu, mas, quando acontece, é uma decisão editorial. Talvez, isso seja mais frequente em livros acadêmicos, mais sofisticados, mas, em livros mais comerciais, eu nunca vi acontecer.

Lana: O título de uma obra é uma coisa capciosa. Como é que você chega ao título ideal para uma obra traduzida?

S. Lopes: A gente tenta fazer em português um título o mais próximo do título estrangeiro. Quando fica uma tradução muito literal e que acaba não soando bem, não tendo apelo comercial, a gente repensa. Cai no mesmo problema da tradução literal no próprio texto. A partir dos anos 90, a internet mudou muito isso, porque as pessoas têm mais acesso às produções, principalmente as de língua inglesa. Com isso, veio uma atenção maior com relação à escolha do título, do nome de personagem. Quando se traduz nome de personagem, por exemplo, tem leitor que fica indignado. Às vezes, é um apelido que, em razão do contexto, precisa ser traduzido para o português. Isso gera uma comoção enorme. Mandam mensagem direto para o contato da editora, elogiando, enviando errata e, principalmente, pelas redes sociais (Instagran, Facebook). 
Lana: A capa também uma identificação importante. Fale um pouco sobre isso.

S. Lopes: Normalmente, a gente reproduz a capa estrangeira. Só quando a gente acha que não vai funcionar aqui, se cria uma nova. Aí, eu faço uma pesquisa de palavras-chave, referências de outras capas, estéticas que eu considero que contam aquela história através de imagem, então, tem muita pesquisa para se chegar a uma capa ideal, quando não se reproduz a estrangeira. Essa questão da capa pode constar do contrato de direitos autorais. Às vezes, há uma cláusula que impõe que a capa da tradução seja submetida à avaliação de quem detém os direitos autorais lá fora. Também se pode comprar não a capa do original propriamente, mas a da tradução feita em outro país que foi considerada melhor do que a original.

Lana: Há algum contato entre o tradutor e o copidesque?

S. Lopes: Direto, não, O que o copy deixa no documento Word com a tradução são comentários que o editor vai ver. O texto, depois de traduzido, dificilmente volta para o tradutor. Já houve tradutores que pediram para ver o que foi modificado da sua tradução, mas foram muito poucos. A palavra final é sempre do editor. Fazer isso com todas as traduções seria inviável por causa do ritmo de trabalho. Por exemplo, uma tradução com muitas inadequações: eu não teria tempo de gerenciar esse contato. Por exemplo, já aconteceu de alguém me perguntar sobre o trabalho de um determinado tradutor e eu dizer que é ótimo, mas que ele pede pra ver como ficou o texto depois do copy. Aí o editor não quer aquele tradutor, porque diz que vai criar problema.

Lana: E a questão do lançamento simultâneo?

S. Lopes: Lançamento simultâneo acontece muito com livros jovens. O leitor, pelo meio digital, descobre que o lançamento lá fora vai ser na data "x" e, não conhecendo a cadeia produtiva enorme que está por trás de um livro, acredita que é fácil lançar aqui na mesma data. Quando é um livro que vale a pena, a gente opta for fazer o lançamento simultâneo para não descolar do lançamento lá de fora. É uma escolha da editora brasileira. Aí a gente faz de tudo para acelerar essa cadeia, mas sabendo que corre o risco de o livro sair com problemas. É muito desgastante, mas, em geral, a gente consegue fazer. Não é possível fazer lançamento simultâneo com todos os livros. Com a internet, é tudo muito instantâneo, e acaba gerando ansiedade no leitor. Esse processo é corrido, quando a editora lá de fora demora a liberar o manuscrito pra gente. Essa demora costuma acontecer no caso de uma obra muito aguardada, que, pra não vazar informações, eles seguram o manuscrito. Mas, quando eles liberam o manuscrito com antecedência, aí é mais tranquilo. Aí a gente assina os termos de confidencialidade se comprometendo a não vazar informação e o processo transcorre com tranquilidade. 
Lana: E no ranking de línguas estrangeiras, o inglês continua liderando?

S. Lopes: Sim! Com toda a certeza do mundo! A segunda língua é mais flutuante, porque tem fases. Houve uma época que a segunda língua mais traduzida era o francês. Hoje em dia, está dividido entre o italiano e o espanhol, talvez pendendo mais para o espanhol. Mas entre o inglês, primeira colocada, e o espanhol e o italiano, que se revezam na segunda posição desse ranking, a diferença é imensa! Assim, "chutando", porque eu não tenho um levantamento estatístico preciso, eu diria que o volume de obras traduzidas do inglês, no geral, é de $90 \%$ a 95\%.

Lana: Como é que se chega ao valor pago por lauda?

S. Lopes: Cada editora tem a sua tabela. Nas duas editoras onde trabalhei, incluindo a atual, quando eu entrei para as empresas, as tabelas já existiam. Para os tradutores com quem eu trabalho com mais frequência, eu costumo reajustar esses valores, mais ou menos, de dois em dois anos. Na editora onde estou hoje a formatação de lauda adotada é de 2100 caracteres com espaço no Word. O que acaba acontecendo é que, às vezes, esse valor varia de tradutor para tradutor. Por exemplo, um tradutor especializado que faz um trabalho mais que oferece mais dificuldade, recebe um valor mais alto por lauda. Outro caso é o tradutor que tem muito nome no mercado. Aí a editora oferece um valor de lauda que esse tradutor considera baixo e aí pode haver uma negociação. Aí o setor financeiro avalia se é viável ou não. Em editoras grandes, o que costuma acontecer também é uma tabela de valores com base no idioma: valor da lauda para tradução do inglês é tanto, do espanhol é tanto; línguas mais raras o valor é maior. O que acontece lá na editora é que eu tenho uma certa margem de mexer nesses valores quando se trata de um tradutor com quem eu trabalho há muito tempo, que eu sei que me entrega um trabalho super adequado, dentro do prazo, aí eu consigo negociar um valor de lauda um pouco maior. 


\section{ANEXO N \\ Entrevista com a tradutora e professora Teresa Dias Carneiro}

Lana: No campo editorial, pelas informações que obtive, você tem dois tipos de experiência, como tradutora e como editora (proprietária de casa editorial). Você poderia falar um pouco dessas suas experiências?

T.D.C: São duas experiências muito diferentes. Fui sócia de uma editora, a Contraponto, em 2014, que é uma editora que trabalha com uma linha de livros que se chama de "cauda longa”, quer dizer, "de venda demorada”. E, no que se refere à tradução, é uma editora que trabalha com tradutores especializados, pois publica obras na área de filosofia, de filosofia da ciência, um pouco de economia. São áreas técnicas bem delimitadas. Então, os tradutores da Contraponto não são tradutores de carreira, profissionais. Na verdade, são professores universitários que traduzem, que conhecem bem um determinado campo. Essas traduções passam por várias revisões de português (gramática), porque, às vezes, esse não é o forte desses tradutores. A revisão se faz mais por uma questão textual. Essa minha experiência como sócia de uma editora e mesmo como tradutora, pois eu traduzia também para a Contraponto, é um pouco diferente da experiência que tive como tradutora para outras editoras. Eu traduzi para a Intrínseca, para a Sextante... Nessas editoras, eu trabalhei mais com o tipo de tradução que não é o foco da Contraponto. São dois tipos de tradução bem diferentes. A Contraponto busca o tradutor especializado naquele campo e depois submete a tradução a várias revisões, enquanto que essas outras editoras buscam os tradutores ditos profissionais. As traduções passam por revisões, sim, às vezes por uma questão até técnica. Eu trabalhei mais na área de tradução de não ficção, a chamada tradução técnica.

Lana: De um modo geral, como as editoras selecionam seus tradutores e o que esperam desses profissionais? E no caso da sua editora, como os tradutores eram selecionados e qual a sua expectativa em relação ao trabalho desses profissionais?

T.D.C.: Pela minha experiência, eu diria que o acesso de tradutores a editoras é mais por indicação. Não estou dizendo que não se façam testes. Acredito que algumas editoras realizem, sim, mas o que vejo é que é mais por indicação mesmo. Às vezes, você tem um amigo que está trabalhando para aquela editora e, naquele momento, a editora está precisando de um tradutor, e esse amigo indica você. Sempre foi muito por indicação. O fato de eu ser professora tem uma importância nisso, porque, nas minhas turmas, tinha pessoal de editora e aí acabava me convidando para trabalhar. A Intrínseca foi uma delas. Eu tinha um aluno que era editor da Intrínseca, mas eu o conheci na condição de aluno. Na verdade, eu nunca fui para as editoras me apresentar. Normalmente, as editoras me procuravam, porque alguém havia indicado o meu nome. E o que se espera de um bom tradutor? Eu lhe diria que seriam habilidades autorais. Eu acho que as editoras procuram alguém que tenha um talento além da tradução. Até parece que traduzir é fácil, mas o que as editoras procuram é alguém que saiba o que funciona 
e o que não funciona num texto, ou seja, é um olhar autoral, que é mais do que traduzir. Às vezes você traduz corretamente, mas o revisor muda o que você escreveu. É por isso que os textos traduzidos passam por revisões. É na revisão que o revisor vai sentir se a solução do tradutor funciona em português: uma construção sintática, um termo. Muitas vezes, a revisão ocorre não apenas para checar se a tradução está correta, mas para tornar aquele texto mais condizente com a língua alvo. As editoras procuram no tradutor um profissional do texto, digamos assim. Ele está na função de tradutor, mas ele precisa traduzir pensando como revisor também. Posteriormente, o texto traduzido pode ser modificado para que o texto se adeque melhor ao estilo (perfil) da editora. As editoras gostam quando o tradutor, durante o processo da tradução, leve dúvidas para entregar o texto com o mínimo de pendências possível. Isso poupa tempo e trabalho. Isso, para as editoras, é muito interessante, pois agiliza o processo. Há prazo para tudo. Um tradutor que tenha essa visão mais ampla do trabalho editorial é o que as editoras buscam.

Lana: Como é o processo seletivo do tradutor público? Existem cursos específicos para a formação desse tipo de tradutor?

T.D.C.: O tradutor público tem um cargo público, mas não é funcionário público. Não é um cargo de provimento, como se diz em serviço público. Só existem duas outras categorias profissionais semelhantes à nossa: os leiloeiros públicos e os fiéis de armazém. São essas três figuras que têm a habilidade profissional testada pelo poder público e a ele prestam serviço, mas não há vínculo empregatício. Não há contrato, não há lotação em algum órgão. O tradutor público, assim como os leiloeiros públicos e os fiéis de armazém são prestadores de serviço e podem trabalhar em qualquer lugar: na sua casa, num escritório. Há o pagamento de impostos também. Quem tem escritório montado paga mais impostos do que quem trabalha em domicílio. Uma outra coisa: não há remuneração vinda dos cofres públicos tampouco. A remuneração é tratada com o cliente. No tocante à demanda do nosso trabalho, quem faz a prospecção de clientes somos nós. A gente só tem que entregar os livros das traduções para a Junta Comercial do estado onde a gente atua. Então, na verdade, é um concurso para fazer a seleção desses profissionais, mas a nossa vida é por nossa conta. Depois do concurso, a gente trabalha como se fosse autônomo.

Lana: Na condição de tradutora juramentada, você faz a chamada "tradução técnica”. Na sua opinião, em que a tradução técnica difere da literária? Caso haja diferença entre esses dois tipos de tradução, essa diferença se reflete no perfil de seus agentes, o tradutor literário e o técnico?

T.D.C.: Sim. Na verdade, na tradução pública, a gente traduz qualquer coisa, qualquer texto que possa vir a ser incluído num processo. Então, é claro que talvez 80\% do nosso trabalho seja de natureza técnica, mas não necessariamente. Eu já traduzi cartas de amor, por exemplo, para um processo de divórcio litigioso, já 
precisei transcrever ligações telefônicas e depois traduzir para um processo de assédio moral. Na tradução pública, tudo é passível de ser traduzido, desde que seja importante para uma ação judicial ou administrativo. Com relação aos dois perfis, o do tradutor técnico e o do tradutor literário, pela minha experiência, eu conheço mais o primeiro. Quanto ao tradutor literário, eu vou falar mais com base na minha observação. O tradutor literário pode ser um escritor. Há muito escritor traduzindo, mas isso não é divulgado, pois é visto como uma atividade secundária, mas, se você observar, grandes nomes da literatura brasileira atuaram como tradutores. E os contemporâneos também traduzem. Rubens Figueiredo, por exemplo, foi um nome que me veio à cabeça. As editoras tratam o tradutor literário, que muitas vezes é escritor, com uma certa deferência diferente da dispensada aos tradutores técnicos pelas editoras que publicam obras técnicas. O tradutor técnico é visto como mais facilmente substituível: se não for esse, poderá ser outro. Isso tudo está ligado à visão que se tem de tradução técnica: um bom domínio da terminologia do campo e um texto claro e objetivo. É isso que é a tradução técnica. Essas são características mais fáceis de encontrar em um profissional. Já o tradutor literário vai ter que ter essas habilidades de quase um escritor literário, se é que já não é. Por outro lado, a tradução técnica também pode ser criativa. Por exemplo, às vezes a gente recebe um texto técnico para traduzir que tem uma qualidade textual ruim. Aí o tradutor tem que ir além do texto, ou seja, tentar entender o que o autor quis dizer e melhorar a qualidade do texto durante a tradução. Tornar um texto originalmente mal escrito num texto traduzido bem escrito requer criatividade. Eu chamo esse lado da tradução técnica de "criativo", ou talvez seja "intelectualmente exigente". O tradutor técnico muitas vezes imprime no texto traduzido uma qualidade inexistente no original. Uma outra coisa: não há muitos cursos para a formação de tradutores técnicos. Os cursos universitários são muito mais voltados para a tradução literária. Isso porque, em muitos dos cursos de graduação voltados para a tradução, são os professores de literatura que dão aula de tradução literária. Puxam a brasa para a sua sardinha. Não existem professores universitários que sejam formados ou mais especialistas em tradução técnica. Podem dar um texto ou outro, mas.. Por exemplo, na UFRJ, que é onde eu atuo, dão até tradução de texto jornalístico, mas ninguém vai fazer um exercício de tradução jurídica, um texto de engenharia, ou voltado para a área de petróleo. É muito raro.

Lana: A tradução literária, depois de concluída, passa por uma revisão, chamada de copidesque ou preparação de originais, com o intuito de retificar eventuais equívocos de tradução e, com isso, aprimorar o texto traduzido A tradução técnica também passa por algum tipo de revisão? Em caso afirmativo, quem é esse revisor?

T.D.C.: Passa, sim. Só que existem duas situações: no escritório, onde existe uma equipe, há a figura do revisor; quem trabalha em casa, não conta com esse agente. $\mathrm{Eu}$, que trabalho em casa, traduzo e reviso as traduções que faço. Depois que traduzo e reviso, eu entrego a tradução diretamente para o cliente. Só que eu também traduzo para empresas. Aí é tradução não juramentada. Certamente existe alguém na empresa que vai mudar alguma coisa que eu tenha escrito, mas eu nem fico sabendo. Às vezes, quando é uma tradução que vai circular num meio 
público, uma tradução feita para um site, por exemplo, eu vejo que há pequenas modificações que foram feitas internamente. Então, tem revisão em texto técnico, sim, e o objetivo é o mesmo: detectar e corrigir erros, equívocos e inadequações, além de saltos e supressões. Em suma, é sempre com a mesma finalidade de tornar o texto legível em português.

Lana: Durante a entrevista a mim concedida em outubro, a tradutora Raquel Zampil disse que o tradutor técnico, por traduzir em cima de modelos já prontos e contar com o auxílio de softwares de tradução, pode ter uma jornada de trabalho diária com expediente fixo. Com o tradutor literário, diferentemente, uma vez que ele lida com uma tradução criativa, por assim dizer, esse cumprimento de expediente não funciona e pode até ser um empecilho à sua criatividade. Você concorda com essa visão?

T.D.C.: Eu não gosto muito de fazer essa divisão tão estanque entre a tradução literária e a tradução técnica. Eu acho que tem técnico no literário e literário no técnico. Então, por isso, eu não gosto muito de pensar assim. Essa questão de o tradutor não estar bem também vai se refletir na tradução de um contrato, por exemplo. Você não vai fazer tão bem quanto num dia em que você está bemdisposto. No campo literário, você pode pegar um romance de tribunal, cheio de linguagem jurídica. Eu me lembro de um caso envolvendo uma colega, que estava traduzindo um best-seller, desses de venda curta, rápida, e cuja ação principal se passava dentro de um avião. $\mathrm{O}$ assassino ou potencial assassino se escondia dentro da casa de máquinas, ou algo assim. Num determinado momento, o autor começou a descrever os motores, as ventoinhas e tal. Quer mais técnico do que isso? Aí, ela teve que parar tudo para pesquisar terminologia, de como o avião funcionava por dentro etc. Afinal, somos passageiros e, portanto, leigos no assunto. Situações como essa, de estar traduzindo uma literatura de massa e, de repente, vir a se deparar com termos técnicos é muito mais comum do que se imagina. E o rigor terminológico precisa ser o mesmo. E por que isso? Não sabemos ao certo quem vai ler aquele romance. Pode ser um engenheiro mecânico que vai detectar um erro terminológico ou pode ser uma dona de casa que não terá esse conhecimento. Por isso, o rigor tem que ser o mesmo, fosse um manual de aviação ou um best-seller, como o caso que estou citando.

Lana: De acordo com informações no site do IBEF-Rio (www.cursosibefrio.org.br), por 10 anos, você lecionou nos cursos de formação de tradutores (graduação e especialização) da PUC-Rio. Atualmente, você continua a atuar nessa área, sendo que na UFRJ. Como é a sua experiência em formar tradutores nessas duas instituições?

T.D.C.: Existe uma diferença grande entre essas duas instituições, porque a PUC tem uma tradição de formar tradutores nos dois níveis, graduação e pósgraduação, lato e stricto sensu. Isso muda muito as coisas. Na graduação da PUC, há a formação de tradutor, é um curso todo voltado para isso. E depois tem a 
especialização. Teve um curso chamado "Formação de Tradutor”, que também era em nível de especialização, ou seja, a PUC tem toda uma gama, um leque grande de formação de tradutor. Já a UFRJ não oferece bacharelado em tradução. O bacharelado de lá é meio sem identidade, excetuando as disciplinas da licenciatura, de prática de ensino e tal. É um bacharelado que recebe muitas críticas por isso e, justamente por essa razão, precisa de uma reforma curricular. Só que lá é tudo muito burocrático. Os alunos criticam muito, porque é um bacharelado sem muito direcionamento. Então, o que acontece lá: nós oferecemos disciplinas de prática de tradução, normalmente no final, quando o aluno já está concluindo o curso, no Francês VIII ou Inglês VIII, quando ele já fez sete períodos da língua e, no oitavo, que é a cereja do bolo, o professor dá prática de tradução. Só que não é um curso de formação de tradutor. A diferença fundamental é que muitos dos meus alunos aqui da PUC eu vi realmente entrando no mercado, o que não acontece na UFRJ. Os alunos da UFRJ que vão entrar no mercado vão ter que buscar qualificação fora do ambiente da universidade, seja na PUC ou em qualquer outro lugar. E isso não é óbvio para eles. Quer dizer, mesmo tendo essas disciplinas no currículo, eles não podem ser vistos como tradutores. No tocante às disciplinas, muitas vezes, os professores de literatura da UFRJ fazem exercícios de tradução, mas para trabalharem o estilo do autor, pois traduzindo os alunos vão perceber muito melhor esse aspecto do que simplesmente lendo. Então, na UFRJ, eu não tenho essa satisfação que eu tive aqui de ver que alunos saíram deste ambiente universitário e, de fato, entraram para o mercado, tornaram-se profissionais da área editorial, de tradução de games também, como o Michel em cuja banca eu estava hoje. Enfim, o curso da PUC leva o aluno realmente para o mercado de trabalho, o que não acontece na UFRJ. O aluno da UFRJ que quer buscar inserção no mercado de trabalho precisa fazer muita coisa além da graduação e muitos deles não fazem isso.

Lana: Nos cursos de formação de tradutores (graduação e especialização) oferecidos por essas duas instituições, as disciplinas contemplam todo tipo de tradução ou mais especificamente a literária?

T.D.C.: O curso da PUC, mesmo o da graduação, tem a preocupação de oferecer um leque bem amplo das possibilidades do mercado. É claro que isso vai depender do corpo docente, mas existe essa preocupação, sim, de mostrar o que se faz em termos de tradução. Há eletivas sobre legendagem, tradução jurídica, por exemplo, mas são eletivas que se tornam obrigatórias, porque é a oferta que há ali no momento em termos daquela modalidade de tradução.

Lana: A tecnologia está presente em todas as áreas do conhecimento e a tradução não é exceção. Há disciplinas voltadas para as tecnologias da tradução na PUCRio e na UFRJ?

T.D.C.: Aqui na PUC, existe, sim, uma disciplina específica, de tecnologias aplicadas à tradução, que ensina a lidar com isso. Os professores variam, vários professores já passaram por essa disciplina. Agora, na UFRJ, não. O que pode acontecer lá é que algum professor poderá incluir alguma vivência com memória 
de tradução nas suas áreas, mas não está formalmente expresso na ementa da disciplina que isso seja feito. É uma coisa que não é formalizada e vai depender de o professor incluir. Aqui essa formalização existe, sim. Está na ementa e, portanto, precisa ser cumprido.

Lana: Quem é o aluno dos cursos de formação de tradutores, o tradutor já inserido no mercado de trabalho, que já traz consigo uma vivência tradutória, por assim dizer, ou o entusiasta da tradução em busca da qualificação necessária para se lançar no mercado editorial?

T.D.C.: Depende. Na graduação, eu acho que é o entusiasta em busca de qualificação. É o jovem que ainda não tem experiência com tradução. A maior parte não tem essa experiência e vai começar a trabalhar durante a graduação. Vai fazer estágios e aí começa a se inserir no mercado. Muitos chegam ao final da graduação já trabalhando, mas começam o curso bem crus mesmo. Já na especialização, tem de tudo. Tanto o profissional que já trabalha e quer se aprimorar, quanto aquele que nunca trabalhou e quer experimentar. Tem aquele que trabalha com tradução esporadicamente e quer abraçar a tradução como uma segunda atividade, ou seja, tem uma certa experiência, mas nem tanta assim. Enfim, na especialização, a gente tem uma gama vasta de perfis de alunos, com históricos diferentes.

Lana: Há algum tipo de "programa de parceria" entre essas duas universidades e as editoras (independentemente do tipo de publicação) que tenha por objetivo fornecer mão de obra qualificada para a atividade tradutória?

T.D.C.: Às vezes esse canal não é tão formal, muito institucionalizado, quero dizer. Há as parcerias para estágios. 


\section{ANEXO O \\ Entrevista com a tradutora e professora Lourdes Sette (05 de \\ dezembro de 2018)}

Lana: Como está estruturado o concurso da PUC que é voltado para a formação de tradutores?

L. Sette: O curso da PUC voltado para a formação de tradutores está estruturado em módulos numa progressão de complexidade de tradução. Não que a gente consiga, na realidade, estabelecer o que é fácil e o que é difícil em tradução. Eu digo e afirmo que não há nada fácil de ser traduzido. Até mesmo I love you pode não ser simplesmente "Eu amo você". Tudo vai depender do contexto. Para você ver até onde eu chego. Não se pode achar que é tudo fácil, que está dado. Tudo tem que ser olhado com muito cuidado. Quando eu falo de dificuldade ou de complexidade em tradução, é porque o primeiro módulo, por exemplo, é Introdução à Tradução e Ferramentas de Tradução, em que a gente trabalha com textos pequenos, que não envolvem pesquisas muito grandes. É nesse aspecto que eu classifico o que eu chamo de complexidade de tradução. Como são aulas no período da manhã e no da tarde, em um deles, nós oferecemos também aulas sobre as ferramentas de tradução, pois entendemos que precisamos ajudar o aluno a se familiarizar com softwares utilizados em tradução e também aprender a pesquisar em tradução. De um modo geral, sabemos ir para a internet pesquisar, mas nós temos uma professora, a Adriana Rieche, que ensina como lidar com essas ferramentas. Depois, vamos aprofundar aspectos vistos na introdução: tradução de não ficção, tradução técnico-científica, vemos também Estudos da Tradução, um pouco de versão, este com uma carga horária mais reduzida, porque o curso é de tradução e não de versão, tradução jurídica, terminologia, com a Prof ${ }^{\mathrm{a}}$ Janine Pimentel, da UFRJ. Além disso, temos um painel de mercado (é apenas uma aula), em que professores, como a Rebecca Atkinson e a Paula Diniz, dão dicas para os alunos de como, por exemplo, abrir uma firma, como entrar em contato com editoras, enfim, como entrar no mercado. Temos também Elaboração de monografia, que são duas aulas, com a Prof ${ }^{a}$ Liana Biar, que ministra essa disciplina também para as turmas de literatura.

Lana: O que contempla a tradução de não ficção?

L. Sette: Na tradução de não ficção, nós trabalhamos com biografias, textos jornalísticos, embora a linha entre a ficção e a não ficção seja meio tênue. Na outra ponta temos a ficção avançada, em que se inclui um pouco de poesia, que é com o Paulo Britto, os clássicos (retradução), enfim, são textos literários de maior complexidade. Hoje quem está ministrando esse curso de ficção avançada é a Prof ${ }^{\text {a }}$ Sônia Moreira. Também oferecemos tradução empresarial, que é a tradução de contratos, de material corporativo de um modo geral. A tradução empresarial, para o ano de 2019, foi incluída no guarda-chuva da tradução técnico-científica. Temos dois módulos de português, que é importantíssimo, e também tradução de informática. 
Lana: Pela descrição que você está me dando da grade de disciplinas, o curso de especialização em tradução que a PUC oferece uma abordagem bastante pragmática, ou seja, o curso de especialização da PUC está voltado mormente para se fazer a tradução e nem tanto para se refletir sobre a tradução. Confere?

L. Sette: Sim, bem pragmática, mas nós não só ensinamos a fazer a tradução. Nós refletimos sobre a tradução também. Aliás, esse é um diferencial do nosso curso. Todos os professores do curso, à exceção da Janine Pimentel, foram formados pela PUC. Então, aqui, o aluno aprende não só a traduzir, mas também a refletir sobre o que ele está fazendo. O aluno é orientado a pensar sobre as dificuldades que enfrentou durante uma tradução, onde pesquisou, as estratégias, as técnicas que usou. Essa sempre foi a tônica do curso aqui. Eu digo isso como professora e como ex-aluna. Eu fui aluna da Márcia, do Paulo, da Maria Paula, que foi minha orientadora. Todos os professores da PUC levam para a sala de aula a reflexão sobre a tradução. Há teoria na especialização também, inclusive, a disciplina de Estudos da Tradução sou eu que dou. É nessa disciplina que se estuda a história da tradução, as principais abordagens, os principais teóricos dos Estudos da Tradução, sobretudo os brasileiros. Eu e a Marcia damos muito enfoque aos teóricos brasileiros.

Lana: Quem é o aluno da especialização da PUC: o tradutor já inserido no mercado que traz consigo uma vivência tradutória, digamos assim, ou é o entusiasta da tradução que está em busca de qualificação para se inserir no mercado?

L. Sette: Eu diria que são esses dois e muitos outros. Muitos dos alunos que buscam a especialização da PUC já traduzem, já estão inseridos no mercado de trabalho, mas vêm em busca de respostas para perguntas que vêm fazendo ao longo da carreira. Em suma, vêm para verificar se o que eles estão fazendo é o certo. Ele já traduz, mas sente que precisa de uma formação. Outros não estão traduzindo, mas querem aprender e vêm em busca dessa formação. O terceiro grupo de alunos é mais heterogêneo: há quem queira mudar de profissão, quem queira ocupar o tempo e até quem venha para arrumar casamento. Acredite. Quando eu vou ver o currículo do candidato a uma vaga na especialização, o que eu observo com mais atenção são as habilidades dele, com atenção especial para formação em inglês. Às vezes é necessário aplicar uma prova, mas, se o candidato tem um certificado de proficiência, é claro que é dispensado de fazer a prova. Eu também peço para fazer uma carta de intenção para ver como está o português, quer dizer, é necessário saber quem é esse aluno que está chegando. Na hora da entrevista, por exemplo, eu quero sentir o quanto aquele candidato tem vontade de estar ali.

Lana: Há algum tipo de parceria entre a PUC e as editoras?

L. Sette: Uma parceria propriamente, não, mas nós conhecemos um monte de gente em editora. Aí, nós ligamos para dizer que temos um aluno muito bom e perguntamos se estão precisando de tradutor. Às vezes, são os editores que ligam 
para a gente. Como o cenário, no momento, para o mercado editorial está muito ruim, isso não tem acontecido. E o que nós temos feito? Temos convidado pessoal de editora (editores, revisores) para virem à PUC falar sobre suas atividades. Não é a porta que gostaríamos de abrir, mas é uma janela.

Lana: Pesquisando na internet, eu vi que você atua como tradutora desde 1987 e que a conclusão da sua especialização data de 1997. Ou seja, quando você terminou o seu curso, você já trazia consigo uma bagagem de 10 anos de experiência em tradução. Como você compararia a Lourdes tradutora de antes e a de depois da especialização?

L. Sette: Para responder a essa pergunta, eu vou dar um passo atrás. Entrei aqui para fazer o curso de formação de tradutor. Trabalhei como secretária durante quinze anos. Em 1989, eu trabalhava numa multinacional que confeccionava cartão de crédito. Era uma gráfica de segurança que, além de cartões de crédito, confeccionava também vale-transporte, vale-refeição. Era uma empresa inglesa, que depois foi vendida para uma americana. Aí, o pessoal começou a ver que eu sabia traduzir. Eu era a secretária do Presidente, que vivia viajando. Havia um advogado lá que não sabia uma palavra de inglês, mas que precisava participar das reuniões, todas em inglês. Ele, então, me pediu para que eu assistisse às reuniões e dissesse a ele o que estava sendo dito. E foi quando ele começou a me dar coisas para traduzir. Nesse meu começo, a única pesquisa que eu fazia era em dicionário. Eu não tinha a menor noção de que a coisa era muito maior, que ia além da língua. Por questões familiares, eu precisei parar de trabalhar. Só que o tal advogado ainda precisava que eu traduzisse para ele. Como é uma atividade que se faz em casa (home office), eu aceitei. Foi por intermédio dele que eu tomei conhecimento do curso da PUC. Ele sugeriu que eu me aprimorasse para abrir uma firma de tradução. Agora, respondendo à sua pergunta, eu não sei o que eu fazia antes do curso da PUC, mas uma coisa eu garanto: não era traduzir. Eu não tinha ideia do que envolvia a tradução. Eu não sabia o quanto eu podia me afastar ou me aproximar do texto fonte e essa noção, essa sensibilidade, é fundamental. Agora, eu conheço tradutores que nunca fizeram curso de nada, não conhecem uma teoria, mas que são brilhantes. São raros, mas existem.

Lana: Quando você fala em "refletir sobre a tradução", o que você quer dizer exatamente?

L. Sette: Quando você recebe um texto para traduzir, você precisa saber a que público aquele texto se destina, em que contexto esse texto está inserido. Por exemplo, é um texto de uma empresa. Você precisa saber o que a empresa pretende com aquele texto. Será que existe um glossário de que constem termos comumente usados naquele meio? Por exemplo, em tradução de textos jurídicos, a recomendação de praxe era não mexer em nenhuma vírgula, esteja ela errada ou não. Isso porque o chamado "juridiquês” tem uma sintaxe própria e a mudança de uma vírgula poderia mudar todo o sentido. Refletir sobre o texto a ser traduzido é pensar na sua materialidade. Outra coisa são os paratextos. Quando eu recebo um livro para traduzir, a primeira coisa que eu faço é ler os paratextos: ver quem é o 
autor, quantos e quais livros publicou, quem os traduziu, que termos usa, se tem uma marca vocabular, discursiva, característica. Então, tudo isso precisa ser observado pelo tradutor. $O$ tradutor precisa ter essa sensibilidade, ser um leitor obsessivo.

Lana: Na condição de tradutora experiente, com serviços prestados a muitas editoras, como essas empresas selecionam os seus tradutores? O que esperam desses profissionais e como classificam uma boa tradução?

L. Sette: O primeiro livro que eu traduzi foi por indicação da Maria Paula. Foi para a Editora Imago. Traduzi muitos anos para eles. O que eles recomendavam era que o texto traduzido deveria ter uma linguagem adequada ao público alvo. $\mathrm{O}$ leitor não pode ler tendo a sensação de que aquele texto não foi escrito em português. Isso vai de encontro a algumas teorias que dizem que a tão desejada fluência do texto traduzido faz o tradutor invisível. Só que a gente quer trabalhar e continuar recebendo tradução. Para isso, precisa atender às expectativas do cliente, no caso, as editoras. Por outro lado, ler um texto com palavras estrangeiras no meio me irrita. Se, pelo contexto, eu consigo entender, tudo bem, mas, se não, e com isso eu tiver que ir para a internet pesquisar, já quebra o ritmo. $\mathrm{O}$ tradutor precisa ter a sensibilidade de pesar isso. Por exemplo, um romance em inglês, mas que o personagem falou uma frase em francês. Aí, você mantém o francês em itálico. Tudo bem. Agora, deixar de propósito para que o leitor saiba que está lendo uma tradução, eu não concordo.

Lana: Considerando que o livro traduzido é um produto comercial e que sua confecção precisa ser cuidada, você saberia dizer se as editoras, de um modo geral, agrupam os tradutores por gênero?

L. Sette: Totalmente. E também pela formação acadêmica. Por causa da minha primeira graduação, que foi em psicologia, as editoras me davam para traduzir tudo que era livro que falava sobre sexo. Se você jogar o meu nome na internet, você vai ver lá: tradutora de O livro do orgasmo, Cinquenta tons de êxtase. Mas o engraçado é que eles não me dão muito livro sobre psicologia e psicanálise. Durante todos esses anos atuando como tradutora só traduzi dois livros da área. Só me dão livro que fala de sexo. Agora, vou lhe dizer: não é fácil traduzir livro sobre sexo, não. É porque há uma linha tênue entre a vulgaridade e a sensualidade. Esse Cinquenta tons de êxtase, que eu traduzi, saiu na linha de Cinquenta tons de cinza.

Lana: Na sua visão, até que ponto o tradutor é responsável por uma tradução publicada, levando-se em conta a atuação de outros agentes, como editores e revisores?

L. Sette: Eu nem sei dizer assim uma porcentagem exatamente, porque há uma briga eterna entre tradutores e revisores. Acho que isso tinha que acabar e a gente trabalhar em conjunto. Inclusive, o revisor ganha infinitamente menos do que o 
tradutor, enquanto que eu acho que deveria ganhar tanto quanto. O revisor ganha uma miséria, considerando o trabalho que tem. Eu acho que deveria ser assim: o editor já escolhe a dupla de tradutor e revisor que vai trabalhar em conjunto. Tudo bem que o tradutor ganhe mais porque é sempre bilíngue e que é ele que vai pesquisar para traduzir. Eu diria que, por lauda, o tradutor ganharia, digamos, 50 reais, e o revisor, 20. Outra coisa também que eu vejo muito por aí é o tradutor jogar a responsabilidade da pesquisa para cima do revisor. Está errado. Isso é tarefa do tradutor. Mas também existe o outro lado: às vezes, o revisor quer mostrar serviço e mexe em coisa que não tem que mexer. Eu tive dois problemas na minha carreira. Um foi um livro de psicanálise. Existem termos que se usam em psicanálise. Aí, eu escrevi no email que era para deixar aquele termo assim, porque é o jargão. Mesmo assim, mexeram. O outro foi um termo que se usa em guerra. Não me lembro exatamente qual foi. Eu sinalizei, mas, mesmo assim, mexeram também. É uma coisa sobre a qual o tradutor não tem controle. Embora seja o mesmo processo, são atividades diferentes executadas por agentes diferentes. É a sua assinatura, é o seu rosto que aparece, mas nem sempre o texto é $100 \%$ seu.

Lana: Com as redes sociais, leitores comuns têm acesso aos tradutores das obras de seus autores favoritos. Como você vê essa interação entre tradutor e público?

L. Sette: Vejo da melhor maneira possível! É um sonho! A gente quer visibilidade. Só que essa visibilidade não é exatamente por vaidade. É porque a tradução é uma atividade importantíssima. Seja que gênero for que estiver sendo traduzido, o tradutor tem que estar sempre muito atento. Não é porque é um livro de ficção, por exemplo, que eu vou colocar qualquer coisa. O texto não é meu. Não é uma folha em branco que eu recebi para colocar qualquer coisa. É o texto que alguém criou e que o tradutor recebe a incumbência de reescrever numa outra língua. É necessário que o leitor saiba que existe uma pessoa que se debruçou sobre aquele texto fonte para reescrevê-lo na língua alvo. O leitor precisa saber que o tradutor é ético, que não vai mudar o que o autor escreveu, que o texto que está sendo lido lá nos Estados Unidos, por exemplo, é o mesmo que será lido aqui no Brasil. O tradutor não é o autor para sair mudando o texto original como lhe convém. Se o tradutor quer criar, então que produza um texto autoral. Eu escrevi um artigo sobre isso. Eu adoro trabalhar no texto alheio. 